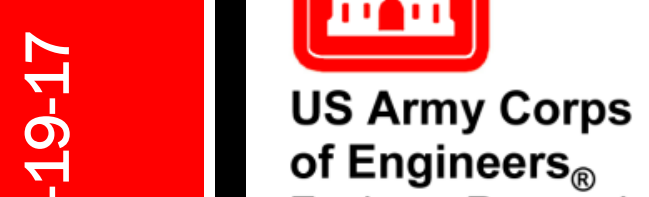

\title{
ERDC
}

Engineer Research and

Development Center

ERDC 6.2 Boreal Aspects of Ensured Maneuver (BAEM)

Assessment of Field Methods for Measuring Mechanical Properties of Snow

Sally A. Shoop, Wendy L. Wieder, Bruce C. Elder,

August 2019

Samuel A. Beal, and Elias J. Deeb

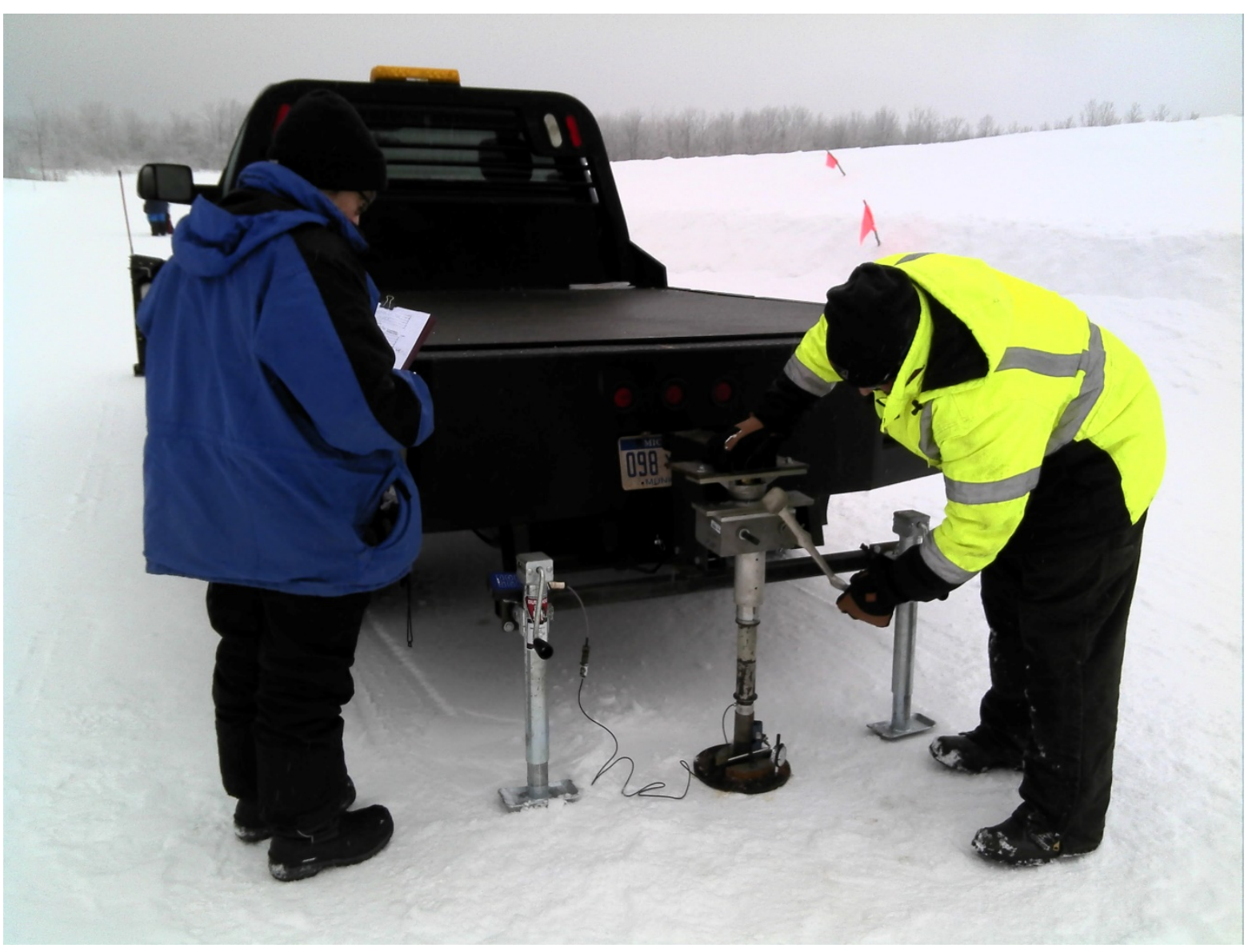


The U.S. Army Engineer Research and Development Center (ERDC) solves the nation's toughest engineering and environmental challenges. ERDC develops innovative solutions in civil and military engineering, geospatial sciences, water resources, and environmental sciences for the Army, the Department of Defense, civilian agencies, and our nation's public good. Find out more at www.erdc.usace.army.mil.

To search for other technical reports published by ERDC, visit the ERDC online library at http://acwc.sdp.sirsi.net/client/default. 


\section{Assessment of Field Methods for Measuring Mechanical Properties of Snow}

Sally A. Shoop, Wendy L. Wieder, Bruce C. Elder, Samuel A. Beal, and Elias J. Deeb U.S. Army Engineer Research and Development Center (ERDC) Cold Regions Research and Engineering Laboratory (CRREL) 72 Lyme Road

Hanover, NH 03755-1290

Final Report

Approved for public release; distribution is unlimited.

Prepared for Assistant Secretary of the Army for Acquisition, Logistics, and Technology 103 Army Pentagon

Washington, DC 20314-1000

Under Project 465395, ERDC 6.2 "Boreal Aspects of Ensured Maneuver (BAEM)" and Project 471941, "Remote Assessment of Snow Mechanical Properties" and "Mobility in Peat and Northern Soils" 


\section{Abstract}

Winter climates present a variety of surfaces that challenge vehicle mobility. Surfaces range from soft, virgin snow, to groomed snow and ice. This study evaluated the capabilities of various testing devices to measure the mechanical properties of winter surfaces. Concurrent satellite imagery supplemented in situ physical testing. The goals were (1) to find tests that most practically evaluate these winter surfaces for vehicle mobility and (2) to determine if imagery analysis correlates with mechanical properties, thus potentially allowing remote assessment of snow physical and mechanical characteristics.

The test methods were typically useful for either virgin snow or groomed snow; no method worked well on all surfaces. Correlations between test devices were generally poor, but there were some important trends identified between (1) tests that measure the near-surface snow strength, (2) tests best suited for stronger snow, (3) the Clegg Impact Hammers and California Bearing Ratio, and (4) the optical imagery and surface drop cones. This study provides a rich dataset for assessing the current state of the art and future research needs for measurement and remote assessment of snow mechanical properties for vehicle mobility prediction.

DISCLAIMER: The contents of this report are not to be used for advertising, publication, or promotional purposes. Citation of trade names does not constitute an official endorsement or approval of the use of such commercial products. All product names and trademarks cited are the property of their respective owners. The findings of this report are not to be construed as an official Department of the Army position unless so designated by other authorized documents. 


\section{Contents}
Abstract
it

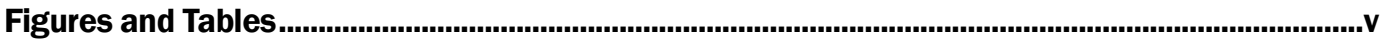

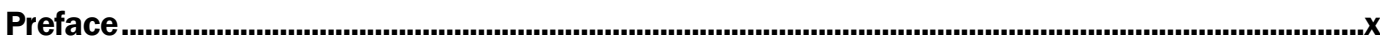

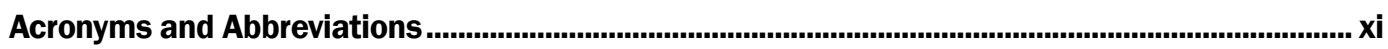
Unit Conversion Factors ...................................................................................................................... xiii

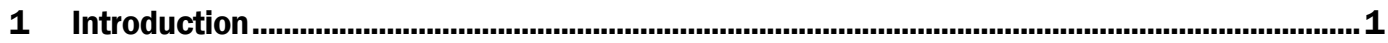

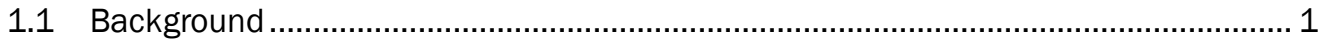

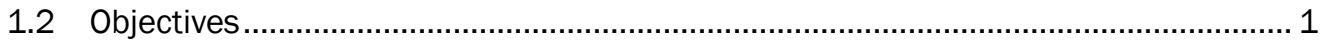

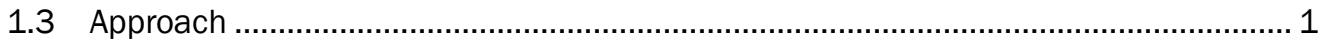

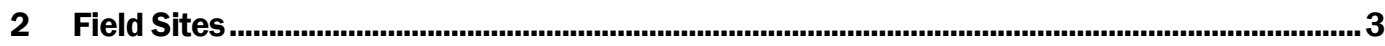

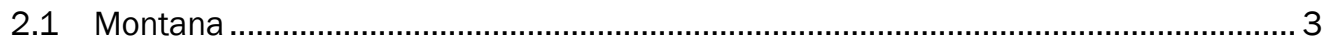

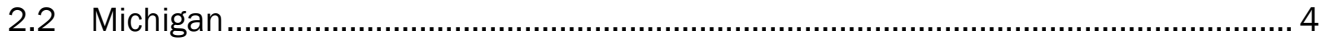

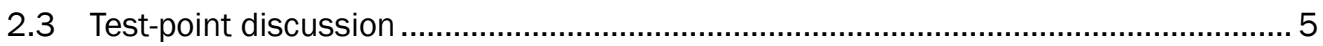

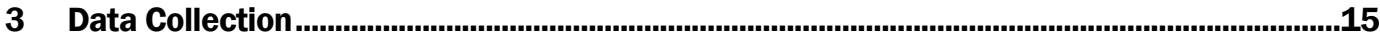

3.1 Mechanical measurements for groomed snow............................................... 16

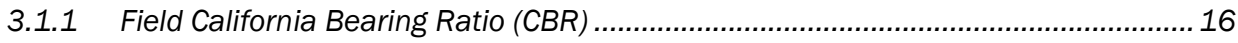

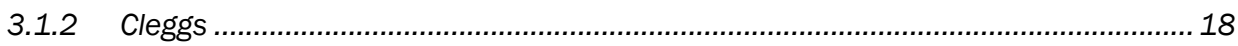

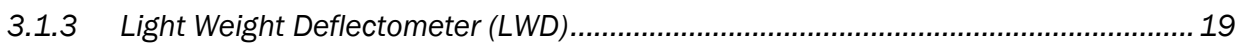

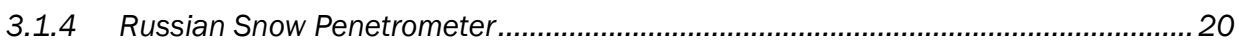

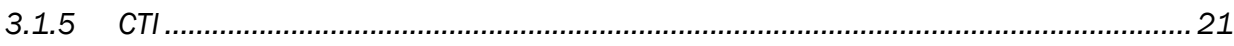

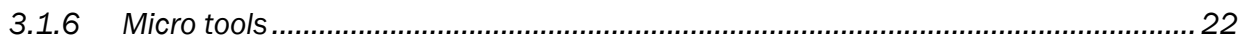

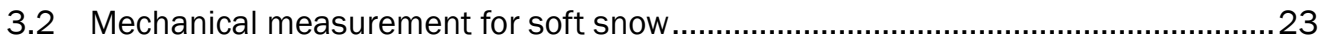

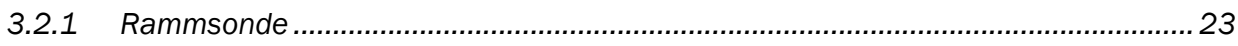

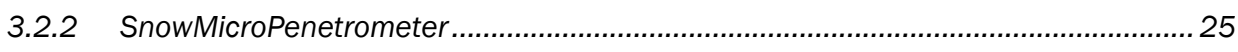

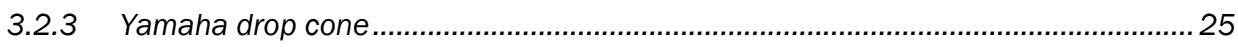

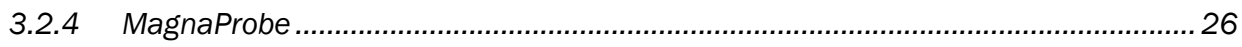

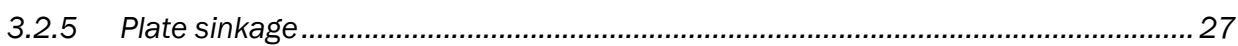

3.3 Additional physical and optical measurements .................................................. 28

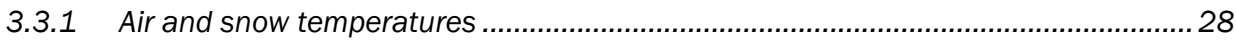

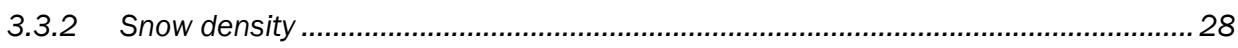

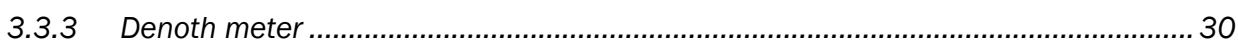

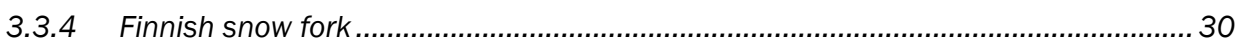

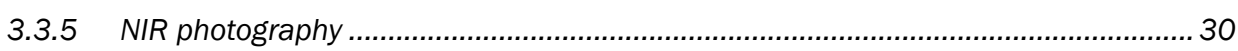

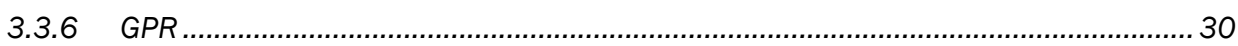

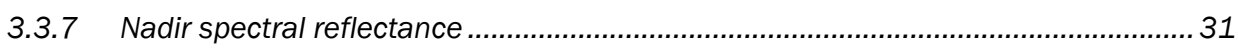

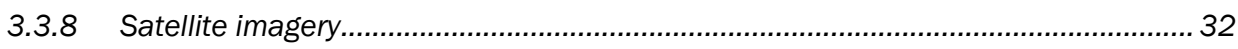

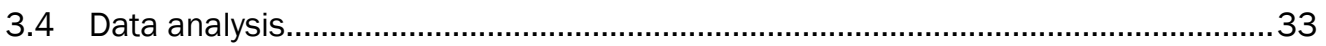




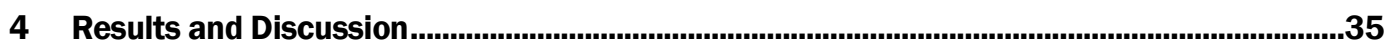

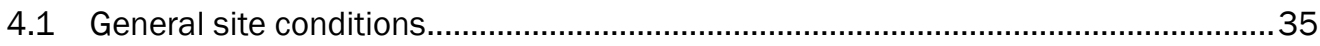

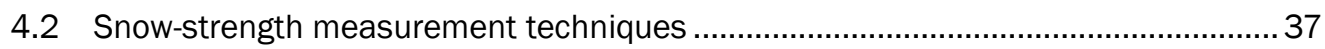

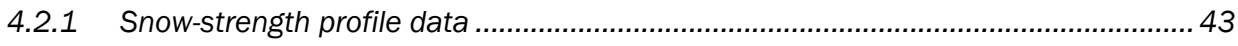

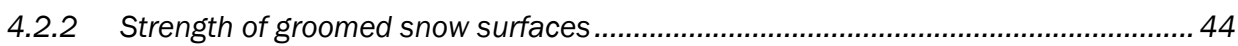

4.2.3 Correlation between strength measurements....................................................4 47

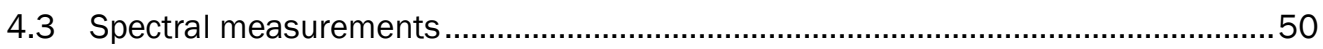

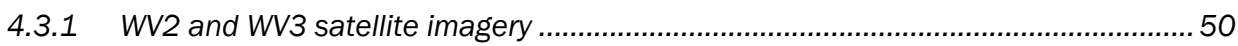

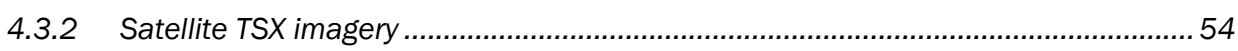

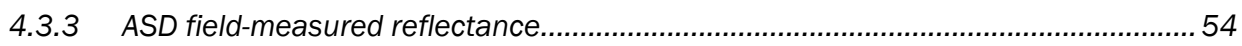

4.4 Comparison of strength measurements with spectra data....................................59

5 Conclusions and Recommendations for Future Work.....................................................60

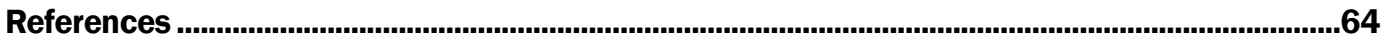

Appendix A: Additional Site Imagery .................................................................................68

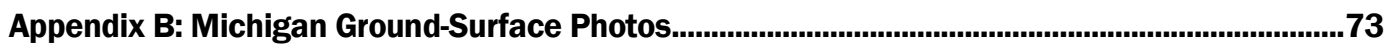

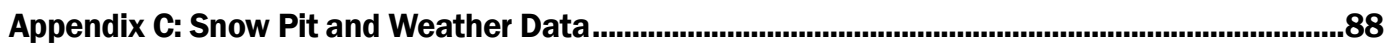

Appendix D: Summary of Snow Measurements by Site ................................................................ 104

Appendix E: Comparison of Snow Moisture and Density Measurement Techniques

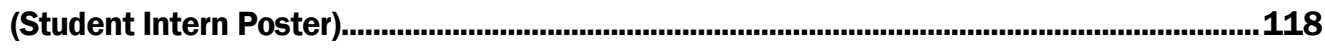

Appendix F: WV2 and WV3 Data Concurrent with Michigan Field Campaign ...........................120

Appendix G: Surface-Condition Photos and Michigan Cloud-Cover Photos for Field

Spectrometer (ASD) Data Collection .................................................................................124

Report Documentation Page 


\section{Figures and Tables}

\section{Figures}

1 Montana test site at West Yellowstone Airport

2 Montana test points superimposed over winter imagery taken during the field campaign

3 Schematic of the Michigan test site

4 Michigan test points superimposed on imagery from summer to show to show ground surfaces

$5 \quad$ Michigan test points superimposed on winter imagery...................................................14

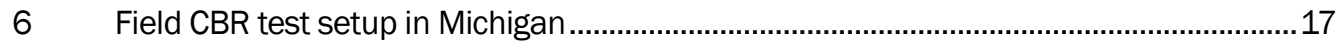

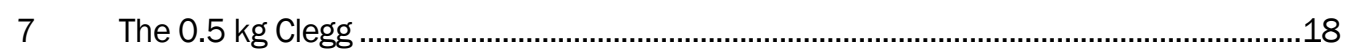

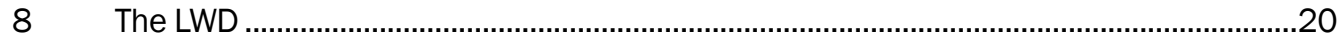

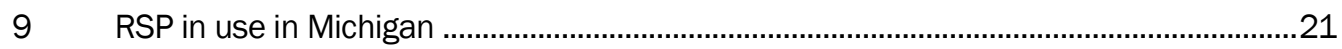

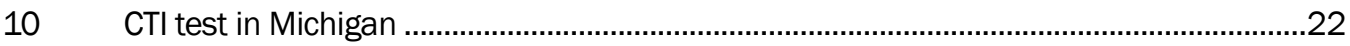

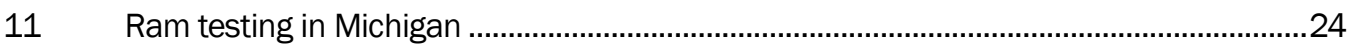

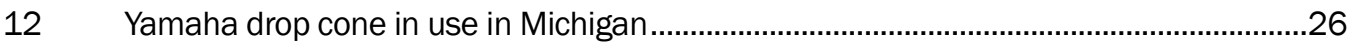

13 Yamaha drop cone schematic and specifications............................................................26

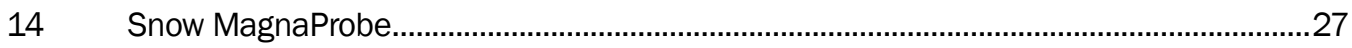

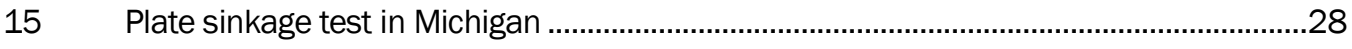

16 Snow-density-sample extraction in a snow pit....................................................................29

17 Snow-density test using the aluminum cylinder in Michigan..........................................29

18 ASD taking a datum measurement in Michigan ..............................................................31

19 Snow depth and type by site in Michigan ...........................................................................35

$20 \quad$ Snow depth by site in Montana.........................................................................................35

21 Finnish fork density and moisture compared to sample density and Denoth moisture in different snow pits ...........................................................................36

22 NIR photo (top) and standard photo (bottom) of Montana snow pits walls......................37

23 Boxplots of each snow-strength measurement technique by study area for the Michigan site.

24 Boxplots of each snow-strength measurement technique by study area at the Montana site

25 Boxplots of each snow-strength measurement technique by surface type in Michigan. The $p$-values are for Kruskal-Wallis analysis of variance

26 Boxplots of each snow-strength measurement technique by surface type for Montana. The $p$-values are for Kruskal-Wallis analysis of variance...

27 RSP hardness profiles from Michigan ..............................................................................43

28 SMP profile from virgin snow in Montana........................................................................44

29 Measured CBR by site in Michigan..........................................................................................45

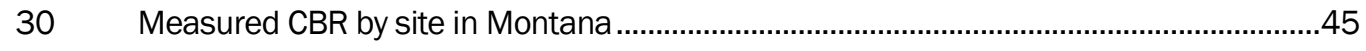

31 Mean site surface CBR calculated from $2.25 \mathrm{~kg}$ Clegg Impact Values in 
Michigan. Error bars are \pm one standard deviation

32 Mean site surface CBR calculated from $2.25 \mathrm{~kg}$ Clegg Impact Values in

Montana. Error bars are \pm one standard deviation

33 Spearman correlation matrix of measured snow properties with $n>1$ comparative observations. LWD ISM values listed are representative (averages are nearly identical). The $p$-values are indicated as * $<0.1$, $* *<0.05$, and $* * *<0.01$

34 CIV versus field CBR

35 CTI versus $0.5 \mathrm{~kg}$ Clegg CIV

37 WV2/WV3 reflectance spectra for each Michigan study area. Each line represents a site. The colors relate to the type of surface.

38 Michigan WorldView reflectance spectra averaged by surface type .54

39 ASD field spectrometer reflectance subsampled into the eight WV2 bands for asphalt, groomed snow, ice, and virgin snow surfaces in Michigan

40 Michigan ASD field spectrometer reflectance subsampled into the WV3 bands. Red lines are for asphalt, purple for ice, blue for groomed snow, and green for virgin snow. The panchromatic band is 450 to $800 \mathrm{~nm}$

41 Full spectra of the Michigan ASD reflectance from the virgin snow measurements

42 Michigan ASD field spectrometer reflectance values for asphalt (red), ice (purple), groomed snow (blue), and virgin snow (green) surfaces.

43 Michigan ASD field spectrometer reflectance values for 800-1200 nm, for asphalt (red), ice (purple), groomed snow (blue), and virgin snow (green) surfaces.

$44 \quad$ Michigan groomed snow (red) falls within the scatter of the undisturbed snow (various greens)

45 Plots of significant $(p<0.01)$ Spearman correlations between Michigan WV2 MS1 spectral band ( $400-450 \mathrm{~nm})$ and snow strength measured with the CTI and Yamaha drop cone

A-1 West Yellowstone Airport central runway, taxiway, and ice lane test points as they relate to the airport pavement surfaces

A-2 Michigan Spin Up Pads 1 and 2 test points

A-3 Michigan Spin Up Pads 1 and 2 test points winter imagery

A-4 Michigan Spin Up Pad 3, Loop 1, Vehicle Dynamics Area 2, and the 900 and $300 \mathrm{ft}$ circles test points

A-5 Michigan Spin Up Pad 3, Loop 1, Vehicle Dynamics Area 2, and the 900 and $300 \mathrm{ft}$ circles test points winter imagery

A-6 Michigan Ice Rink and Sweeper parking pad test points ...............................................70

A-7 Michigan Ice Rink and Sweeper parking pad test points winter imagery ..........................71

A-8 Michigan Loop 3, Stability Area, and Loop 4 test points .................................................... 71

A-9 Michigan Loop 3, Stability Area, and Loop 4 test points winter imagery ...........................72

B-1 Spin Up Pad 2 (points 19SU2_A through F, 21SU2, 22SU2). Note that the bottom photo looks out into the wooded area of points 19SU2VS_A through $\mathrm{E}$. 
B-2 Loop 1 washed gravel road (points 20LP1WG_1 through 3) ........................................ 74

B-3 Loop 1 grass-surfaced road (points 20LP1GS_4 through 6) …………………………...75

B-4 Gravel pad (points 20GPVS and 21GPVS) ………………………….........................76

B-5 Sweeper parking pad (points 21SPW_1 through 3) ………..........................................77

B-6 Ice slope: entire slope (top), steep slope area (middle) (point 21IS_S), and lower slope area (bottom) (point 21IS_L) .......................................................................78

B-7 Spin Up Pad 1 (points 21SU1_1 and 2) ................................................................

B-8 Gravel road adjacent to the gravel pad, part of Loop 1 (point 22GPRD_1

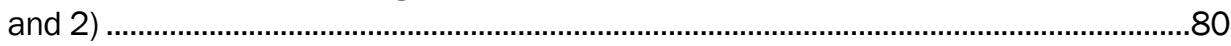

B-9 Spin Up Pad 3 (points SU3_1 through 3) ................................................................ 81

B-10 Terrain north of Spin Up Pad 3 (points 22SU3VS_1 through 6).....................................82

B-11 Ice Rink area (points 22IR_S and 22IR_I) ................................................................83

B-12 Stability Test Area (points 22STAB_S and 22SATB_Gl) .................................................84

B-13 Vehicle Dynamics Area 2 (points 22VDA2_1 and 2)..................................................

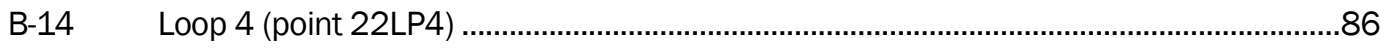

B-15 Terrain off Loop 4 (point 22LP4VS) ........................................................................... 87

C-1 Snow-pit density, temperature, and snow moisture profiles for the two snow pits at Montana test point 27RWYS, 27 January 2018.

C-2 Snow-pit density, temperature, and snow moisture profiles for the snow pit at Montana test point 27TWYS, 27 January 2018.

C-3 Snow-pit density, temperature, and snow moisture profiles for the snow pit at Montana test point 28MLPW, 28 January 2018 .90

C-4 Snow-pit density, temperature, and snow moisture profiles for the snow pit at Montana test point 27TWYS, 29 January 2018

C-5 Snow-pit density, temperature, and snow moisture profiles for the snow pit at Montana test point 27RWYS, 29 January $2018 .$.

C-6 Snow-pit density, temperature, and snow moisture profiles for the snow pit at Montana test point 27RWYS, 30 January 2018

C-7 Snow-pit density, temperature, and snow moisture profiles for the snow pit at Montana test point 30MLPN, 30 January 2018.

C-8 Snow-pit density, temperature, and snow moisture profiles for the snow pit at Montana test point 27RWYS, 31 January 2018

C-9 Snow-pit density, temperature, and snow moisture profiles for the snow pit at Michigan test point 19SU2VS_A, 19 February 2018.

C-10 Snow-pit density, temperature, and snow moisture profiles for the snow pit at Michigan test point 19SU2VS_E, 19 February 2018

C-11 Snow-pit density, temperature, and snow moisture profiles for the snow pit at Michigan test point 20GPVS, 20 February 2018

C-12 Snow-pit density, temperature, and snow moisture profiles for the snow pit at Michigan test point 21IS_S, 21 February 2018

C-13 Snow-pit density, temperature, and snow moisture profiles for the snow pit at Michigan test point 21IS_L, 21 February 2018

C-14 Snow-pit density, temperature, and snow moisture profiles for the snow pit at Michigan test point 22SU3VS, 21 February 2018 
C-15 Snow-pit density, temperature, and snow moisture profiles for the snow pit at Michigan test point 23HQP, 23 February 2018 ………..............................................96

C-16 Montana meteorological data for 24 January 2018 ........................................................97

C-17 Montana meteorological data for 25 January 2018 ……................................................97

C-18 Montana meteorological data for 26 January 2018 ........................................................98

C-19 Montana meteorological data for 27 January 2018 …….............................................98

C-20 Montana meteorological data for 28 January 2018 ....................................................99

C-21 Montana meteorological data for 29 January 2018 ......................................................99

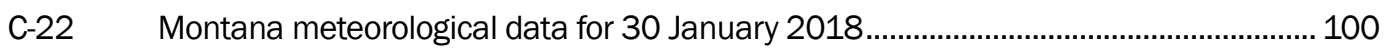

C-23 Montana meteorological data for 31 January 2018 …................................................ 100

C-24 Michigan meteorological data for 18 February 2018 ................................................ 101

C-25 Michigan meteorological data for 19 February 2018 …............................................. 101

C-26 Michigan meteorological data for 20 February 2018 …….......................................... 102

C-27 Michigan meteorological data for 21 February 2018 ……......................................... 102

C-28 Michigan meteorological data for 22 February 2018 ................................................... 103

C-29 Michigan meteorological data for 23 February 2018 …………………….................. 103

F-1 WorldView-2 reflectance spectra averaged by study area .............................................. 120

F-2 WorldView-2 reflectance spectra averaged by subgrade .............................................. 120

F-3 WorldView-3 reflectance spectra averaged by study area ............................................. 121

F-4 WorldView-3 reflectance spectra averaged by snow surface type................................ 121

F-5 WorldView-3 reflectance spectra averaged by subgrade .............................................. 121

F-6 Plots of significant $(p<0.01)$ Spearman correlations between WorldView2 multispectral bands (MS1-MS8) and snow strength measurements, with linear regression models (Michigan data set) ........................................................ 123

G-1 Montana ice lane (Montana point 28IL) ...................................................................... 124

G-2 Asphalt concrete pavement at Ice Rink (Michigan point 22IR_AC) both wet and dry conditions ........................................................................................................ 125

G-3 Michigan groomed snow points 22SU3 (top) and 22SU2 (bottom) ............................. 126

G-4 Michigan smooth ice surface point 22IR_I (top) and grooved ice surface point 22STAB_Gl (bottom) …………….................................................................... 127

G-5 Michigan rutted snow surface point 22900C (top) and tracked snow surface point 22LP3NW (bottom) ............................................................................ 128

G-6 Michigan virgin snow points 22SU3VS (top) and 22300CVS (bottom)......................... 129

G-7 Cirrostratus cloud cover at the beginning of ASD testing (9:43 local time) ................... 130

G-8 Cirrostratus and altostratus cloud cover at noon during ASD testing............................. 130

G-9 Altocumulus cloud cover at the end ASD testing ( 16:30 local time) .......................... 131

\section{Tables}

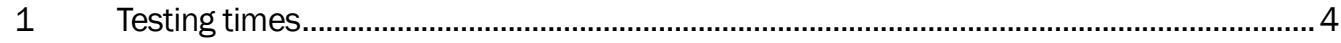

2 Summary of Montana BAEM test points from winter 2018................................................6

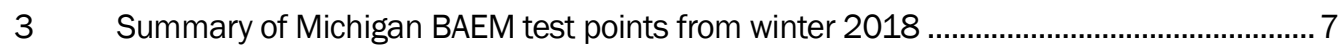

$4 \quad$ WV3 sensing bandwidths (DigitalGlobe 2012, 2014) ................................................32 
$5 \quad$ List of snow characterization parameters used in this study .......................................34

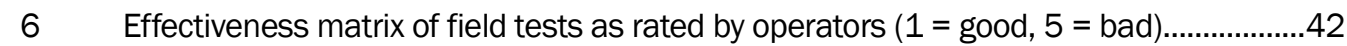

D-1 Montana snow data summary ………………….................................................... 105

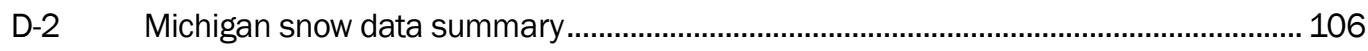

D-3 Montana Clegg data ........................................................................................... 108

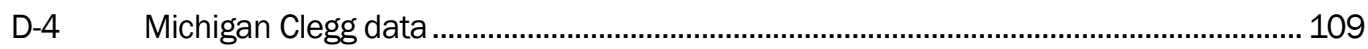

D-5 Montana Rammsonde data .................................................................................. 112

D-6 Michigan Rammsonde data .................................................................................. 113

D-7 Additional Michigan Rammsonde data ……………………………....................... 114

D-8 Montana Russian Snow Penetrometer data ................................................................... 115

D-9 Michigan Russian Snow Penetrometer data................................................................ 115

D-10 Additional Michigan Russian Snow Penetrometer data ............................................... 116

D-11 Further Michigan Russian Snow Penetrometer data .....................................................117

F-1 Spearman correlations between WorldView-2 multispectral bands and snow mechanical measurements (Michigan). The $p$-values are indicated

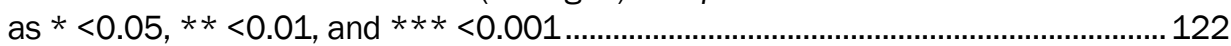




\section{Preface}

This study was conducted for the Assistant Secretary of the Army for Acquisition, Logistics, and Technology under project number 465395, "Boreal Aspects of Ensured Maneuver (BAEM)," which is part of the U.S. Army Engineer Research and Development Center (ERDC) 6.2 Remote Assessment of Infrastructure for Ensured Maneuver (RAFTER) Program managed by Ms. Danielle Whitlow, ERDC Geotechnical and Structures Laboratory (GSL). This work is continuing under project number 471941, "Remote Assessment of Snow Mechanical Properties" and "Mobility in Peat and Northern Soils," under the Entry and Sustainment in Complex Contested Environments Program managed by Dr. John Rushing, GSL.

The work was performed by Force Projection and Sustainment Branch (CEERD-RRH), the Terrestrial and Cryospheric Sciences Branch (CEERDRRG), and the Biogeochemical Sciences Branch (CEERD-RRN) of the Research and Engineering Division (CEERD-RR) and the Lidar and Wetlands Group of the Remote Sensing / Geographic Information Systems Center of Expertise (CEERD-RS), U.S. Army Engineer Research and Development Center, Cold Regions Research and Engineering Laboratory (ERDC-CRREL). At the time of publication, Mr. Justin Putnam was Acting Chief, CEERDRRH; Dr. John Weatherly was Chief, CEERD-RRG; Dr. Justin Berman was Chief, CEERD-RRN; Dr. Elias Deeb was lead for the Lidar and Wetlands Group; Mr. Jared Oren was Acting Chief, CEERD-RR; and Mr. David Finnegan was Chief, CEERD-RS. The Deputy Director of ERDC-CRREL was Mr. David B. Ringelberg, and the Director was Dr. Joseph L. Corriveau.

The authors acknowledge the following people for field support: Mr. Charlie Smith, Mr. Andrew Bernier, Mr. Jason Olivier, Mr. Mike Ekegren, Dr. Susan Frankenstein, and Dr. Carrie Vuyovich of CRREL; Mr. Tate Meehan of Boise State University; and Dr. Russ Alger of the Michigan Technical University. Dr. John Fegyveresi, CRREL, analyzed and plotted the snow pit data; and Ms. Michelle Michaels, CRREL, helped with analysis of the field spectrometer data. Ms. Kathleen Jones, CRREL, and Dr. H.P. Marshall, Boise State University, provided manuscript review comments. Assistance was also provided by the staff of the Nevada Automotive Test Center during testing at West Yellowstone, Montana, and the staff of the Keweenaw Research Center during testing in Calumet, Michigan.

COL Ivan P. Beckman was Commander of ERDC, and Dr. David W. Pittman was the Director. 


\section{Acronyms and Abbreviations}

ASD

AWS

BAEM

CAVIS

CBR

CIV

Clegg

CRREL

ERDC

FM

FWD

FY

GPR

GPS

GSL

ISM

KRC

LL

LWD

MS

NASA

NATC
Analytic Spectral Devices Field-Spec4 Hi-Res Spectroradiometer

Automated Weather Station

Boreal Aspects of Ensured Maneuver

Clouds, Aerosols, Vapors, Ice, and Snow

California Bearing Ratio

Clegg Impact Value

Clegg Impact Hammer

Cold Regions Research and Engineering Laboratory

U.S. Army Engineer Research and Development Center

Field Manual

Falling Weight Deflectometer

Fiscal Year

Ground-Penetrating Radar

Global Positioning System

Geotechnical and Structures Laboratory

Impulse Stiffness Modulus

Keweenaw Research Center

Load Level

Light Weight Deflectometer

Multispectral

National Air and Space Administration

Nevada Automotive Test Center 


$\begin{array}{ll}\text { NDVI } & \text { Normalized Difference Vegetation Index } \\ \text { NIR } & \text { Near-Infrared } \\ \text { RAFTER } & \text { Remote Assessment of Infrastructure for Ensured Maneuver } \\ \text { ram } & \text { Rammsonde } \\ \text { RSP } & \text { Russian Snow Penetrometer } \\ \text { SMP } & \text { SnowMicroPenetrometer } \\ \text { SWIR } & \text { Shortwave Infrared } \\ \text { TACOM } & \text { Tank Automotive Command } \\ \text { TSX } & \text { TerraSAR-X } \\ \text { USACE } & \text { U.S. Army Corps of Engineers } \\ \text { WV2 } & \text { WorldView-2 } \\ \text { WV3 } & \text { WorldView-3 }\end{array}$




\section{Unit Conversion Factors}

\begin{tabular}{|c|c|c|}
\hline Multiply & By & To Obtain \\
\hline acres & $4,046.873$ & square meters \\
\hline cubic feet & 0.02831685 & cubic meters \\
\hline cubic inches & 1.6387064 E-05 & cubic meters \\
\hline degrees (angle) & 0.01745329 & radians \\
\hline degrees Fahrenheit & $(\mathrm{F}-32) / 1.8$ & degrees Celsius \\
\hline feet & 0.3048 & meters \\
\hline inches & 0.0254 & meters \\
\hline kips & 4448.22 & newtons \\
\hline microinches & 0.0254 & micrometers \\
\hline miles (U.S. statute) & $1,609.347$ & meters \\
\hline mils & 0.0254 & millimeters \\
\hline pounds (force) & 4.448222 & newtons \\
\hline pounds (force) per square inch & 6.894757 & kilopascals \\
\hline pounds (mass) & 0.45359237 & kilograms \\
\hline pounds (mass) per cubic foot & 16.01846 & kilograms per cubic meter \\
\hline pounds (mass) per cubic inch & $2.757990 \mathrm{E}+04$ & kilograms per cubic meter \\
\hline square feet & 0.09290304 & square meters \\
\hline square inches & $6.4516 \mathrm{E}-04$ & square meters \\
\hline square miles & $2.589998 E+06$ & square meters \\
\hline
\end{tabular}





\section{Introduction}

\subsection{Background}

The U.S. military has been fighting in the desert for the last 20 years and is therefore ill-prepared to apply new technologies to cold regions environments consisting of freeze and thaw, heavily organic and vegetated terrain, and snow and ice cover. To address this issue, a one-year pilot study in Fiscal Year (FY) 2018, Boreal Aspects of Ensured Maneuver (BAEM), assessed terrain in boreal terrestrial lands, specifically those unique to the far north, such as snow, ice, freezing and thawing soils, and peat and organic soils. These investigations will inform future in-depth research into maneuver in Arctic and boreal terrestrial lands of concern in military conflict. These boreal terrains are typically saturated and weak during thaw and summer rainy seasons but can be strong when frozen. Additionally, characterization for trafficability during winter, when the snow cover is ubiquitous, is of prime importance to military ground operations.

Several efforts were part of the larger BAEM study. This report documents specifically efforts to characterize winter terrain with various mechanical testing methods and spectral imaging.

\subsection{Objectives}

The objectives of this portion of the larger BAEM project were twofold:

1. Determine methods to measure and classify the mechanical behavior of unique northern terrain important to entry and maneuver, specifically snow-covered terrain.

2. Assess the accuracy of current capabilities and evaluate enhancements to physics algorithms and satellite-based sensing techniques focusing on physical and mechanical properties of snow.

\subsection{Approach}

To accomplish these objectives, the U.S. Army Engineer Research and Development Center's Cold Regions Research and Engineering Laboratory (ERDC-CRREL) team collected data on snow and ice physical and optical characteristics with concurrent satellite data collections at two sites: the Nevada Automotive Test Center's (NATC) Winter Test Facility located at 
the West Yellowstone Airport, West Yellowstone, Montana, and the Keweenaw Research Center (KRC), Calumet, Michigan.

Both facilities run a wide range of winter vehicle testing over a multitude of surfaces with many types of vehicles, both military and commercial. Testing during our field experiments included a variety of measurements to characterize snow in the virgin snowpack and on numerous groomed or trafficked snow surfaces. The specific testing during the two field campaigns varied based on availability of equipment and personnel. Section 3 discusses this further.

We performed various mechanical tests to characterize the basic properties of the groomed and virgin snow surfaces. They included a range of strength tests, some more suited to one snow surface than the other. Several of the tests (i.e., California Bearing Ratio [CBR] and Clegg Impact Hammer [Clegg]) are commonly used for pavement materials and soils testing. Our study evaluated the effectiveness of these tools on snow surfaces, as well as tools specifically designed for use on snow, such as the Rammsonde (ram) and Russian Snow Penetrometer (RSP). Additional testing and measurements documented the snow depth, density, moisture content, and temperature to investigate possible correlations with snow strength.

Lastly ground-based measurements of spectral reflectance were made using an Analytical Spectral Devices (ASD) Field-Spec4 Hi-Res spectroradiometer (which we refer to as the ASD), and satellite acquisitions from WorldView-3 (WV3) multispectral optical imagery and TerraSAR-X (TSX) radar imagery that were obtained concurrently with the field campaigns.

This report documents the field methods and assesses the mechanical measurement techniques and the multispectral optical measurements based on the snow surface type. Further mechanical measurements took place in conjunction with vehicle testing and will be analyzed in a separate report. 


\section{Field Sites}

Both the NATC and KRC test sites were large facilities with several other functions and testing programs happening concurrently with our efforts. This sometimes resulted in undocumented vehicle traffic, especially on the snow road surfaces used for durability and handling testing unrelated to the BAEM study.

\subsection{Montana}

NATC maintains approximately 20 hectares (49 acres) of groomed test surfaces. Test surfaces are maintained at medium pack $\left(70-80 \mathrm{CTI}^{*}\right)$, soft pack (50-70 CTI), and hard pack (80-90 CTI), with virgin snow and ice surfaces also available. The vehicle test areas include, but are not limited to, the following:

- Airport terminal apron, groomed snow over asphalt pavement $(677 \mathrm{~m}$ $\times 76 \mathrm{~m}[2220 \mathrm{ft} \times 250 \mathrm{ft}])$

- Taxiway, groomed snow over asphalt pavement $(2560 \mathrm{~m} \times 23 \mathrm{~m}$ $[8400 \mathrm{ft} \times 75 \mathrm{ft}])$

- Runway, groomed snow over asphalt pavement $(2560 \mathrm{~m} \times 46 \mathrm{~m}$ [8400 ft $\times 150 \mathrm{ft}])$

- Vehicle mobility loop, through snowpack over unsurfaced terrain

- Virgin snow

We conducted the field experiments at West Yellowstone, Montana, from 24 January to 2 February 2018. They included vehicle mobility testing, onsite snow assessment, and concurrent satellite collections. CRREL collaborated with the U.S. Marine Corps, NATC, and Boise State University to perform these experiments.

On 24 January, a section of bare asphalt concrete pavement was still uncovered by snow at the south end of the taxiway. After this day, a new snowfall buried the bare pavement and provided three basic snow surfaces: snow over asphalt concrete runway, snow over asphalt concrete taxiway, and virgin snow over the grass fields adjacent to the airport's paved surfaces.

* CTI is a measure of snow-surface compaction discussed further in section 3.1.5 
Testing in Montana occurred during various hours (the hours are significant because some of the electronic test equipment changed dates during night shifts). The times in Table 1 are local time.

Table 1. Testing times.

\begin{tabular}{|c|c|}
\hline Day & Time \\
\hline 25 Jan. 2018 & 19:00-4:30 (the next day) \\
\hline 26 Jan. 2018 & 19:00-1:30 \\
\hline 27 Jan. 2018 & 15:00-22:30 \\
\hline 28 Jan. 2018 & 12:30-20:00 \\
\hline 29 Jan. 2018 & $8: 00-17: 00$ \\
\hline 30 Jan. 2018 & $5: 30-15: 00$ \\
\hline 31 Jan. 2018 & 4:30-12:30 \\
\hline
\end{tabular}

These work hours were chosen to reduce thermal changes in the snow surfaces and to accommodate other testing at the site.

\subsection{Michigan}

The second field campaign was completed at KRC in Calumet, Michigan, from 19 to 23 February 2018. KRC is a research agency of Michigan Technological University. Its goal is to generate and conduct externally funded research that supports the university's overall education mission.

The site is located in the Upper Peninsula of Michigan adjacent to the Houghton Memorial Airport, $11 \mathrm{~km}$ (7 miles) north of the main Michigan Tech campus. KRC is the former test site of the U.S. Army Tank Automotive Command (TACOM), and TACOM continues to sponsor research and testing at KRC.

The test course consists of over 365 hectares (900 acres) of test areas, such as handling loops, a circular track, and slopes. The variety of terrain, combined with northern Michigan's wide-ranging weather conditions, allows for realistic field evaluations. The course is used year-round for acceleration and braking, slope climbing, noise, vibration, obstacle crossing, and endurance tests. Every winter, special ice and snow areas are constructed for ride and handling studies, antilock brake tests, and tire traction evaluations.

The KRC Winter Test Facility includes several prepared snow and ice surfaces: 
- Three vehicle handling loops

- Several packed-snow vehicle dynamics pads

- Packed-snow slopes of 7, 10, 15, 20, 25, and 30 percent grade

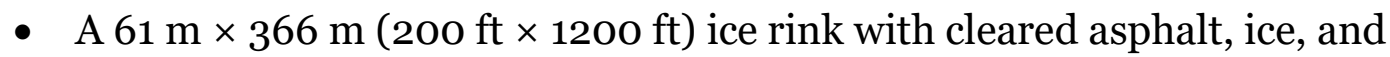
snow lanes

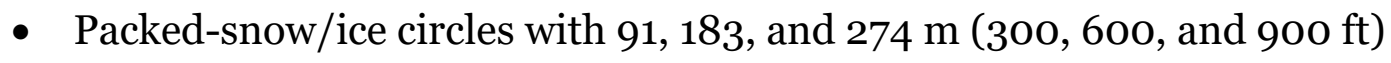
inside diameters

- Naturally vegetated terrain with virgin snow cover adjacent to the prepared surfaces

Testing in Michigan was during standard daylight work hours.

\subsection{Test-point discussion}

The BAEM test points, such as 19RWYo, are labeled as follows. The first two numbers indicate the testing date, such as 19 January. The next three or four letters indicate the surface type or location, such as runway. The final numbers or letters are a descriptor of the point on the surface. During the actual testing, different names may have been given to test points. The naming was normalized during the data transcription and preanalysis processing to ensure the correct data were attributed to the correct test point.

Tables 2 and 3 list the test points with the date of testing; approximate local time; and a description of the test point, ground surface, and snow-surface conditions at the time of each test. The time spent at a specific location depended on the number of points in the vicinity, the number of tests applicable to that area's snow conditions, and the number of team members working in the area. Some points, such as 27RWYSVS and 27TWYSVS, had additional testing in the same vicinity later in the test program. Figures $1-5$ show the test points used in this study. Appendix A provides additional views of the test areas, and Appendix B provides photos of the various ground surfaces in Michigan without snow cover.

In Montana, again, some testing days stared at 22:00 and went into the morning of the next day. For these points, the two-digit date designator was the date that testing started. Therefore, some points with designator " 25 " actually may have been tested during the early morning hours of 26 January. 
Table 2. Summary of Montana BAEM test points from winter 2018.

\begin{tabular}{|c|c|c|c|c|c|c|c|}
\hline Test Point & Date & $\begin{array}{l}\text { Approximate } \\
\text { local time }\end{array}$ & $\begin{array}{l}\text { Longitude } \\
\text { (Degrees) }\end{array}$ & $\begin{array}{l}\text { Latitude } \\
\text { (Degrees } \\
\text { North) }\end{array}$ & Description & Snow Surface & Ground Surface \\
\hline 25RWYO & $1 / 25 / 2018$ & 21:45-23:00 & -111.115 & 44.693 & Runway, north end-point 0 & Fresh over groomed snow & Asphalt concrete pavement \\
\hline 25RWY50 & $1 / 25 / 2018$ & 22:00-23:00 & -111.115 & 44.693 & Runway, north end-point 50 & Fresh over groomed snow & Asphalt concrete pavement \\
\hline 25RWY100 & $1 / 25 / 2018$ & 22:00-23:00 & -111.115 & 44.692 & Runway, north end-point 100 & Fresh over groomed snow & Asphalt concrete pavement \\
\hline 25TWYO & $1 / 26 / 2018$ & $2: 45-3: 45$ & -111.114 & 44.691 & Taxiway, north end-point 0 & Fresh over groomed snow & Asphalt concrete pavement \\
\hline 25TWY50 & $1 / 26 / 2018$ & $2: 45-3: 45$ & -111.114 & 44.691 & Taxiway, north end-point 50 & Fresh over groomed snow & Asphalt concrete pavement \\
\hline 25TWY100 & $1 / 26 / 2018$ & $2: 45-3: 45$ & -111.114 & 44.691 & Taxiway, north end-point 100 & Fresh over groomed snow & Asphalt concrete pavement \\
\hline 27RWYSVS & $1 / 27 / 2018$ & $17: 50-18: 50$ & -111.125 & 44.679 & $\begin{array}{l}\text { Off south end of runway to the west, } \\
\text { also tested on other days as } \\
\text { 29RWYSVS, 3ORWYSVS, and } \\
\text { 31RSWVS }\end{array}$ & Virgin snow & $\begin{array}{l}\text { Minimally maintained, leveled } \\
\text { terrain over sandy soil }\end{array}$ \\
\hline 27TWYSVS & $1 / 27 / 2018$ & $19: 00-20: 00$ & -111.123 & 44.677 & $\begin{array}{l}\text { Off south end of taxiway, also tested } \\
\text { as 29TWYSVS }\end{array}$ & Virgin snow & $\begin{array}{l}\text { Minimally maintained, leveled } \\
\text { terrain over sandy soil }\end{array}$ \\
\hline 28MLPW & $1 / 28 / 2018$ & $15: 20-17: 00$ & -111.117 & 44.692 & Mobility Loop, west straightaway & Rutted snowpack & $\begin{array}{l}\text { Minimally maintained, leveled } \\
\text { terrain over sandy soil }\end{array}$ \\
\hline 29RWYC & $1 / 29 / 2018$ & $10: 45-11: 30$ & -111.116 & 44.691 & Runway, center & Groomed snow & $\begin{array}{l}\text { Minimally maintained, leveled } \\
\text { terrain over sandy soil }\end{array}$ \\
\hline 30MLPN & $1 / 30 / 2018$ & 7:00-11:00 & -111.109 & 44.699 & $\begin{array}{l}\text { Mobility Loop, entrance at north end of } \\
\text { the taxiway }\end{array}$ & Rutted snowpack & $\begin{array}{l}\text { Minimally maintained, leveled } \\
\text { terrain over sandy soil }\end{array}$ \\
\hline 31RWYC & $1 / 31 / 2018$ & $5: 45-6: 30$ & -111.116 & 44.691 & Runway, center & Groomed snow & $\begin{array}{l}\text { Minimally maintained, leveled } \\
\text { terrain over sandy soil }\end{array}$ \\
\hline
\end{tabular}


Table 3. Summary of Michigan BAEM test points from winter 2018.

\begin{tabular}{|c|c|c|c|c|c|c|c|}
\hline Test Point & Date & $\begin{array}{l}\text { Approximate } \\
\text { Local Time }\end{array}$ & $\begin{array}{l}\text { Longitude } \\
\text { (Degrees) }\end{array}$ & $\begin{array}{c}\text { Latitude } \\
\text { (Degrees } \\
\text { North) }\end{array}$ & Description & Snow Surface & Ground Surface \\
\hline 19SU2_A & $2 / 19 / 2018$ & 10:00-15:30 & -88.509 & 47.164 & Spin Up Pad 2-point A & Fresh over groomed snow & Grass over brown silty sand with grave \\
\hline 19SU2_B & $2 / 19 / 2018$ & 10:00-15:30 & -88.509 & 47.164 & Spin Up Pad 2-point B & Fresh over groomed snow & Grass over brown silty sand with grave \\
\hline 19SU2_C & $2 / 19 / 2018$ & 10:00-15:30 & -88.509 & 47.164 & Spin Up Pad 2-point C & Fresh over groomed snow & Grass over brown silty sand with grave \\
\hline 19SU2_D & $2 / 19 / 2018$ & 10:00-15:30 & -88.509 & 47.164 & Spin Up Pad 2-point D & Fresh over groomed snow & Grass over brown silty sand with grave \\
\hline 19SU2_E & $2 / 19 / 2018$ & 10:00-15:30 & -88.509 & 47.163 & Spin Up Pad 2-point E & Fresh over groomed snow & Grass over brown silty sand with grave \\
\hline 19SU2_F & $2 / 19 / 2018$ & 10:00-15:30 & -88.509 & 47.164 & Spin Up Pad 2-point F & Fresh over groomed snow & Grass over brown silty sand with grave \\
\hline 19SU2VS_A & $2 / 19 / 2018$ & $14: 30-16: 00$ & -88.510 & 47.164 & $\begin{array}{l}\text { Spin Up Pad 2, old road virgin snow- } \\
\text { point A }\end{array}$ & Virgin snow & $\begin{array}{l}\text { Natural terrain-glacial loamy silts and } \\
\text { sands }\end{array}$ \\
\hline 19SU2VS_B & $2 / 19 / 2018$ & 14:30-16:00 & -88.510 & 47.164 & $\begin{array}{l}\text { Spin Up Pad 2, old road virgin snow- } \\
\text { point B }\end{array}$ & Virgin snow & $\begin{array}{l}\text { Natural terrain-glacial loamy silts and } \\
\text { sands }\end{array}$ \\
\hline 19SU2VS_C & $2 / 19 / 2018$ & 14:30-16:00 & -88.510 & 47.164 & $\begin{array}{l}\text { Spin Up Pad 2, old road virgin snow- } \\
\text { point C }\end{array}$ & Virgin snow & $\begin{array}{l}\text { Natural terrain-glacial loamy silts and } \\
\text { sands }\end{array}$ \\
\hline 19SU2VS_D & $2 / 19 / 2018$ & 14:30-16:00 & -88.510 & 47.164 & $\begin{array}{l}\text { Spin Up Pad 2, old road virgin snow- } \\
\text { point D }\end{array}$ & Virgin snow & $\begin{array}{l}\text { Natural terrain-glacial loamy silts and } \\
\text { sands }\end{array}$ \\
\hline 19SU2VS_E & $2 / 19 / 2018$ & 14:30-16:00 & -88.510 & 47.164 & $\begin{array}{l}\text { Spin Up Pad 2, old road virgin snow- } \\
\text { point E }\end{array}$ & Virgin snow & $\begin{array}{l}\text { Natural terrain-glacial loamy silts and } \\
\text { sands }\end{array}$ \\
\hline 20LP1WG_1 & $2 / 20 / 2018$ & 10:00-11:30 & -88.505 & 47.160 & $\begin{array}{l}\text { Loop 1, washed gravel subgrade- } \\
\text { point } 1\end{array}$ & $\begin{array}{l}\text { Freezing rain and fresh } \\
\text { snow over groomed snow }\end{array}$ & Compacted road gravel \\
\hline 20LP1WG_2 & $2 / 20 / 2018$ & 10:00-11:30 & -88.506 & 47.160 & $\begin{array}{l}\text { Loop 1, washed gravel subgrade- } \\
\text { point } 2\end{array}$ & $\begin{array}{l}\text { Freezing rain and fresh } \\
\text { snow over groomed snow }\end{array}$ & Compacted road gravel \\
\hline 20LP1WG_3 & $2 / 20 / 2018$ & 10:00-11:30 & -88.506 & 47.160 & $\begin{array}{l}\text { Loop 1, washed gravel subgrade- } \\
\text { point } 3\end{array}$ & $\begin{array}{l}\text { Freezing rain fresh snow } \\
\text { over groomed snow }\end{array}$ & Compacted road gravel \\
\hline 20LP1GS_4 & $2 / 20 / 2018$ & $12: 30-15: 00$ & -88.505 & 47.159 & Loop 1, grass subgrade-point 4 & $\begin{array}{l}\text { Freezing rain fresh snow } \\
\text { over groomed snow }\end{array}$ & Grass over brown silty sand with grave \\
\hline 20LP1GS_5 & $2 / 20 / 2018$ & $12: 30-15: 00$ & -88.505 & 47.159 & Loop 1, grass subgrade-point 5 & $\begin{array}{l}\text { Freezing rain fresh snow } \\
\text { over groomed snow }\end{array}$ & Grass over brown silty sand with grave \\
\hline 20LP1GS_6 & $2 / 20 / 2018$ & $12: 30-15: 00$ & -88.505 & 47.159 & Loop 1, grass subgrade-point 6 & $\begin{array}{l}\text { Freezing rain fresh snow } \\
\text { over groomed snow }\end{array}$ & Grass over brown silty sand with grave \\
\hline 20GPVS & $2 / 20 / 2018$ & 15:10-15:45 & -88.508 & 47.157 & Gravel pad virgin snow next to Loop 1 & Virgin snow & Compacted road gravel \\
\hline 21SWP_1 & $2 / 21 / 2018$ & $8: 00-9: 30$ & -88.494 & 47.159 & Sweeper parking pad-point 1 & Fresh over groomed snow & Grass over brown silty sand with grave \\
\hline 21SWP_2 & $2 / 21 / 2018$ & $8: 00-9: 30$ & -88.495 & 47.159 & Sweeper parking pad-point 2 & Fresh over groomed snow & Grass over brown silty sand with grave \\
\hline
\end{tabular}


Table 3 (cont.). Summary of Michigan BAEM test points from winter 2018.

\begin{tabular}{|c|c|c|c|c|c|c|c|}
\hline Test Point & Date & $\begin{array}{l}\text { Approximate } \\
\text { Local Time }\end{array}$ & $\begin{array}{l}\text { Longitude } \\
\text { (Degrees) }\end{array}$ & $\begin{array}{c}\text { Latitude } \\
\text { (Degrees } \\
\text { North) }\end{array}$ & Description & Snow Surface & Ground Surface \\
\hline 21SWP_3 & $2 / 21 / 2018$ & $8: 00-9: 30$ & -88.495 & 47.159 & Sweeper parking pad-point 3 & Fresh over groomed snow & Grass over brown silty sand with gravel \\
\hline 21IS_S & $2 / 21 / 2018$ & 9:40-11:00 & -88.495 & 47.159 & Ice slopes next to sweeper pad, steep & Virgin snow over ice & Compacted road gravel \\
\hline 21IS_L & $2 / 21 / 2018$ & 9:40-11:00 & -88.495 & 47.159 & Ice slopes next to sweeper pad, lower & Virgin snow over ice & Grass over brown silty sand with gravel \\
\hline 21SU1_1 & $2 / 21 / 2018$ & 13:00-13:45 & -88.502 & 47.166 & Spin Up Pad 1-point 1 & Groomed snow & Compacted road gravel \\
\hline 21SU1_2 & $2 / 21 / 2018$ & 13:00-13:45 & -88.502 & 47.166 & Spin Up Pad 1-point 2 & Groomed snow & Compacted road gravel \\
\hline 21GPRD_1 & $2 / 21 / 2018$ & $14: 00-14 ; 45$ & -88.508 & 47.158 & $\begin{array}{l}\text { Loop } 1 \text { road adjacent to 21GPVS- } \\
\text { point } 1\end{array}$ & Groomed snow & Compacted road gravel \\
\hline 21GPRD_2 & $2 / 21 / 2018$ & $14: 00-14 ; 45$ & -88.508 & 47.158 & $\begin{array}{l}\text { Loop } 1 \text { road adjacent to 21GPVS- } \\
\text { point } 2\end{array}$ & Groomed snow & Compacted road gravel \\
\hline 21GPVS & $2 / 21 / 2018$ & $14: 00-14 ; 45$ & -88.508 & 47.157 & Gravel pad virgin snow next to Loop 1 & Virgin snow & Compacted road gravel \\
\hline 21SU2_A2 & $2 / 21 / 2018$ & $15: 00-16: 00$ & -88.508 & 47.163 & $\begin{array}{l}\text { Spin Up Pad 2-point A2 (further west } \\
\text { of original 2/19 point A) }\end{array}$ & Groomed snow & Grass over brown silty sand with gravel \\
\hline 21SU2_B2 & $2 / 21 / 2018$ & 15:00-16:00 & -88.507 & 47.163 & $\begin{array}{l}\text { Spin Up Pad 2-point B2 (different } \\
\text { from original 2/19 point B) }\end{array}$ & Groomed snow & Grass over brown silty sand with gravel \\
\hline 22SU3_1 & $2 / 22 / 2018$ & 8:00-9:00 & -88.507 & 47.160 & Spin Up Pad 3-point 1 & Groomed snow & Compacted road gravel \\
\hline 22SU3_2 & $2 / 22 / 2018$ & 8:00-9:00 & -88.507 & 47.160 & Spin Up Pad 3-point 2 & Groomed snow & Compacted road gravel \\
\hline 22SU3_3 & $2 / 22 / 2018$ & $8: 00-9: 40$ & -88.506 & 47.160 & Spin Up Pad 3-point 3 & Groomed snow & Compacted road gravel \\
\hline 22SU3VS & $2 / 22 / 2018$ & 9:40-11:00 & -88.507 & 47.160 & Spin Up Pad 3, virgin snow to north & Virgin snow & Grass over brown silty sand with gravel \\
\hline 22SU3VS_1 & $2 / 22 / 2018$ & 9:40-11:00 & -88.507 & 47.160 & Spin Up Pad 3, virgin snow to north & Virgin snow & Grass over brown silty sand with gravel \\
\hline 22SU3VS_3 & $2 / 22 / 2018$ & 9:40-11:00 & -88.507 & 47.160 & Spin Up Pad 3, virgin snow to north & Virgin snow & Grass over brown silty sand with gravel \\
\hline 22SU3VS_4 & $2 / 22 / 2018$ & 9:40-11:00 & -88.507 & 47.160 & Spin Up Pad 3, virgin snow to north & Virgin snow & Grass over brown silty sand with gravel \\
\hline 22SU3VS_5 & $2 / 22 / 2018$ & 9:40-11:00 & -88.507 & 47.160 & Spin Up Pad 3, virgin snow to north & Virgin snow & Grass over brown silty sand with gravel \\
\hline 22SU3VS_6 & $2 / 22 / 2018$ & 9:40-11:00 & -88.507 & 47.160 & Spin Up Pad 3, virgin snow to north & Virgin snow & Grass over brown silty sand with gravel \\
\hline 22SU2 & $2 / 22 / 2018$ & $11: 30-11: 45$ & -88.507 & 47.163 & $\begin{array}{l}\text { Spin Up Pad 2, near 21SU2_B2 } \\
\text { (furthest west) }\end{array}$ & Groomed snow & Grass over brown silty sand with gravel \\
\hline 22SU3 & $2 / 22 / 2018$ & $11: 50-12: 05$ & -88.505 & 47.160 & $\begin{array}{l}\text { Spin Up Pad } 3 \text { at the top of the sloped } \\
\text { roads }\end{array}$ & Groomed snow & Compacted road gravel \\
\hline 22SU3_7D & $2 / 22 / 2018$ & 11:50-12:05 & -88.505 & 47.160 & $\begin{array}{l}\text { Spin Up Pad 3, sloped access roads, } 7 \\
\text { degree }\end{array}$ & Groomed snow & Compacted road gravel \\
\hline 22SU3_10D & $2 / 22 / 2018$ & 11:50-12:05 & -88.505 & 47.160 & $\begin{array}{l}\text { Spin Up Pad 3, sloped access roads, } \\
10 \text { degree }\end{array}$ & Groomed snow & Compacted road gravel \\
\hline
\end{tabular}


Table 3 (cont.). Summary of Michigan BAEM test points from winter 2018.

\begin{tabular}{|c|c|c|c|c|c|c|c|}
\hline Test Point & Date & $\begin{array}{l}\text { Approximate } \\
\text { Local Time }\end{array}$ & $\begin{array}{l}\text { Longitude } \\
\text { (Degrees) }\end{array}$ & $\begin{array}{c}\text { Latitude } \\
\text { (Degrees } \\
\text { North) }\end{array}$ & Description & Snow Surface & Ground Surface \\
\hline 22SU3_15D & $2 / 22 / 2018$ & $11: 50-12: 05$ & -88.505 & 47.160 & $\begin{array}{l}\text { Spin Up Pad 3, sloped access roads, } \\
15 \text { degree }\end{array}$ & Groomed snow & Compacted road gravel \\
\hline 22SU3_2OD & $2 / 22 / 2018$ & 11:50-12:05 & -88.505 & 47.160 & $\begin{array}{l}\text { Spin Up Pad 3, sloped access roads, } \\
20 \text { degree }\end{array}$ & Groomed snow & Compacted road gravel \\
\hline 22LP3E & $2 / 22 / 2018$ & $12: 10^{*}$ & -88.484 & 47.162 & Loop 3 east & Groomed snow & Compacted road gravel \\
\hline 22LP3EVS & $2 / 22 / 2018$ & $12: 10^{*}$ & -88.484 & 47.162 & Loop 3 east, adjacent virgin snow & Virgin snow & Compacted road gravel \\
\hline 22IR_I & $2 / 22 / 2018$ & $12: 25^{*}$ & -88.496 & 47.159 & Ice rink, ice surface & Ice & Grass over brown silty sand with gravel \\
\hline 22IR_S & $2 / 22 / 2018$ & $12: 25^{*}$ & -88.496 & 47.159 & Ice rink, snow surface & Groomed snow & Grass over brown silty sand with gravel \\
\hline 22IR_AC & $2 / 22 / 2018$ & $12: 25^{*}$ & -88.496 & 47.159 & Ice rink, asphalt concrete surface & Asphalt & Asphalt concrete pavement \\
\hline 22STAB_S & $2 / 22 / 2018$ & $12: 35^{*}$ & -88.488 & 47.158 & Stability Test Area, snow & Groomed snow & Grass over well-graded sand/silt sand \\
\hline 22STAB_GI & $2 / 22 / 2018$ & $12: 40^{*}$ & -88.487 & 47.158 & Stability Test Area, grooved ice & Grooved ice & Grass over well-graded sand/silt sand \\
\hline 22VDA2_1 & $2 / 22 / 2018$ & $12: 50^{*}$ & -88.501 & 47.160 & Vehicle Dynamics Area 2 & Groomed snow & Grass over brown silty sand with gravel \\
\hline 22VDA2_2 & $2 / 22 / 2018$ & $12: 50^{*}$ & -88.501 & 47.159 & Vehicle Dynamics Area 2 & Groomed snow & Grass over brown silty sand with gravel \\
\hline $22900 \mathrm{C}$ & $2 / 22 / 2018$ & $12: 55^{\star}$ & -88.504 & 47.160 & $900 \mathrm{ft}$ circle & Groomed snow & Compacted road gravel \\
\hline $22300 \mathrm{C}$ & $2 / 22 / 2018$ & $13: 00^{*}$ & -88.503 & 47.159 & $300 \mathrm{ft}$ circle & Groomed snow & Compacted road gravel \\
\hline 22300CVS & $2 / 22 / 2018$ & $13: 10^{*}$ & -88.503 & 47.159 & $300 \mathrm{ft}$ circle, center virgin snow & Virgin snow & Grass over brown silty sand with gravel \\
\hline 22LP4 & $2 / 22 / 2018$ & $14: 30^{*}$ & -88.489 & 47.156 & Loop 4 & Groomed snow & Well-graded sand/silt sand \\
\hline 22LP4VS & $2 / 22 / 2018$ & $14: 30^{*}$ & -88.489 & 47.156 & Loop 4, adjacent virgin snow & Virgin snow & Grass over well-graded sand/silt sand \\
\hline 22LP3NW & $2 / 22 / 2018$ & $14: 50^{*}$ & -88.492 & 47.163 & Loop 3 northwest & Groomed snow & Compacted road gravel \\
\hline 22LP3NWVS & $2 / 22 / 2018$ & $14: 50^{*}$ & -88.492 & 47.163 & $\begin{array}{l}\text { Loop } 3 \text { northwest, adjacent virgin } \\
\text { snow }\end{array}$ & Virgin snow & $\begin{array}{l}\text { Natural terrain-glacial loamy silts and } \\
\text { sands }\end{array}$ \\
\hline 22STAB_GI2 & $2 / 22 / 2018$ & $15: 00^{*}$ & -88.487 & 47.158 & $\begin{array}{l}\text { Stability Test Area, grooved ice, } \\
\text { additional LWD with outer geophones }\end{array}$ & Groomed snow & Grass over well-graded sand/silt sand \\
\hline $23 \mathrm{HQP}$ & $2 / 23 / 2018$ & 10:00-10:45 & -88.504 & 47.170 & Headquarters parking lot & New snow & Grass over brown silty sand with gravel \\
\hline
\end{tabular}

* These points were tested in less than 10 minutes per site if possible. 
Figure 1. Montana test site at West Yellowstone Airport.

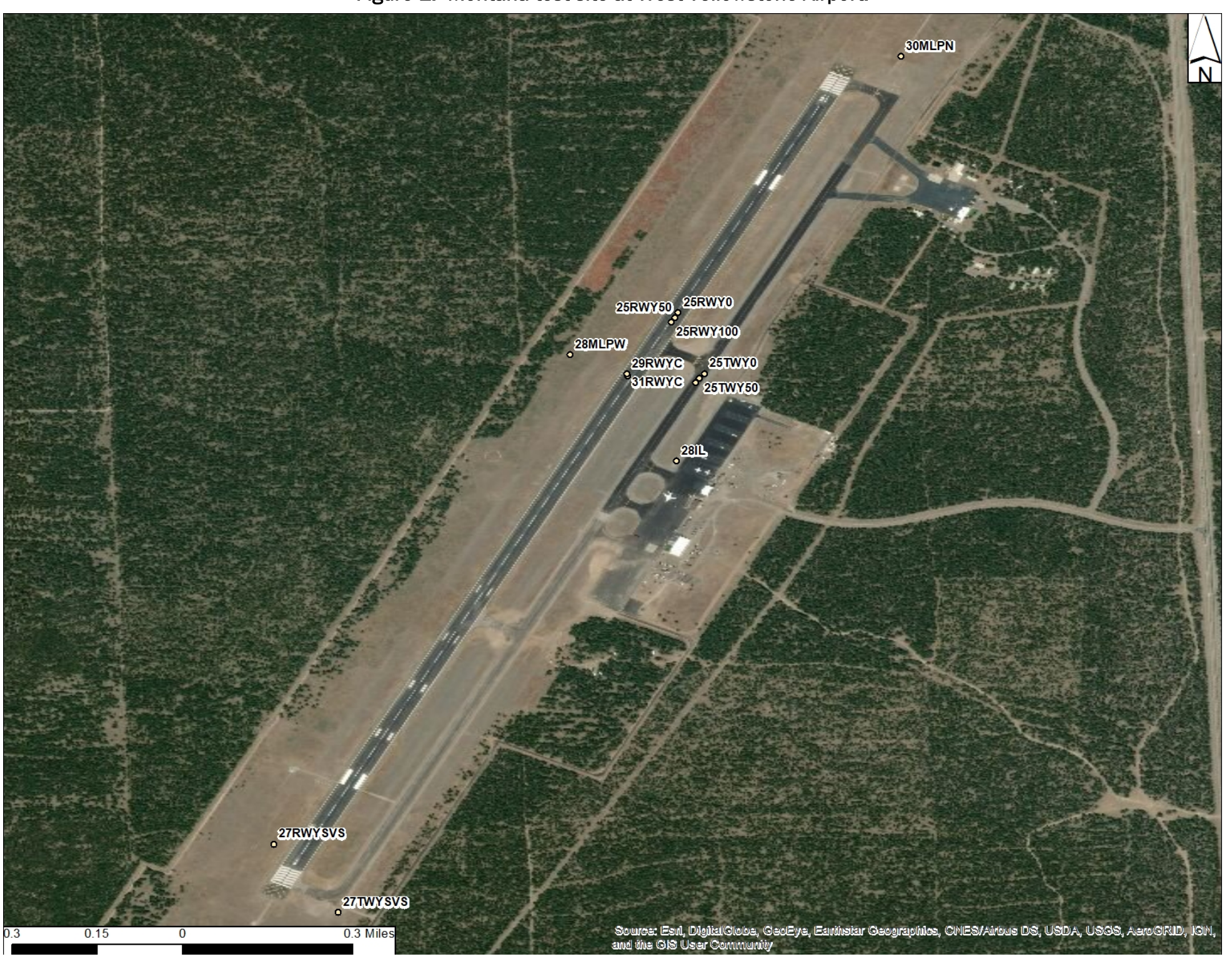


Figure 2. Montana test points superimposed over winter imagery taken during the field campaign.

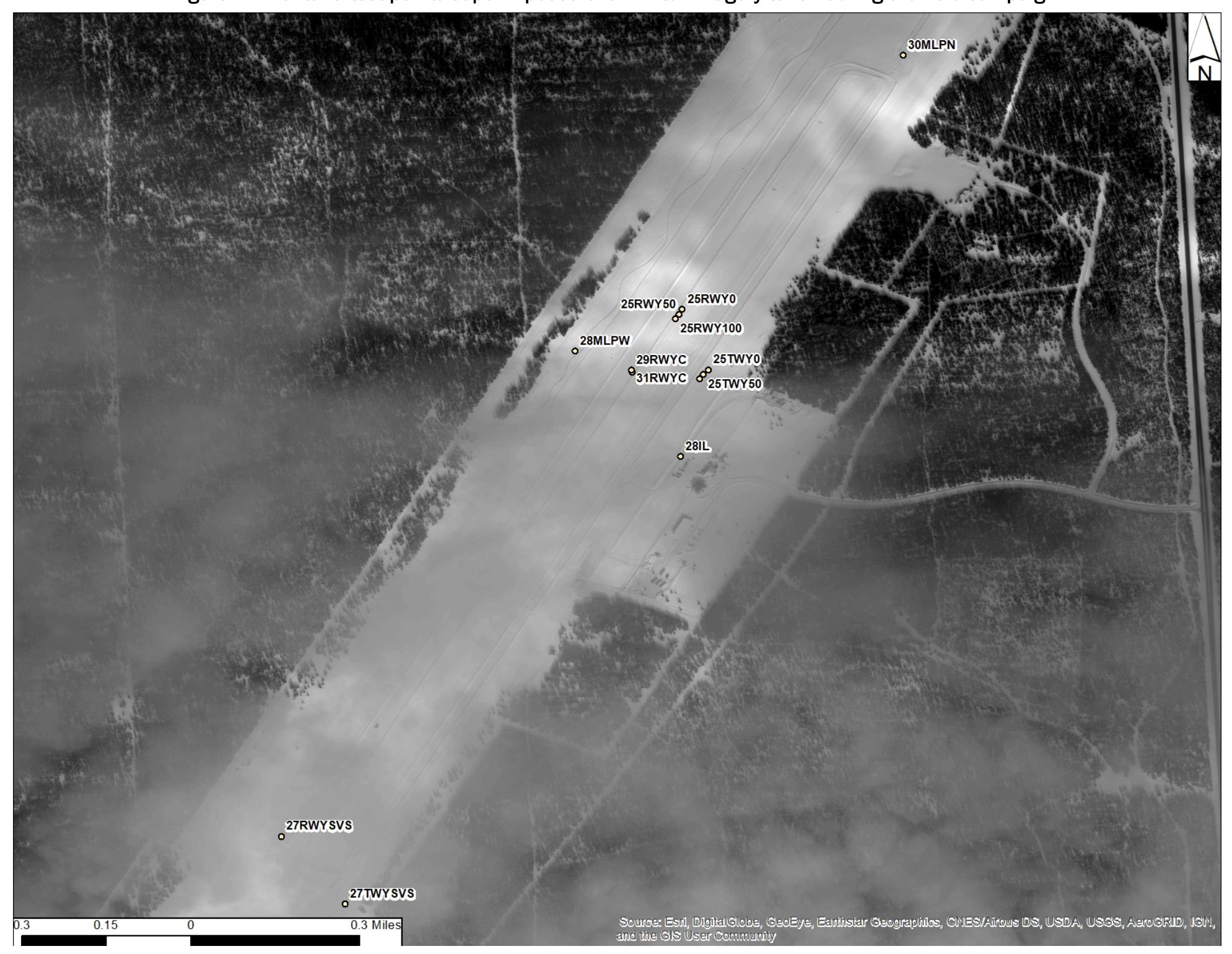


Figure 3. Schematic of the Michigan test site.

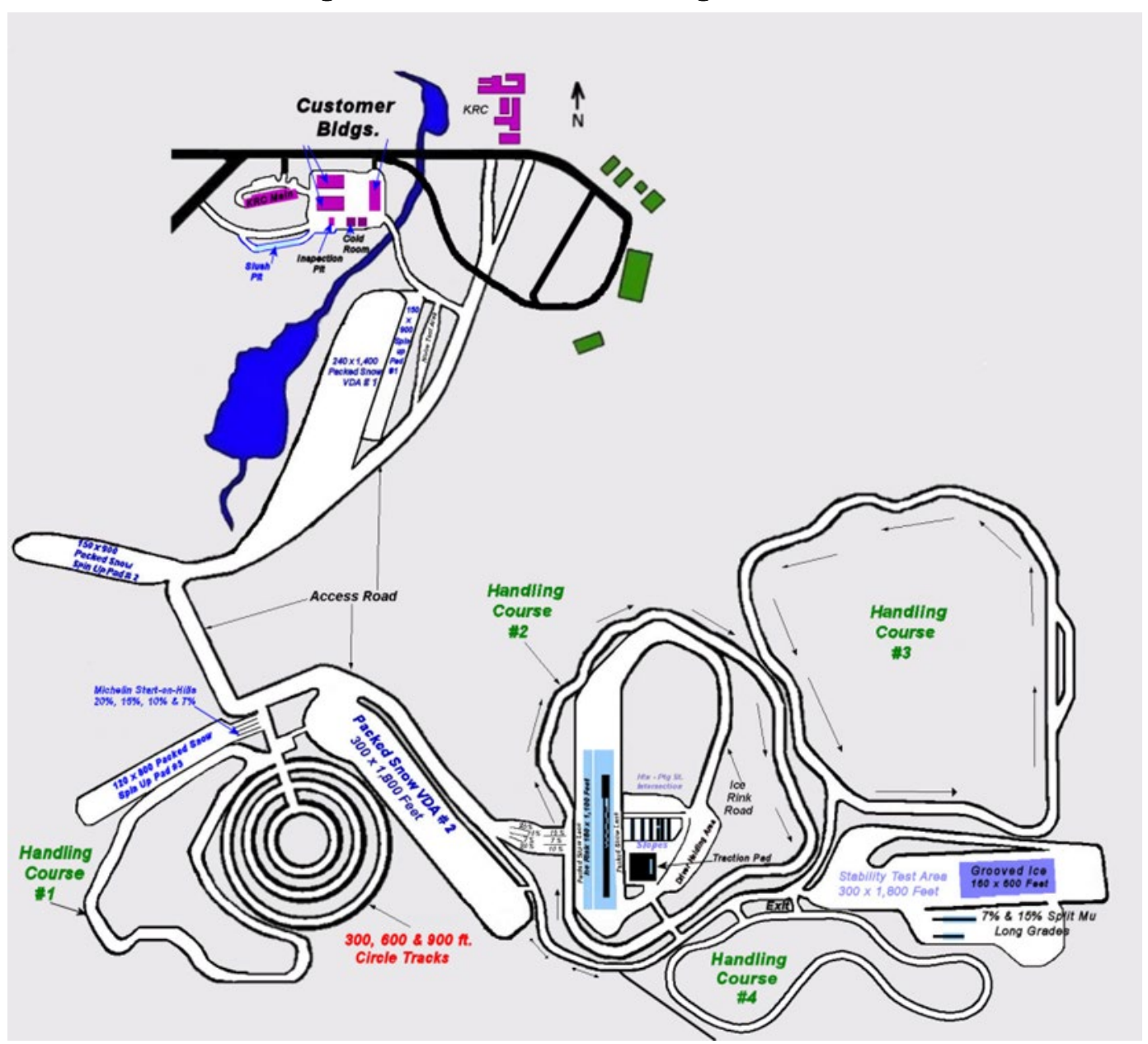


Figure 4. Michigan test points superimposed on imagery from summer to show to show ground surfaces.

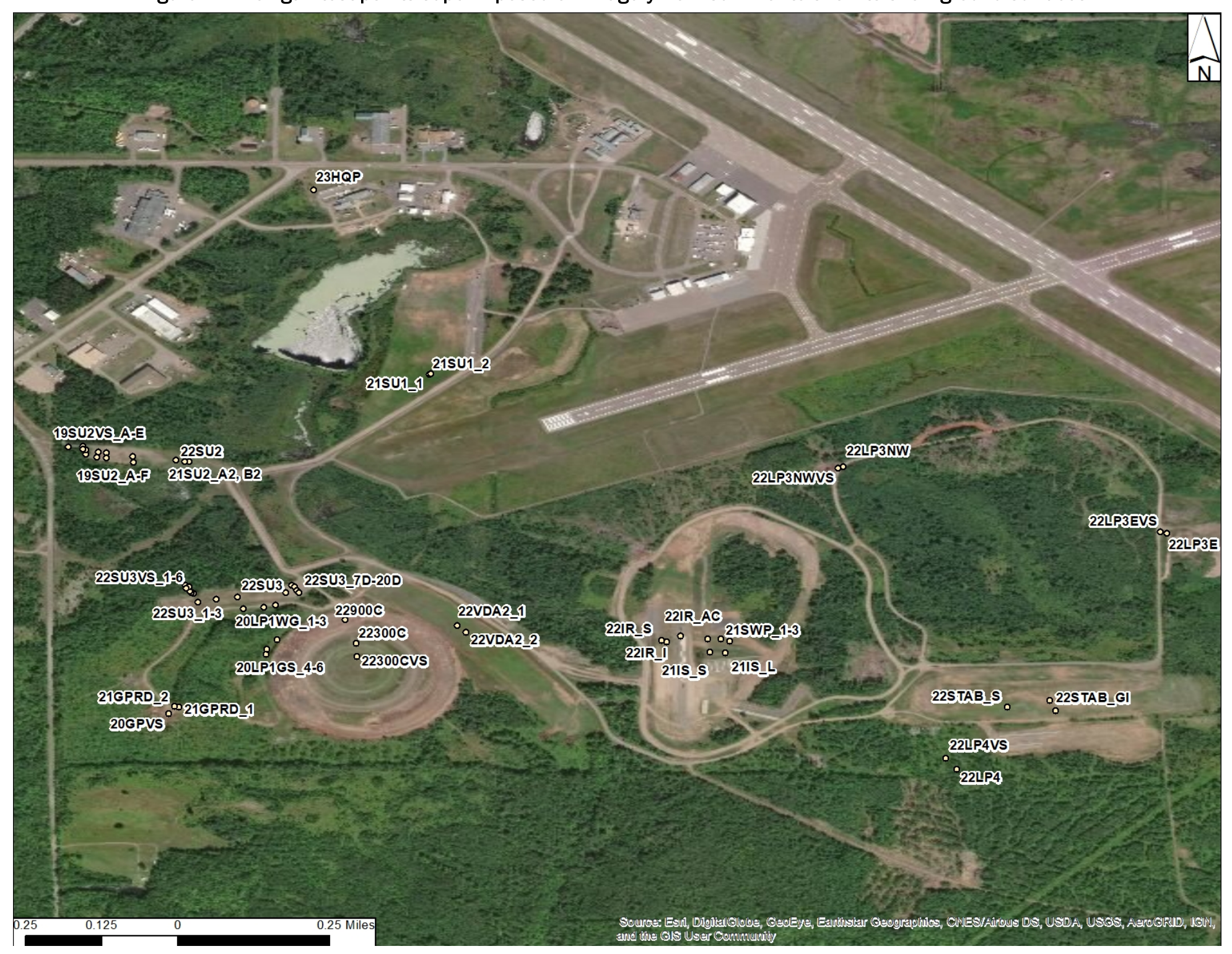


Figure 5. Michigan test points superimposed on winter imagery.

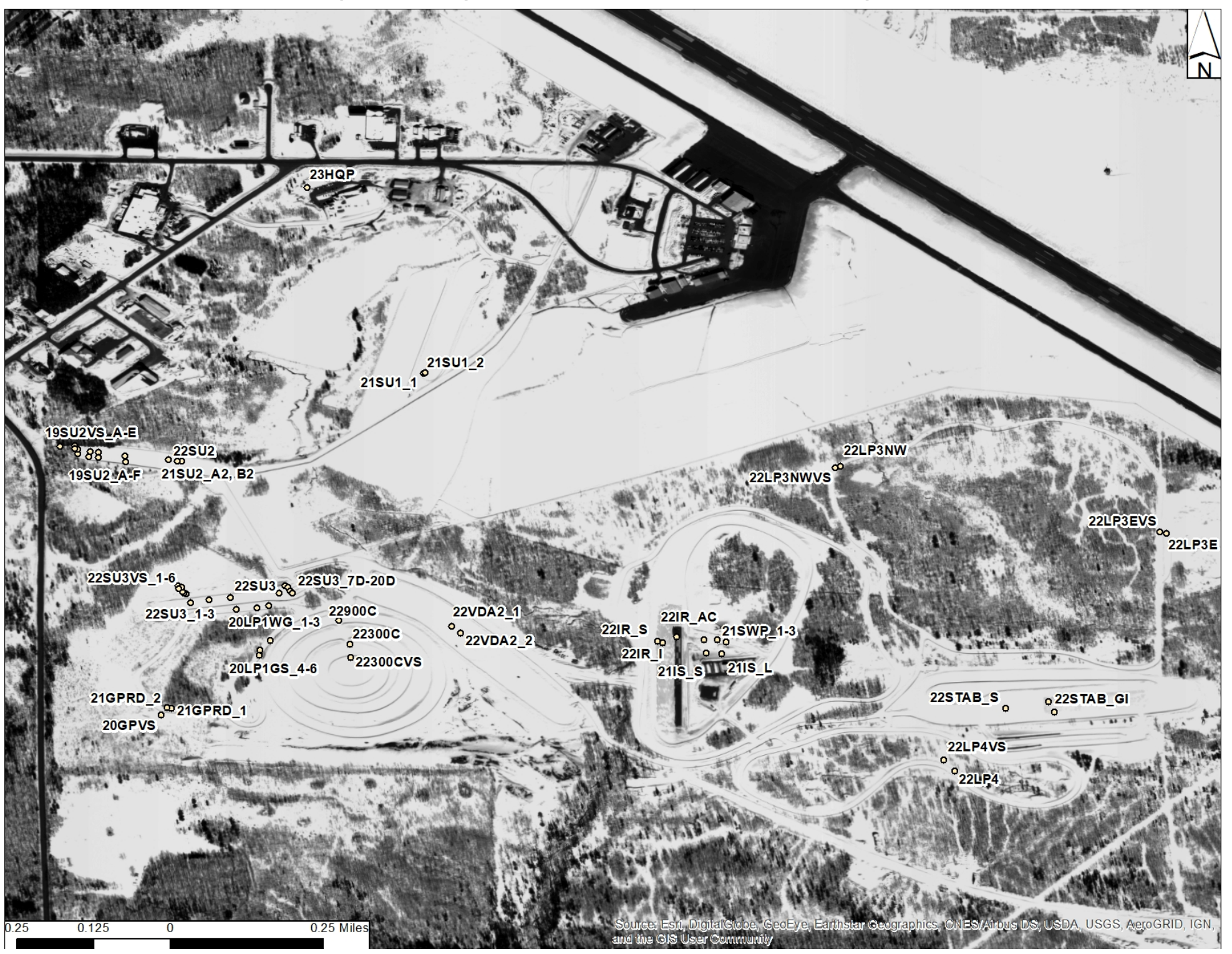




\section{Data Collection}

The capabilities, or measurement range, of each particular piece of testing equipment tended to fall in one of two categories: (1) soft snow and (2) hard or groomed snow. Soft snow was accumulated virgin snow, undisturbed by vehicles or any other activity except natural weather activity (i.e., wind, sun, and precipitation). Groomed snow had been prepared by plows, drags, or other grooming equipment or by vehicle traffic. The basic physical and optical properties measurements, however, were applicable both to groomed and soft snow surfaces: air and snow temperatures, snow density, reflectance, and $\mathrm{WV}_{3}$ and TSX satellite imagery.

The following lists summarize the test methods evaluated in this study, and the following sections fully describe each specific method. Not all equipment was used at every sampling location.

Mechanical measurements for groomed snow:

- Field CBR (Montana and Michigan)

- 0.5 and $2.25 \mathrm{~kg}$ (1.1 and $5 \mathrm{lb}$ ) Clegg (Montana and Michigan)

- Light Weight Deflectometer (LWD) (Montana and Michigan)

- RSP (Montana and Michigan)

- CTI snow compaction gauge (Michigan)

- Micro tools-assorted small shear vanes and hardness penetrometers (Montana and Michigan)

Mechanical measurements for soft snow:

- Rammsonde penetrometer (ram) (Montana and Michigan)

- SnowMicroPenetrometer (SMP) (Montana)

- Yamaha drop cone (Michigan)

- MagnaProbe (Michigan)

- Plate sinkage (Montana and Michigan)

- Micro tools-assorted small shear vanes and hardness penetrometers (Montana and Michigan)

Additional physical and optical measurements and tests: 
- Air temperature (Montana and Michigan)

- Snow temperature, at surface and with depth, where possible (Montana and Michigan)

- Weight-based snow density (soft snow Montana, soft and groomed snow Michigan)

- Finnish fork snow moisture and density (Montana and Michigan)

- Denoth meter snow moisture (Montana and Michigan)

- Near-infrared (NIR) Photography

- $500 \mathrm{MHz}$ and $1 \mathrm{GHz}$ ground-penetrating radar (GPR) (Montana)

- Spectral reflectance from 350 to $2500 \mathrm{~nm}$ (Montana and Michigan)

- WV2/WV3 satellite imagery (Montana and Michigan)

- TSX satellite imagery (Montana and Michigan)

Several of the measurements were accomplished by digging snow pits. Snow pits allowed snow samples to be taken throughout the depth of virgin snow for direct measurement of snow density; depth profiling of moisture content (using the Finnish fork and Denoth meter) and temperature measurements were taken in the walls of each pit. We also used some of the smaller mechanical measurements, grouped together and called micro tools, in the walls of snow pits to obtain strength profiles.

\subsection{Mechanical measurements for groomed snow}

\subsubsection{Field California Bearing Ratio (CBR)}

CBR is a load-deformation test performed in the field or laboratory. The results are used with empirical design charts to determine the thickness of flexible pavement, base, and other layers for a given vehicle loading and number of passes. The U.S. Army Corps of Engineers (USACE) adopted the CBR method of design for flexible airfield pavements in the 1940s; and today the USACE, U.S. Navy, and U.S. Air Force design practice for surfaced and unsurfaced airfields is still based on CBR (U.S. Army and Air Force 1994).

The field CBR test procedure is described in ASTM International D442909a, Standard Test Method for CBR (California Bearing Ratio) of Soils in Place (ASTM 2010) and in Army Field Manual (FM) 5-530, Materials Testing (U.S. Army et al. 1987). The CBR test is performed by measuring the penetration resistance of a 1.954 in. $(5.0 \mathrm{~cm})$ diameter $\left(3\right.$ in. ${ }^{2}\left[19 \mathrm{~cm}^{2}\right]$ end area) cylindrical steel piston advanced into the soil at a rate of $0.05 \mathrm{in} . / \mathrm{min}(1.27 \mathrm{~mm} / \mathrm{min})$. CBR test parameters are in English units as 
the equipment was developed in the 1940s. The reaction force is measured by means of a calibrated proving ring at increments of $0.025 \mathrm{in}$. (0.635 mm) until reaching a total penetration of 0.500 in. $(12.7 \mathrm{~mm})$. Using field CBR on groomed snow surfaces (Figure 6) is an uncommon application of the test.

Figure 6. Field CBR test setup in Michigan.

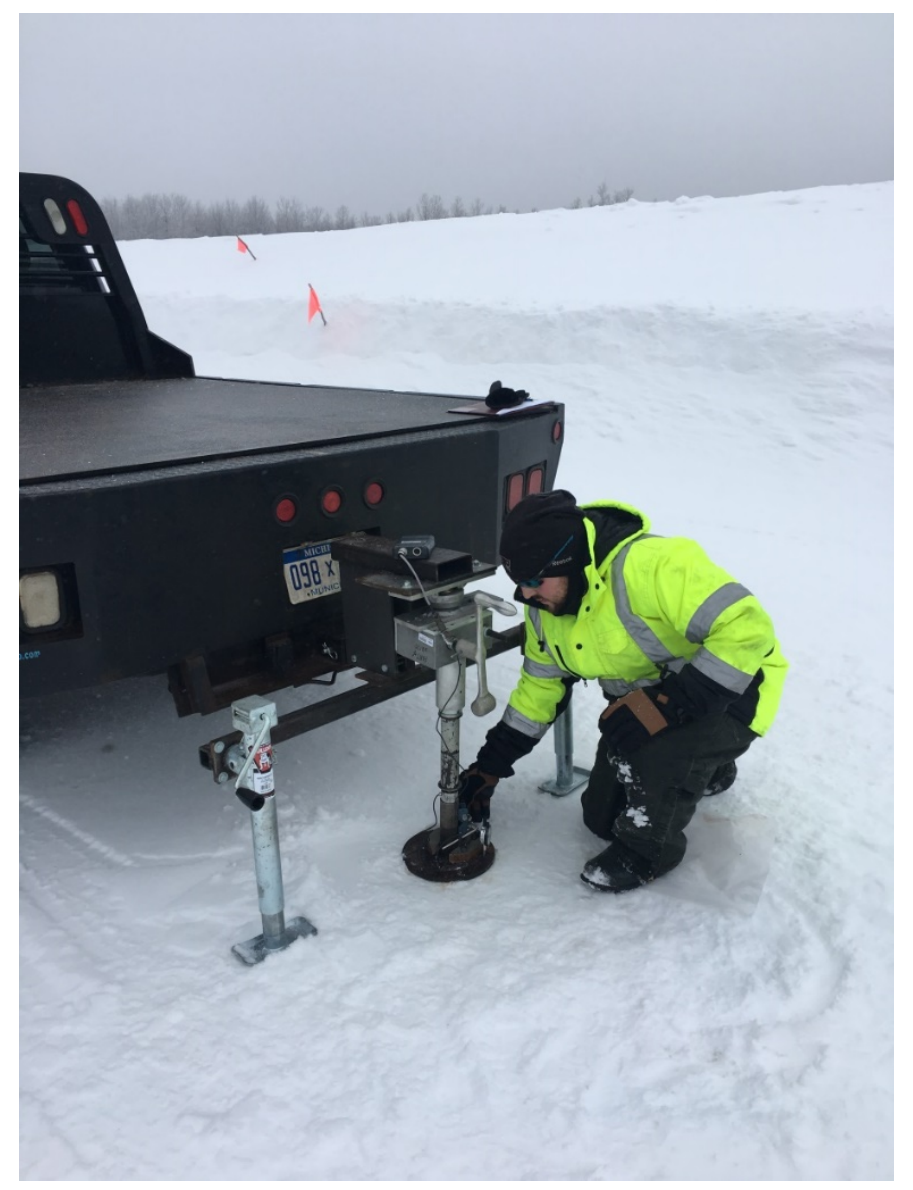

The CBR is reported as a percentage from o to 100 where standard stress values are based on crushed, well-graded (passing through a 3/4 in. [19.0 mm] sieve) limestone serving as the $100 \%(\mathrm{CBR}=100)$ material. The stress penetration curves are calculated using the force divided by the piston area. The corrected stress values for $0.10 \mathrm{in}$. and $0.20 \mathrm{in} .(2.54 \mathrm{~mm}$ and $5.08 \mathrm{~mm}$ ) penetration taken from stress-penetration curves are divided by 1000 psi and 1500 psi (6.9 MPa and 10.3 MPa), respectively, the reference value for limestone, and then multiplied by 100 to determine the CBR values. The bearing ratio that is reported for the soil is the ratio determined from the 0.10 in. $(2.54 \mathrm{~mm})$ penetration; however, if the bearing ratio measured at $0.20 \mathrm{in} .(5.08 \mathrm{~mm})$ penetration is greater than that of the 
0.10 in. $(2.54 \mathrm{~mm})$ penetration, the test must be rerun. If the ratio determined using the 0.20 in. $(5.08 \mathrm{~mm})$ penetration is still greater again in the second test, the bearing ratio at 0.20 in. $(5.08 \mathrm{~mm})$ penetration should be used as the CBR value (ASTM 2010).

\subsubsection{Cleggs}

The Clegg Impact Hammer consists of a cylindrical mass hammer that is dropped within a guide tube from a set height (Clegg 1980; ASTM 2016a). The hammer is equipped with an accelerometer that measures the peak deceleration on impact in gravity units. The hammer is dropped four times at each location, and deceleration readings are recorded for each drop (Figure 7). The readings are reported in 1/10 g-forces. Typically, both the $2.25 \mathrm{~kg}(5.0 \mathrm{lb})$ and the $0.5 \mathrm{~kg}(1.1 \mathrm{lb})$ size Cleggs are typically used to measure natural ground or uncompacted soil surfaces. Shoop et al. (2012) provides a good summary and background on the different Clegg sizes, their use for snow-strength measurement, and conversion to other strength parameters.

Figure 7. The $0.5 \mathrm{~kg}$ Clegg.

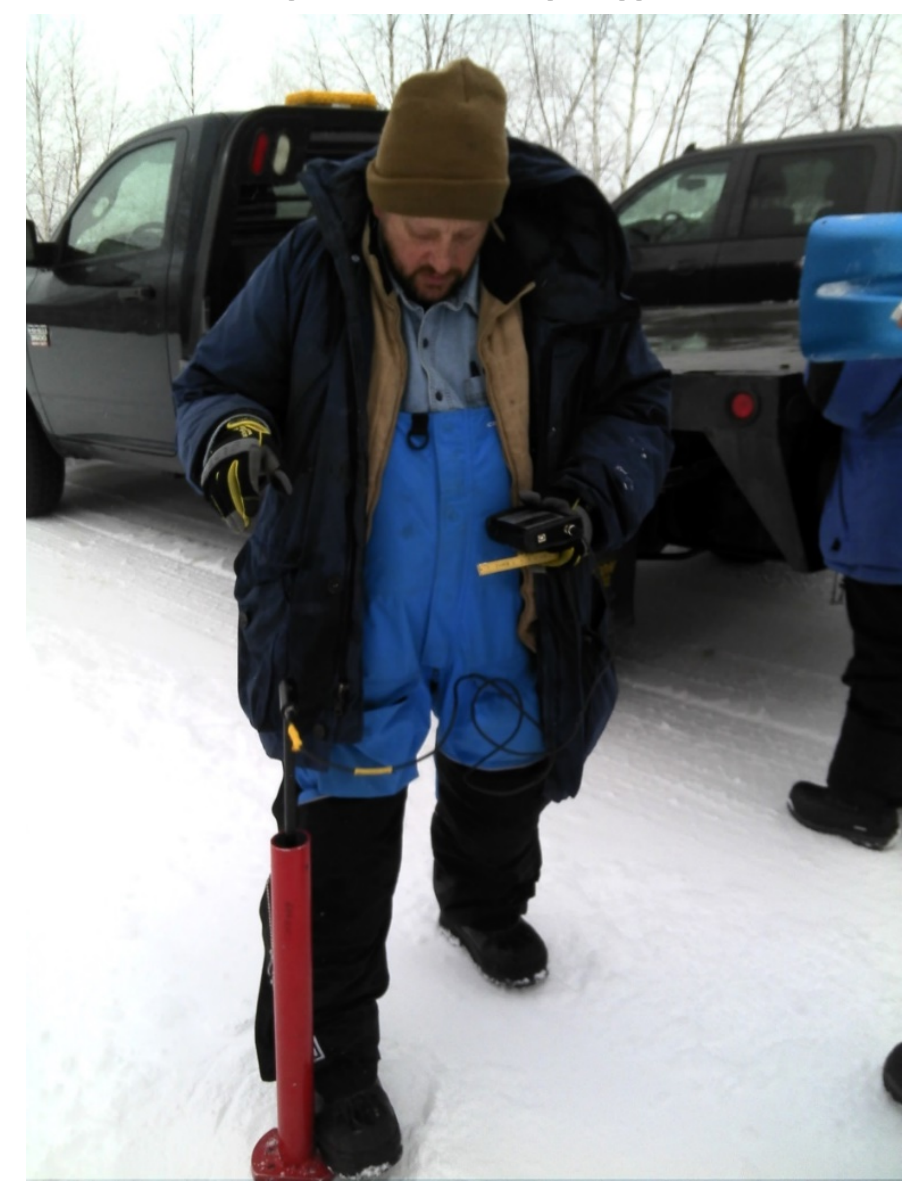


Clegg measurements were taken at each site using both the $2.25 \mathrm{~kg}$ ( $5.0 \mathrm{lb})$ and the $0.5 \mathrm{~kg}(1.1 \mathrm{lb})$ weight hammers. If a groomed snow site had received fresh snow, two sets of measurements were taken; one on top of the fresh snow and one on the underlying groomed surface after brushing off the surface.

Clegg Impact Values (CIVs) for each site were taken as the average measurement of the third drop for the $2.25 \mathrm{~kg}$ (5.0 lb) Clegg and the fourth drop for the $0.5 \mathrm{~kg}(1.1 \mathrm{lb})$ Clegg. CIV values were converted to CBR following equation (1) for the $2.25 \mathrm{~kg}(5.0 \mathrm{lb})$ Clegg data and equation (2) for the 0.5 $\mathrm{kg}(1.1 \mathrm{lb})$ Clegg data (Shoop et al. 2012; Millar 1977):

$$
\begin{aligned}
& C B R(\%)=e^{\frac{10 C I V_{2.25 \mathrm{~kg}}-14.936}{79.523}} . \\
& C B R(\%)=0.55 C I V_{0.5 \mathrm{~kg}}-1 .
\end{aligned}
$$

\subsubsection{Light Weight Deflectometer (LWD)}

The LWD is a portable version of the larger, typically trailer-mounted, falling weight deflectometer (FWD). It was developed to estimate the in situ stiffness modulus of soils and is often used for quality control/quality assurance and structural evaluation of mechanically compacted earthwork and pavement construction (Senseney and Mooney 2010). With its proprietary software, the LWD may be used to backcalculate the soil elastic modulus for known one- and two-layer stratigraphy by using the deflection data measured by three geophones (seismic transducers), one at the center of the loading plate and two offset radially beyond the edge of the plate. It can also be used in single geophone mode to calculate an Impulse Stiffness Modulus (ISM).

The Dynatest 3031 LWD device consists of a weight dropped from increasing heights along a guide rod. The weight makes contact with a rubber buffer, and the load is transferred to the soil surface via a $300 \mathrm{~mm}$ (11.8 in.) diameter loading plate. The surface response from the load impact generates a vertical deflection response measured (through integration of velocity) with one or three geophones. One geophone was centrally located on the loading plate; the other two are external and were not used on snow for this project as they did not register a signal on the groomed snow surfaces. The geophone response is reported as deflection in mils 
(1/1000 in.). The LWD tests performed for this program typically had 16 drops per test point (Figure 8). More information of the procedures developed under BAEM for using the LWD on winter surfaces is presented in Wieder et al. (2019) and Menke et al. (2019).

Figure 8. The LWD.

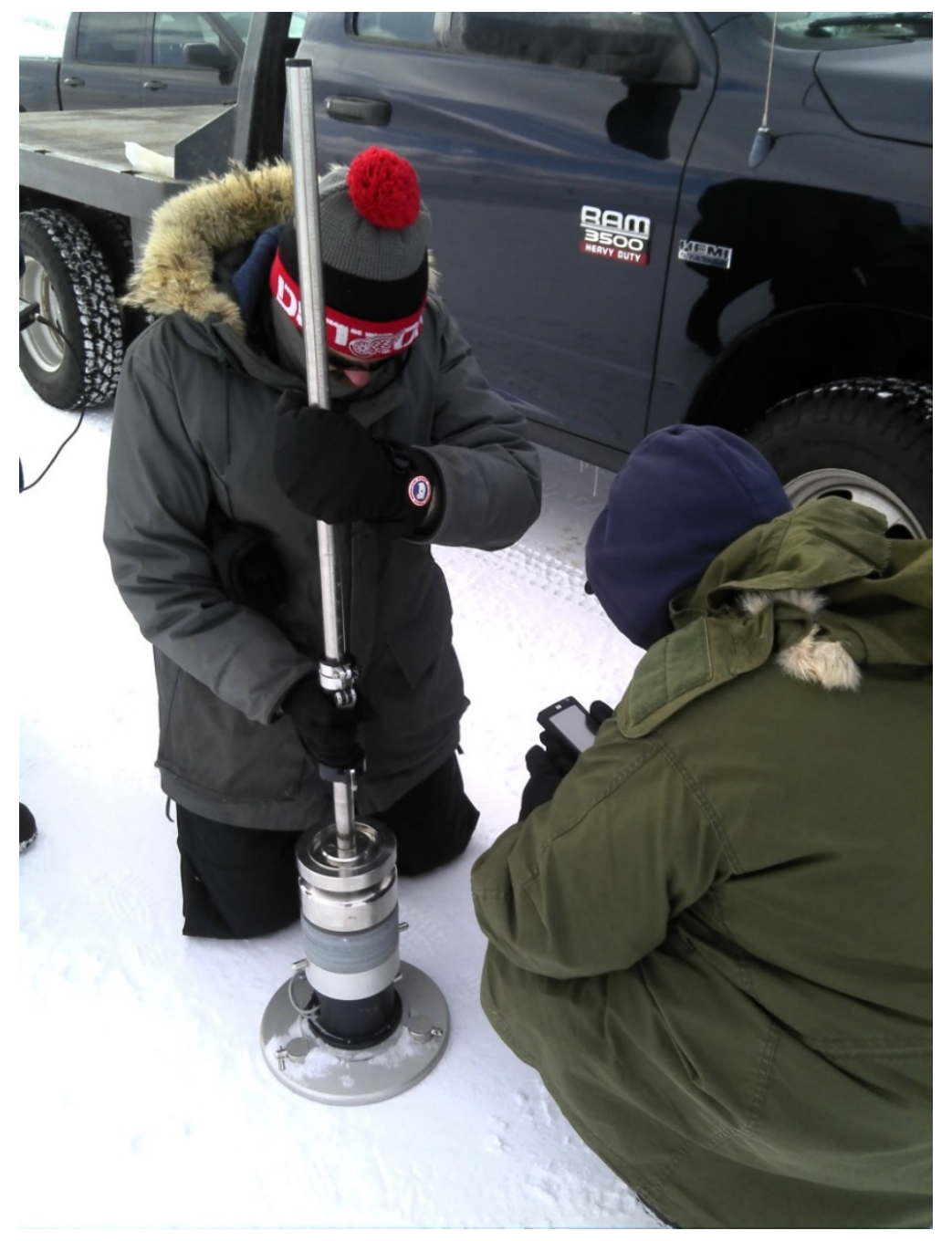

\subsubsection{Russian Snow Penetrometer}

Though similar to the ram in operation, the RSP (Figure 9), was designed for testing compacted snow (Blaisdell et al. 1995). The RSP has a $30^{\circ}$ cone tip with a maximum diameter of $1.15 \mathrm{~cm}$ (0.45 in.) and uses a $1.75 \mathrm{~kg}(3.9$ lb) hammer dropped from a height of $50 \mathrm{~cm}(19.7 \mathrm{in}$.) to drive a $1.421 \mathrm{~kg}$ (3.1 lb) penetrometer (with tip). In this study, RSP penetration depth was noted every 1-2 hammer blows and ranged from a o to $320 \mathrm{~mm}$ (o to 12.6 in.) penetration depth per reading, depending on the strength of the 
snow. RSP hardness is calculated using the same equations as the one developed for the ram, discussed in section 3.2.1

Figure 9. RSP in use in Michigan.

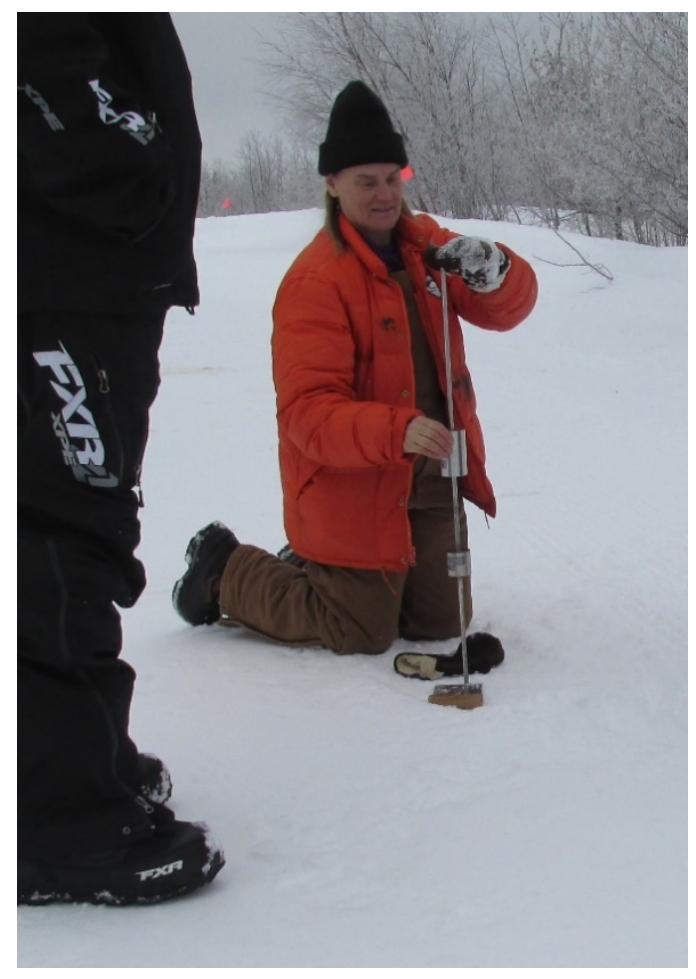

\subsubsection{CTI}

The CTI snow compaction gauge (Figure 10), manufactured by Smithers Rapra, is shaped like a surveyor's plumb bob (cone) except that the point is rounded with a $1.6 \mathrm{~mm}$ (1/16 in.) radius. Each gauge is adjusted in the laboratory to have a weight of $220 \pm 1 \mathrm{~g}(0.485 \pm 0.002 \mathrm{lb})$, including the knurled nut on top of the drop rod. The drop height is set to $218.9 \pm 0.25$ $\mathrm{mm}(8.92 \pm 0.01 \mathrm{in}$.$) .$

In use, the mass of the cone and rod is dropped a preset distance through a guide tube. The kinetic energy is expended in both vertical penetration and side compression.

The penetration distance is measured using a calibrated scale to directly read the hardness of the snow surface as a standardized index with values ranging from 50-100 CTI (ASTM 2016b). 
Figure 10. CTI test in Michigan.

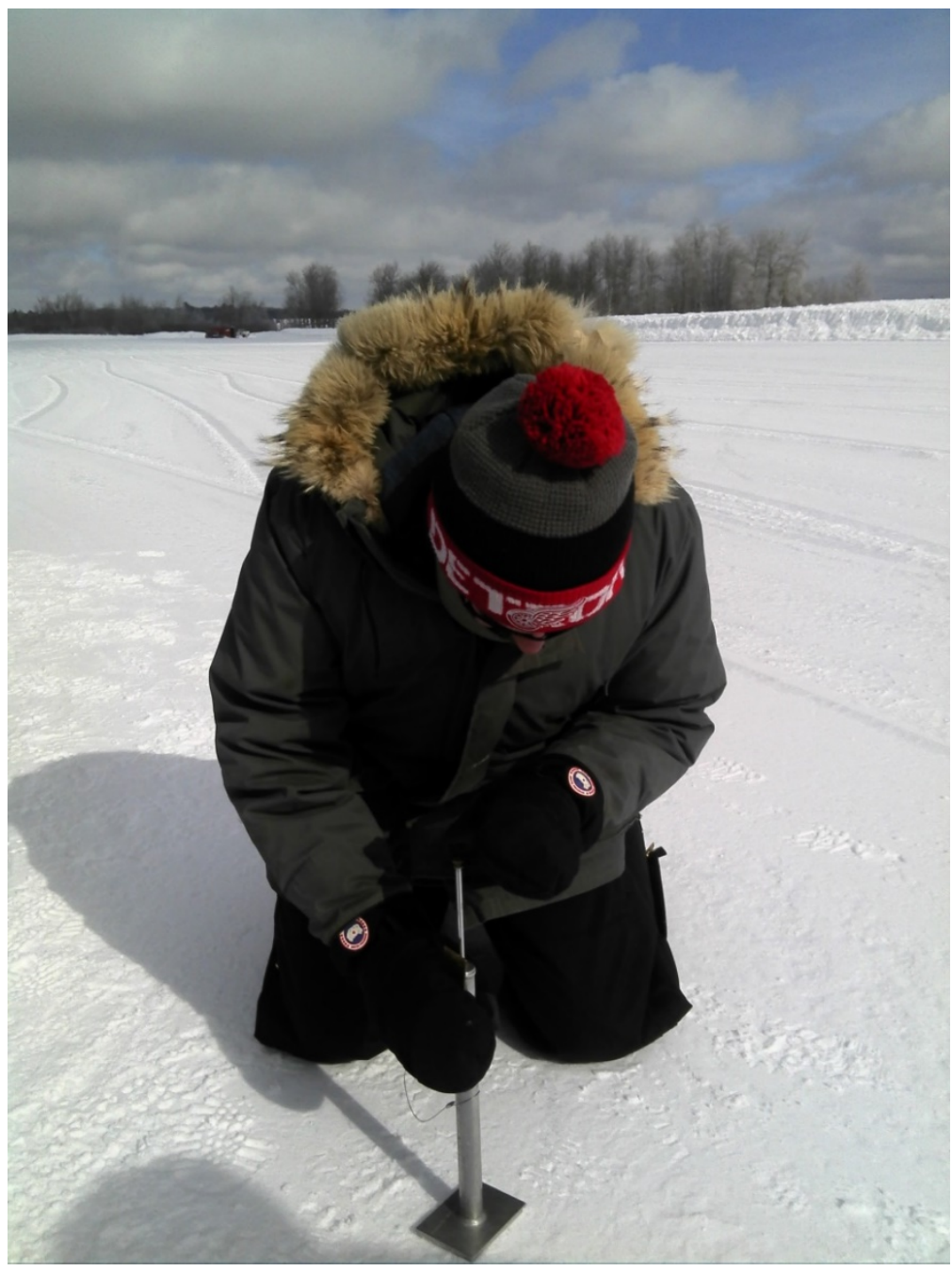

\subsubsection{Micro tools}

\subsubsection{Pocket penetrometer}

The Geotester dial penetrometer (henceforth pocket penetrometer) is designed for use on cohesive soils. It estimates the unconfined compressive strength of the soil surface in kilograms per square centimeter when used with the standard $6.35 \mathrm{~mm}$ (0.25 in.) diameter plunger. Four larger plungers of 10, 15, 20, and $25 \mathrm{~mm}(0.39,0.59,0.79$, and $0.98 \mathrm{in}$.) in diameter can provide strengths over a wide range of soil types.

The plunger of the pocket penetrometer was pressed into the snow until the snow collapsed or to the depth of the calibration notch. The penetrometer was withdrawn from the snow with the test value, in kilograms, retained on the dial. Dial readings were manually recorded and later 
converted to bearing capacity by using calibration charts provided by the manufacturer (AMS 2018). As snow strength varied considerably between sites, different plunger sizes were used. After selecting an appropriate plunger size, three measurements, or more if readings were inconsistent, were taken at each site and were averaged.

\subsubsection{Shear vane}

Measurements of surface shear strength were made using a Geonor H-6o handheld vane tester (henceforth shear vane). The shear vane has an orthogonal, cross-shaped blade. The vane blade comes in three standard sizes, and the size is chosen based on the snow strength. Custom vane sizes may also be used when snow conditions are either too hard or too soft for the standard vanes. The vane is inserted into the snow to a depth covering the entire vane, and then a steady turning force is applied until the snow shears. The maximum shear force is recorded as kilopascals. The shear strength values for each site are the average of three measurements. ASTM D2573-18 (ASTM 2018) covers the use of the shear vane in soils.

\subsubsection{Snow hardness plates}

Plates of various sizes can be used to assess snow hardness. This tool was most useful on horizontal surfaces, such as the snow surface, and for characterizing the hardness of interspersed snow or ice layers.

\subsection{Mechanical measurement for soft snow}

\subsubsection{Rammsonde}

The Rammsonde is used to measure the penetration resistance of the snow, called a ram hardness. The ram hardness of snow is an indication of the resistance of snow to vertical penetration by a cone tip driven by the force of a weight dropped from a known height (Abele 1990). Ram hardness is significantly correlated with unconfined compressive strength (Abele 1963) and with shear strength (Abele 1968), and ram hardness is linearly correlated with CBR (Abele 1990). Successive drops and notation of penetration distance can provide a profile of ram hardness through the snowpack.

The ram used in this study (Figure 11) was equipped with a $30^{\circ}$ cone tip (2.4 cm [0.9 in.] diameter, $3.9 \mathrm{~cm}$ [1.5 in.] height, and $5 \mathrm{~cm}$ [2.0 in.] total length), typically used on groomed snow surfaces (snow roads and airfields). A 0.5, 1.0, or $3.00 \mathrm{~kg}(1.1,2.2$, or $6.6 \mathrm{lb})$ weight was dropped from a 
height of 10 to $50 \mathrm{~cm}$ (3.9 to 19.7 in.) above the snow surface to drive the $1.02 \mathrm{~kg}(2.2 \mathrm{lb})$ penetrometer. Drop weights and heights were adjusted to achieve penetrations less than $2 \mathrm{~cm}$ ( $0.8 \mathrm{in}$.) for each recorded interval, although this was usually not possible for virgin snow.

Figure 11. Ram testing in Michigan.

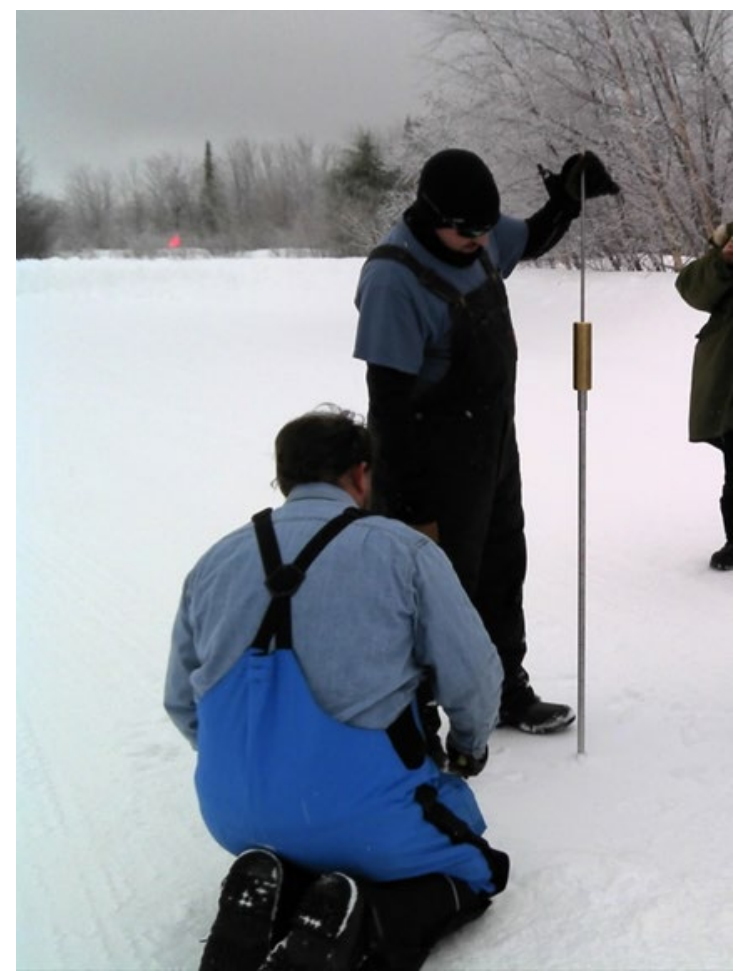

The ram hardness $(R, \mathrm{kgf})$ is calculated as

$$
R=\frac{W h n}{x}+W+Q
$$

where

$$
\begin{aligned}
W & =\text { the mass of the drop hammer } \\
h & =\text { the height of the drop, } \\
n & =\text { the number of blows, } \\
x & =\text { the penetration after } n \text { blows, and } \\
Q & =\text { the mass of the penetrometer. }
\end{aligned}
$$

Calculated $R$ is multiplied by a factor of 1.56 to convert to $R$ values using the standard $60^{\circ}$ cone tip, more commonly used in avalanche studies (Abele 1990). Further, to correct for the conical tip and proximity of a free surface, $R$ values are corrected by a factor of 4.0 from a 0 to $5 \mathrm{~cm}$ (o to 
2.0 in.) depth and by a factor of 1.6 from a 5 to $10 \mathrm{~cm}$ (2.0 to $3.9 \mathrm{in}$.) depth (Abele 1990).

\subsubsection{SnowMicroPenetrometer}

The SMP is a mechanically driven sonde penetrometer used to measure the hardness of the snowpack as a multimodal penetration force. The SMP has a $60^{\circ}$ cone with a base diameter of $5 \mathrm{~mm}$ (0.2 in.). This instrument samples the penetration force 250 times per millimeter and drives through the snowpack with a strain rate above $10^{-3}$ such that the snow behaves nearly linear elastically with brittle failure (Marshall and Johnson 2009). Thus, in theory, the SMP is capable of measuring the individual ruptures of snow crystals that are in contact with the penetrometer tip. The SMP was designed to operate in light alpine snowpacks and to be sensitive to structural weaknesses within the snowpack to assess avalanche hazard (Schneebeli and Johnson 1998).

The standard SMP sensor is sensitive to a range of forces between $\mathrm{o}$ and $42 \mathrm{~N}$ (9.4 lbf) (Pielmeier and Schneebeli 2003). For the Montana campaign, the SMP was equipped with an alternative force sensor, enabling the SMP to measure forces up to $250 \mathrm{~N}(56.2 \mathrm{lbf})$. The increased dynamic force range comes at a cost in force resolution as the instrument's discrete quantization levels were not increased when the sensor capacity was increased. Meehan et al. (2019a, 2019b) document and analyze the SMP, its use, and results. While this instrument worked very well in the soft snow conditions it was designed for, future experiments would benefit from an SMP that could measure larger forces as many of the groomed surfaces were too hard for this instrument even with the larger force sensor.

\subsubsection{Yamaha drop cone}

The Yamaha drop cone (Figure 12) is an aluminum cone that is dropped from a specific height onto ungroomed snow. The resulting depth of penetration into the snow is then measured. Figure 13 provides a schematic for the Yamaha drop cone. 
Figure 12. Yamaha drop cone in use in Michigan.
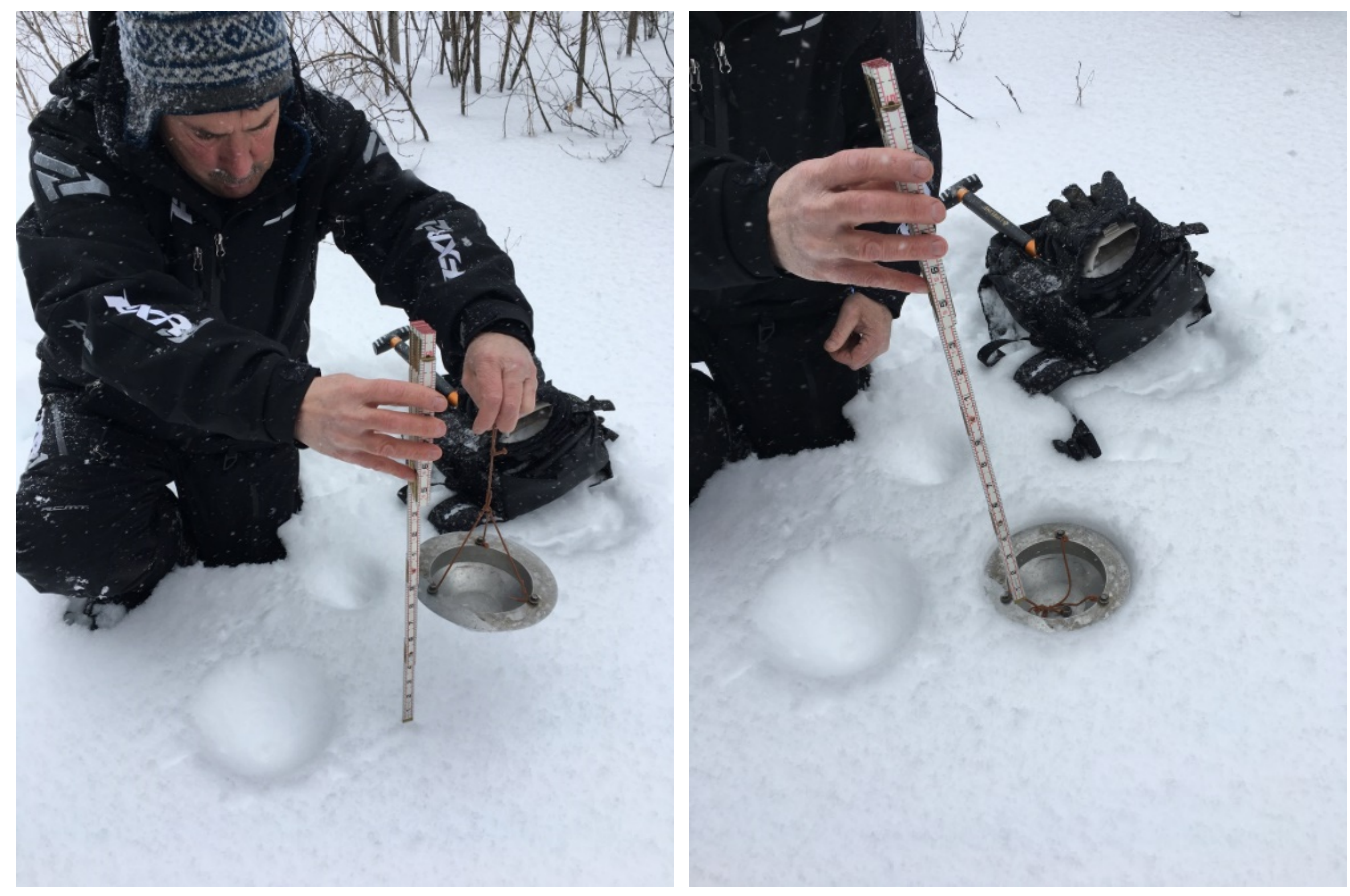

Figure 13. Yamaha drop cone schematic and specifications.

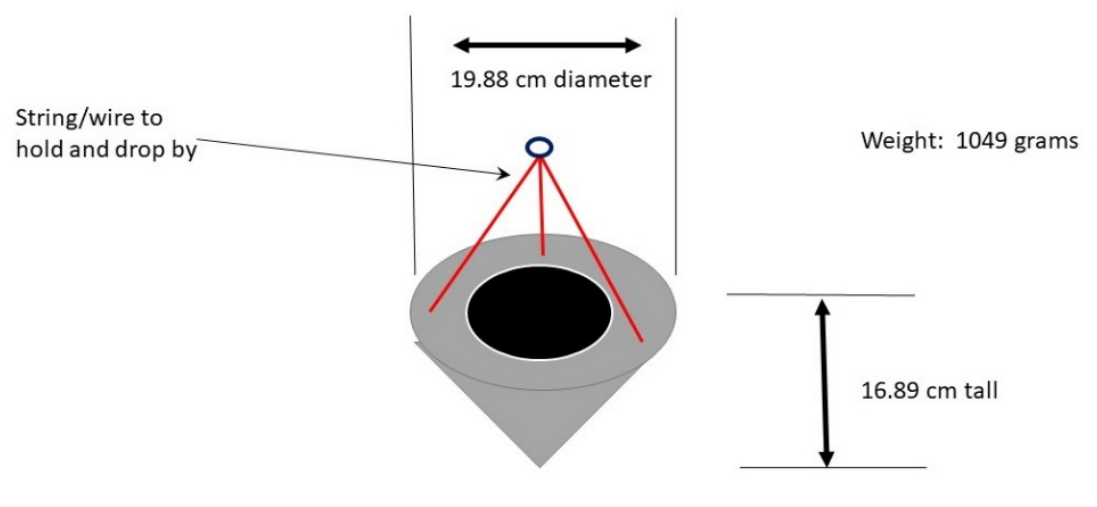

Aluminum

\section{Yamaha Drop Cone}

\subsubsection{MagnaProbe}

The MagnaProbe (Figure 14), manufactured by Snow-Hydro, is a self-recording snow-depth probe that interfaces with a GPS (global positioning system) for geolocation (Sturm and Holmgren 1999). The MagnaProbe

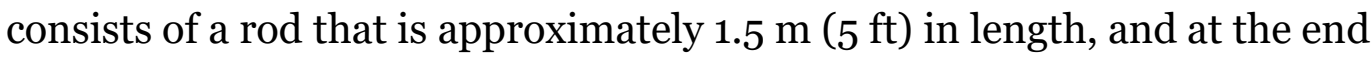
of the probe is a white basket that will ride on the top of the snowpack. The control button at the top of the probe is pushed to record the snow-depth 
measurement and GPS location. Data are recorded by a Campbell Scientific datalogger. Accuracy of the GPS is $\pm 10 \mathrm{~m}$ (33 ft) absolute and $\pm 2 \mathrm{~m}$ $(6.5 \mathrm{ft})$ relative on repeated surveys. Using this probe, an operator can walk across a snow-covered landscape and in several hours produce a detailed transect of snow depths.

Figure 14. Snow MagnaProbe.

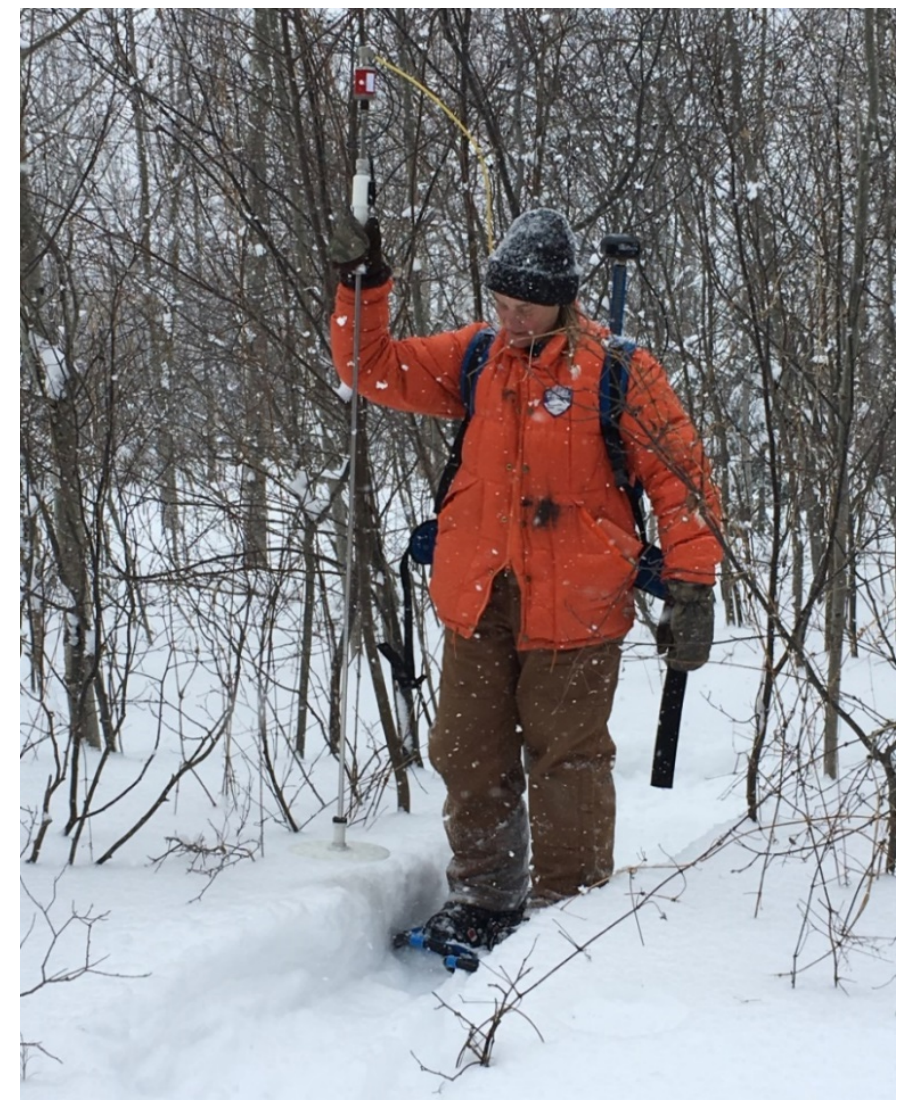

\subsubsection{Plate sinkage}

Prior to deployment for the 2018 BAEM field campaign, CRREL engineers manufactured a prototype plate sinkage device (Figure 15). The intent of the device was to characterize virgin snow strength by measuring the force required to drive, by hand, plates of different diameters through the snow. 
Figure 15. Plate sinkage test in Michigan.

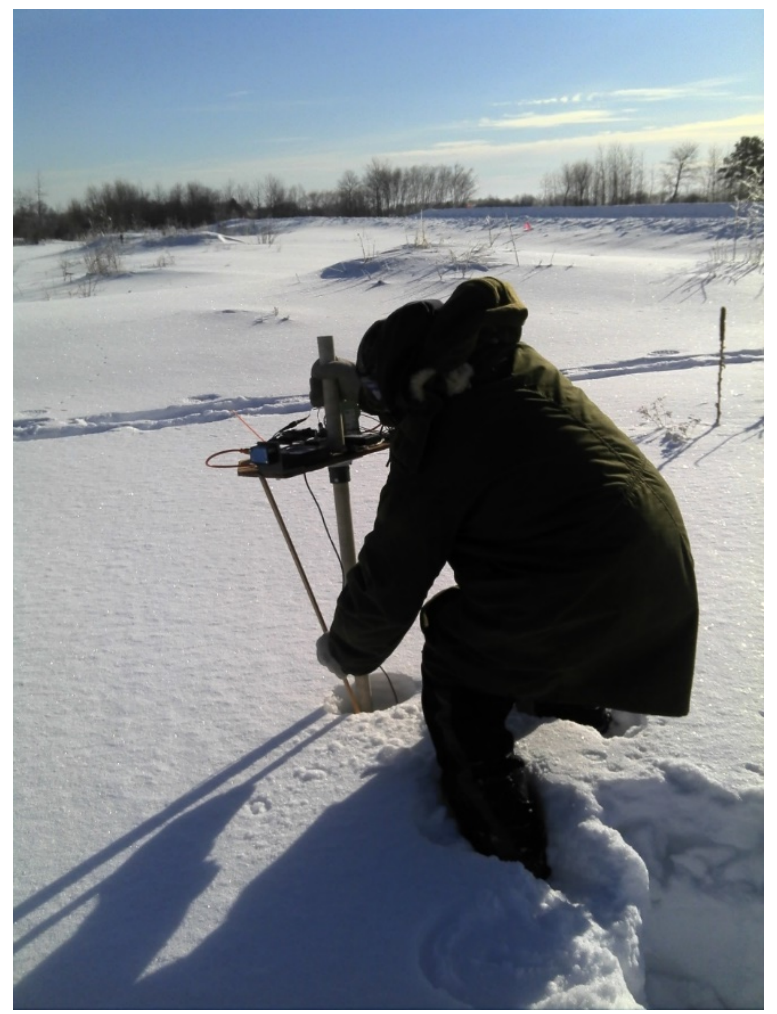

\subsection{Additional physical and optical measurements}

\subsubsection{Air and snow temperatures}

Weather data from nearby weather stations were collected (Appendix C). In addition, temperatures at $15 \mathrm{~cm}$ (6 in.) above the surface, at the surface, and $2.5 \mathrm{~cm}$ ( 1 in.) below the surface were also recorded. In the fresh and virgin snowpacks, temperatures within the snow were recoded every $10 \mathrm{~cm}$ (4 in.) in the walls of each snow pit.

\subsubsection{Snow density}

Two different methods of snow-density measurements were required for the soft and groomed snow surfaces encountered in both Montana and Michigan.

For virgin snow, density was measured by taking samples of the snow using a cutting tool (Conger and McClung 2009; Carroll 1977). This was done by shoveling a pit in the snow down to the ground surface. The pit walls were shoveled as neatly and as near vertical as possible. At regular intervals, a $100 \mathrm{~cm}^{3}$ stainless steel cutter was inserted horizontally and a rec- 
tangular block of snow extracted (Figure 16). The rectangular block of snow was weighed to calculate the density of that layer.

Figure 16. Snow-density-sample extraction in a snow pit.

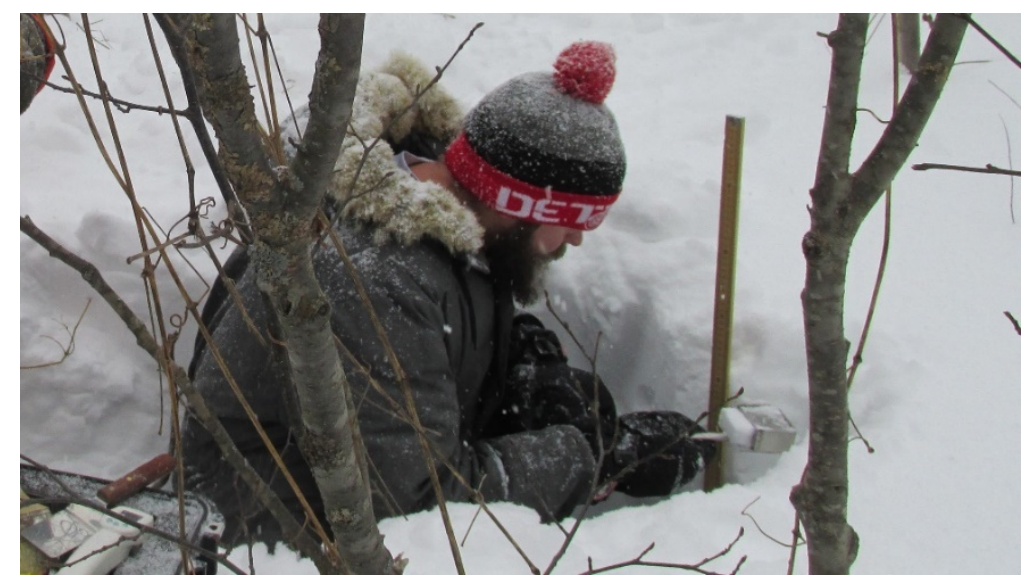

For the denser snow surfaces, when the snow was too hard to take a sample without damaging the cutter (densities greater than approximately $0.5 \mathrm{~g} / \mathrm{cm}^{3}\left[0.018 \mathrm{lb} / \mathrm{in}^{3}\right]$ ), another method was needed. For these surfaces, we drove a $5.8 \mathrm{~cm}$ ( $2.28 \mathrm{in}$.) diameter cylinder into the surface of the snow down to depths of $2.5,5.0$, and $7.6 \mathrm{~cm}(1,2$, and 3 in.), Figure 17, and carefully removed the sample. This sample was weighed, the volume calculated, and the resultant density recorded. This technique, developed by Russ Alger at KRC, was used at the Michigan site only.

Figure 17. Snow-density test using the aluminum cylinder in Michigan.

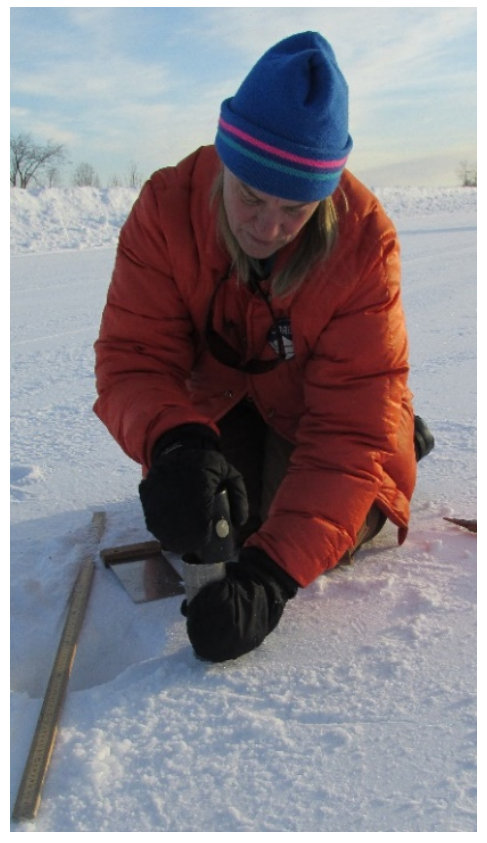




\subsubsection{Denoth meter}

The Denoth snow moisture meter is an electronic dielectric device that measures the real part of the dielectric constant of snow at $20 \mathrm{MHz}$ by using a capacitance plate. Empirical relationships with snow moisture and density, which must be measured separately, allow the calculation of snow-volume wetness (Denoth 1989). These measurements were taken in snow pit walls at a $10 \mathrm{~cm}$ (4.0 in.) spacing. On the surface of the snow, the unit can be used to make a half-space measurement. Measurements within $5 \mathrm{~cm}$ (2.0 in.) of the ground are affected by the dielectric properties of the underlying ground surface and should be interpreted with caution.

\subsubsection{Finnish snow fork}

The Toikka Oy snow fork, commonly referred to as the Finnish snow fork, measures the real and imaginary components of the dielectric constant of snow by using microwave resonance in the range of 500 to $900 \mathrm{MHz}$. The dielectric constant can be related to snow density and liquid water content through semiempirical relationships (Tiuri and Sihvola 1986). We used the snow fork to measure density and liquid water content (wetness) at $5 \mathrm{~cm}$ (2.0 in.) depth intervals in the sidewall of the pits dug through the snow down to the terrain surface. Note that, unlike the Denoth meter, the snow fork does not require an additional density observation. However, similar to the Denoth meter, observations within $5 \mathrm{~cm}$ (2.0 in.) of the ground will be influence by the ground conditions and should be interpreted with caution.

\subsubsection{NIR photography}

NIR photographs were taken with a Canon DSLR camera that was modified to capture broadband light and was outfitted with an 800-1100 $\mathrm{nm}$ filter on the lens. At these wavelengths, the snow's reflectance significantly depends on grain size and microstructure (Matzl and Schneebeli 2006). This technique allows mapping of the stratigraphic layers identified in snow pits.

\subsubsection{GPR}

A Sensors \& Software Inc. $1 \mathrm{GHz}$ GPR was operated in the virgin snow, vehicle belly drags, and tire ruts during the Montana field work. A broadband wave pulse is transmitted by the GPR into the snow and echoes from stratigraphic layers within the snow and the snow-ground interface. The reflected energy (echoes) are sensed by the receiving antenna and digitized to create the GPR image. The transmitting and receiving antennas are 
housed independently such that the horizontal separation (offset) between them can be varied. The antennas were placed on the snow surface, and their offset was expanded incrementally to a maximum separation of $2 \mathrm{~m}$. The travel times associated with the GPR wave reflection off of the snowground interface measured at the various offsets are used to estimate the dielectric constant of the snow. Similar to the function of the Finnish snow fork, the dielectric permittivity is related to the snow density, which can be used as a proxy for snow strength. We have not fully evaluated data from the GPR at this time.

\subsubsection{Nadir spectral reflectance}

We took field spectral measurements using an ASD manufactured by Malvern Panalytical Ltd (Figure 18). Reflectance measurements from 350 to $2500 \mathrm{~nm}$ with $3-8 \mathrm{~nm}$ of spectral resolution were collected at target locations on a variety of surfaces, including asphalt, ice, packed snow, and fresh natural snow. A 5-degree field of view foreoptic was used. The spectral signature from a given surface at nadir (i.e., the ASD probe pointed vertically down at the surface) and the spectral signature at nadir from a white Spectralon reference plate were measured at each site. The spectral reflectance was calculated by dividing the surface measurement by the reference standard measurement.

Figure 18. ASD taking a datum measurement in Michigan.

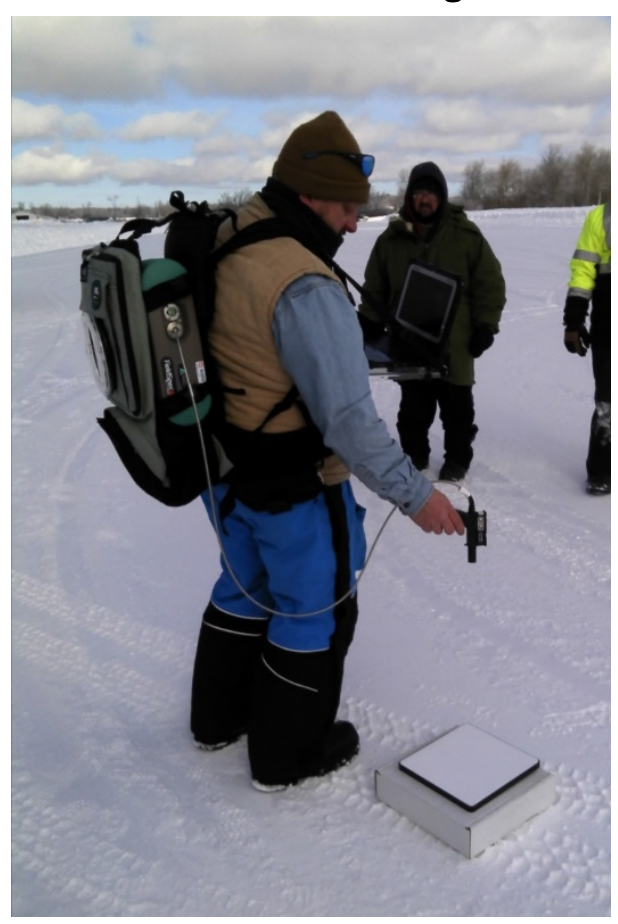




\subsubsection{Satellite imagery}

This project used Digital Globe's WorldView-2 and -3 (WV2 and WV3) satellite imagery to study the different winter surfaces. WV2's 8 multispectral bands range from 0.4 to $1.04 \mu \mathrm{m}$ and are typically used for vegetation, coastal, and land-use mapping (Kruse 2015). WV3 senses the same 8 multispectral (MS) bands as WV2 plus 8 shortwave infrared (SWIR) bands ranging from 1195 to $2365 \mathrm{~nm}$ and 12 clouds, aerosols, vapors, ice, and snow (CAVIS) bands ranging from 405 to $2245 \mathrm{~nm}$ (Table 4).

Table 4. WV3 sensing bandwidths (DigitalGlobe 2012, 2014).

\begin{tabular}{|c|c|c|}
\hline Band & Description & Wavelength (nm) \\
\hline Panchromatic* & & $450-800$ \\
\hline MS1 $^{*}$ & Coastal & $400-450$ \\
\hline MS2* $^{*}$ & Blue & $450-510$ \\
\hline MS3* $^{*}$ & Green & $510-580$ \\
\hline $\mathrm{MS}^{*}$ & Yellow & $585-625$ \\
\hline $\mathrm{MS}^{*}$ & Red & $630-690$ \\
\hline $\mathrm{MS6}^{*}$ & Red Edge & $705-745$ \\
\hline $\mathrm{MS7}^{*}$ & NIR1 & $770-895$ \\
\hline MS8* & NIR2 & $860-1040$ \\
\hline SWIR1 & & $1195-1225$ \\
\hline SWIR2 & & $1550-1590$ \\
\hline SWIR3 & & $1640-1680$ \\
\hline SWIR4 & & $1710-1750$ \\
\hline SWIR5 & & $2145-2185$ \\
\hline SWIR6 & & $2185-2225$ \\
\hline SWIR7 & & $2235-2285$ \\
\hline SWIR8 & & $2295-2365$ \\
\hline CAVIS1 & Desert Clouds & $405-420$ \\
\hline CAVIS2 & Aerosol 1 & $459-509$ \\
\hline CAVIS3 & Green & $525-585$ \\
\hline CAVIS4 & Aerosol 2 & $635-685$ \\
\hline CAVIS5 & Water 1 & $845-885$ \\
\hline CAVIS6 & Water 2 & $897-927$ \\
\hline CAVIS7 & Water 3 & 930-965 \\
\hline CAVIS8 & NDVI SWIR ${ }^{\dagger}$ & $1220-1252$ \\
\hline CAVIS9 & Cirrus & $1365-1405$ \\
\hline CAVIS10 & Snow & $1620-1680$ \\
\hline CAVIS11 & Aerosol 1 & $2105-2245$ \\
\hline
\end{tabular}

* Indicates bands included in WV2. WV2 has a panchromatic band $(\sim 0.46 \mathrm{~m}$ resolution at nadir) and 8 multispectral bands ( $\sim 1.85 \mathrm{~m}$ resolution at nadir). WV3 has a panchromatic band ( $\sim 0.31 \mathrm{~m}$ resolution at nadir), 8 multispectral bands $(\sim 1.24 \mathrm{~m}$ resolution at nadir), 8 SWIR bands ( $\sim 3.70 \mathrm{~m}$ resolution at nadir), and 12 CAVIS bands ( $\sim 30 \mathrm{~m}$ resolution at nadir).

$\dagger$ NDVI = Normalized Difference Vegetation Index; SWIR = Short Wave Infrared 
These CAVIS bands help to mitigate effects caused by the atmosphere, and the SWIR bands allow for a closer look at surface materials that present unique reflectance and absorption features (Longbotham et al. 2014). $\mathrm{WV}_{3}$ also has higher spatial resolution than $\mathrm{WV} 2$, as indicated in the footnote of Table 4 (Digital Globe 2014).

TSX is not optical imagery but is an X-band radar imaging system. TSX satellite acquisitions were collected at the highest spatial resolution $(\sim 0.25 \mathrm{~cm}[\sim 0.98 \mathrm{in}]$.$) , resulting in a single horizontally polarized$ backscatter image.

CRREL requested remote imagery for both $\mathrm{WV}_{3}$ and TSX during the onsite collections. Over the course of this study, one WV2 and two $\mathrm{WV}_{3}$ collections were acquired from Digital Globe. The WV2/WV3 collections took place on 24 February 2018 (Montana) and 26 February and 16 March 2018 (Michigan). TSX satellite imagery collections took place on 27 January 2018 (Montana) and on 21 February 2018 (Michigan). All satellite imagery was geographically referenced, and the WorldView images were atmospherically corrected.

\subsection{Data analysis}

We analyzed the mechanical and physical properties and the WorldView data for correlations, analysis of variance, and statistical tests by using R 3.4 (R Core Team 2017). Nonparametric statistical methods were used due to the nonnormality of data typical of some measurement techniques. These include Spearman rank correlation, Kruskal-Wallis one-way analysis of variance, and the Conover-Iman test (Conover and Iman 1979). Linear regression models were built for some log-transformed measurements. Table 5 lists the snow measurements and their units. Appendix D provides tabular summaries of the data. 
Table 5. List of snow characterization parameters used in this study.

\begin{tabular}{|l|c|l|}
\hline \multicolumn{1}{|c|}{ Parameter } & Units & \multicolumn{1}{c|}{ Description } \\
\hline CBR & $\%$ & Field California Bearing Ratio \\
\hline CBR $2.25 \mathrm{~kg}$ & $\%$ & California Bearing Ratio from 2.25 kg Clegg \\
\hline CBR $0.5 \mathrm{~kg}$ & $\%$ & California Bearing Ratio from 0.5 kg Clegg \\
\hline Clegg $2.25 \mathrm{~kg}$ & $\mathrm{CIV}$ & Clegg Impact Value from 2.25 kg Clegg \\
\hline Clegg $0.5 \mathrm{~kg}$ & $\mathrm{CIV}$ & Clegg Impact Value from 0.5 kg Clegg \\
\hline Ram & $\mathrm{kgf}$ & Ram Index (R) \\
\hline RSP & $\mathrm{kgf}$ & RSP Index (R) \\
\hline Pocket Pen. & $\mathrm{kg} \mathrm{cm}{ }^{-2}$ & Pressure from pocket penetrometer \\
\hline LWD ISM & $\mathrm{kips} / \mathrm{in}$. & LWD ISM at four load levels (LL): LL1, LL2, LL3, and LL4 \\
\hline Shear Vane & $\mathrm{kPa}$ & Shear stress at the surface and in virgin snow profiles \\
\hline CTI & $\mathrm{CTI}$ & CTI snow compaction gauge \\
\hline Reflectance Value & & $\begin{array}{l}\text { The fraction of incident light reflected by a surface, a } \\
\text { unitless number (Shaw and Burke 2003) }\end{array}$ \\
\hline Snow Density & $\mathrm{g} / \mathrm{cm}{ }^{3}$ & $\begin{array}{l}\text { Snow density for the top 5 cm and/or average for the } \\
\text { depth of snow at the site }\end{array}$ \\
\hline Air Temperature & ${ }^{\circ} \mathrm{C}$ & Ambient air temperature at the time of testing \\
\hline Snow Temperature & ${ }^{\circ} \mathrm{C}$ & Temperature of the snow at various depths \\
\hline Snow Moisture & $\%$ & Percent by volume \\
\hline Snow Depth & $\mathrm{cm}^{2}$ & Depth of the snow layer \\
\hline Yamaha Drop Cone & $\mathrm{cm}$ & Penetration into snow when dropped from 10 in. height \\
\hline
\end{tabular}




\section{Results and Discussion}

\subsection{General site conditions}

Numerous statistics were calculated to generate information on the general site conditions and to determine which strength measures correlated to standard techniques and to concurrent satellite data. The MagnaProbe was easy to use and produced transects of virgin snow depth across the sites quickly to give an indication of how the snow depth varied. The data were naturally scattered as snow is a highly variable material. Snow depth and snow-surface type are given in Figure 19 for Michigan and in Figure 20 for Montana. Appendix C includes graphs of the temperature and density profiles (and liquid moisture, if any) for each of the sites.

Figure 19. Snow depth and type by site in Michigan.

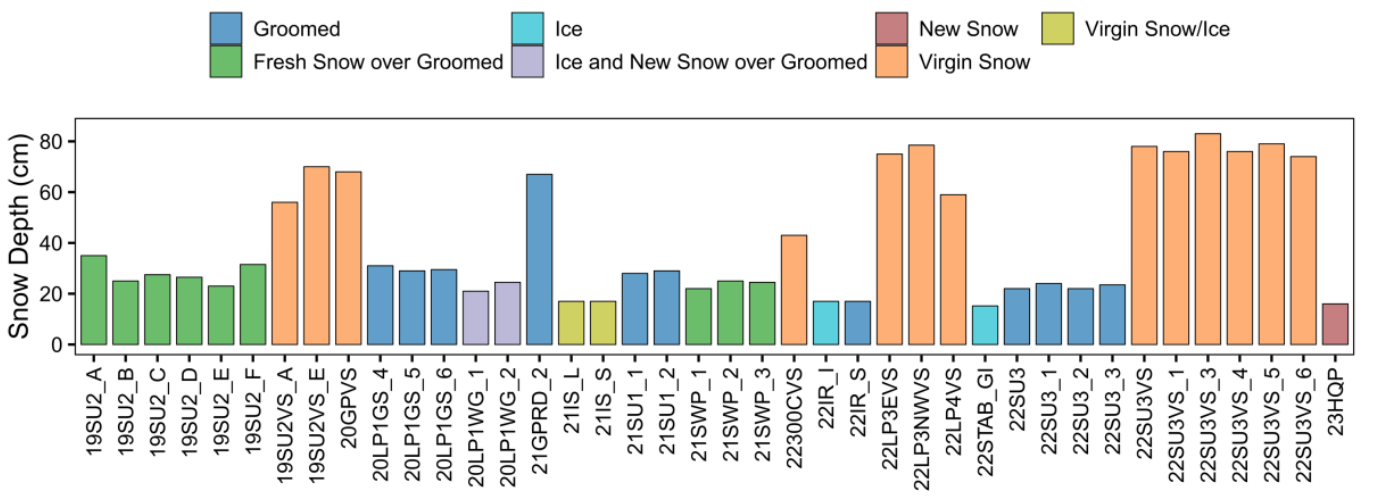

Figure 20. Snow depth by site in Montana.

Fresh Snow over Groomed $\square$ Virgin Snow

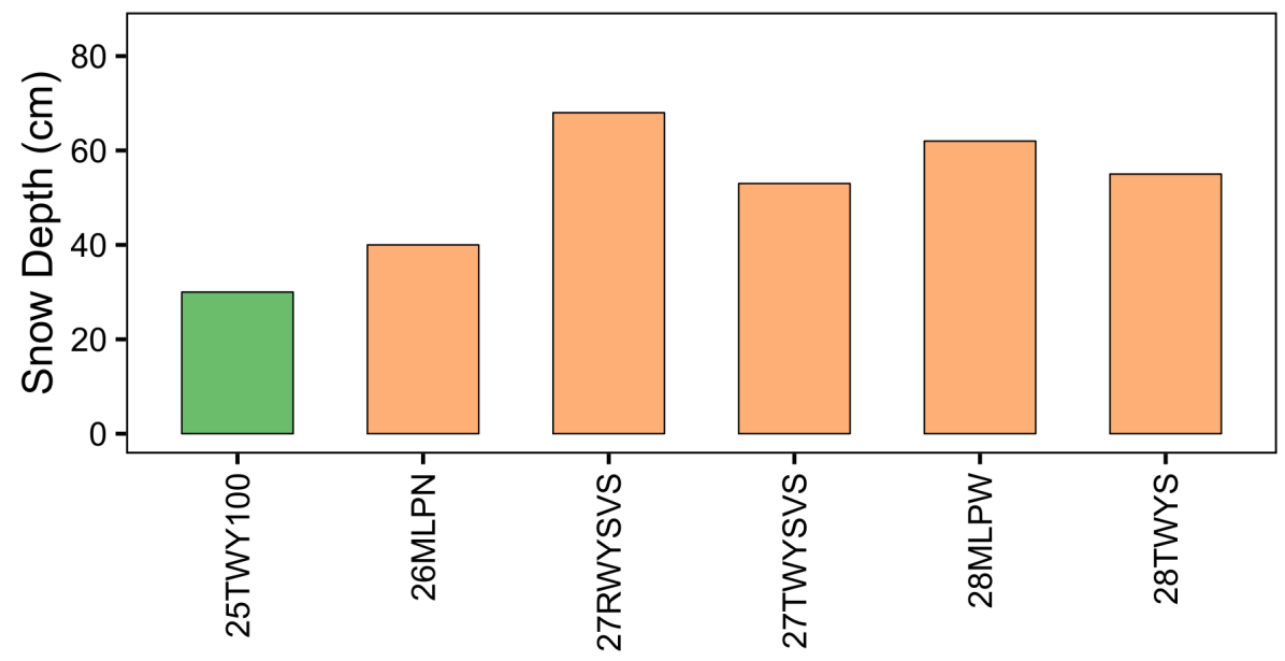


Snow moisture and density were measured in side-by-side measurements by using the Finnish fork, the Denoth meter, and densities from samples collected in numerous snow pits in both Montana and Michigan. We also performed a laboratory experiment for side-by-side measurements of several Denoth meters with the Finnish fork and sample measurements. Figure 21 shows a sample of the comparison of the density and moisture measurements for a variety of snow pits in both Montana and Michigan.

Figure 21. Finnish fork density and moisture compared to sample density and Denoth moisture in different snow pits.

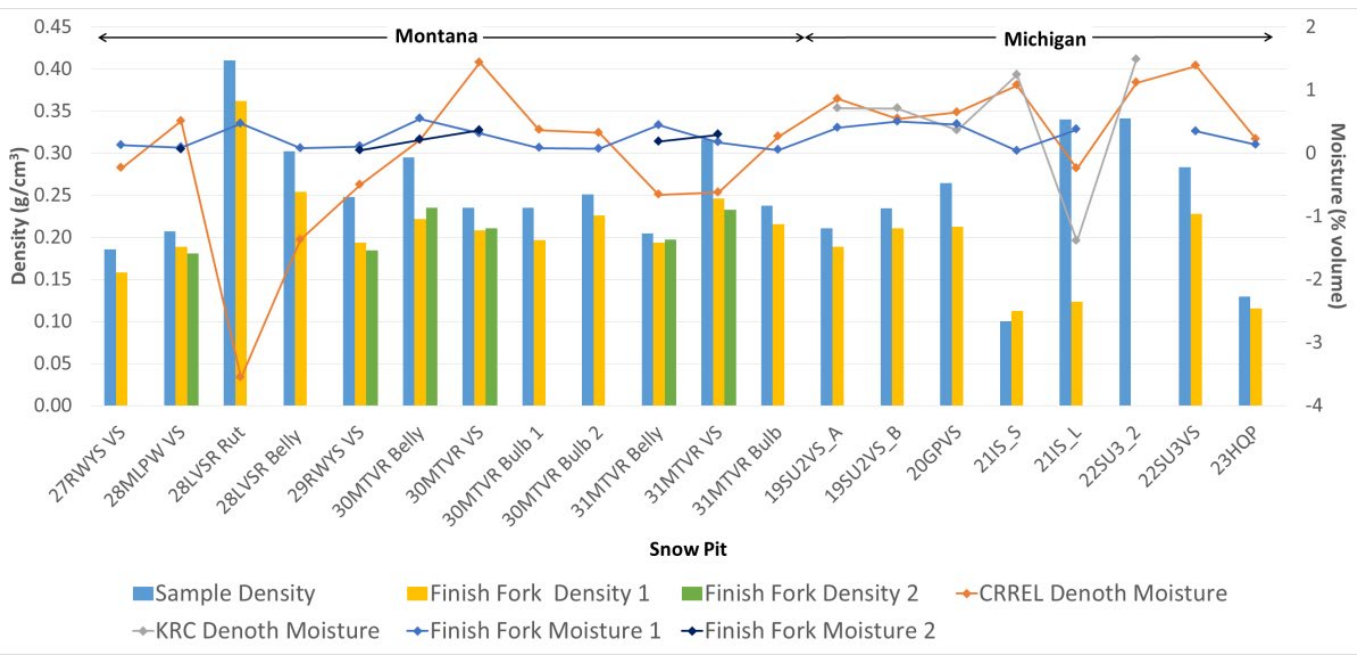

In general, we found good consistency between the snow moisture (liquid water content) measured with the Finish fork and the Denoth meters and consistency between different Denoth meters. We also found that the density measured with the Finish fork tended to be lower than density from collected samples but was unreliable when the snow was wet. Feyrer et al. (2018) completed a preliminary analysis of the full field data set and associated laboratory experiments, reported in the poster in Appendix E. Elder et al. (2019) presents a more thorough analysis.

Figure 22 illustrates NIR photos of a snow pit wall. These photos demonstrate the ability of NIR photography to show different layers within the snow. NIR is sensitive to snow grain size and can be used to estimate snow's specific surface area and to document stratigraphy. 
Figure 22. NIR photo (top) and standard photo (bottom) of Montana snow pits walls.
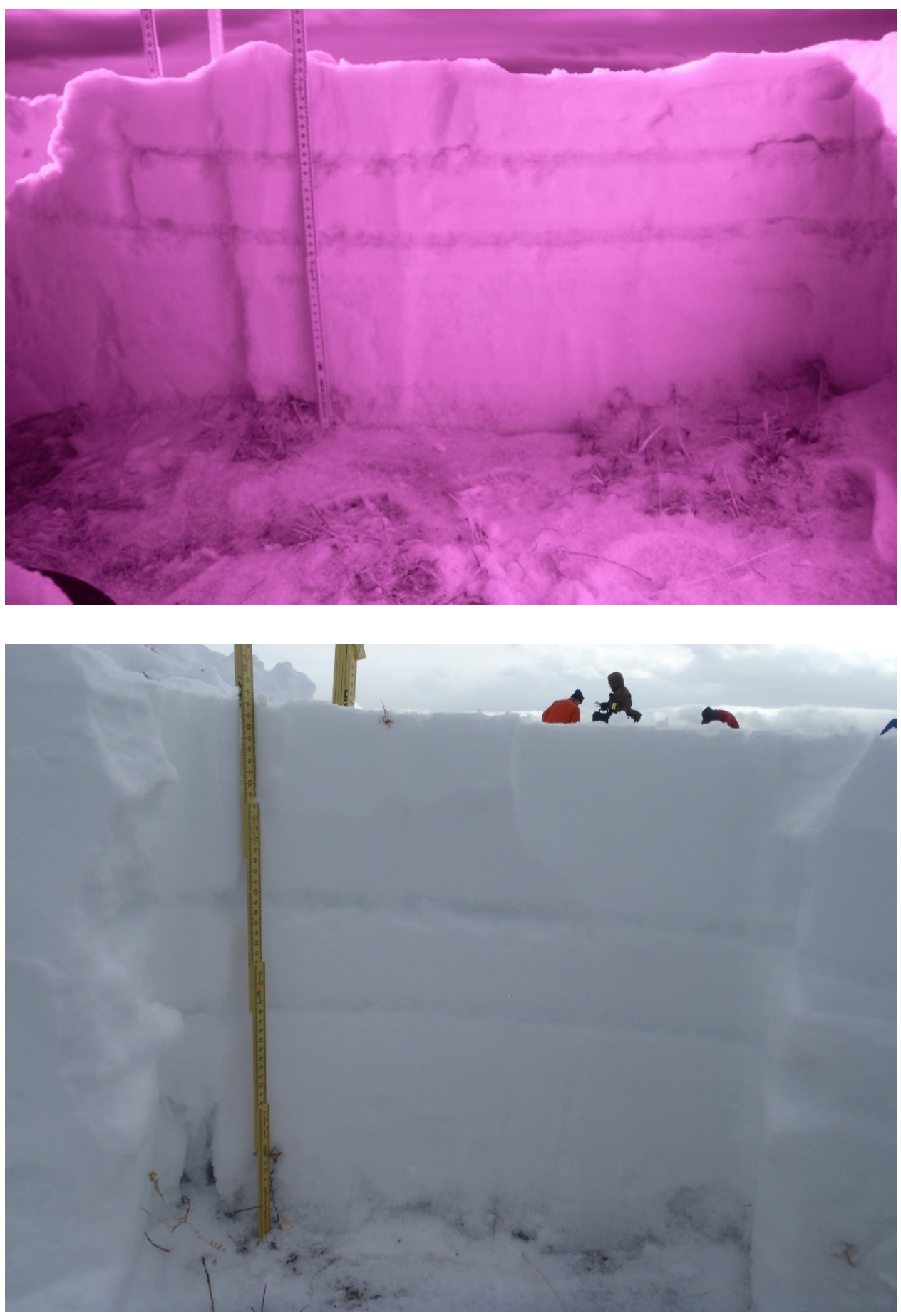

\subsection{Snow-strength measurement techniques}

Many types of strength measurements were used at each site. Some were better suited for soft snow and others for groomed snow, so not all techniques were used at each site. In addition, some are profile measurements that characterize the snow strength with depth. These are not necessarily 
well suited for reducing to a single number as the benefit of the information is to capture the details of the entire snow profile. Figure 23 and Figure 24 compile the strength measurements for the sites at Michigan and Montana, respectively. These plots illustrate the variability at each site and how the strength may be further explored by snow-surface type, as shown in Figure 25 and Figure 26.

Where measurements were collected from multiple surface covers, some differences in strength emerged. In Michigan, there were significant strength differences detected $(p<0.05)$ between surface covers when using the $2.25 \mathrm{~kg}$ Clegg, CTI, ISM load levels 2 and 4, and Rammsonde (ram) (Figure 25). In Montana, only the $0.5 \mathrm{~kg}$ Clegg could distinguish significant strength differences between the surface types (Figure 25). Statistical power was largely limited by the low sample size between surface cover types. Increasing the sample size using strength measurements that function well across different surface types would likely reveal more robust strength relationships.

This type of information, along with further analysis of the data collected in this study, will allow us to optimize the data collections to better suit the snow cover and to tune the strength collection equipment for use in snow (see also Shoop et al. 2019a).

It was apparent that the strength measurement techniques could be grouped based on their suitability to certain snow types.

Table 6 provides an initial assessment of the effectiveness of each of the techniques for use on different types of snow and ice covers. In some cases, a particular instrument was neither good nor bad but completely unsuited to a particular snow type. For example, the RSP usually dropped through virgin snow without a single reading until it hit the underlying ground surface. Other instruments would specifically benefit from modifications for use in snow: plate sinkage, which requires sturdier construction and less complicated wiring, and shear vanes, which would benefit from modified vane sizes tailored to varied snow surfaces. 
Figure 23. Boxplots of each snow-strength measurement technique by study area for the Michigan site.
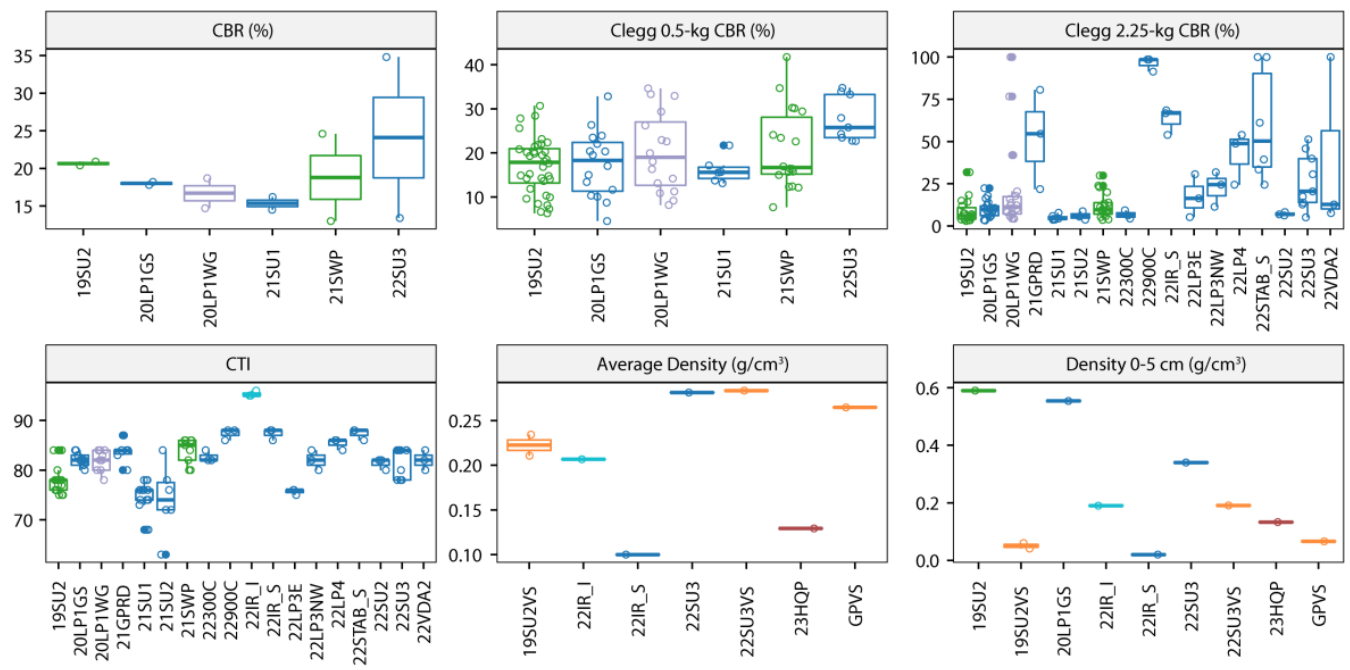

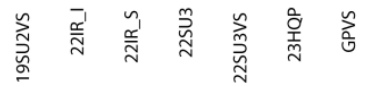
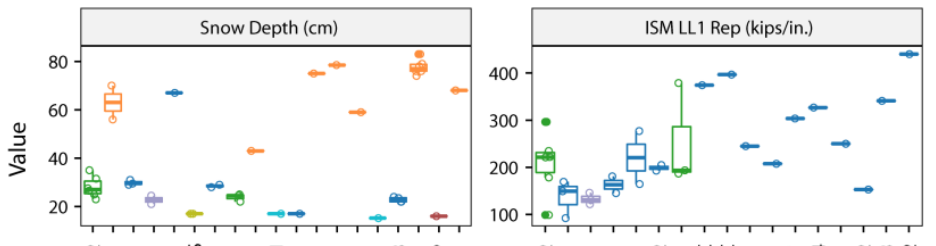

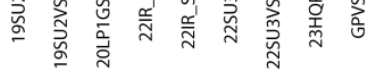
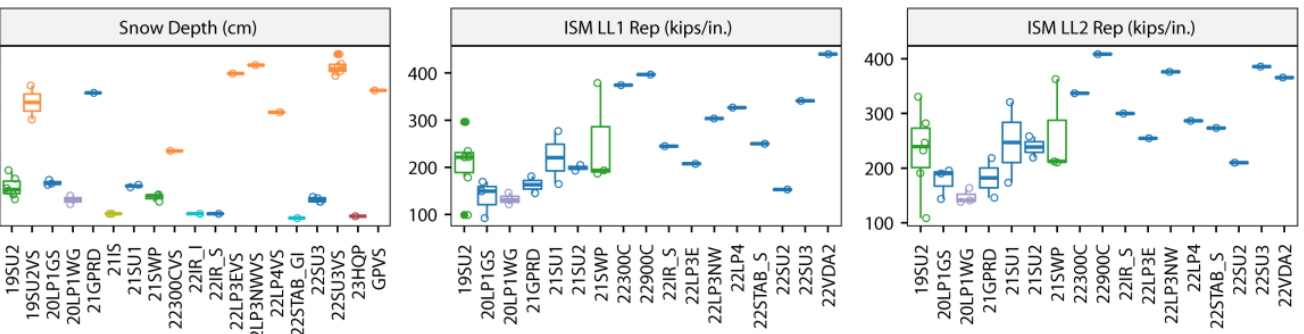

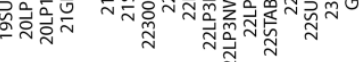
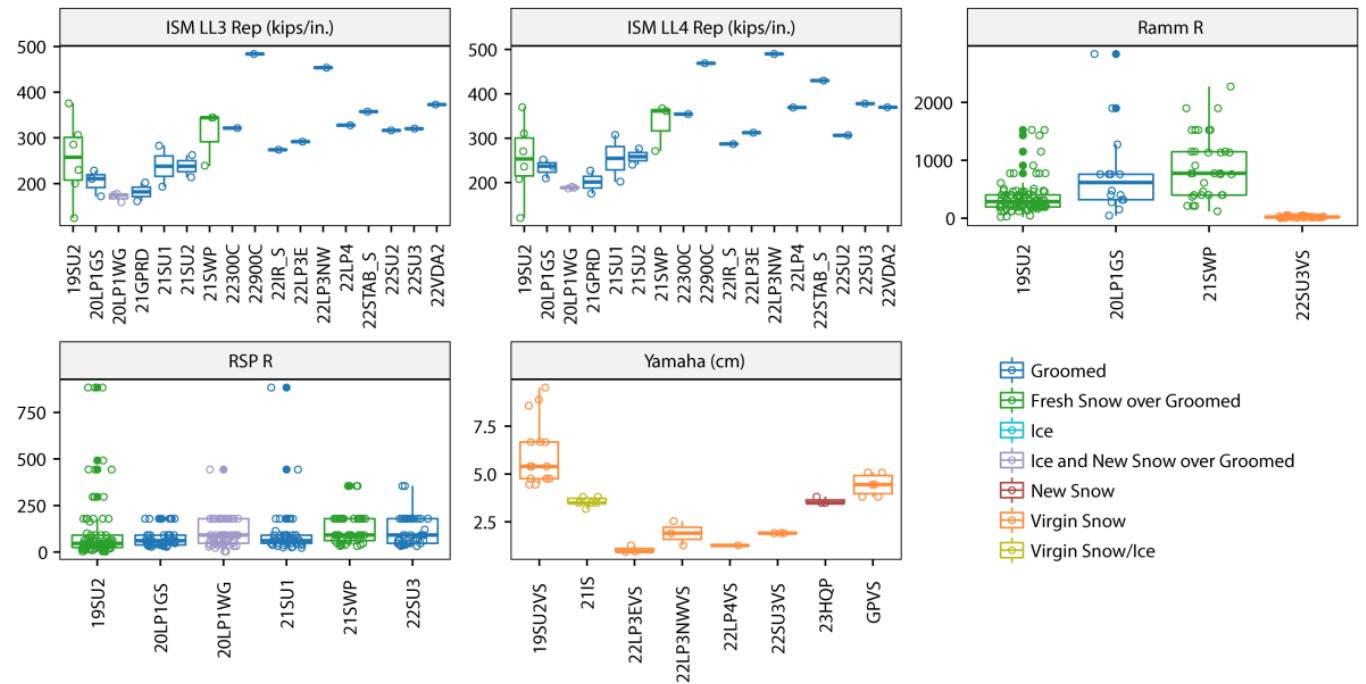

审 Groomed

Fresh Snow over Groomed

부이 Ice

Ice and New Snow over Groomed

审 New Snow

9 Virgin Snow

审 Virgin Snow/lce 
Figure 24. Boxplots of each snow-strength measurement technique by study area at the Montana site.

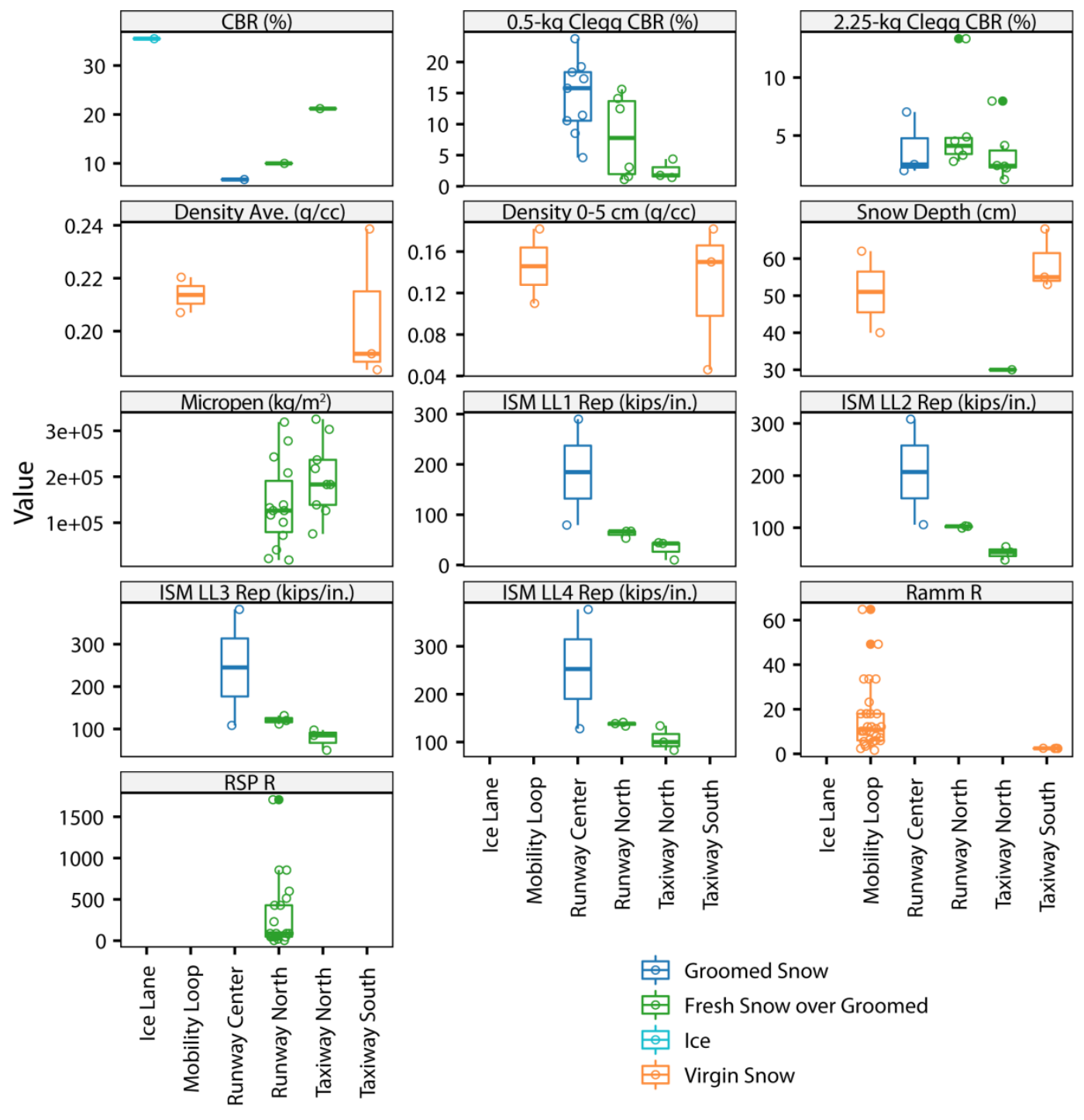


Figure 25. Boxplots of each snow-strength measurement technique by surface type in Michigan. The $p$-values are for Kruskal-Wallis analysis of variance.
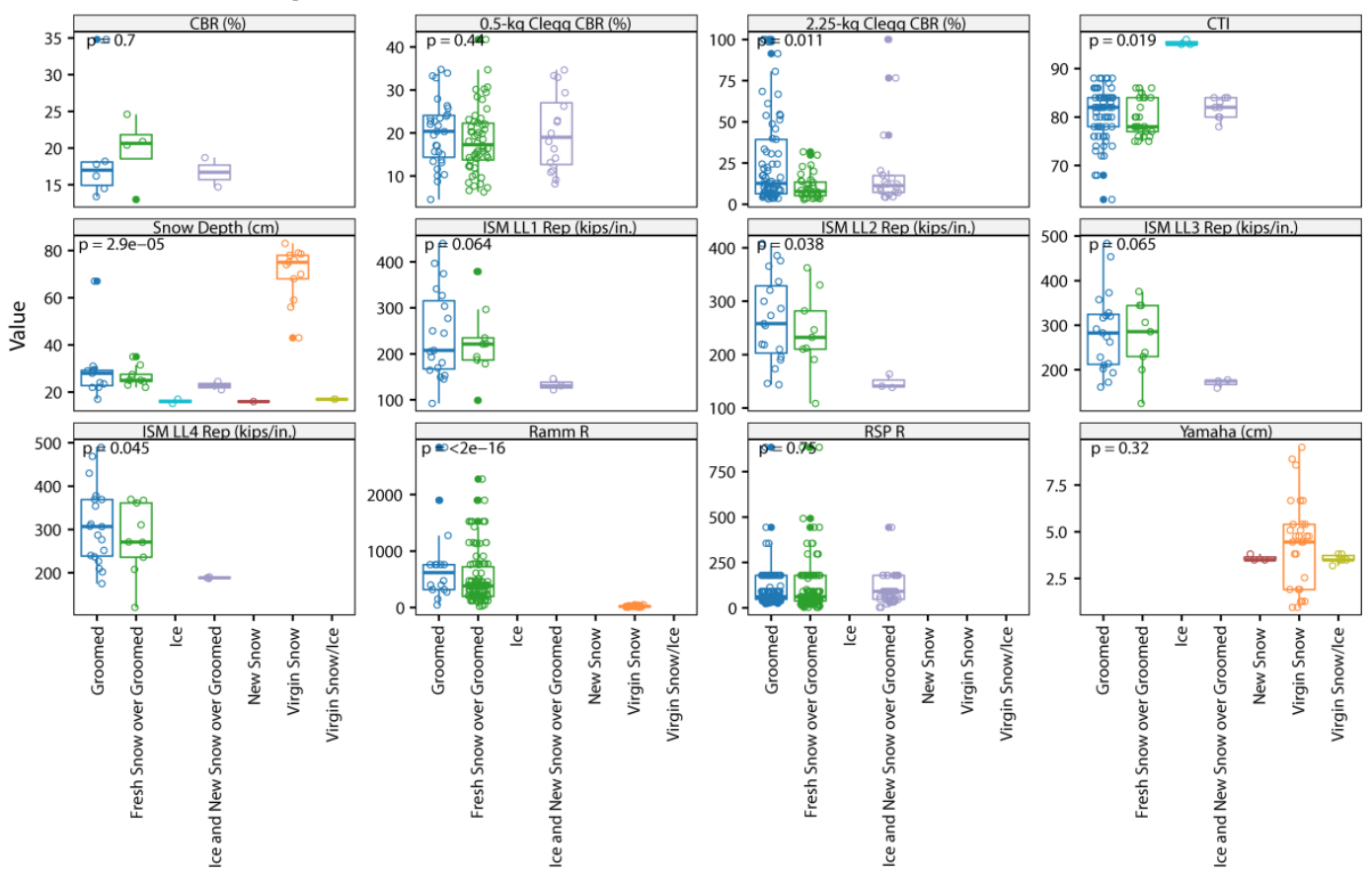

Figure 26. Boxplots of each snow-strength measurement technique by surface type for Montana. The $p$-values are for Kruskal-Wallis analysis of variance.
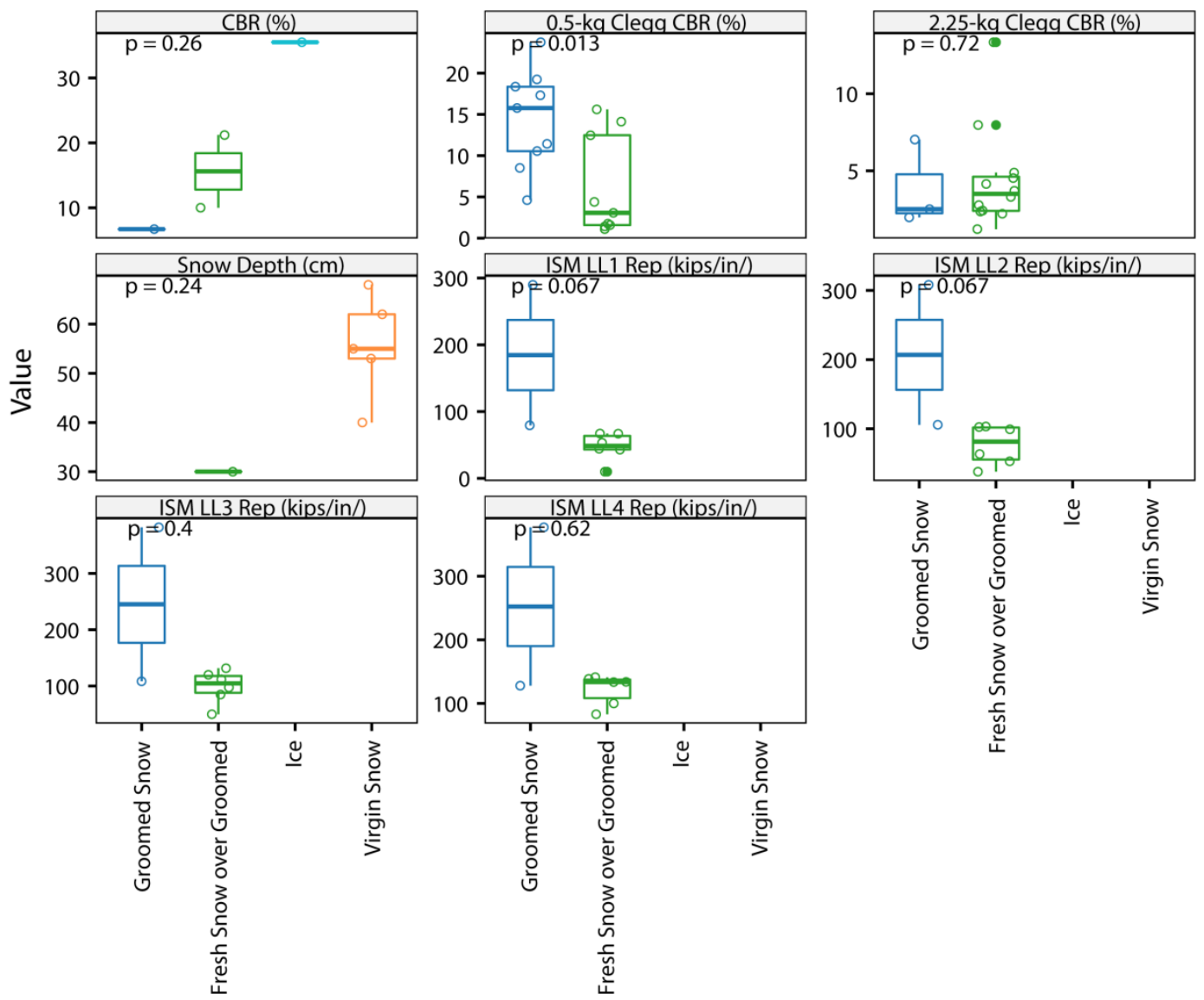
Table 6. Effectiveness matrix of field tests as rated by operators $(1=$ good, $5=$ bad).

\begin{tabular}{|c|c|c|c|c|c|c|c|}
\hline \multirow{2}{*}{\multicolumn{2}{|c|}{ Instrument }} & \multicolumn{6}{|c|}{ Snow-Surface Condition } \\
\hline & & $\begin{array}{l}\text { Hard Groomed } \\
\text { Snow }\end{array}$ & $\begin{array}{c}\text { Medium } \\
\text { Groomed Snow }\end{array}$ & $\begin{array}{c}\text { Fresh snow } \\
\text { Over Groomed }\end{array}$ & Virgin Snow & Wind Crust & Ice Layers \\
\hline \multirow[t]{3}{*}{ Penetrometers } & SMP & unsuitable & 5 & 1 & 1 & 1 & 1 \\
\hline & Ram & 3 & 2 & 3 or 4 & 3 or 4 & not used & unsuitable \\
\hline & RSP & 1 & 1 & not used & unsuitable & not used & not used \\
\hline \multirow[t]{6}{*}{ Bearing Capacity } & Field CBR & 1 & 2 & unsuitable & unsuitable & not used & 1 \\
\hline & LWD & 4 & 4 & 1 & unsuitable & not used & 2 \\
\hline & $2.25 \mathrm{~kg}$ Clegg & 2 & 3 & 5 & unsuitable & not used & unsuitable \\
\hline & $0.5 \mathrm{~kg}$ Clegg & 2 & 2 & 2 & 1 to 5 & not used & unsuitable \\
\hline & Plate Sinkage 6 in. ${ }^{*}$ & not used & not used & not used & 2 & not used & not used \\
\hline & Plate Sinakge 12 in. & not used & not used & not used & 5 & not used & not used \\
\hline \multirow[t]{5}{*}{ MicroTools } & Snow Plate Penetrometer & 5 & 5 & 3 & 5 & 1 & 5 \\
\hline & Pocket Penetrometer & 3 & 2 & 5 & 5 & 2 & 1 \\
\hline & Shear Vane & 3 & 2 & 5 & 5 & 5 & 5 \\
\hline & Yamaha Drop Cone & 5 & 3 & 2 & 1 & 3 & 4 \\
\hline & CTI & 1 & 1 & 5 & 5 & not used & not used \\
\hline
\end{tabular}

* Prototype unit with additional 5, 7, 9, 10, and 11 in. diameter plates. 


\subsubsection{Snow-strength profile data}

Several of the snow measurements collect data within the snow cover as a function of depth. The most basic of these are the snow density, moisture content, and stratigraphy. We also collected snow strength with depth using the ram, the RSP, and the SMP. Each of these instruments was designed for a specific application. The ram CRREL used in this study was designed with a smaller tip for use on snow roads and airfields in Antarctica and Greenland. The RSP was designed by the Russians for groomed snow runways. The SMP was designed to operate in light alpine snowpacks and to be sensitive to structural weaknesses within the snowpack for assessing avalanche hazards (Schneebeli and Johnson 1998). Figure 27 and Figure 28 provide examples of the data from the RSP in Michigan and the SMP in Montana. Much of the profile data were averaged into layers for future analysis.

Figure 27. RSP hardness profiles from Michigan.

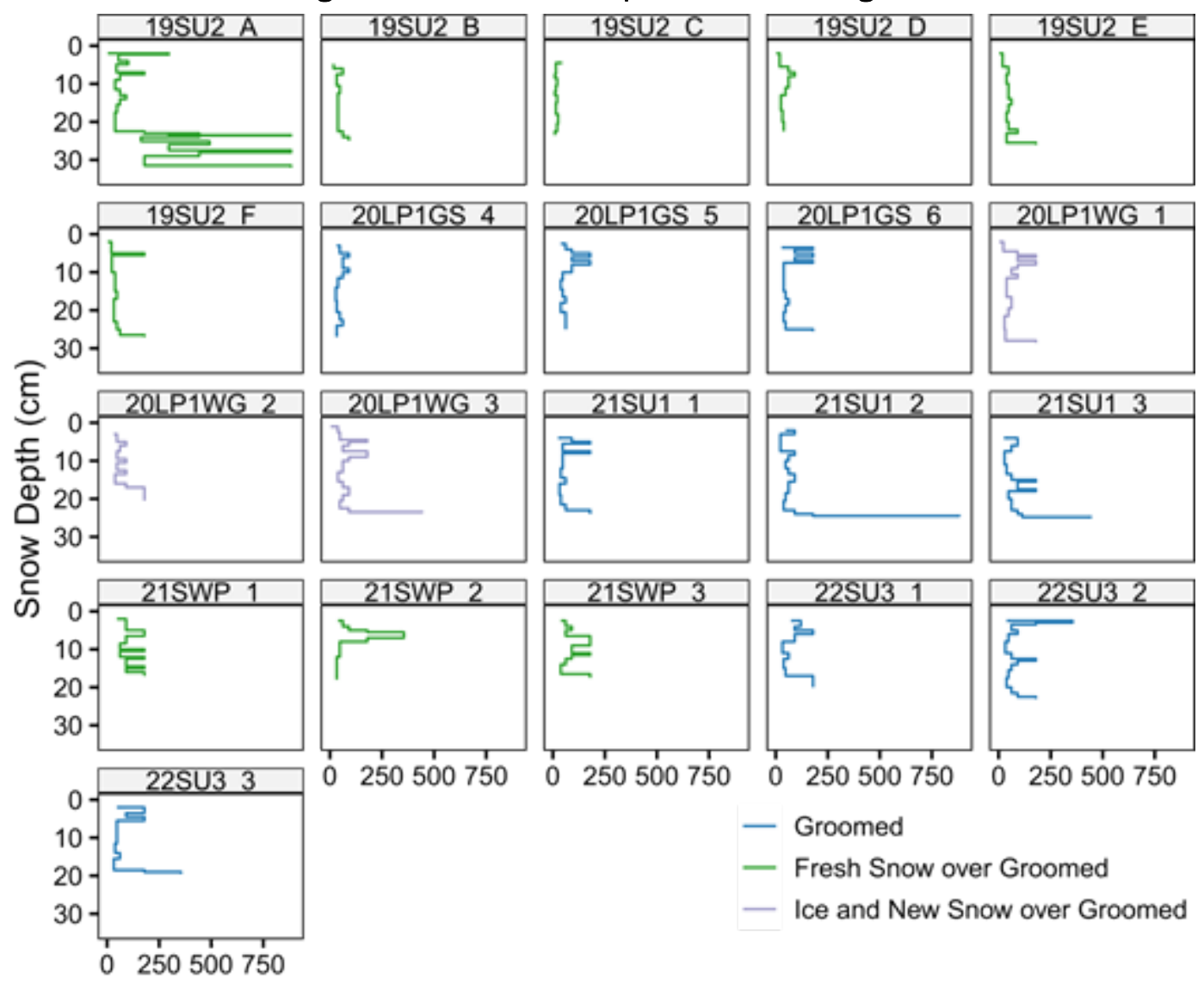

Russian Snow Penetrometer $R$ 
Figure 28. SMP profile from virgin snow in Montana.

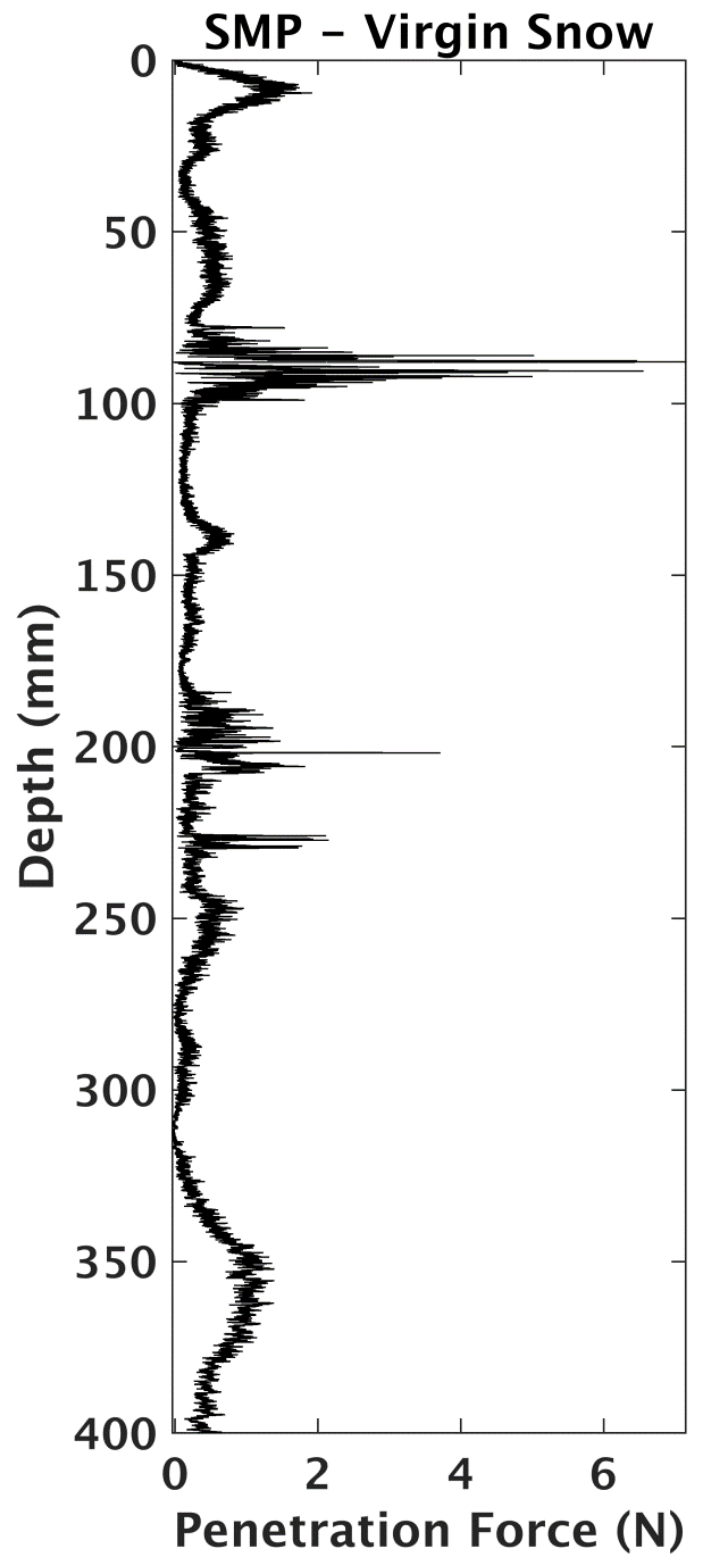

\subsubsection{Strength of groomed snow surfaces}

Field CBR measurements are used to compare in situ strength to design parameters for roads and airfields. While this methodology is being replaced by mechanical design methods, CBR methods are still in use within the Department of Defense. Published data for true field-measured CBR for snow and ice surfaces are practically nonexistent; therefore, we performed these field CBR tests in both Michigan and Montana. Figure 29 and Figure 30 summarize the CBR measurements colored by surface type. 
Figure 29. Measured CBR by site in Michigan.

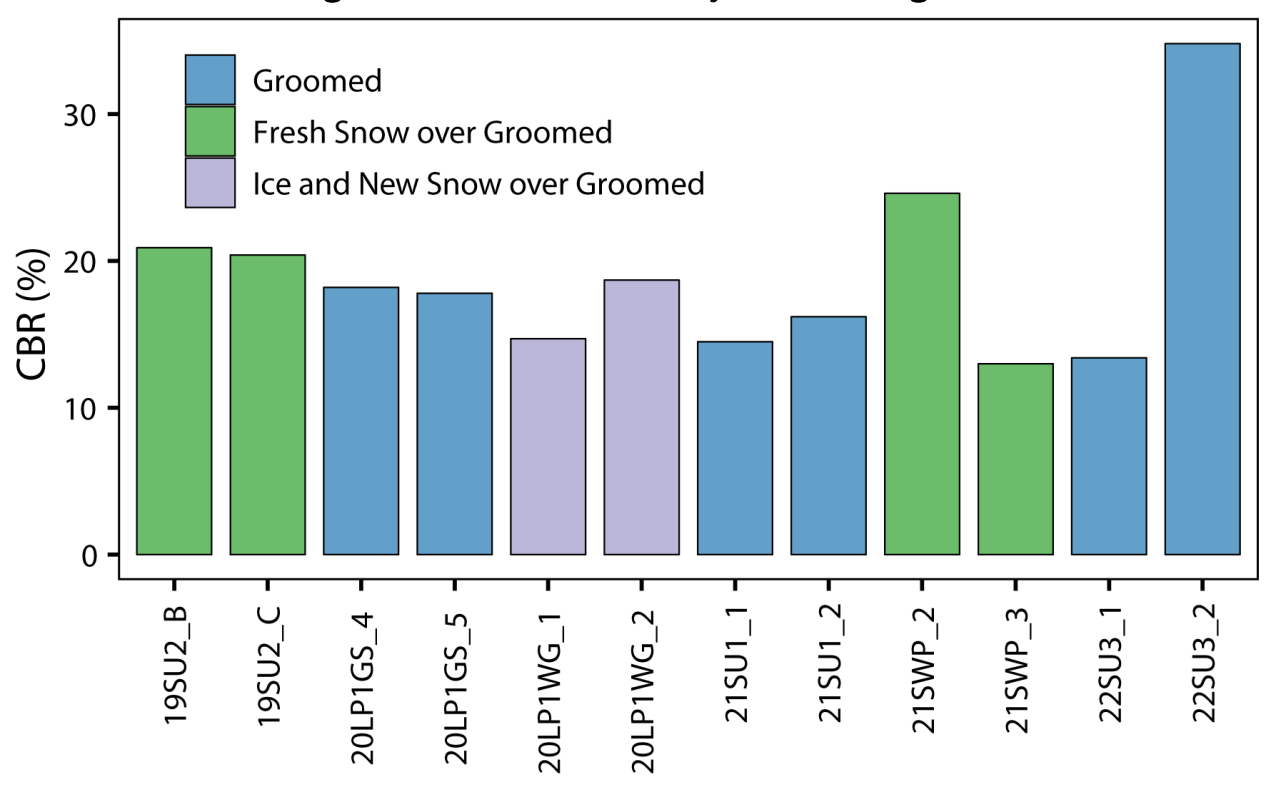

Figure 30. Measured CBR by site in Montana.

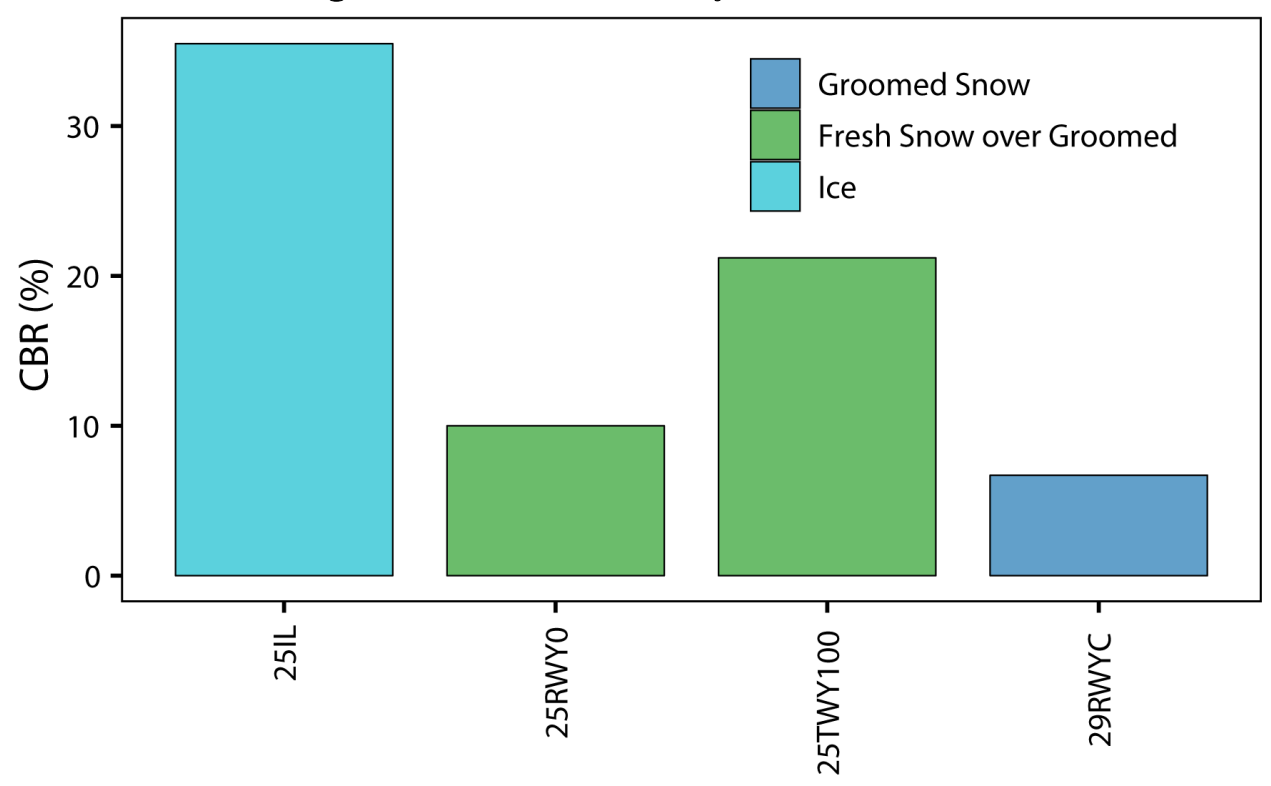

The two Cleggs proved efficient for assessing snow surfaces, being both easy to operate and quick. While the $0.5 \mathrm{~kg}(1.1 \mathrm{lb})$ Clegg was useful for many of the virgin and packed snows, the $2.25 \mathrm{~kg}(5 \mathrm{lb})$ Clegg was the most useful for a wide range of packed-snow surfaces (but not ice, which was out of the instrument range). Figure 31 and Figure 32 give the overall results for $2.25 \mathrm{~kg}$ Clegg measurements converted to CBR, showing the average and standard deviation by site, colored by surface type. 
Figure 31. Mean site surface CBR calculated from $2.25 \mathrm{~kg}$ Clegg Impact Values in Michigan. Error bars are \pm one standard deviation.

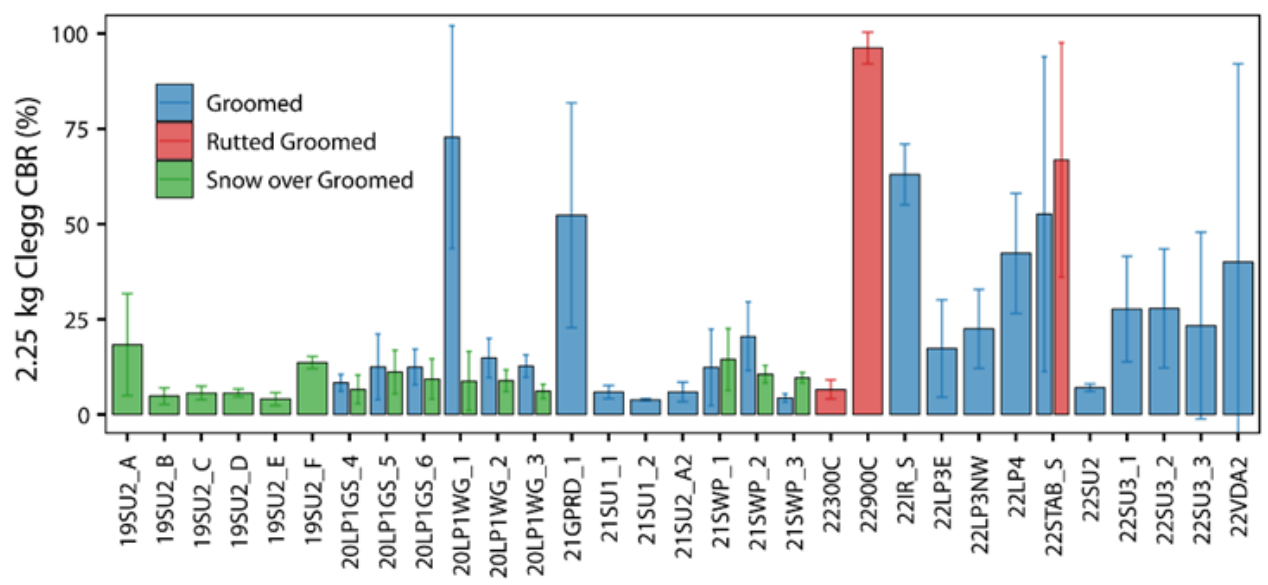

Figure 32. Mean site surface CBR calculated from $2.25 \mathrm{~kg}$ Clegg Impact Values in Montana. Error bars are \pm one standard deviation.

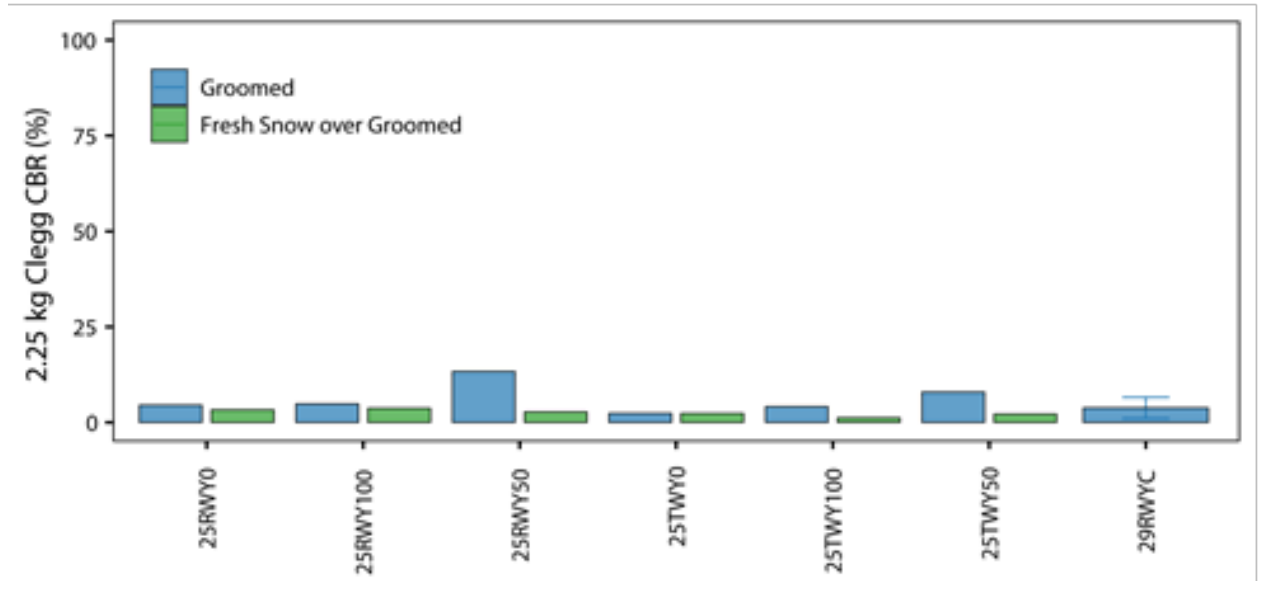

The LWD was also used on groomed snow but left large indentations on many of the groomed snow surfaces, indicating that it was continuing to compact the snow under the impact of the test sequence. Wieder et al. (2019) analyzes the LWD more thoroughly.

Photos of the underlying ground conditions, shown in Appendix B, raise an important concern for groomed surfaces and may explain some of the outlier measurements for the Clegg and CBR measurements from Michigan shown in Figure 29 and Figure 31 (the groomed snow in Montana was generally over paved surfaces). If the ground surface is uneven, from either vegetation or ruts made by vehicles on an aggregate- or soil-surfaced road, then as the snow is groomed, it will most likely vary in depth and density. If test equipment with a small foot print, such as the Clegg, is placed over a high point on the underlying ground surface, we could feasibly measure a 
higher value due to the influence of the nearby frozen ground, and yet the groomed snow surface is visually uniform.

Additionally, some test points in Michigan, were close to trees and other vegetation that cast shadows during parts of the day. The difference in snow strength due to difference in temperature and sun exposure could impact snow strength.

In further investigations of measures of snow strength, the corresponding depth, temperature, and density of the snow layer being tested need to be more thoroughly quantified, especially for the groomed snow surfaces. For bearing tests (i.e., CBR, Clegg, and LWD), the measurement depth, or depth of influence, varies depending on the surface contact area of the device. Knowing that the impact of the test may be deeper than the snow layer, thus penetrating into the ground surface below, would be of benefit. For the LWD, the backcalculation program requires the thickness, an initial estimate of modulus, and Poisson's ratio for each layer. Modulus and Poisson's ratio of snow both vary significantly with snow density. Wieder et al. (2019) discuss this further as it impacted the results of the LWD test the most. In Montana, the technique to measure density in the high-density groomed snow was not available, and the underlying surface was usually paved.

\subsubsection{Correlation between strength measurements}

We also evaluated the strength measurements to determine which correlated with each other, as shown in the correlation matrix in Figure 33. Higher rho values are shown as darker colors and indicate a stronger correlation. The matrix indicates the following:

- Good correlations, $p<0.01$, between the LWD ISM values at all four load levels. Further discussion of the implications of this is included in Wieder et al. (2019).

- Good correlations, $p<0.01$, between CTI and the other surface measurements-both Cleggs and the RSP and ram averages that include the shallow readings $(0-15 \mathrm{~cm}$ and full depth).

- Fair to good correlations, $p$ varies from $<0.1$ to $<0.01$, between the near-surface RSP, near-surface ram, and both Cleggs. 
Figure 33. Spearman correlation matrix of measured snow properties with $n>1$ comparative observations. LWD ISM values listed are representative (averages are nearly identical). The $p$ values are indicated as $*<0.1, * *<0.05$, and $* * *<0.01$.

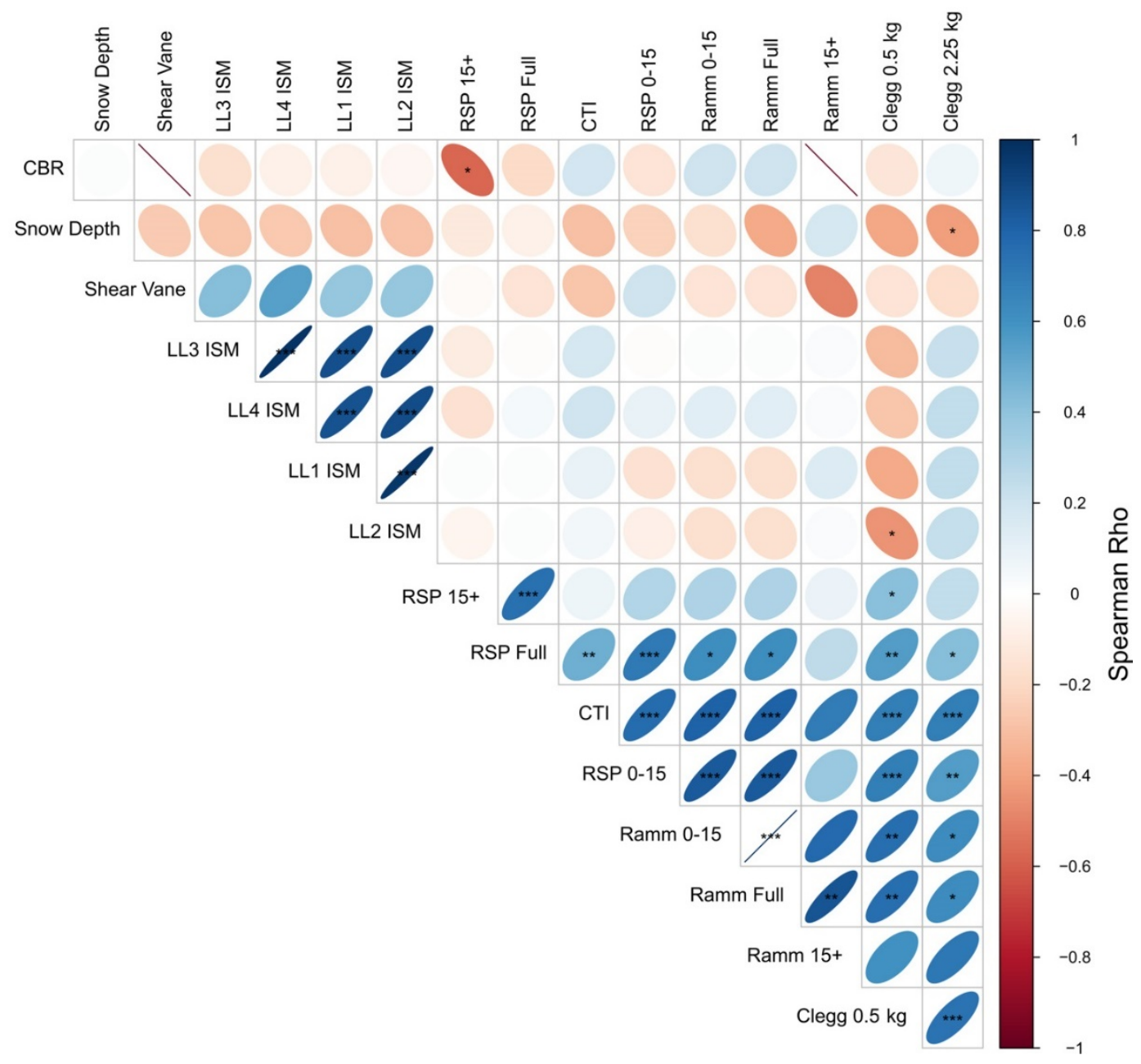

Bearing-strength measurements were also correlated to calibrate strength measurements to the traditional field-measured CBR. While many of these correlations are poor, a few show expected trends, such as the Clegg's CIV (Figure 34).

There were a couple other correlations of note:

- A positive trend exists between the CTI snow compaction gauge and the $0.5 \mathrm{~kg}$ Clegg CIV (Figure 35). Both are tools that are very light and engage only near-surface snow.

- The RSP and the 2.25 kg Clegg CIV trend similarly, both of which are tools for stronger surfaces (the RSP is used for groomed snow airfields), Figure 36. 
Figure 34. CIV versus field CBR.

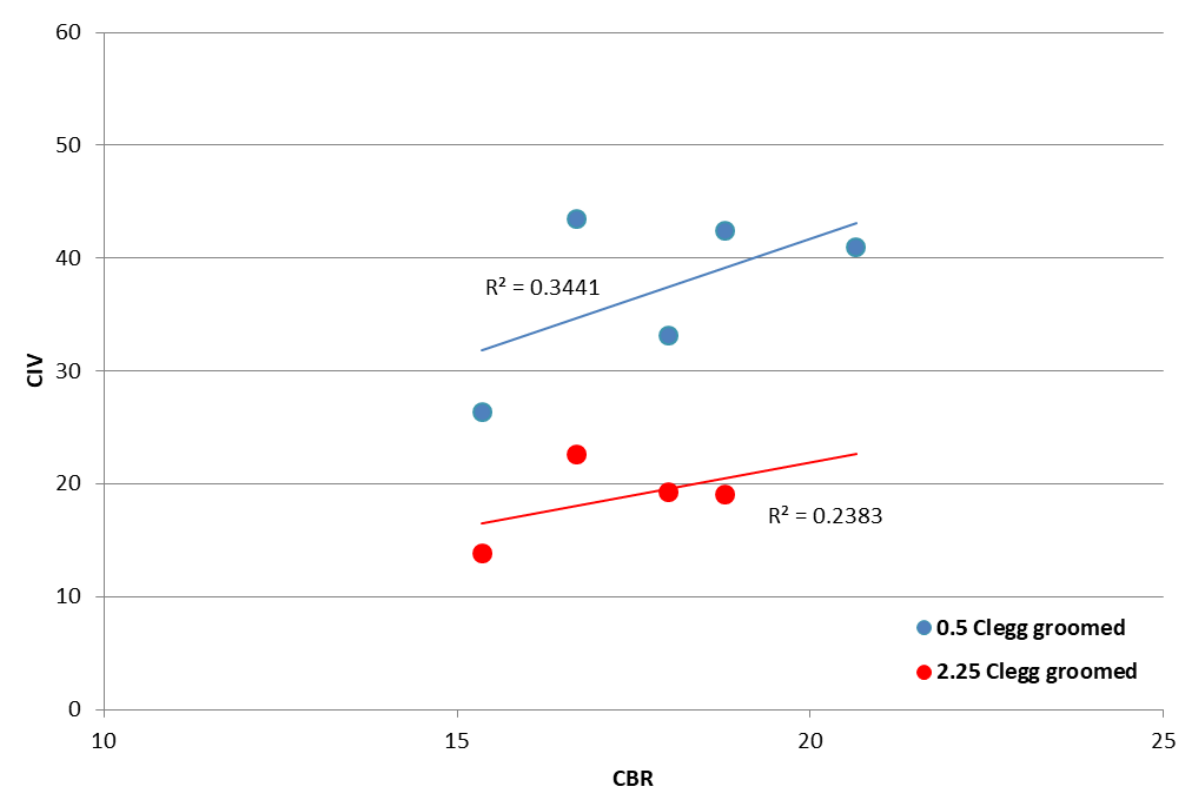

Figure 35. CTI versus $0.5 \mathrm{~kg}$ Clegg CIV.

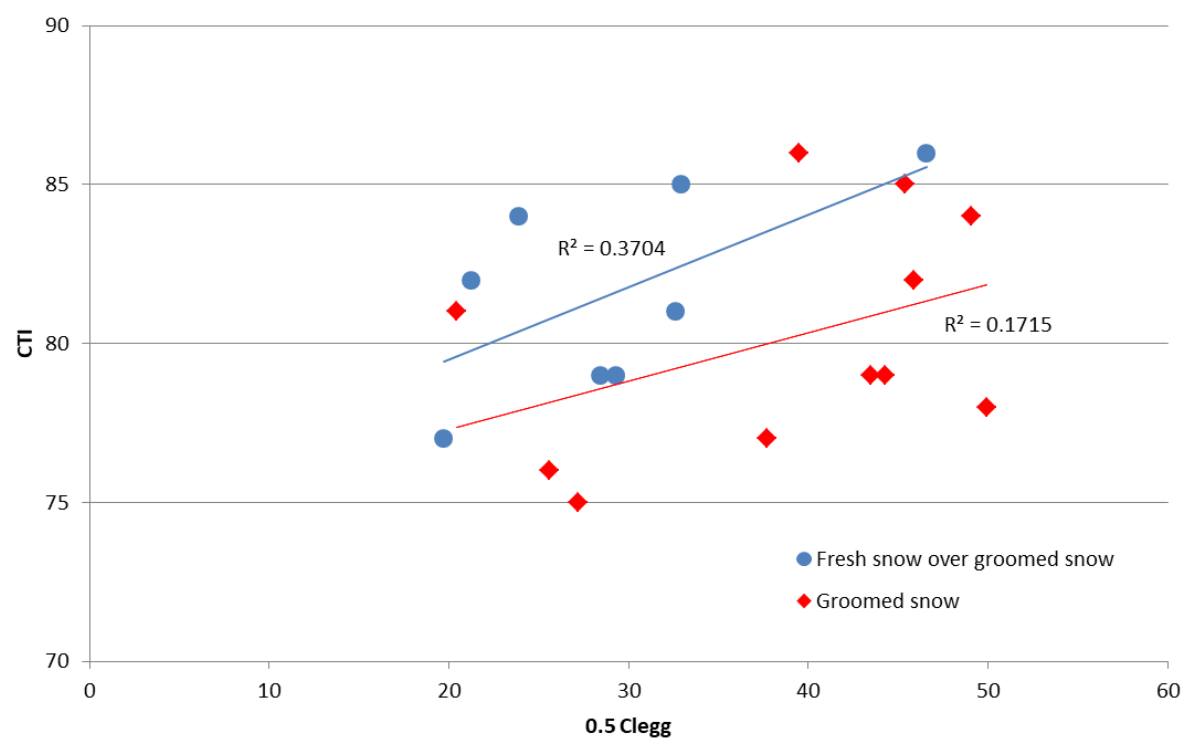


Figure 36. RSP versus $2.25 \mathrm{~kg}$ Clegg CIV.

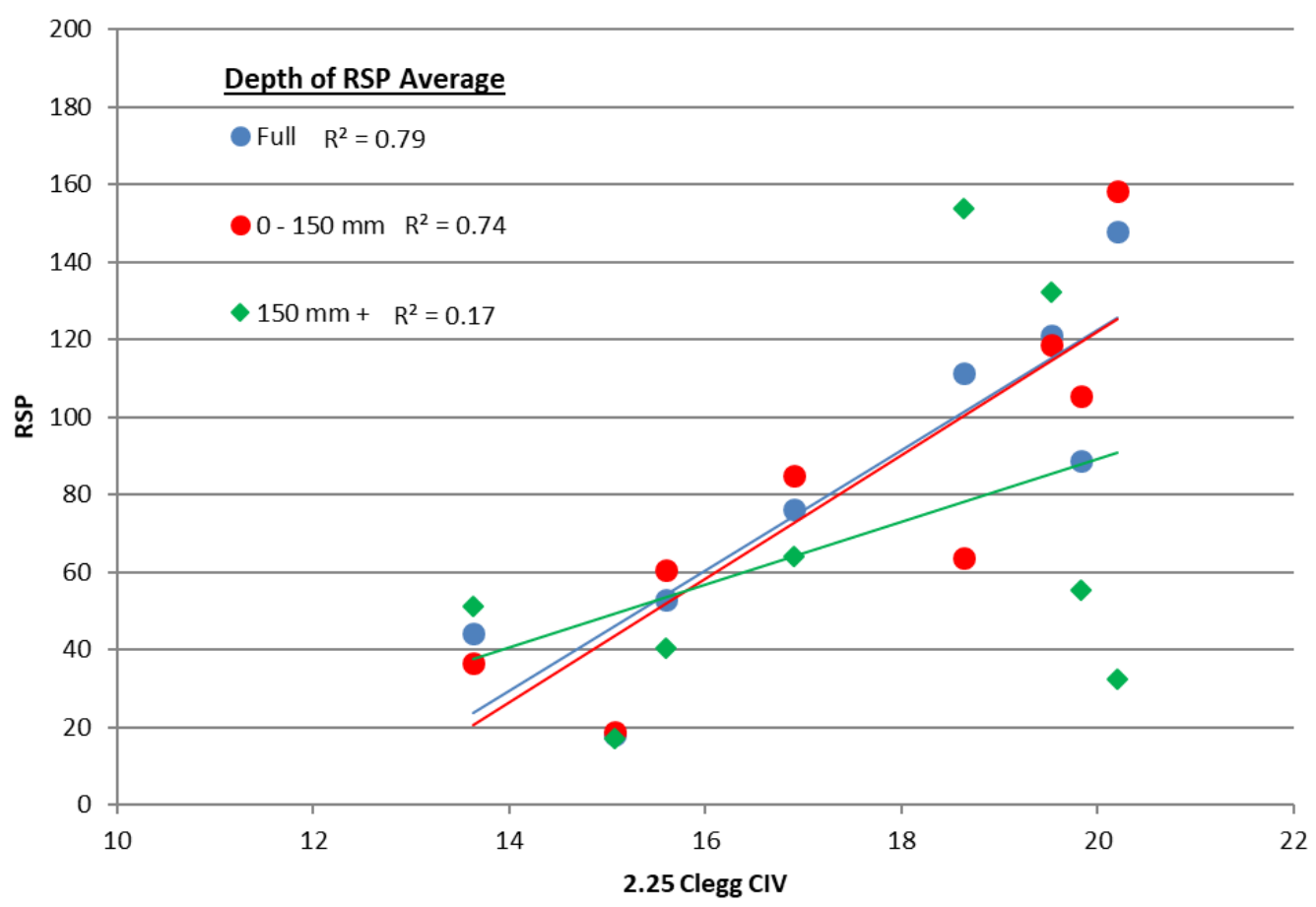

\subsection{Spectral measurements}

\subsubsection{WV2 and WV3 satellite imagery}

One of the key objectives of the field campaigns was to explore the relationship between snow mechanical properties and remotely sensed data by using concurrent imagery collected by the $\mathrm{WV} 2$ and $\mathrm{WV} 3$ satellites. The WV satellite images from Montana were excessively cloudy, but the Michigan images were clear and were further analyzed based on snow-surface type and also compared to strength. The WV2 and WV3 satellites use optical sensors operating in the visible through infrared portion of the electromagnetic spectrum. The sensors measure reflected solar energy from snow or ground surfaces and not from any buried stratigraphic layers.

The spectra for the 9 pixels surrounding each measurement site $(5.5 \times 5.5$ $\mathrm{m}[18 \times 18 \mathrm{ft}]$ on the ground) were collected from the image and assembled in Figure 37. The data in Figure 37 are from WV3 imagery taken on 26 February 2018. The test-point surfaces are described as they were found on the day of the ground testing at each test point, 19-22 February 2018. The colors represent the different types of surfaces: 
- Clear pavement-in this case asphalt concrete

- Groomed snow-snow that, either over a road, pavement, or open area, had been groomed by plows or other equipment

- Fresh snow over groomed snow-a surface that had received new snowfall over a previously groomed snow layer

- Ice-ice surfaces specifically prepared for vehicle testing

- Ice with new snow cover over groomed snow-testing specific to a day with freezing rain and snow, which overlaid the previously groomed snow surface

- New snow-an area previously cleared with only recent snowfall accumulation

- Virgin snowpack-snow that had not been disturbed by vehicle traffic, the accumulation of season's snowfall

These spectra were further averaged by snow type and displayed to show characteristic WV3 spectra for each surface type in Figure 38. Appendix F provides additional data from the satellite imaging.

For most of the spectra, we noticed a dip in the values at $550 \mathrm{~nm}$ (green band) that should not be there. This is especially prominent in Figure 38 but can also be seen in Figure 37. The reason for this is not clear, and it has not been reported elsewhere. It could be either due to an error in atmospheric correction processing or to the original data from the satellite. This same dip is not observed in the on-site ASD measurements taken 22 February 2018. The $\mathrm{WV}_{3}$ imagery was reprocessed with atmospheric corrections and different algorithms to recalculate the reflectance but again resulted in the same issue with the $550 \mathrm{~nm}$ wavelength. Potentially, the problem could be linked to issues with the satellite sensor. These are both being further explored. 
Figure 37. WV2/WV3 reflectance spectra for each Michigan study area. Each line represents a site. The colors relate to the type of surface.

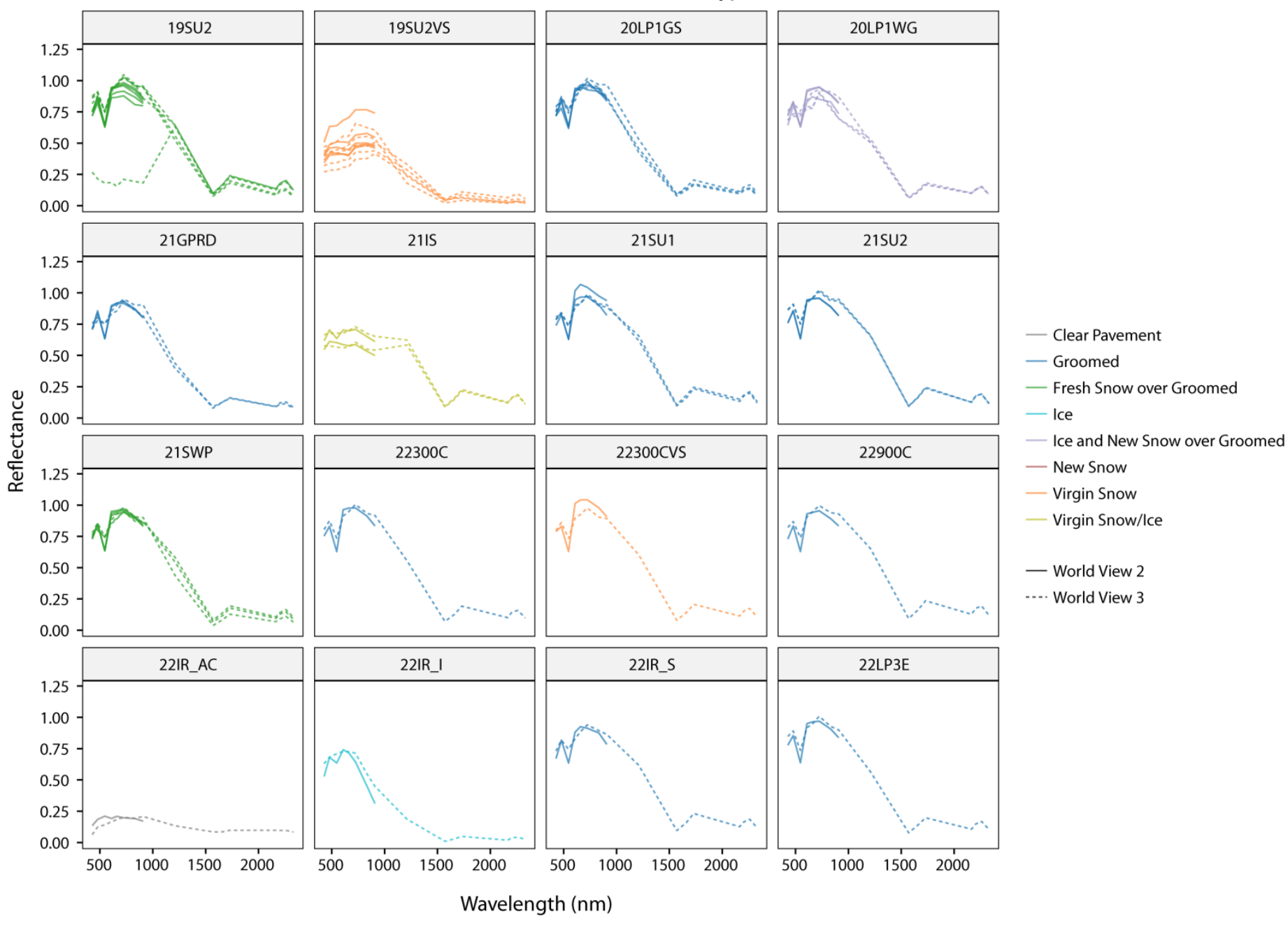


Figure 37 (cont.). WV2/WV3 reflectance spectra for each Michigan study area. Each line represents a site. The colors relate to the type of surface.

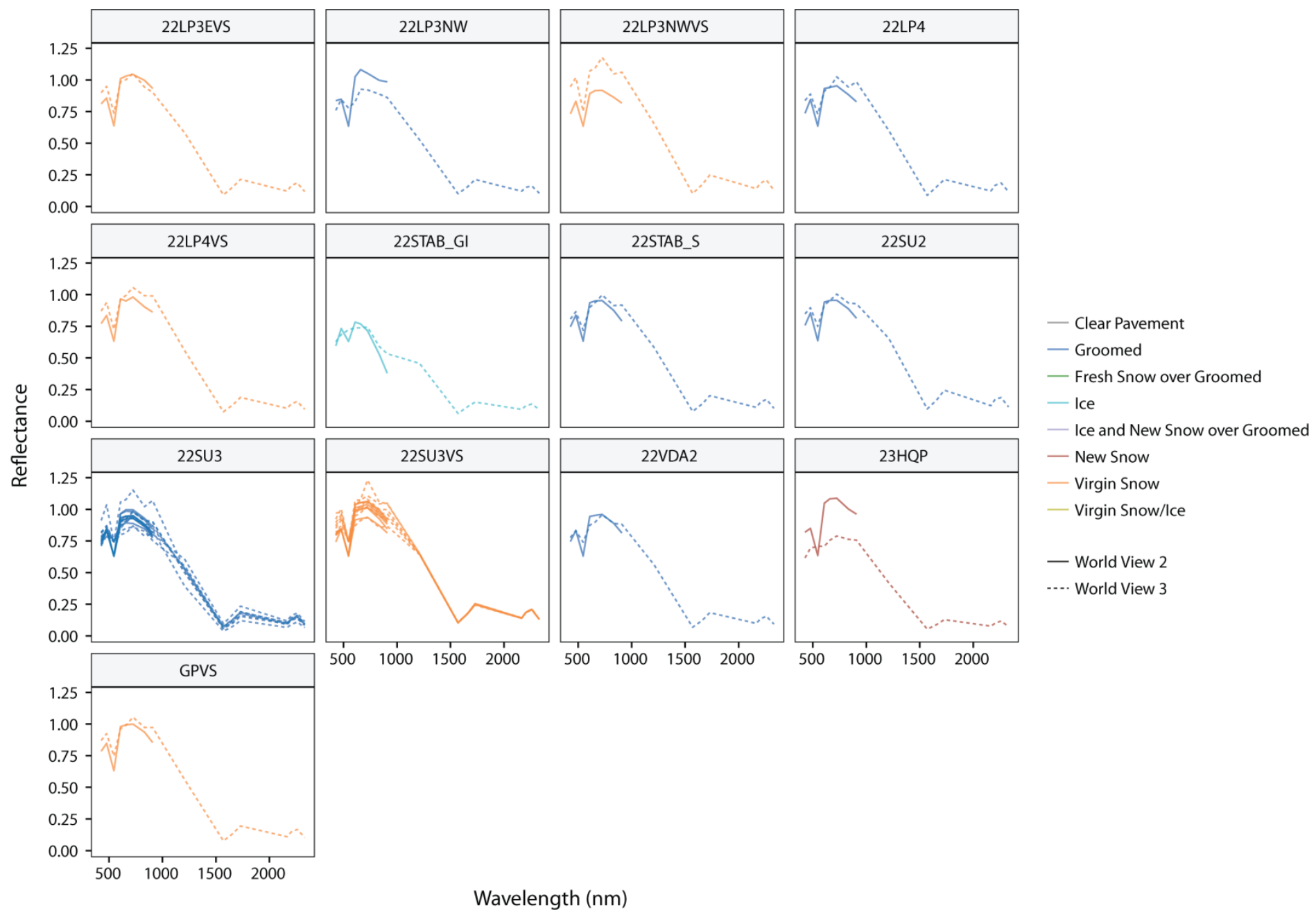


Figure 38. Michigan WorldView reflectance spectra averaged by surface type.

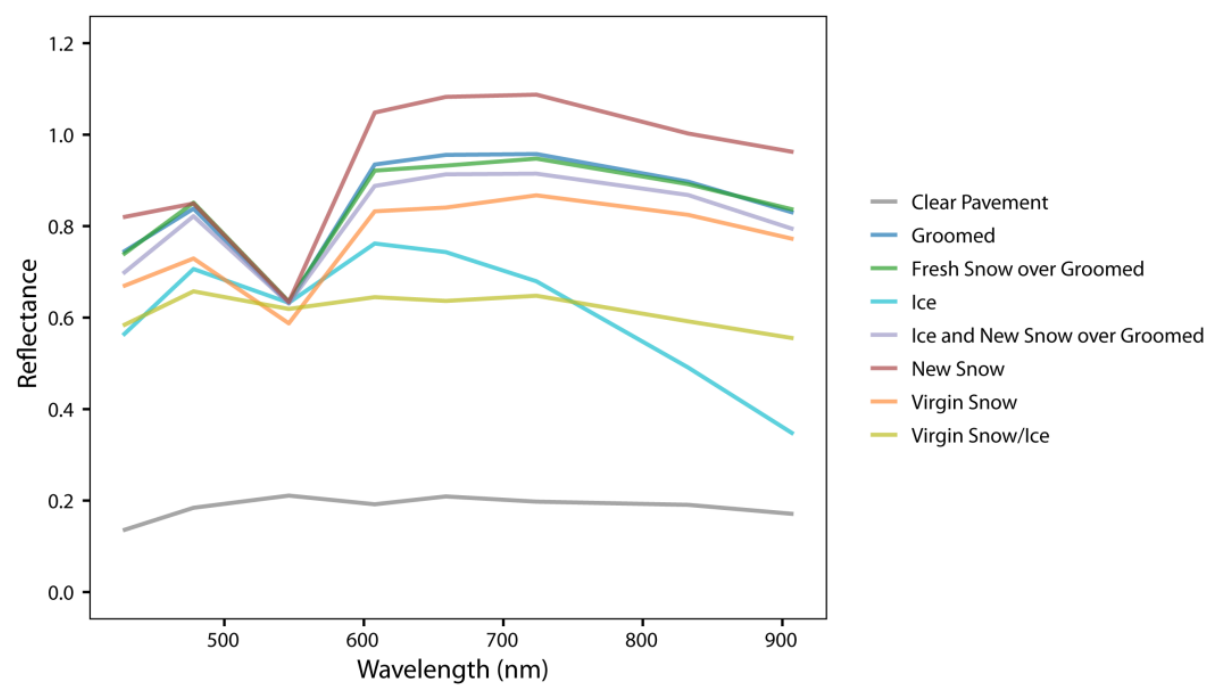

\subsubsection{Satellite TSX imagery}

Despite the high spatial resolution of the TSX radar backscatter (X-band $\sim 1 \mathrm{~cm}$ wavelength, $10 \mathrm{GHz}$ frequency) allowing for general discrimination of tracked and untracked surfaces, the data appear limited by the integrated backscatter from surface roughness and volume (e.g., within snowpack) scattering. Further work will explore the benefit of multipolarization radar acquisitions (i.e., horizontal and vertical, as well as co- and cross-polarized products) toward a more quantitative relationship between radar backscatter and snow mechanical properties. The multipolarization mode of the TSX satellite has a spatial resolution limitation but may be able to separate surface versus volume scattering. Our 2019 TSX collections test this approach with larger prepared surfaces.

\subsubsection{ASD field-measured reflectance}

For most locations where snow properties and strength were measured, the nadir spectral reflectance of the surface was also measured using the ASD field spectrometer. Whereas the $\mathrm{WV}_{2}$ and $\mathrm{WV} 3$ data are discretized into bands of wavelengths, the ASD provides a more continuous waveform in $1 \mathrm{~nm}$ increments. The magnitude and spectral shape of the reflectance spectra are known to be related to surface snow grain size and wetness (Nolin et al. 1993; Painter et al. 1998, 2003, 2009); but how these change with surface metamorphosis and surface aging is an area of current research. We analyzed the reflectance spectra in a variety of different ways to determine if the different snow surfaces could be easily distinguished with noncontact 
sensing. For simplification, we can parse these spectra into the same bands by averaging the reflectance within the wavelength intervals or bands of the WV2 and WV3 imagery. Figure 39 is a graph of the eight WV2 bands for all of the ASD measurements taken in Michigan on 22 February 2018, colored by surface type and showing general trends for the major winter surfaces of interest to vehicle mobility. Appendix G provides photo examples of the snow and ice surface conditions tested with the ASD.

Figure 39. ASD field spectrometer reflectance subsampled into the eight WV2 bands for asphalt, groomed snow, ice, and virgin snow surfaces in Michigan.

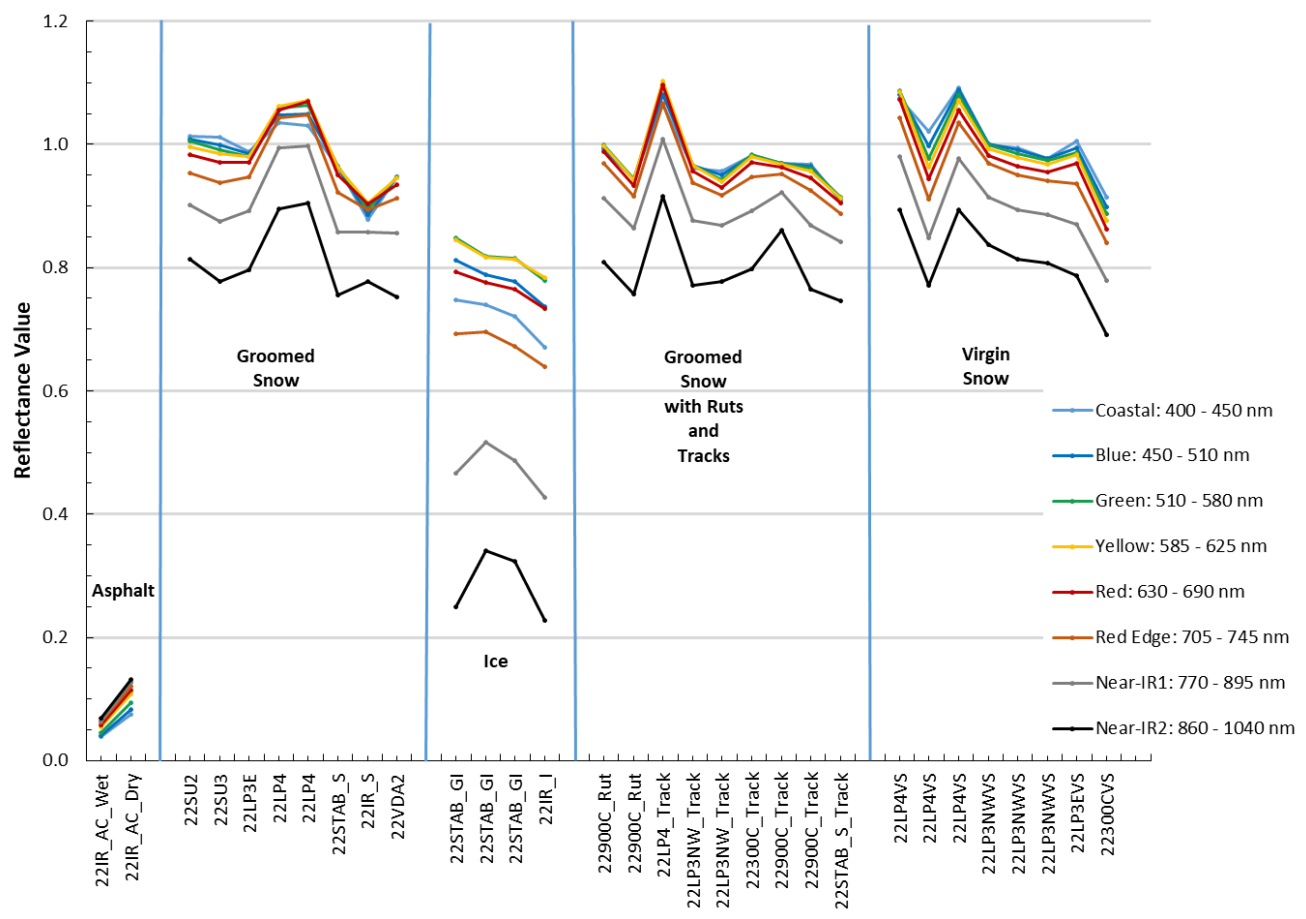

We can further look at the data in terms of the full suite of bands used in the newer WV3 satellite. Figure 40 shows the ASD spectra averaged into WV3 bands for a collection of virgin snow, groomed snow, ice, and asphalt surfaces. The asphalt, snow, and ice are clearly distinguishable, but the different types of snow surfaces are not distinguishable from one another.

Since some of the snow surfaces had been trafficked by vehicles, we also looked at the differences between the tracked and smooth snow surfaces. The tracked snow surfaces showed greater variability in reflectance due to the geometry of the tracks providing a variable nadir reflectance. The resulting variability is greater than that of groomed versus virgin snow. 
Figure 40. Michigan ASD field spectrometer reflectance subsampled into the WV3 bands. Red lines are for asphalt, purple for ice, blue for groomed snow, and green for virgin snow. The panchromatic band is 450 to $800 \mathrm{~nm}$.

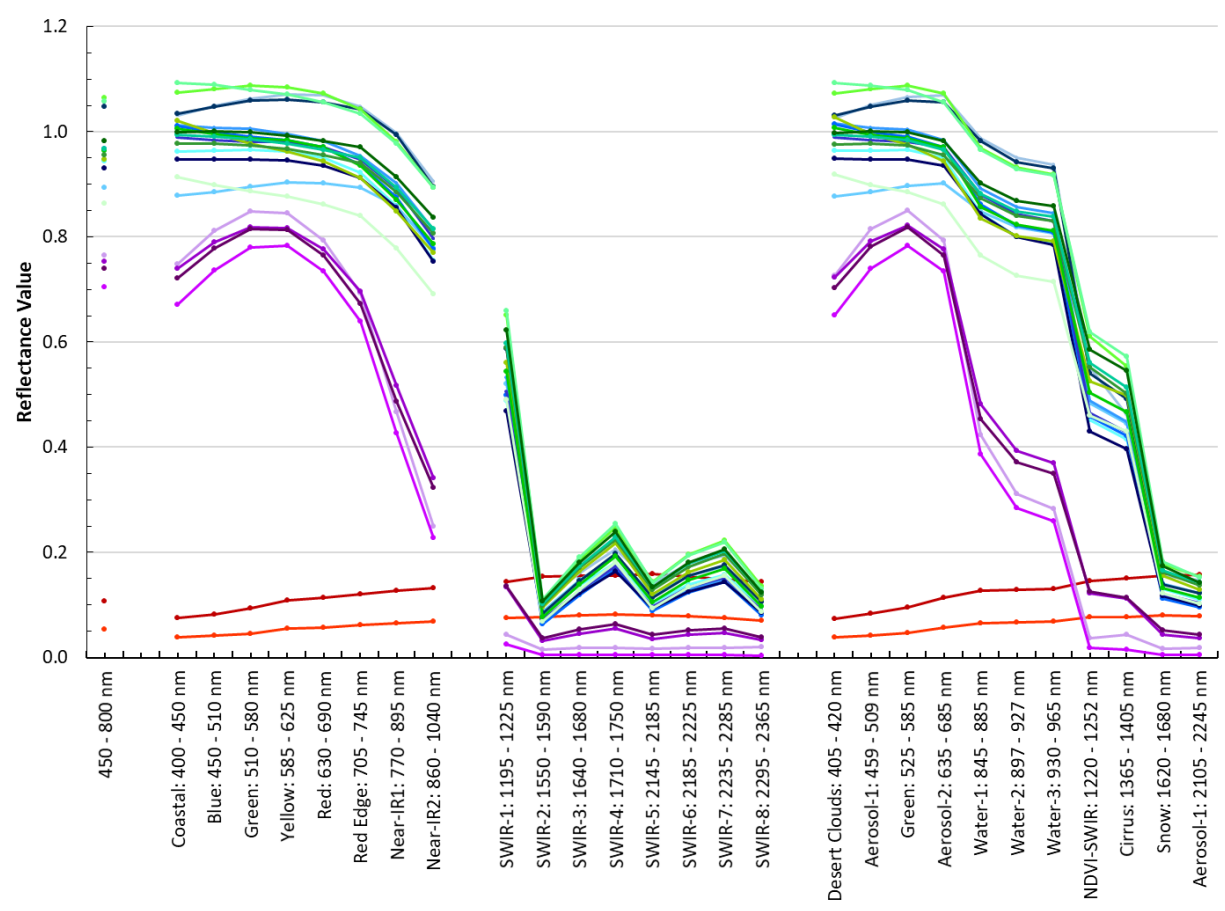

Figure 41 shows the analysis of the full spectral waveforms for all of the virgin snow spectra collected on a single day. All of these were measured within 2 hours of solar noon, and a white reference plate was used to measure incident radiation before and after each measurement and to correct the reflectance spectra. There is considerable scatter in these data from $350 \mathrm{~nm}$ to $1350 \mathrm{~nm}$. The variability in the spectra are more than expected and are likely due to variations in cloud cover, which would impact the magnitude of the incident solar radiance. Over the course of the ASD testing, the cloud cover transitioned from cirrostratus clouds at the beginning of the measurement period to altocumulus clouds at the end of the measurements, as seen in the photos in Appendix G. Clouds can prevent some wavelengths from reaching the surface; therefore, the incident solar radiation signature changes as do the resultant reflectance values. In addition, the spectral shape at small wavelengths is inconsistent between the measurements, and some of the spectra display an upward or downward curve in the small wavelengths that is unlike a characteristic virgin-snow spectral shape (D. Perovich, CRREL, pers. comm., 2019). We will further explore these inconsistencies and fine-tune the collection and processing technique in the future. The spectra scatter at specific wavelengths of 1400,1900 , and $2500 \mathrm{~nm}$ is noise from small amounts of solar energy 
reaching the Earth's surface at those wavelengths due to atmospheric water absorption (Wallace and Hobbs 1977).

Figure 41. Full spectra of the Michigan ASD reflectance from the virgin snow measurements.

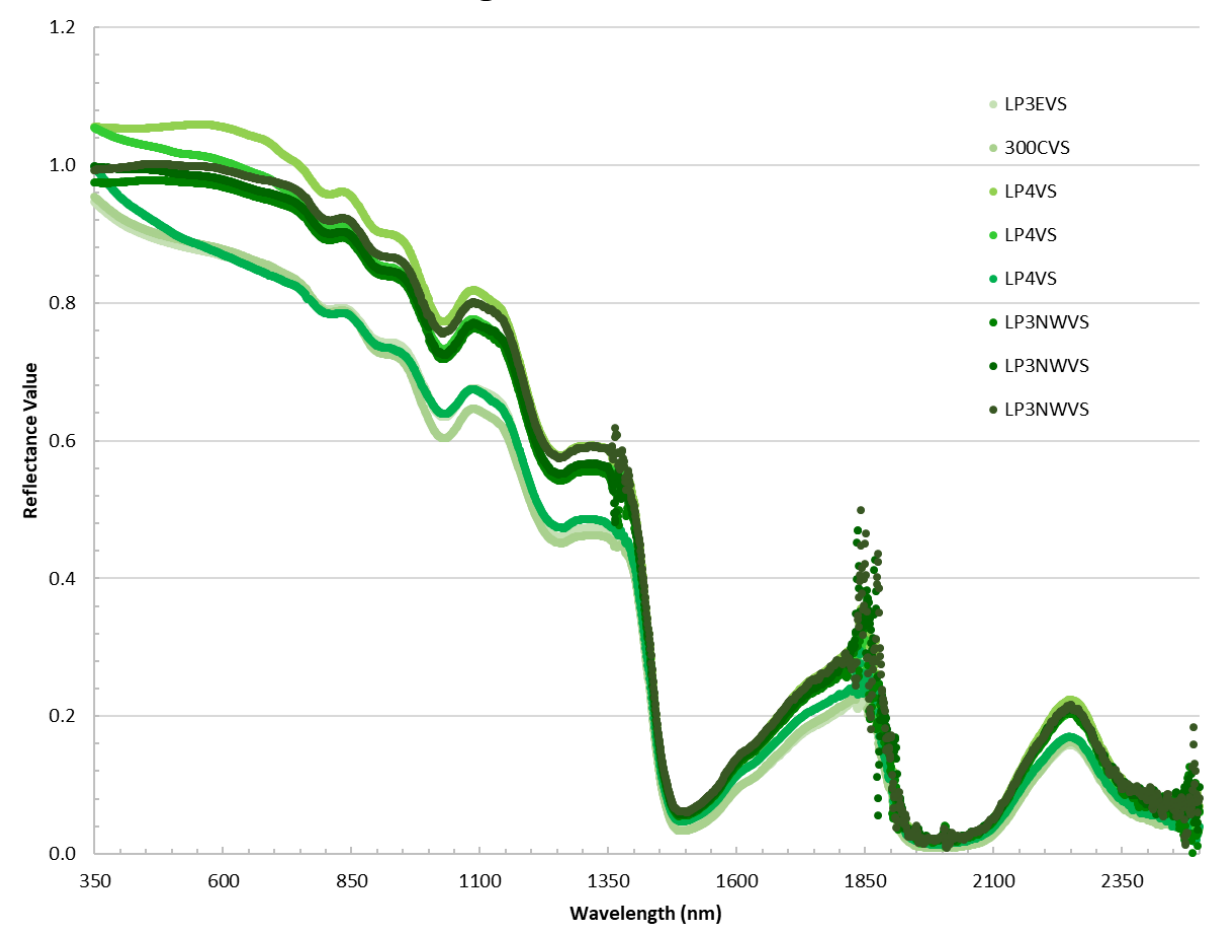

Figures 42 and 43 show characteristic spectral shapes of the different surfaces. Figure 43 shows a more detailed view of the $800-1200 \mathrm{~nm}$ wavelengths to highlight that the groomed snow and virgin snow surfaces are not distinguishable even at the higher wavelengths. While the wet and dry asphalt and the smooth and grooved ice are clearly distinguishable, the groomed snow (blue lines) falls within the scatter of the virgin snow (green line) surfaces.

Figure 44 more clearly shows a representative spectra from a groomed snow surface (Spin Up Pad 2) falling directly within the range of those measured on virgin snow. This finding was unexpected. The upper wavelengths are expected to provide more insight into the type of snow surface as these higher wavelengths are more indicative of grain size (Nolin et al. 1993; Painter et al. 1998). The groomed surfaces consisted of uniform very-fine-grained snow crystals, packed and smoothed, and therefore have a higher reflectance value than the loose, newly fallen snow. The WV2 bands also did not distinguish between the groomed and virgin snow. This indicates that future analysis is needed to isolate these higher wavelengths 
in the $\mathrm{WV}_{3}$ imagery for further evaluation. Ensuring consistent lighting conditions and a narrower sample size during collection may also help to distinguish these snow types and specific features remotely.

Figure 42. Michigan ASD field spectrometer reflectance values for asphalt (red), ice (purple), groomed snow (b/ue), and virgin snow (green) surfaces.

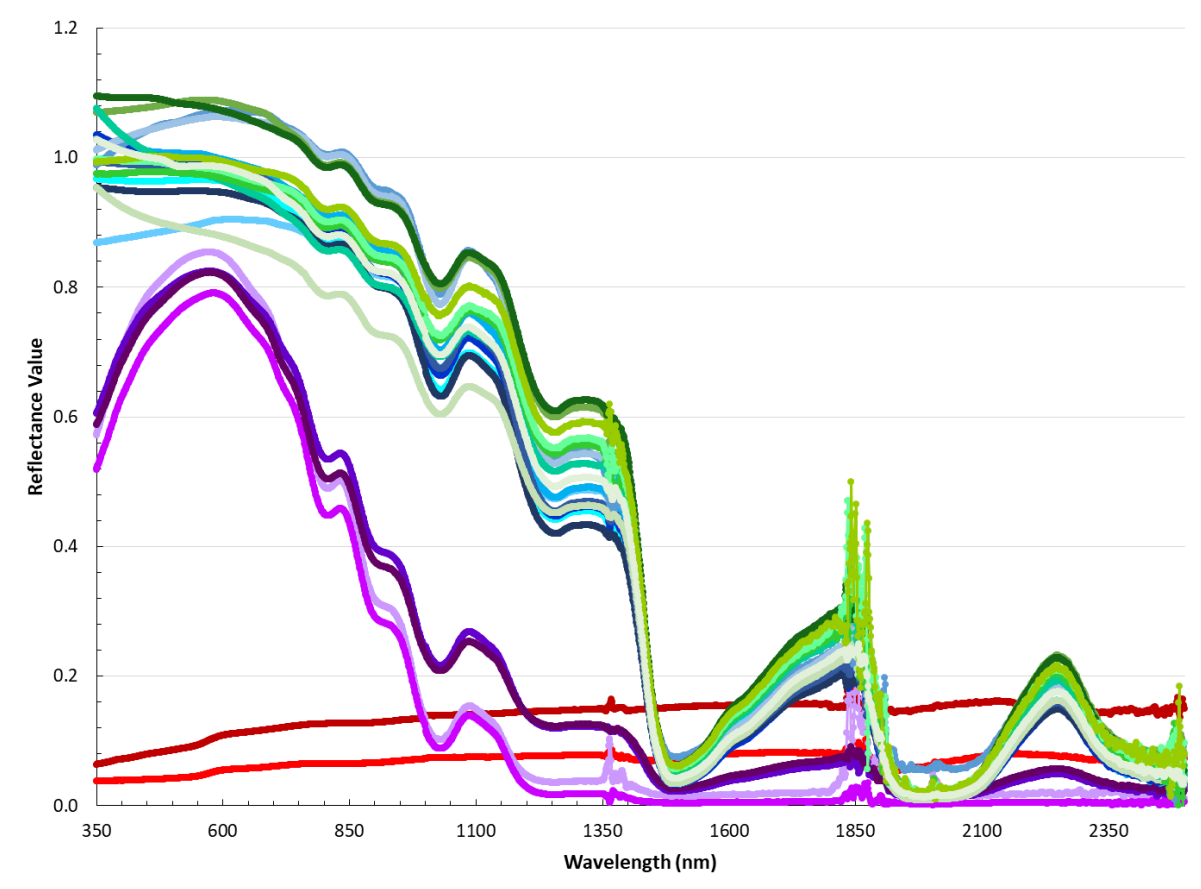

Figure 43. Michigan ASD field spectrometer reflectance values for 800$1200 \mathrm{~nm}$, for asphalt (red), ice (purple), groomed snow (b/ue), and virgin snow (green) surfaces.

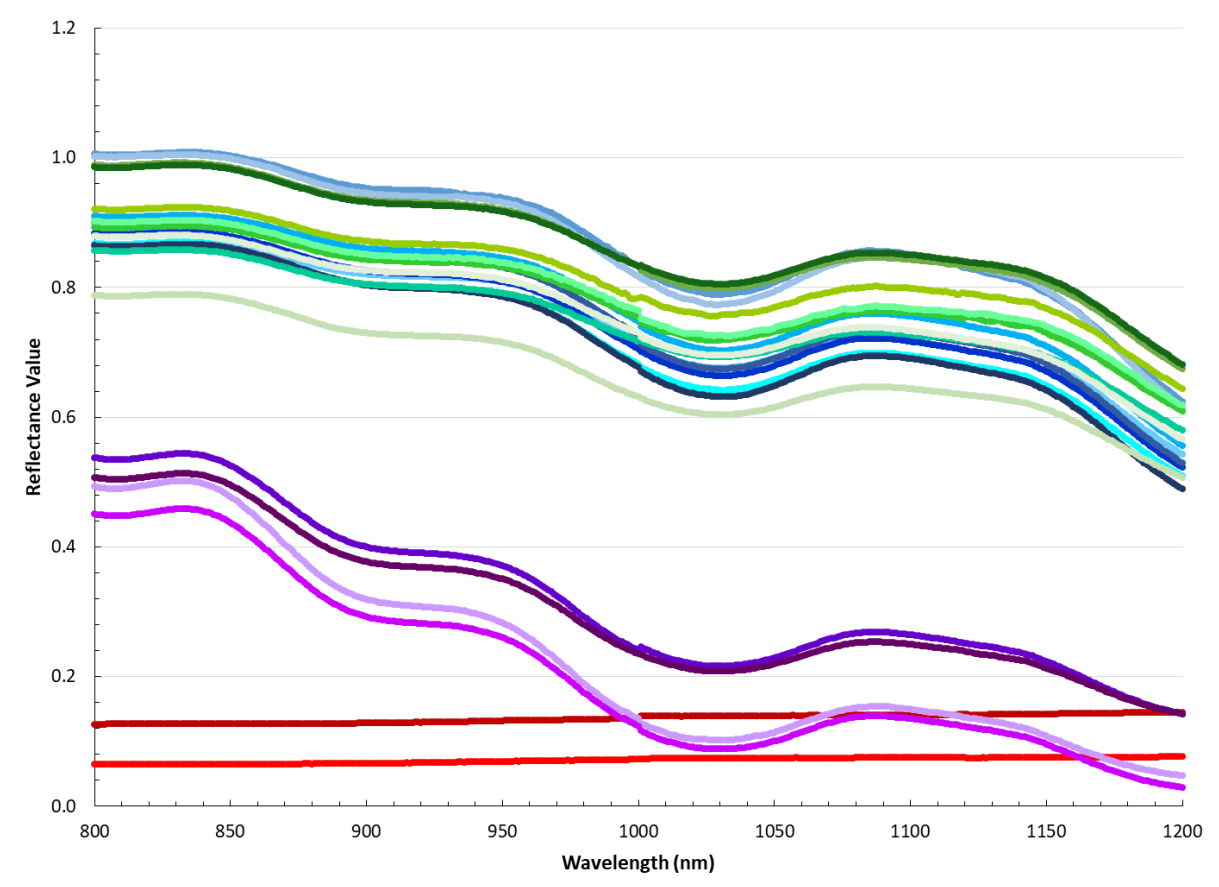


Figure 44. Michigan groomed snow (red) falls within the scatter of the undisturbed snow (various greens).

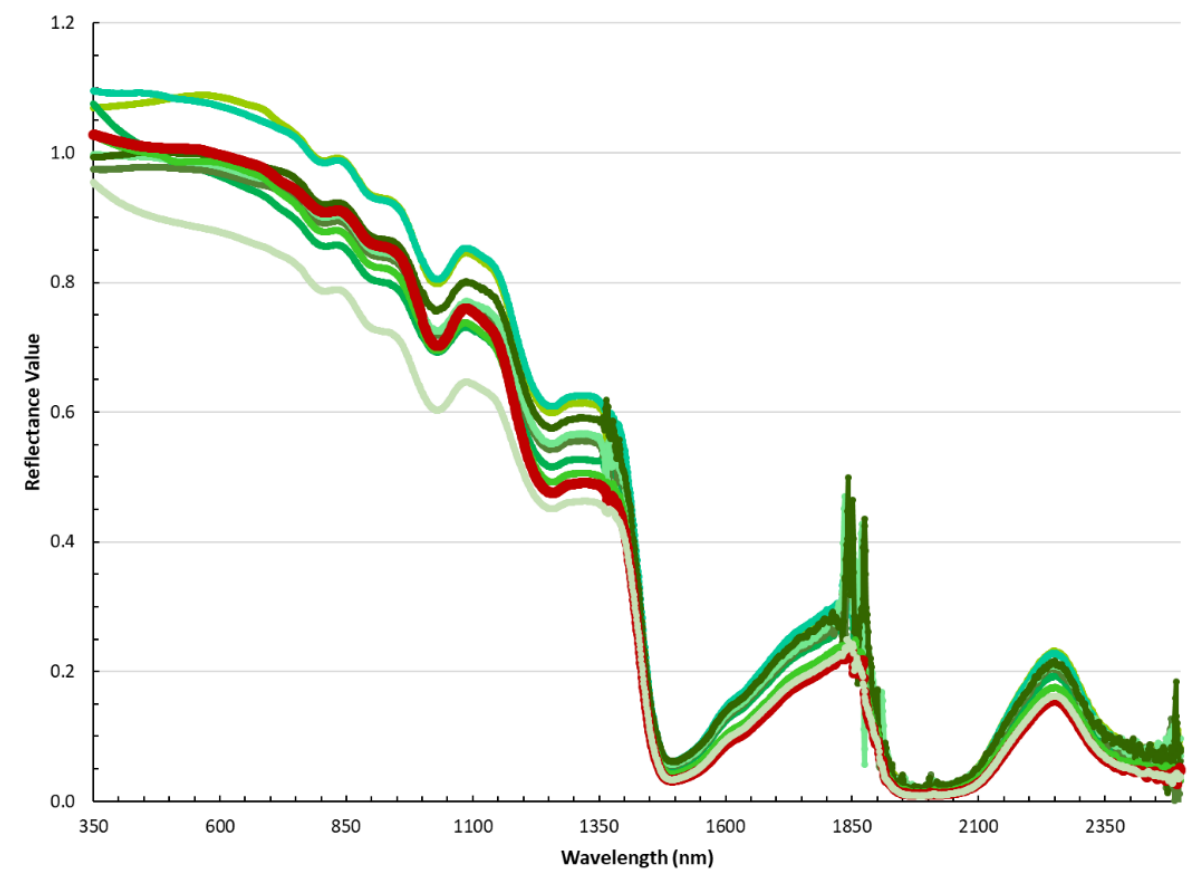

\subsection{Comparison of strength measurements with spectra data}

Lastly, we compared the WV2 spectra band values to strength measurements taken at each location. Because the WV2 spectra is a surface measurement, most show no correlation to underlying snow-strength characteristics; but two strength values that show promise are the CTI and the Yamaha drop cone, which are both very-near-surface measurements (see Figure 45). This relationship will be more fully explored in the future.

Figure 45. Plots of significant $(p<0.01)$ Spearman correlations between Michigan WV2 MS1 spectral band $(400-450 \mathrm{~nm})$ and snow strength measured with the CTI and Yamaha drop cone.
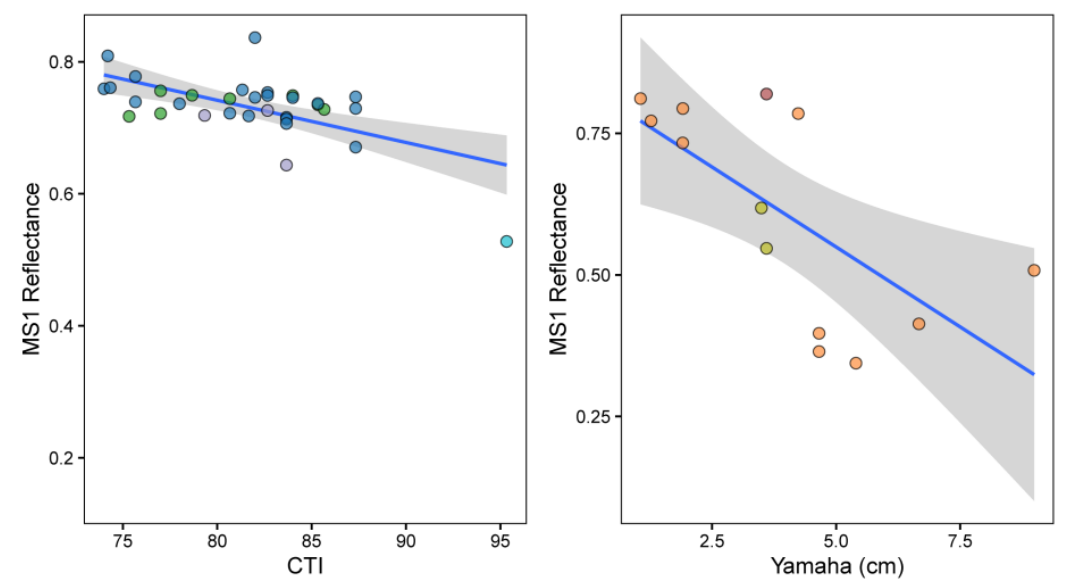

- Clear Pavement

- Groomed

- Fresh Snow over Groomed

- Ice

- Ice and New Snow over Groomed

- New Snow

- Virgin Snow

- Virgin Snow/lce 


\section{Conclusions and Recommendations for Future Work}

As the U.S. military has been fighting predominantly in the desert for 30 years, methods to optimize operations in winter and extreme conditions in northern environments are lacking. Information on the geospatial distribution of snow physical and mechanical properties is required for mobility and other force projection and sustainment tasks. Army operations require knowledge of snow distribution and properties to support mobility and maneuver activities and therefore need methods to measure and globally predict engineering snow properties in winter and extreme environments.

This portion of the BAEM project aimed to define the existing state of the art and to develop new techniques (e.g., in situ, remotely sensed, and modeled) to adequately characterize snow mechanical properties on a variety of snow types for maneuver and sustainment purposes. Two field campaigns addressed this, one in Calumet, Michigan, in February 2018 and another in West Yellowstone, Montana, in January 2018. Not all techniques were available at both sites, some techniques did not work in certain kinds of snow cover, and additional methods have since been identified for future studies. However, this field work provides a rich data set of scientific snow characterization (stratigraphy, depth, density, moisture, etc.); mechanical properties targeting both bearing-capacity-type measurement and shear strength; on-site field spectrometry; and remotely sensed imagery through $\mathrm{WV}_{2}, \mathrm{WV}_{3}$, and TSX satellite data collections.

From these data sets and analysis, the mechanical measurements could be summarized as those that work well on groomed snow (CBR, $2.25 \mathrm{~kg}$ Clegg, CTI, and RSP), those that work well on virgin snow (Yamaha drop cone, shear vane, and plate sinkage), those that are best for profiling strength (SMP, Rammsonde, and RSP), and those that would specifically benefit from modifications for use in varied snow conditions (plate sinkage, SMP, and shear vanes). Based on these results, we plan to explore additional techniques to measure shear and friction properties (e.g., spectral analysis of surface waves and surface-friction measurement equipment).

Furthermore, our analysis of the X-band satellite radar (TSX) is preliminary. Previous radar work using multiple frequencies and dual polarizations has shown a sensitivity to bulk snow properties. In the future, we 
intend to leverage satellite radar acquisitions (e.g., TSX and Sentinel) with different frequencies and polarization modes to continue our investigation toward a sensitivity to snow micromechanical properties.

Satellite-based optical remote sensing in snow-covered terrain provides multi-spectral characterization of the snow surface, and previous work has shown a relationship to snow microstructure (grain size), impurities (dust and carbon), and qualitative classifications such as snow age. In the future, we intend use these same satellites in a stereo mode where overlapping images may be processed into a digital surface model, providing a finescale (on the order of meters) characterization of the surface roughness and its impacts on mobility and maneuver.

Snow is extremely variable in its physical and mechanical properties and can change drastically temporally and spatially and perhaps most significantly with loading and changes in temperature. Our data collection included a wide range of snow types to assess which techniques worked best in specific conditions and which techniques worked across a wide range of conditions. We also aimed to collect data at very different geographic locations (western snow adjacent to mountainous terrain and eastern snow adjacent to a major waterbody).

Preliminary analysis of the results indicate

1. some correlation between strength measures, especially when grouped based on the snow-surface type;

2. some strength measures did not seem useful for characterizing snow for vehicle mobility purposes; and

3. trends between visible and near-infrared snow spectra and some surface strength measurements.

There are many questions regarding the use of some of the more sophisticated measurements that have not previously been used in the cold or in snow. Some of the instruments seemed to drift with temperature, even after a period of approximately 1 hour for temperature equilibration; and others contained components that were not well suited for use in cold (e.g., differential contraction of materials leading to poor fit of components). These were evaluated more thoroughly in controlled cold room testing to develop operational techniques and equipment modifications as needed (Menke et al. 2019). Shear vanes and their associated equations 
also need to be modified for vane sizes better suited to a variety of snow surfaces. The depth of influence of several tests needs to be investigated to determine what material, the snow or the underlying surface, is actually being evaluated.

The 2018 field data collection provides a rich data set for further analysis, particularly for relating strength and remotely sensed measurements, in addition to helping refine future data collection objectives. These data will be further analyzed in FY19 to

1. assess in situ micromechanical properties of snow (e.g., SMP and GPR data sets) from the January 2018 campaign and the correlation of these data with coordinated satellite-based radar acquisitions (at X-band and Cband);

2. provide a basis for detailed exploration of temperature effects on some of the equipment components to fully understand operating techniques for cold environments;

3. further explore the statistical and theoretical relationship of snow physical and mechanical properties to remotely sensed data; and

4. develop a new SMP prototype for applications in "hard" snow conditions (e.g., for mobility), including incorporating a higher capacity force sensor, an embedded Linux platform for instrument control, display and data logging capabilities, and the associated hardware and software required for accurate measurements.

Experiments planned for FY19 focus on assessing and refining new field in situ and remote techniques:

1. Developing operation guidance for low-temperature evaluation of new techniques for bearing capability, shear modulus, and friction measurement through cold room experiments

2. Assessing the most promising suite of instruments on a controlled, groomed snow airfield test section in the Frost Effects Research Facility

3. Conducting snow mobility experiments to expand the mechanistic observations and performance database of modern vehicle operations in a variety of snow surfaces

4. Leveraging the NASA (National Air and Space Administration) SnowEx experiments by adding mechanical property and stand-off measurements 
at select field sites being monitored by NASA ground and satellite collections and supplemented with the CRREL Helipod instrumentation package that leverages lidar, thermal, and optical remote-sensing opportunities

5. Exploring a mechanistic approach to snow mobility modeling and methodology to incorporate simple terramechanics into a geospatial framework, especially needed for deep snow mobility (Shoop et al. 2019a)

6. Creating remote-sensing algorithms to estimate spatial variability of snow density, to be used as a proxy for snow mechanical properties

Future work will integrate enhancements to snow physics algorithms and satellite-based remote-sensing techniques specifically focused on snow mechanical properties, such as compactive behavior, modulus, bearing, and shear strength, and will develop algorithms to capture this behavior within the framework of cross-country mobility models. We will also be looking at methods to geospatially distribute these types of snow properties for use in maneuver and sustainment analysis (Deeb et al. 2019). These efforts will provide critical scientific and engineering data and models to enable maneuver support and sustainment planning for all-season capabilities in northern environments. 


\section{References}

Abele, G. 1963. A Correlation of Unconfined Compressive Strength and Ram Hardness of Processed Snow. Technical Report 85. Hanover, NH: U.S. Army Cold Regions Research and Engineering Laboratory.

- 1968. An Experimental Snow Runway Pavement in Antarctica. Technical Report 211. Hanover, NH: U.S. Army Cold Regions Research and Engineering Laboratory.

- 1990. Snow Roads and Runways. Monograph 90-3. Hanover, NH: U.S. Army Cold Regions Research and Engineering Laboratory.

AMS. 2018. Part \#59035 GeoTester Penetrometer Technical Data Sheet. American Falls, ID: AMS, Inc. http://www.ams-samplers.com/.

ASTM. 2010. Standard Test Method for CBR (California Bearing Ratio) of Soils in Place. ASTM D4429-09a. West Conshohocken, PA: ASTM International. https://www.astm.org/Standards/D4429.htm.

- 2016a. Standard Test Methods for Determination of the Impact Value (IV) of a Soil. ASTM D5874-16. West Conshohocken, PA: ASTM International. https://www.astm.org/Standards/D5874.htm.

- 2016b. Standard Test Methods for Single Wheel Driving Traction in a Straight Line on Snow- and Ice-Covered Surfaces. ASTM F1805-16. West Conshohocken, PA: ASTM International. https://www.astm.org/Standards/F1805.htm.

- 2018. Standard Test Method for Field Vane Shear Test in Saturated Fine-Grained Soils. ASTM D2573-18. West Conshohocken, PA: ASTM International. https://www.astm.org/Standards/D2573.htm.

Blaisdell, G. L., V. Klokov, and D. Diemand. 1995. "Compacted Snow Runway Technology on the Ross Ice Shelf Near McMurdo, Antarctica." Contributions to Antarctic Research IV 67:153-173.

Carroll, T. 1977. "A Comparison of the CRREL $500 \mathrm{~cm}^{3}$ Tube and the ILTS 200 and $100 \mathrm{~cm}^{3}$ Box Cutters Used for Determining Snow Densities." Journal of Glaciology 18 (79): 334-337.

Clegg, B. 1980. “An Impact Soil Test as Alternative to California Bearing Ratio.” In Proceedings, 3rd Australian-New Zealand (ANZ) Geomechanics Conference, Wellington, New Zealand, 1:225-230.

Conger, S. M., and D. M. McClung. 2009. "Comparison of Density Cutters for Snow Profile Observations.” Journal of Glaciology 55 (189): 163-169.

Conover, W. J., and R. L. Iman. 1979. On Multiple-Comparisons Procedures. LA-7677MS. Los Alamos, NM: Los Alamos Scientific Laboratory. 
Deeb, E., C. Polashenski, Z. Courville, C. Hiemstra, A. Wagner, J. Eylander, and R. Davis. 2019. "Geospatial Snow Estimation for Engineering Applications and Operations." In Proceedings of the International Conference on Cold Regions Engineering, 18-22 August, Quebec City, Quebec, Canada. Reston, VA: American Society of Civil Engineers.

Denoth, A. 1989. "Snow Dielectric Measurements." Advances in Space Research 9 (1): 233-243.

DigitalGlobe. 2012. WorldView-2. Data Sheet DS-WV2 Rev 6/12. Westminster, CO: DigitalGlobe.

- - 2014. DigitalGlobe Constellation >> WorldView-3. Data Sheet DS-WV3 05/14. Westminster, CO: DigitalGlobe.

Elder, B., S. Shoop, M. Feyrer, and S. Beal. 2019. "Methods for Measuring Snow Moisture and Density." In Proceedings of the International Conference on Cold Regions Engineering, 18-22 August, Quebec City, Quebec, Canada. Reston, VA: American Society of Civil Engineers.

Feyrer, M., J. Balch, B. Elder, and S. Shoop. 2018. "Methods for Measuring Snow Moisture and Density." Poster presented at the CRREL Student Poster Session, August 2018, Hanover, NH, U.S. Army Engineer Research and Development Center.

Kruse, F. A. 2015. Final Report: Soil Characterization Using Spectral Measurements. NPS/CRREL FY15 Collaboration. Monterey, CA: Naval Postgraduate School, Remote Sensing Center.

Longbotham, N., F. Pacifici, B. Baugh, and G. Camps-Valls. 2014. "Prelaunch Assessment of WorldView-3 Information Content." In IEEE GRSS Workshop on Hyperspectral Image and Signal Processing (WHISPERS), 479-486.

Marshall, H.-P., and J. B. Johnson. 2009. "Accurate Inversion of High-Resolution Snow Penetrometer Signals for Microstructural and Micromechanical Properties.” Journal of Geophysical Research 114 (F4): Fo4016. https://doi.org/10.1029/2009JF001269.

Matzl, M., and M. Schneebeli. 2006. "Measuring Specific Surface Area of Snow by NearInfrared Photography.” Journal of Glaciology 52 (179): 558-564. https://doi.org/10.3189/172756506781828412.

Meehan, T., H. P. Marshall, E. Deeb, S. Shoop. 2019a. SnowMicroPenetrometer Applications for Winter Vehicle Mobility. ERDC/CRREL TR-19-14. Hanover, NH: U.S. Army Engineer Research and Development Center.

—_. 2019b. "SnowMicroPenetrometer Applications for Winter Vehicle Mobility." In Proceedings of the International Conference on Cold Regions Engineering, 1822 August, Quebec City, Quebec, Canada. Reston, VA: American Society of Civil Engineers. 
Menke, A., W. Wieder, and S. Shoop. 2019. "Using the Light Weight Deflectometer in Winter Climates." In Proceedings of the International Conference on Cold Regions Engineering, 18-22 August, Quebec City, Quebec, Canada. Reston, VA: American Society of Civil Engineers.

Millar, L. R. 1977. “Application of the Soil Impact Tester to Road Pavement Construction." Honors Thesis, Department of Civil Engineering, University of Western Australia, Crawley, Western Australia.

Nolin, A. W., J. Dozier, and L. A. K. Mertes. 1993. "Mapping Alpine Snow Using a Spectral Mixture Modeling Technique.” Annals of Glaciology 17:121-124.

Painter, T. H., D. A. Roberts, R. O. Green, and J. Dozier. 1998. "The Effect of Grain Size on Spectral Mixture Analysis of Snow-Covered Area from AVIRIS Data." Remote Sensing of Environment 65 (3): 320-332. https://doi.org/10.1016/S00344257(98)00041-8.

Painter, T. H., J. Dozier, D. A. Roberts, R. E. Davis, and R. O. Green. 2003. "Retrieval of Subpixel Snow-Covered Area and Grain Size from Imaging Spectrometer Data." Remote Sensing of Environment 85 (1): 64-77. https://doi.org/10.1016/S00344257(02)00187-6.

Painter, T. H., K. Rittger, C. McKenzie, P. Slaughter, R. E. Davis, and J. Dozier. 2009. "Retrieval of Subpixel Snow Covered Area, Grainsize, and Albedo from MODIS." Remote Sensing of Environment 113 (4): 868-879. https://doi.org/10.1016/i.rse.2009.01.001.

Pielmeier, C., and M. Schneebeli. 2003. "Stratigraphy and Changes in Hardness of Snow Measured by Hand, Ramsonde and Snow Micro Penetrometer: A Comparison with Planar Sections." Cold Regions Science and Technology 37 (3): 393-405. https://doi.org/10.1016/S0165-232X(03)00079-X.

R Core Team. 2017. R: A Language and Environment for Statistical Computing. Vienna, Austria: R Foundation for Statistical Computing. https://www.R-project.org/.

Schneebeli, M., and J. B. Johnson. 1998. "A Constant-Speed Penetrometer for HighResolution Snow Stratigraphy.” Annals of Glaciology 26:107-111. https://doi.org/10.3189/1998AoG26-1-107-111.

Senseney, C. T., and M. A. Mooney. 2010. "Characterization of Two-Layer Soil System Using a Lightweight Deflectometer with Radial Sensors.” Transportation Research Record: Journal of the Transportation Research Board 2186:21-28. https://doi.org/10.3141/2186-03.

Shaw, G. A., and H. K. Burke. 2003. "Spectral Imaging for Remote Sensing.” Lincoln Laboratory Journal 14 (1): 3-28.

Shoop, S. A., J. Crandell, and M. Knuth. 2012. "Using a Clegg Impact Hammer to Measure Snow Strength.” In Proceeding of the 15th International Conference on Cold Regions Engineering, Quebec, Canada, 19-22 August, 811-822. 
Shoop, S., W. Wieder, and B. Elder. 2019a. "Mechanical Property Measurements on Various Snow Surfaces." In Proceedings of the International Conference on Cold Regions Engineering, 18-22 August, Quebec City, Quebec, Canada. Reston, VA: American Society of Civil Engineers.

Shoop, S., M. Bodie, S. Frankenstein, M. Parker, and M. Bigl. 2019b. "Recent Improvements to Snow Mobility Algorithms.” In Proceedings of the 15th ISTVS European-African Regional Conference, 9-11 September 2019, Prague, Czech Republic.

Sturm, M., and J. Holmgren. 1999. Self-Record Snow Depth Probe. U.S. Patent US5864059A, filed 9 June 1997.

Tiuri, M., and A. Sihvola. 1986. "Snow Fork for Field Determination of the Density and Wetness Profiles of a Snow Pack.” In Hydrologic Applications of Space Technology (Proceedings of the Cocoa Beach Workshop, Florida, August 1985), IAHS Publ. no. 160.

U.S. Army and Air Force. 1994. Planning and Design of Roads, Airfield, and Heliports in the Theater of Operations-Road Design. FM 5-430-00-1. AFJPAM 32-8013, Vol. 1. Washington, DC: Department of the Army and Department of the Air Force.

U.S. Army, Air Force, and Navy. 1987. Materials Testing. FM 5-530, AFM 89-3, and NAVFAC MO-330. Washington, DC: Department of the Army, Department of the Air Force, and Department of the Navy.

Wallace, J. M., and P. V. Hobbs. 1977. Atmospheric Science: An Introductory Survey. New York: Academic Press.

Wieder, W. L., S. A. Shoop, and L. Barna. 2019. Using the Light Weight Deflectometer to Assess Groomed Snow and Ice Surfaces. ERDC/CRREL TR-19-5. Hanover, NH: U.S. Army Engineer Research and Development Center. 


\section{Appendix A: Additional Site Imagery}

Figure A-1. West Yellowstone Airport central runway, taxiway, and ice lane test points as they relate to the airport pavement surfaces.

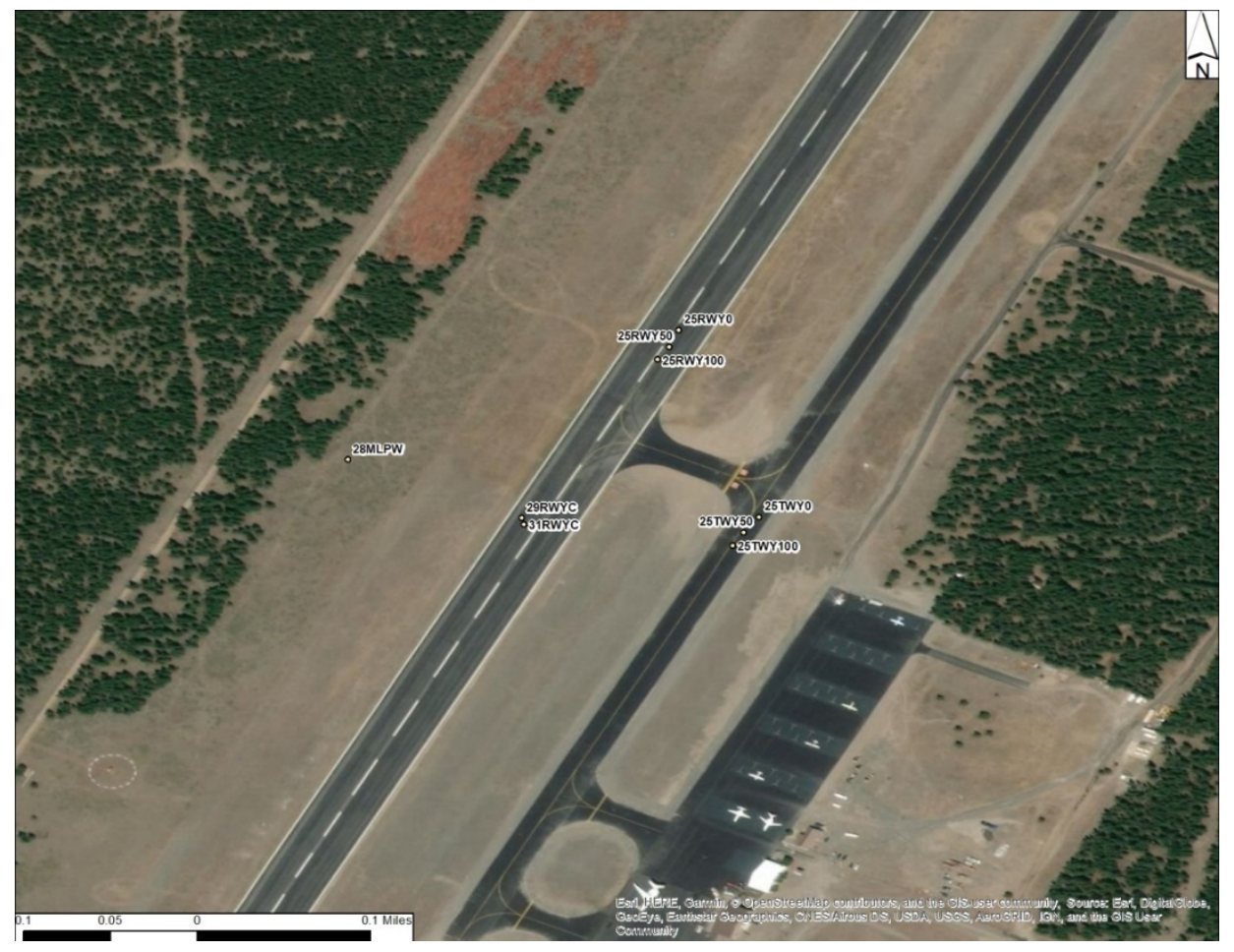

Figure A-2. Michigan Spin Up Pads 1 and 2 test points.

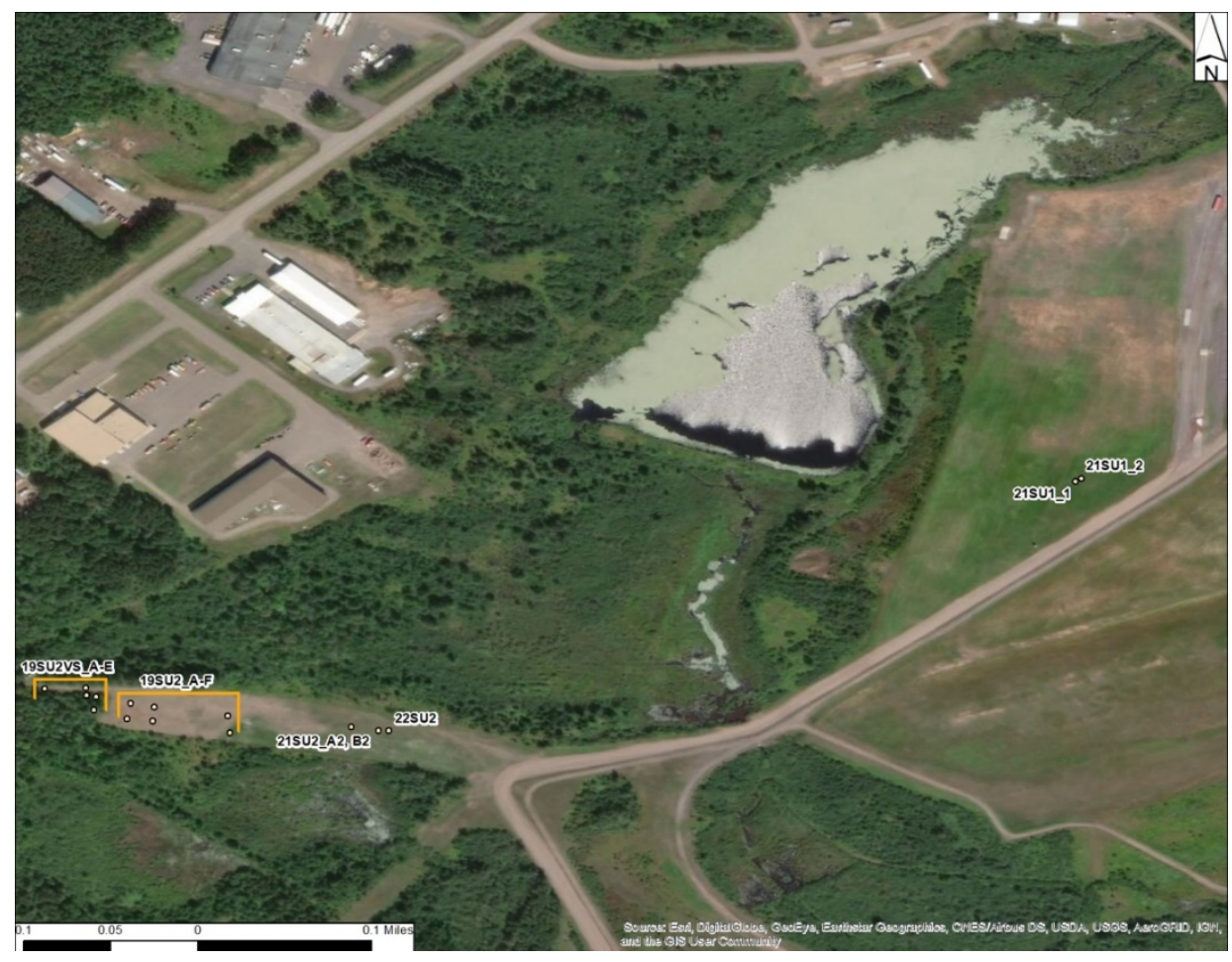


Figure A-3. Michigan Spin Up Pads 1 and 2 test points winter imagery.

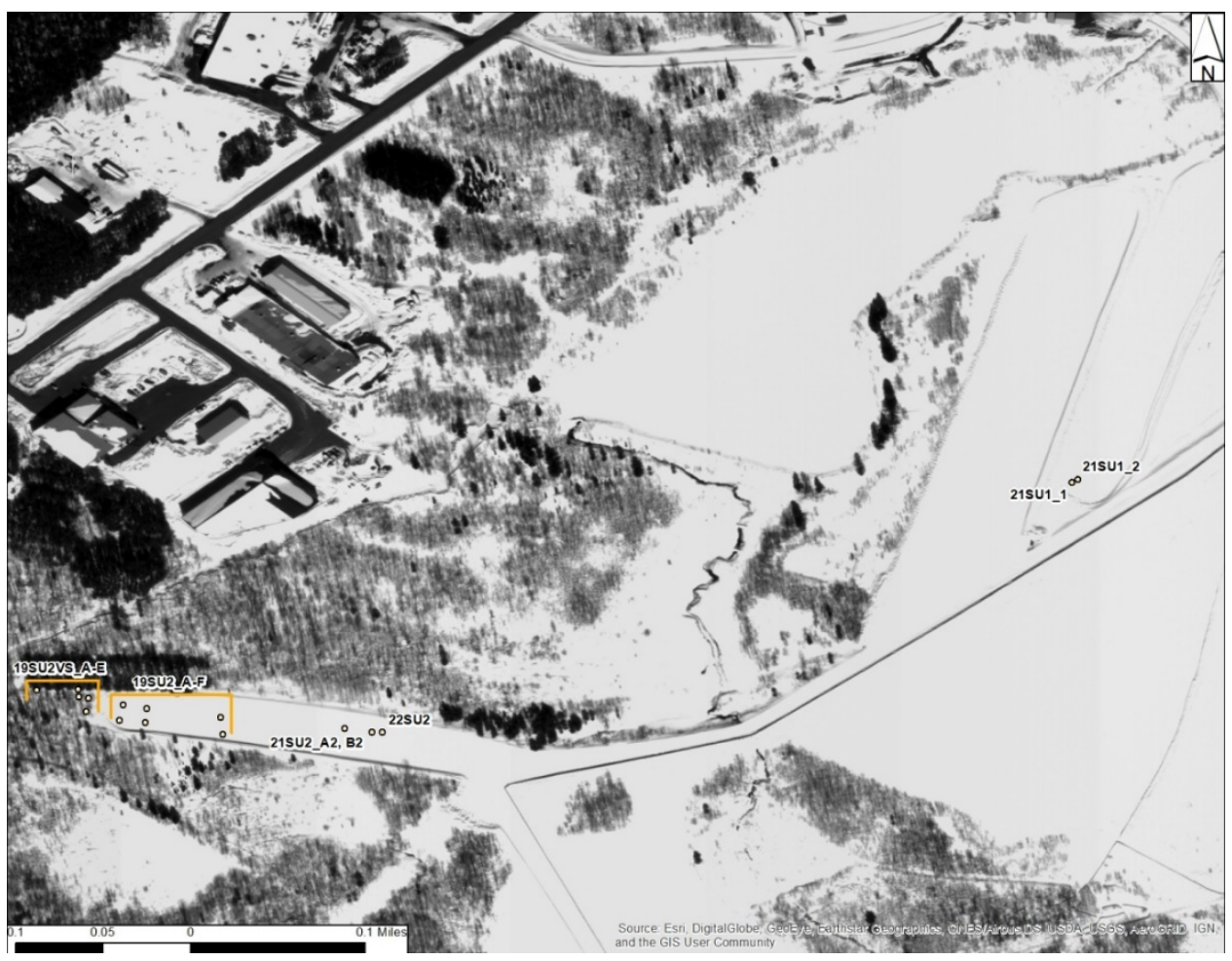

Figure A-4. Michigan Spin Up Pad 3, Loop 1, Vehicle Dynamics Area 2, and the 900 and $300 \mathrm{ft}$ circles test points.

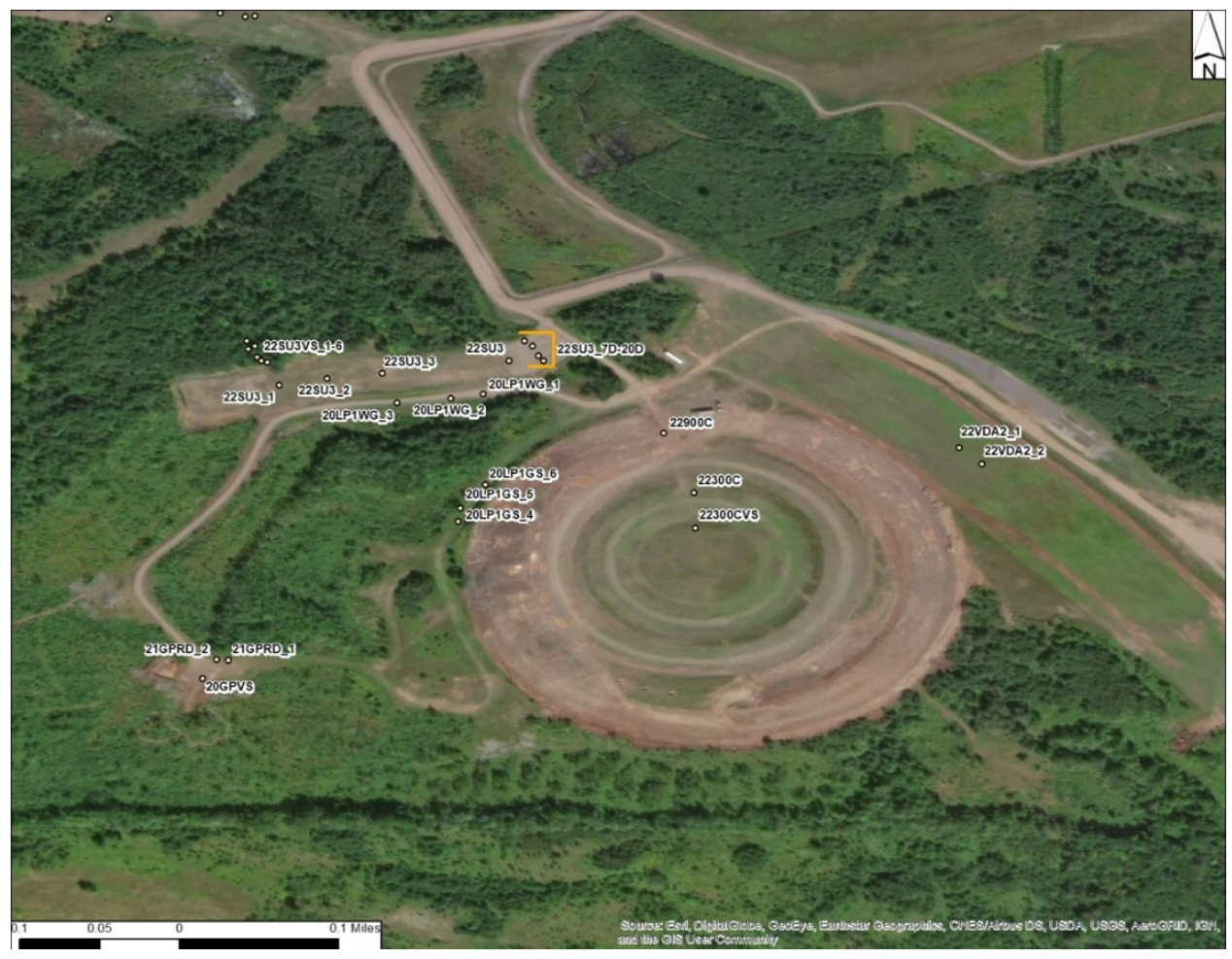


Figure A-5. Michigan Spin Up Pad 3, Loop 1, Vehicle Dynamics Area 2, and the 900 and $300 \mathrm{ft}$ circles test points winter imagery.

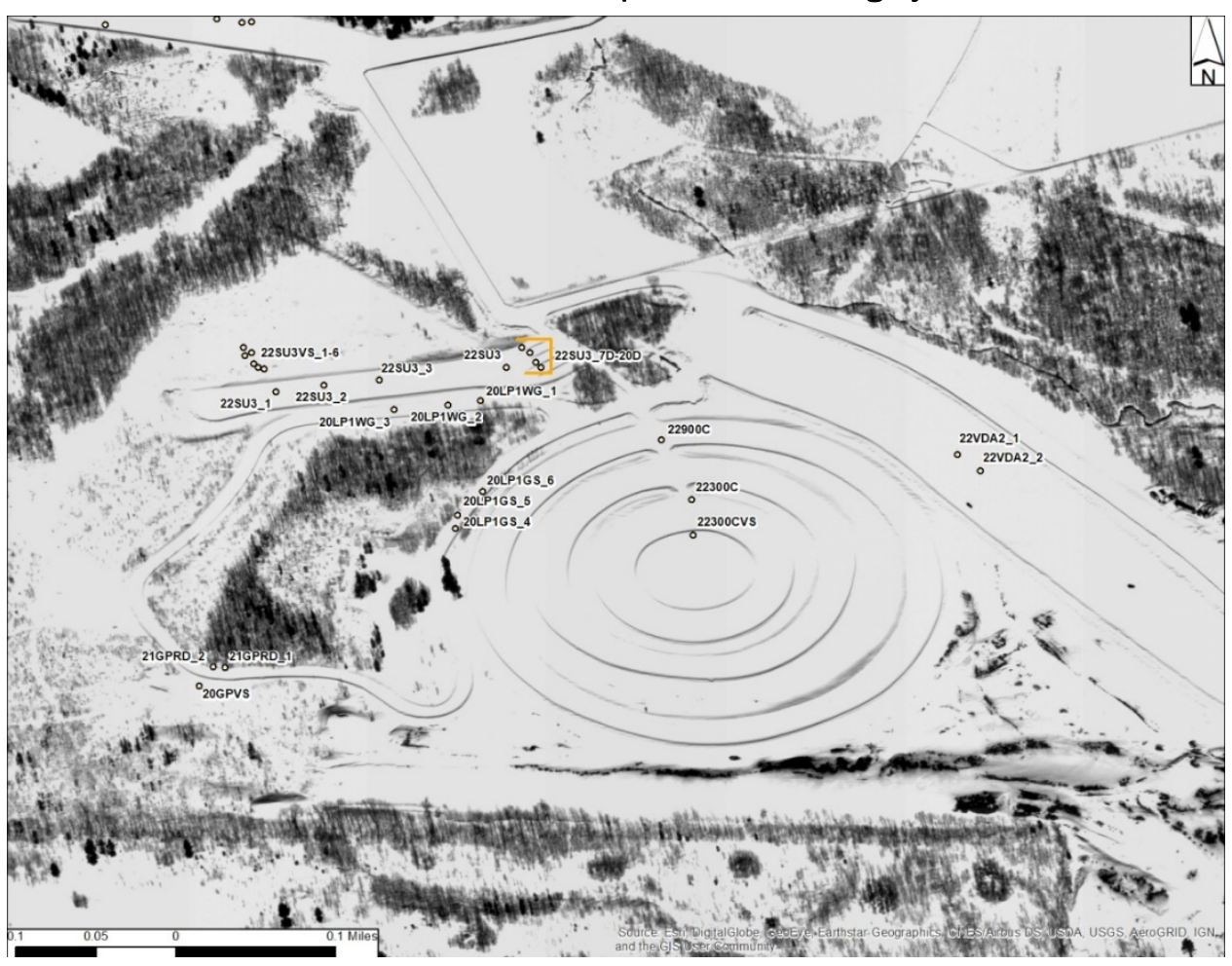

Figure A-6. Michigan Ice Rink and Sweeper parking pad test points.

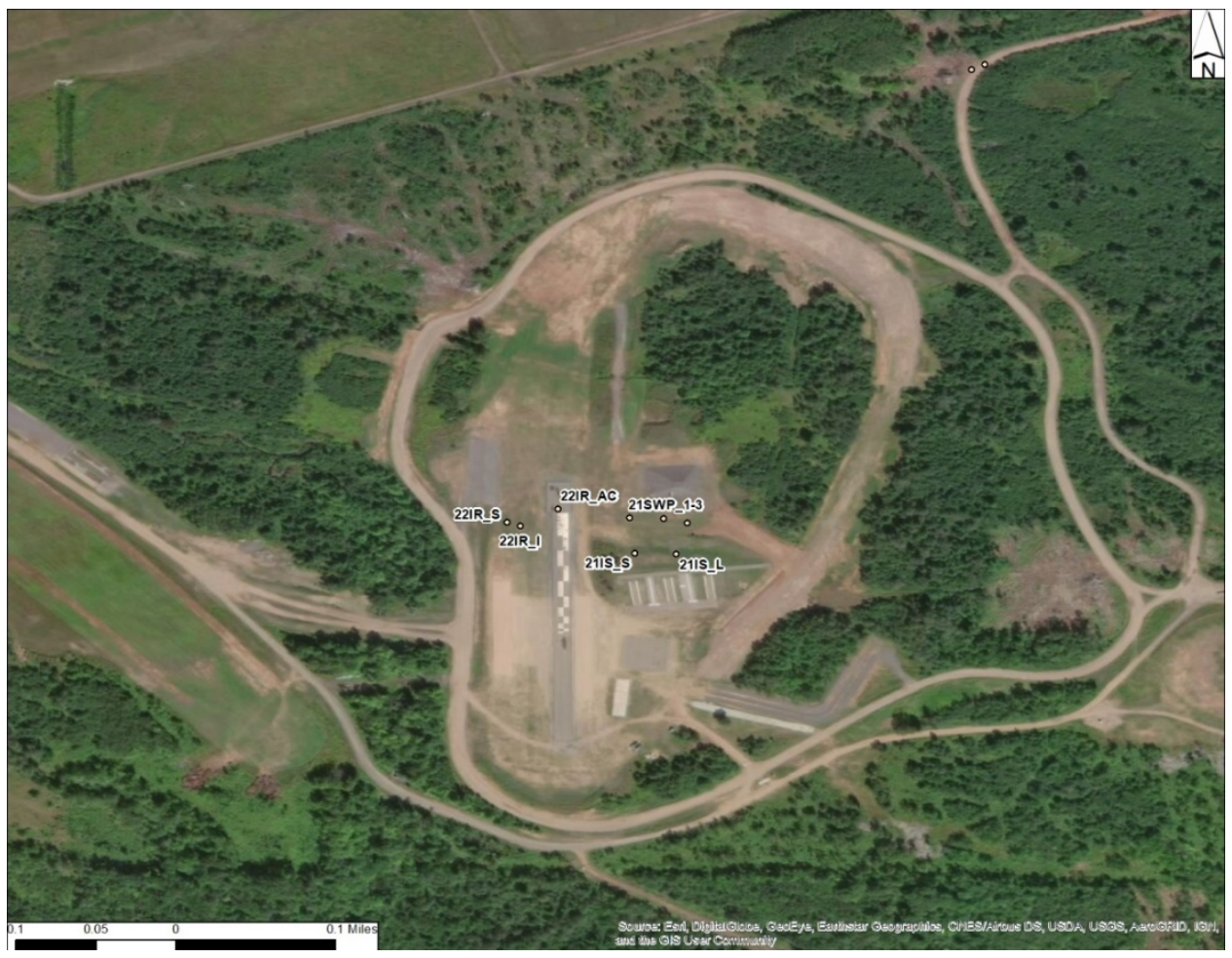


Figure A-7. Michigan Ice Rink and Sweeper parking pad test points winter imagery.

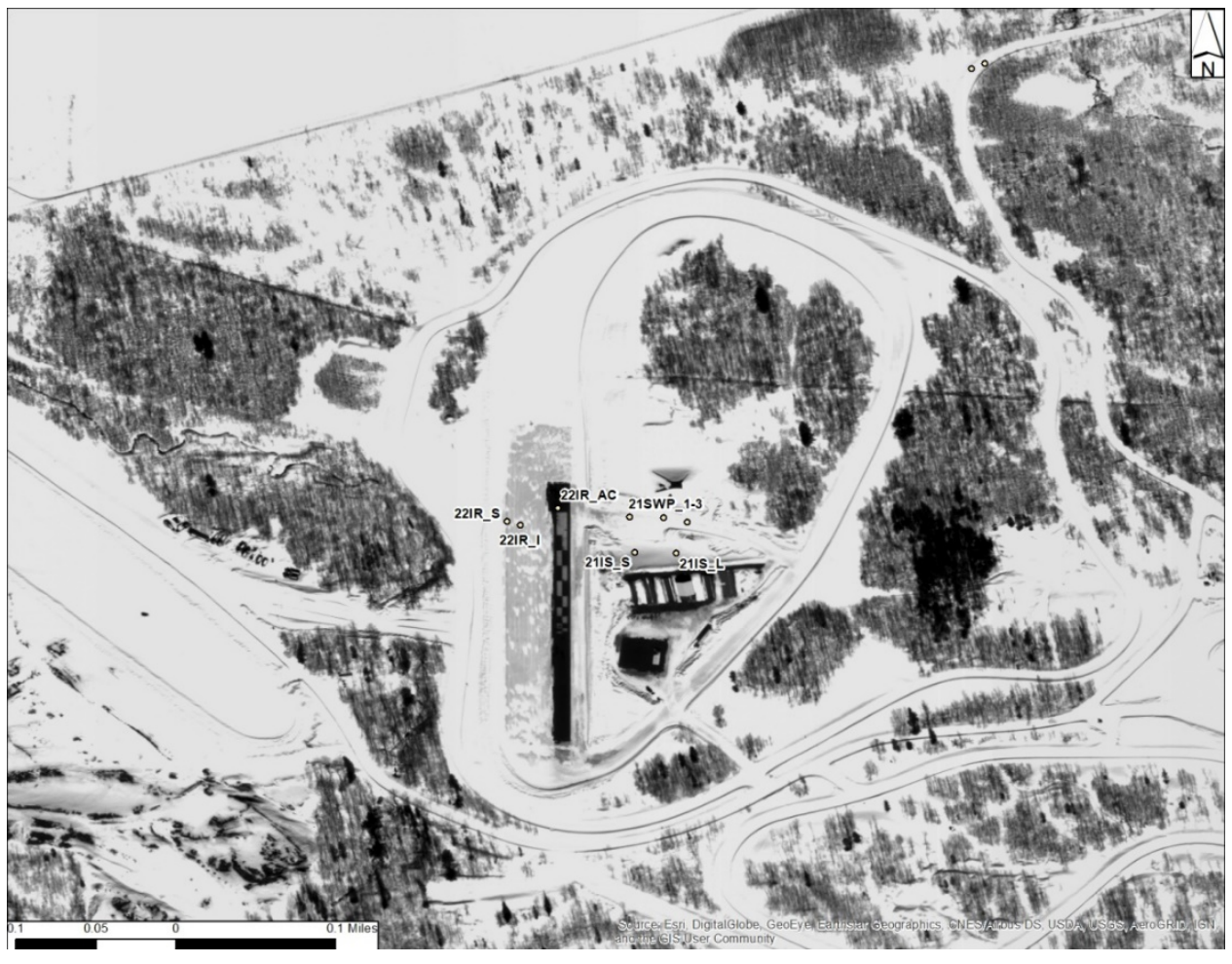

Figure A-8. Michigan Loop 3, Stability Area, and Loop 4 test points.

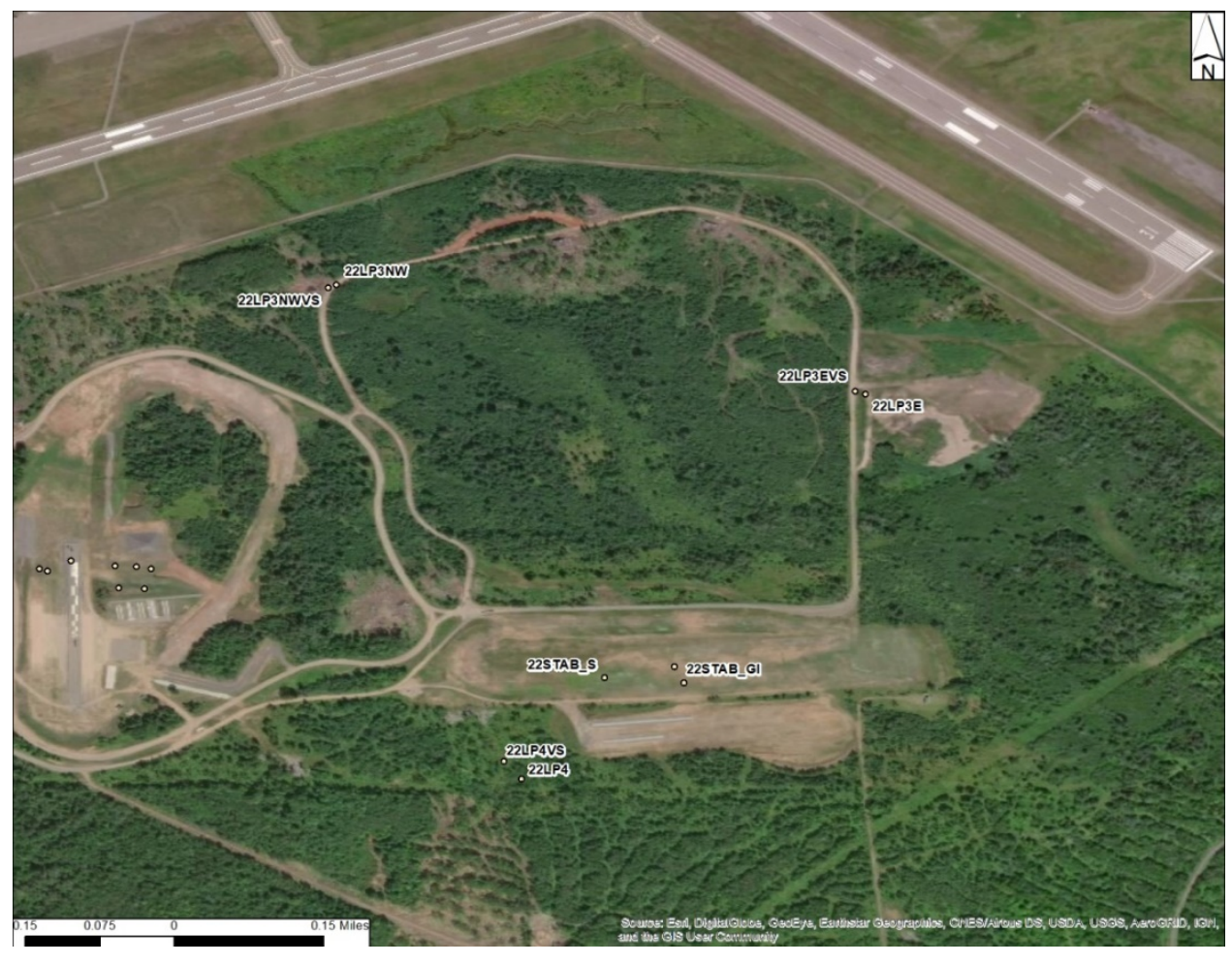


Figure A-9. Michigan Loop 3, Stability Area, and Loop 4 test points winter imagery.

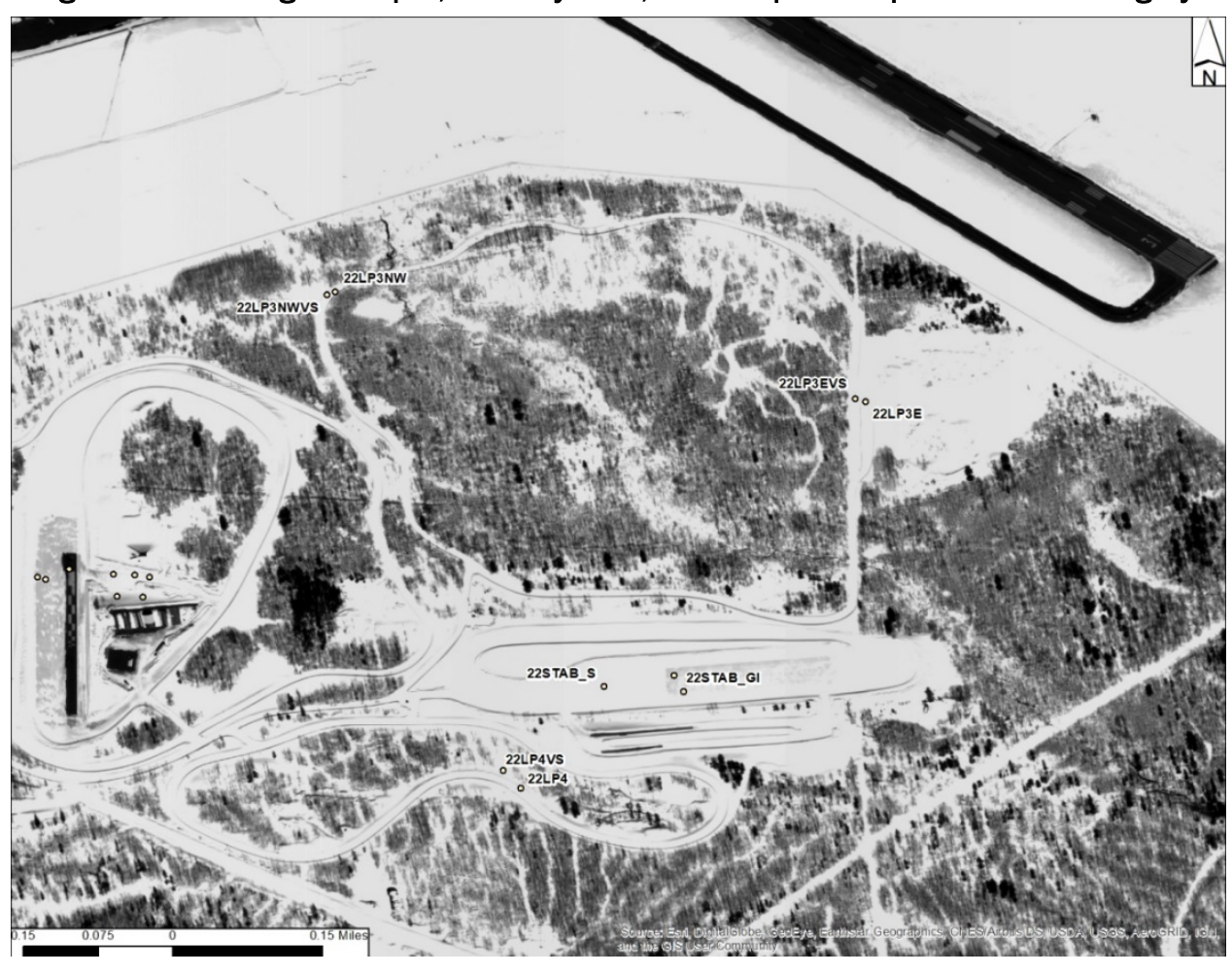




\section{Appendix B: Michigan Ground-Surface Photos}

Figure B-1. Spin Up Pad 2 (points 19SU2_A through F, 21SU2, 22SU2). Note that the bottom photo looks out into the wooded area of points 19SU2VS_A through E.
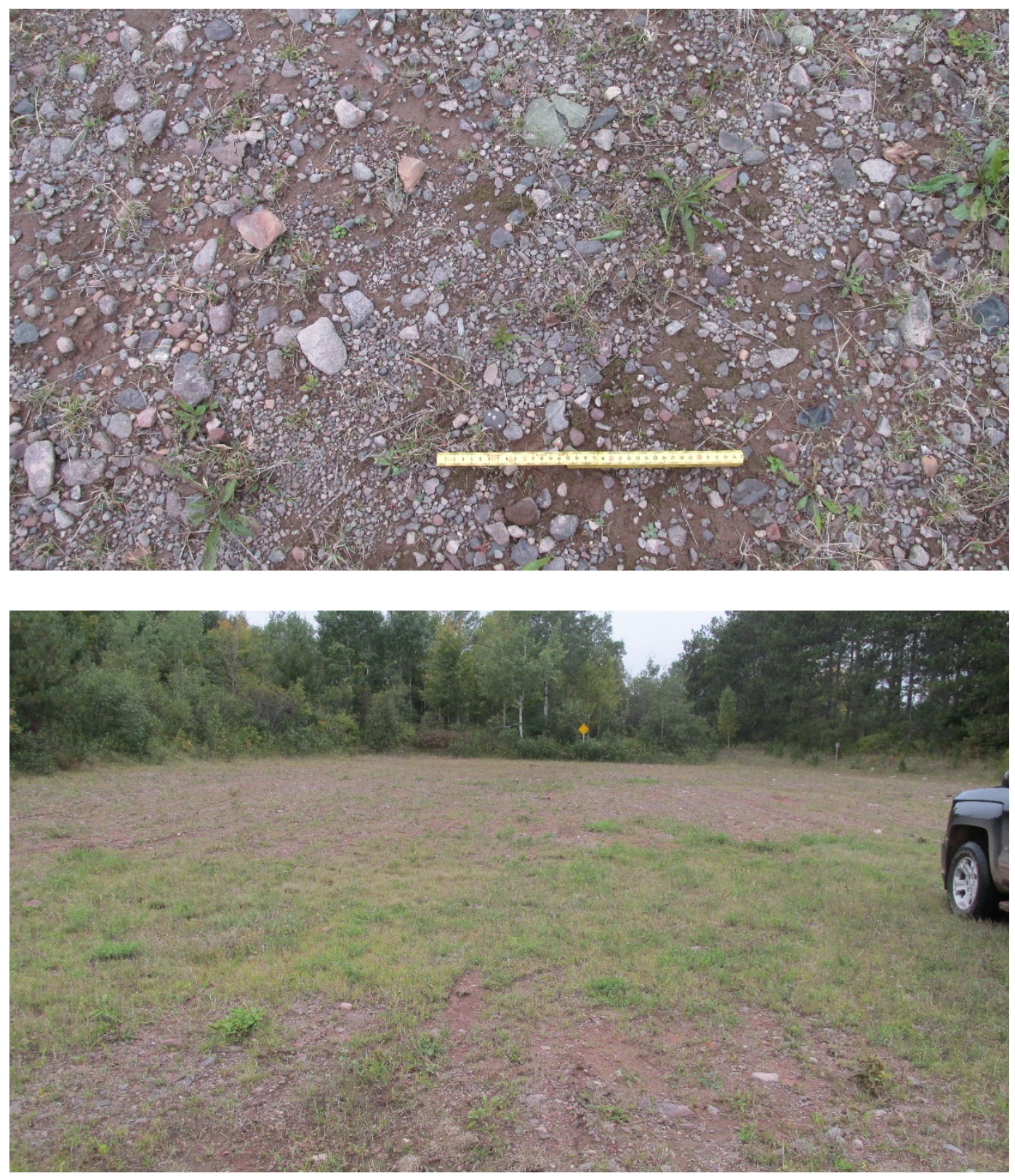
Figure B-2. Loop 1 washed gravel road (points 20LP1WG_1 through 3).
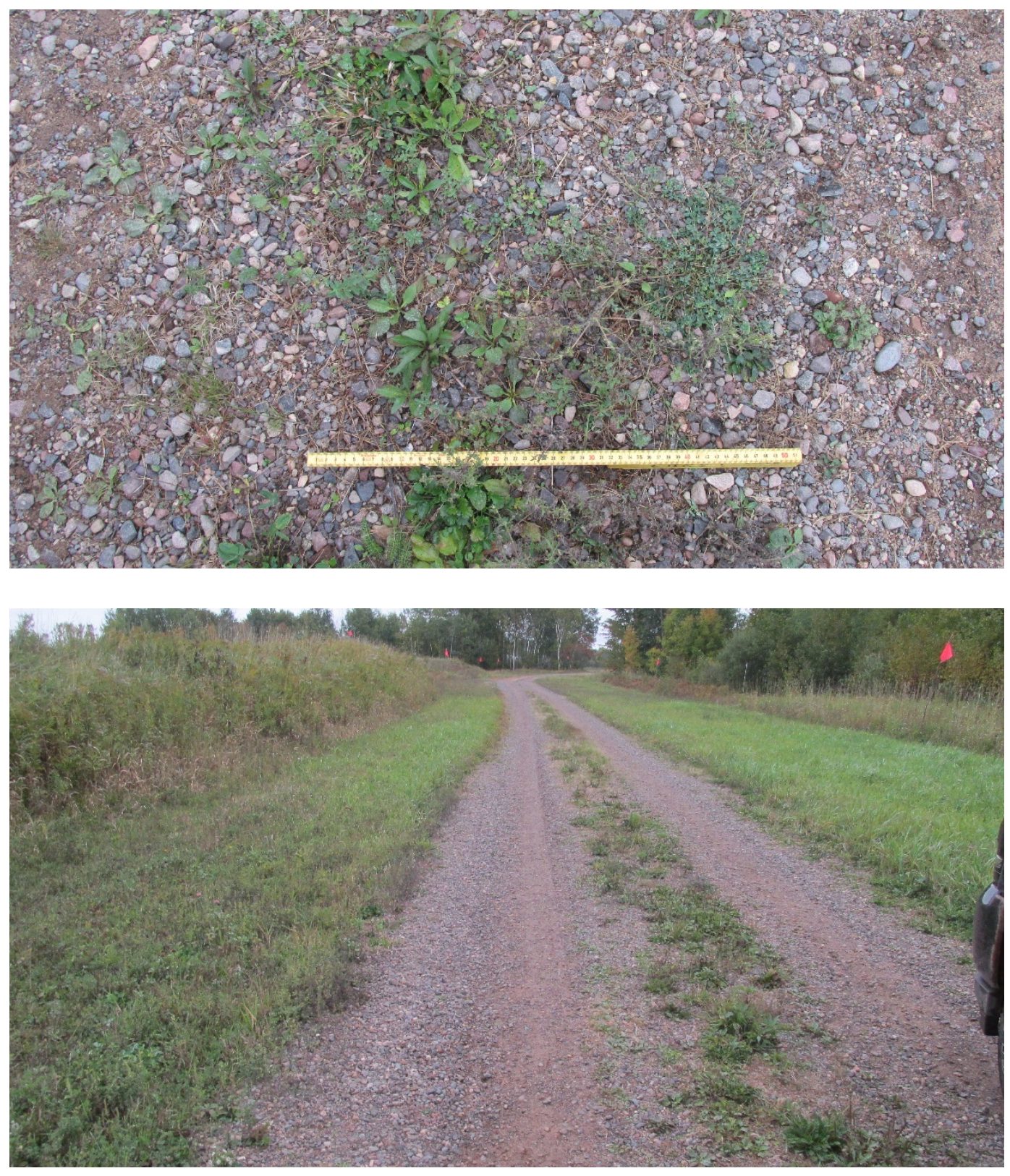
Figure B-3. Loop 1 grass-surfaced road (points 20LP1GS_4 through 6).
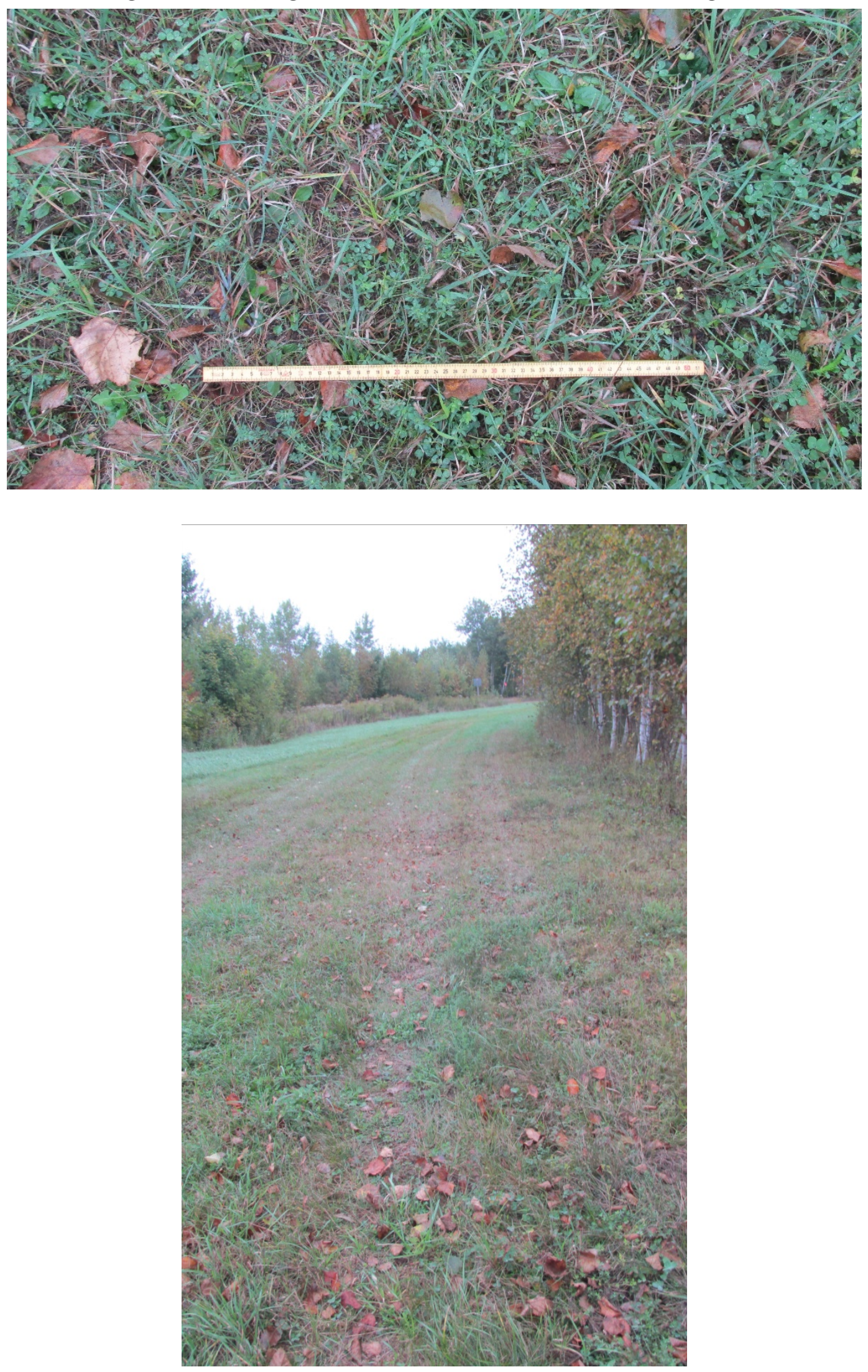
Figure B-4. Gravel pad (points 20GPVS and 21GPVS).
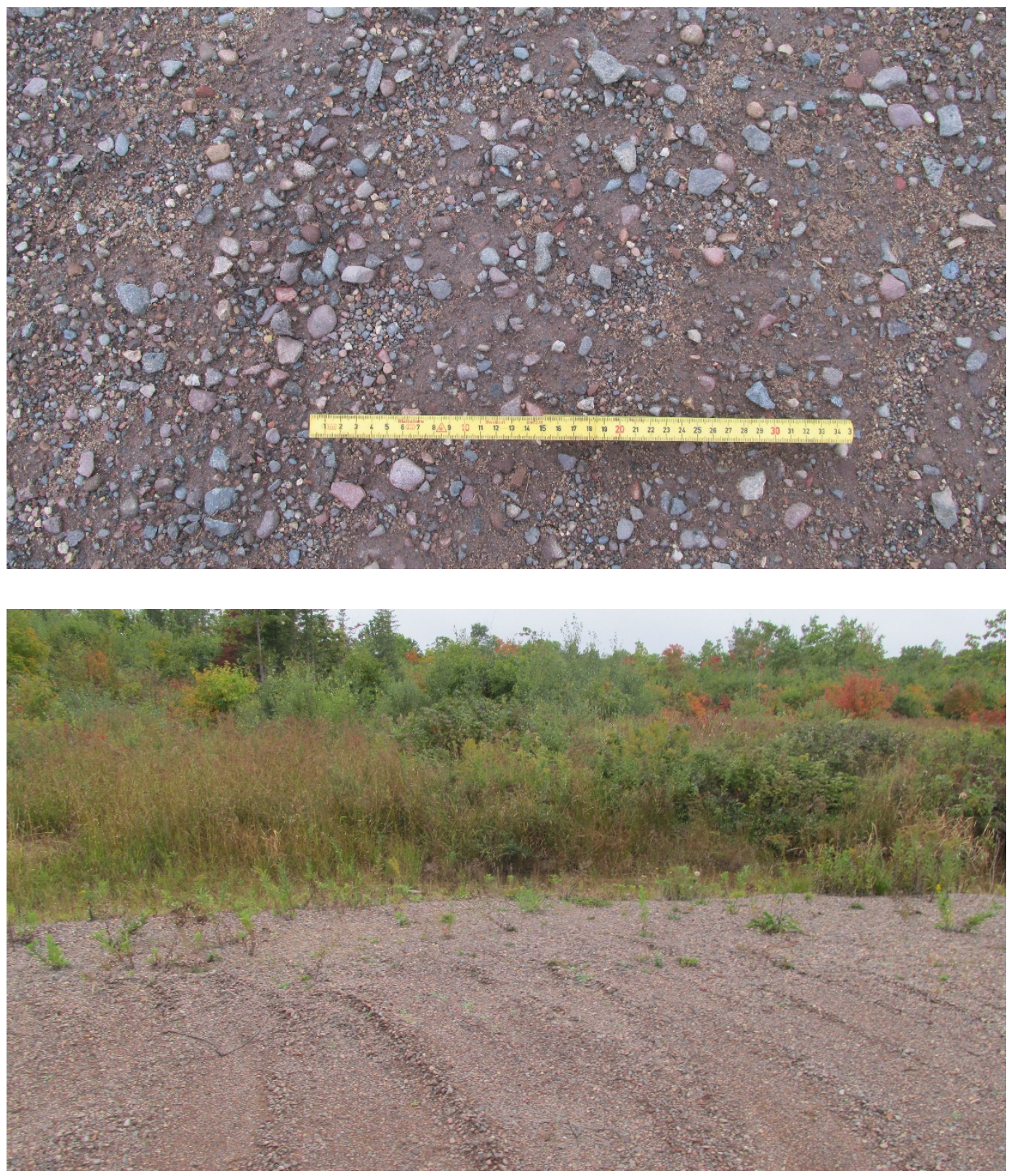
Figure B-5. Sweeper parking pad (points 21SPW_1 through 3).
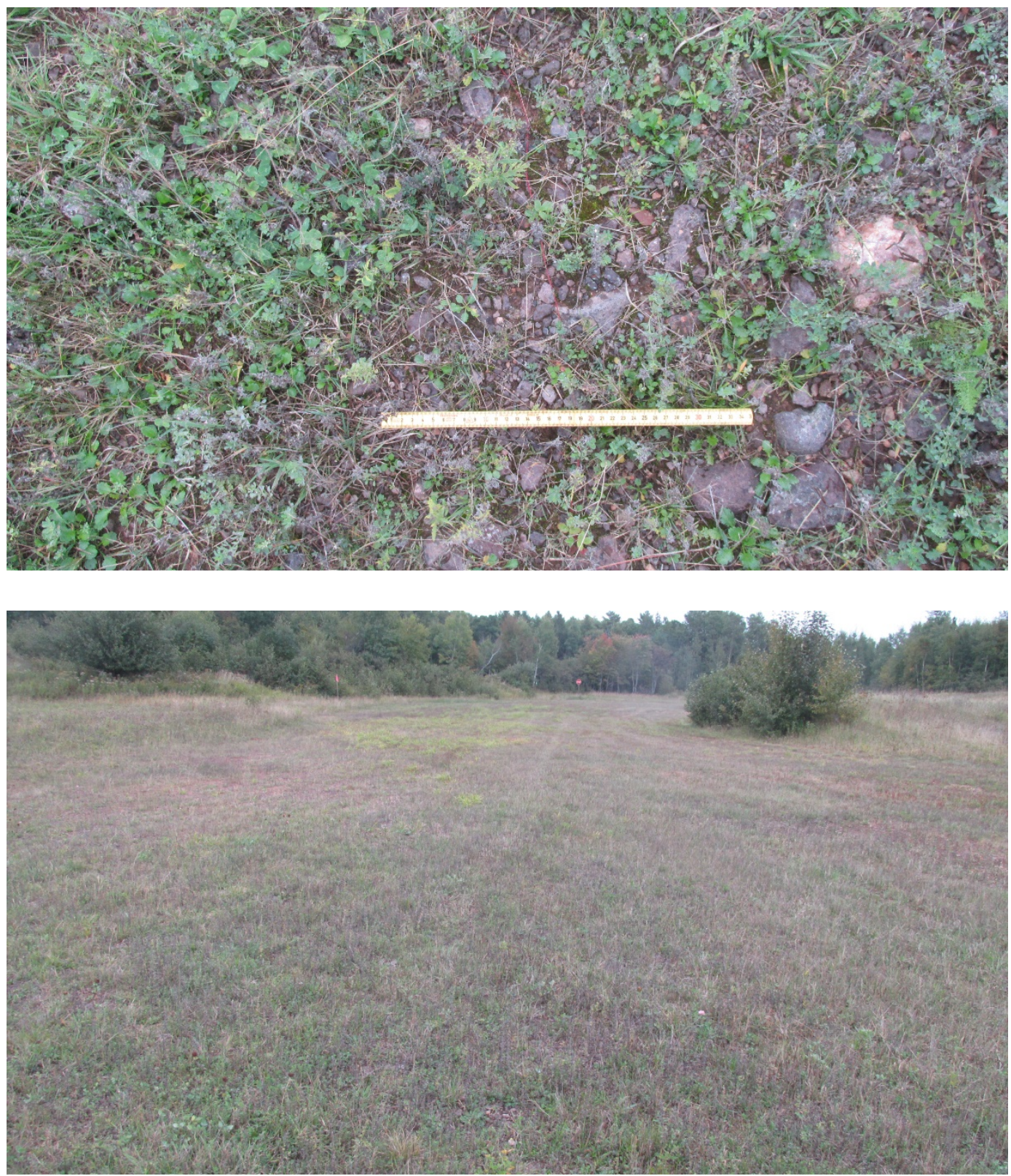
Figure B-6. Ice slope: entire slope (top), steep slope area (middle) (point 21IS_S), and lower slope area (bottom) (point 21IS_L).
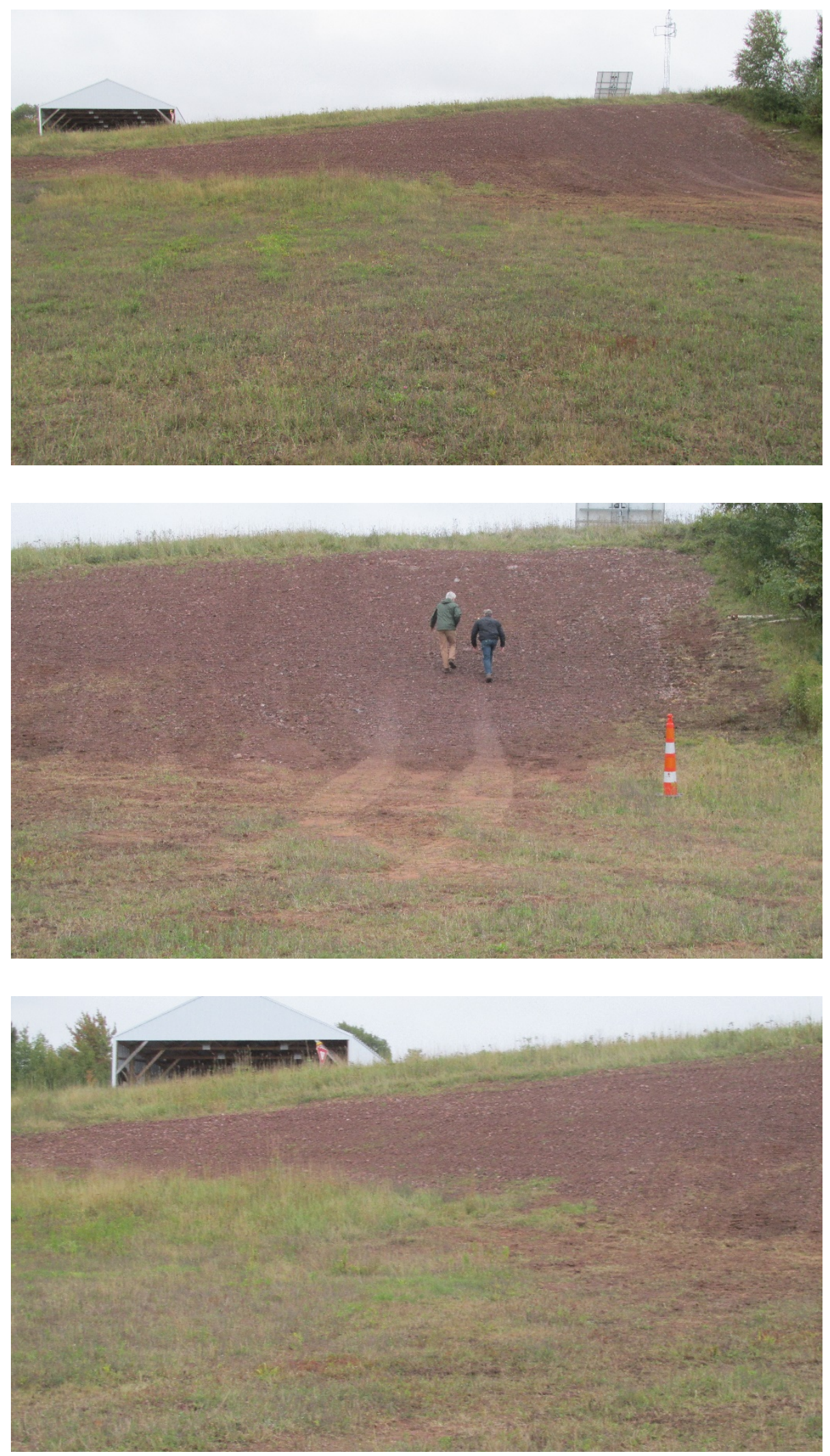
Figure B-7. Spin Up Pad 1 (points 21SU1_1 and 2).
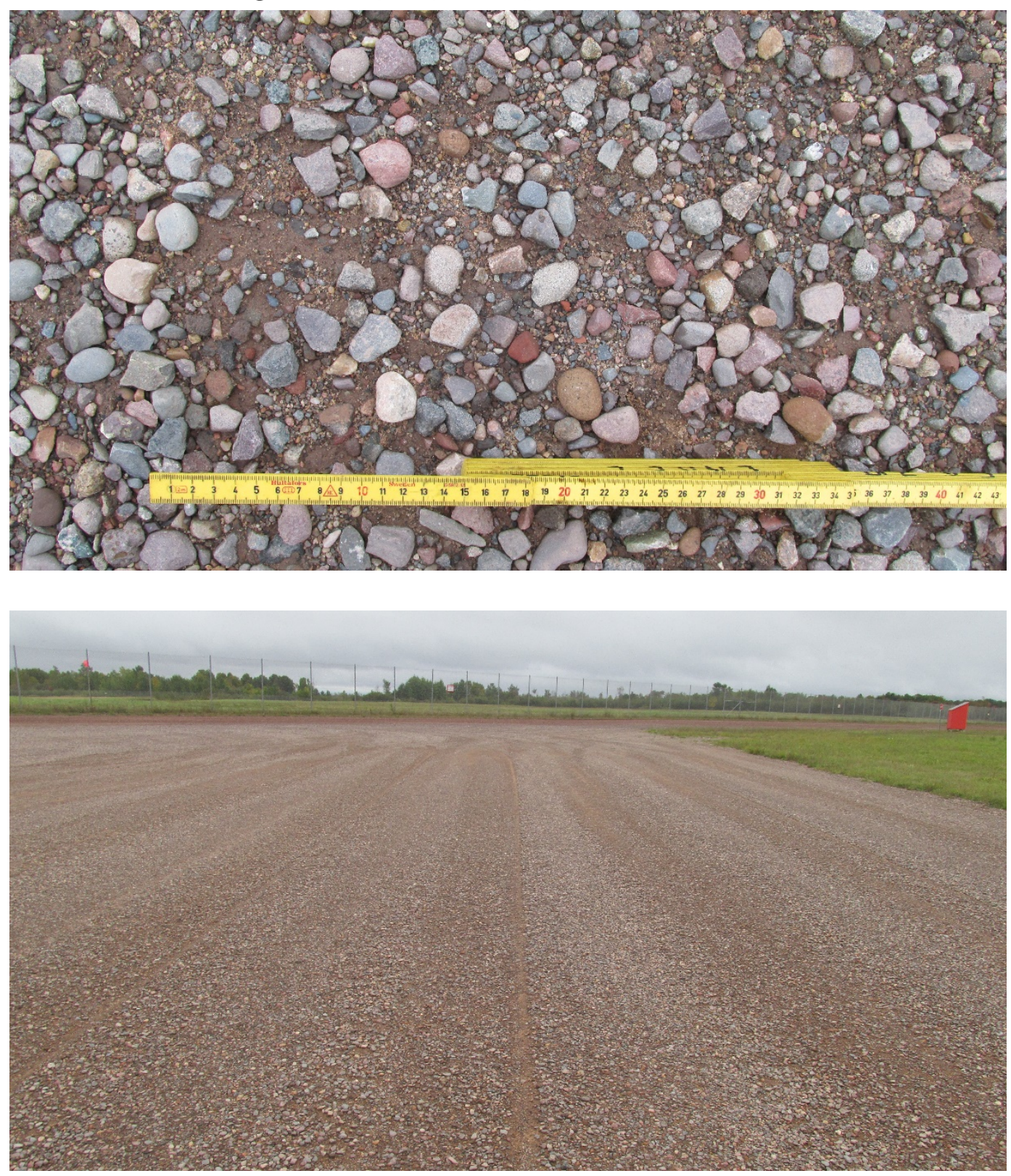
Figure B-8. Gravel road adjacent to the gravel pad, part of Loop 1 (point 22GPRD_1 and 2).
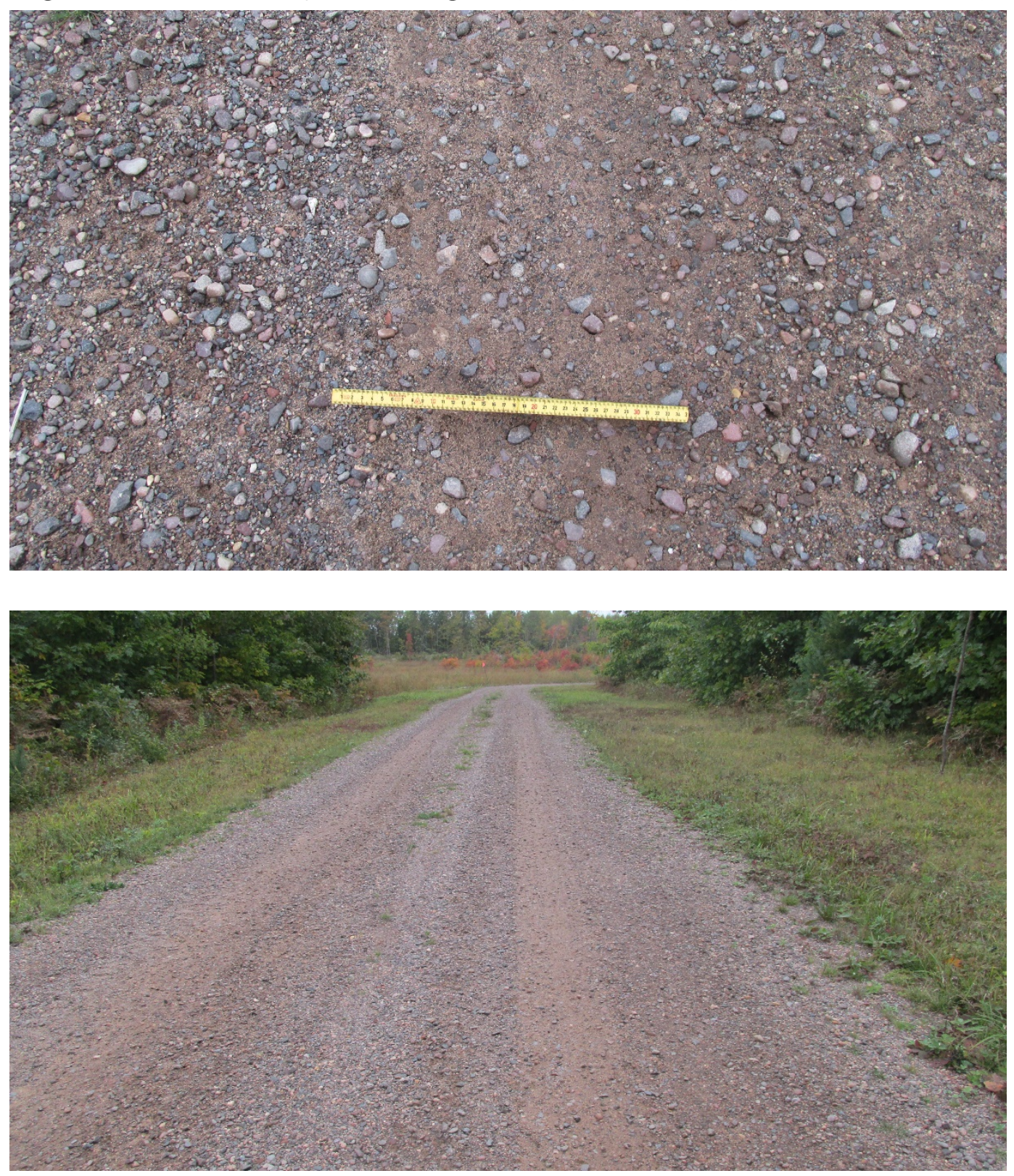
Figure B-9. Spin Up Pad 3 (points SU3_1 through 3).
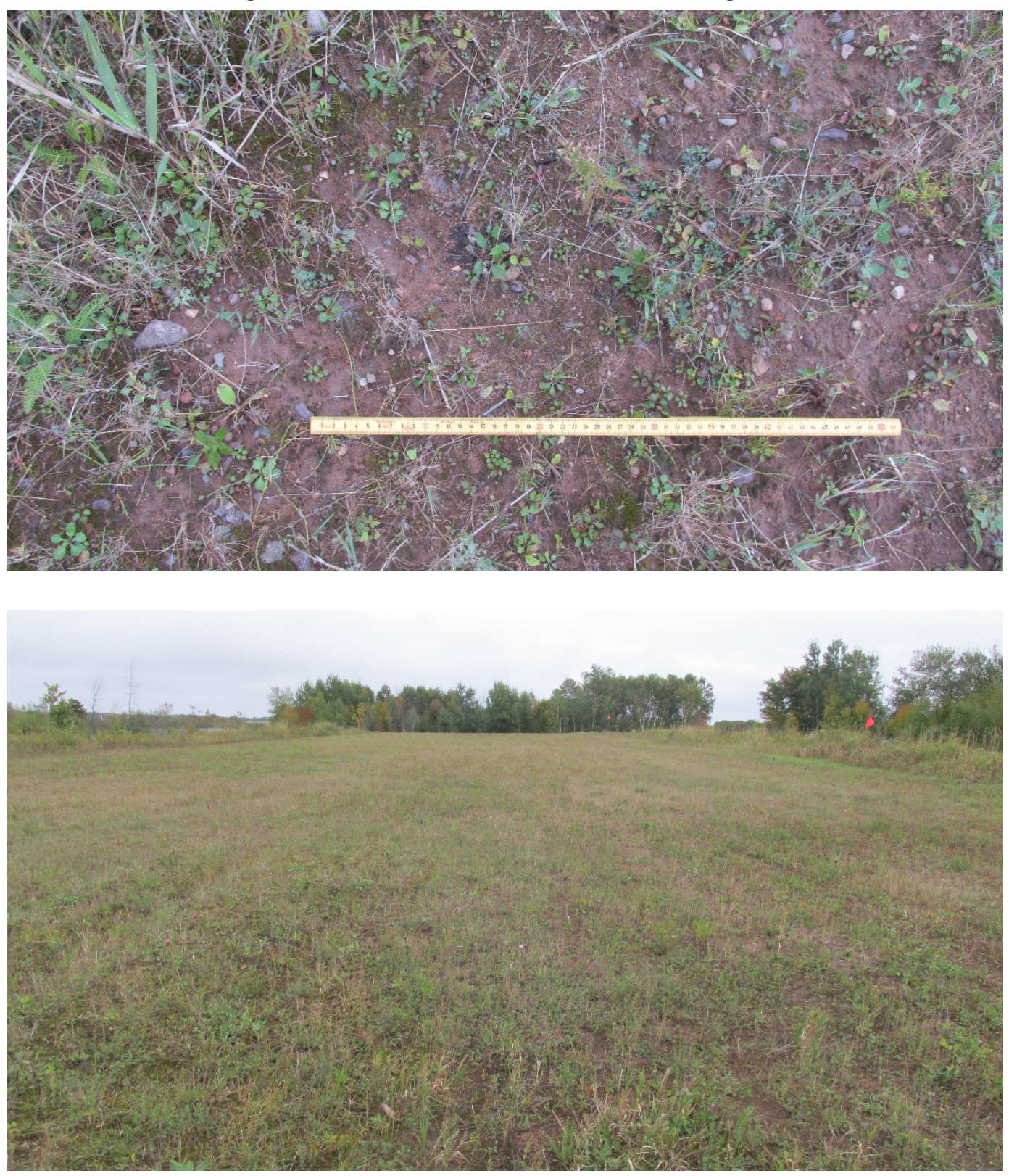
Figure B-10. Terrain north of Spin Up Pad 3 (points 22SU3VS_1 through 6).

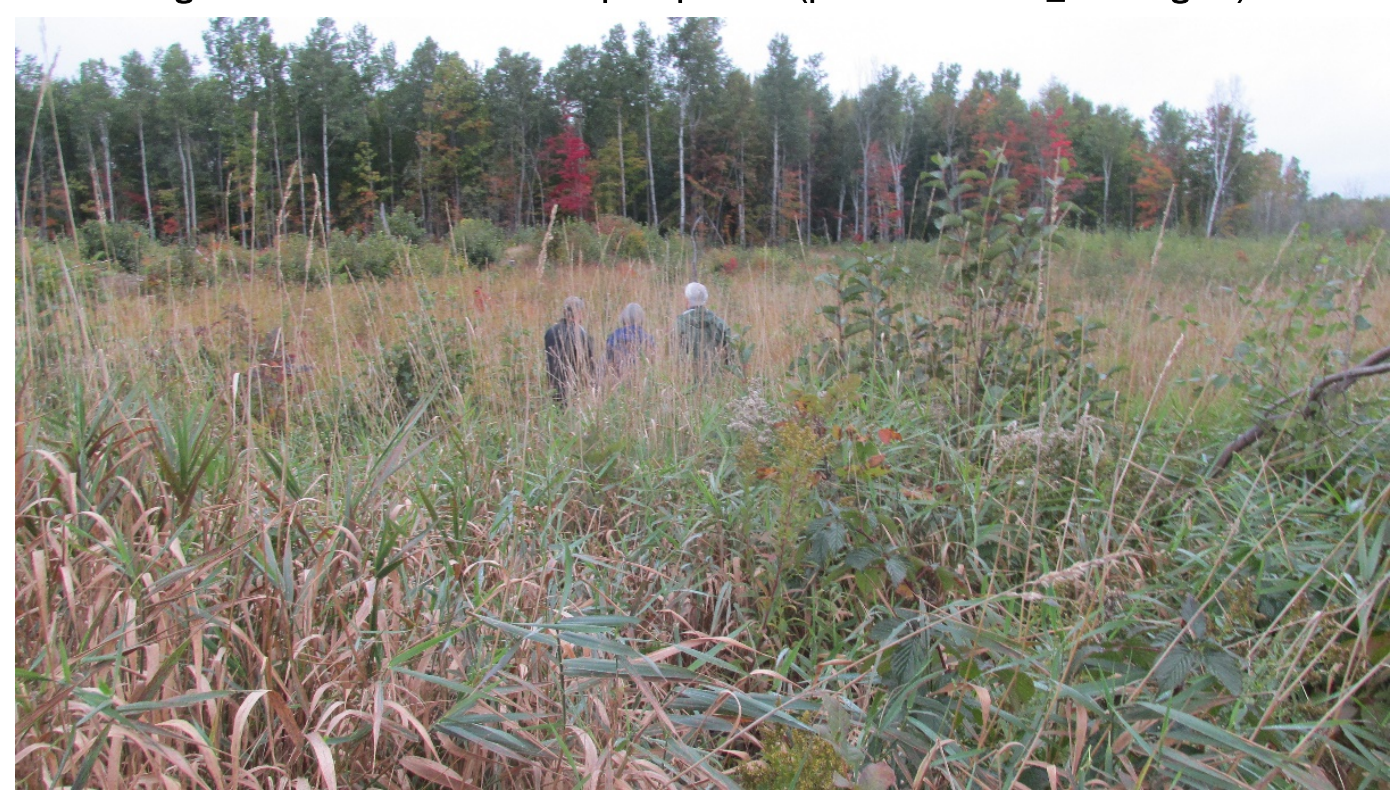


Figure B-11. Ice Rink area (points 22IR_S and 22IR_I).
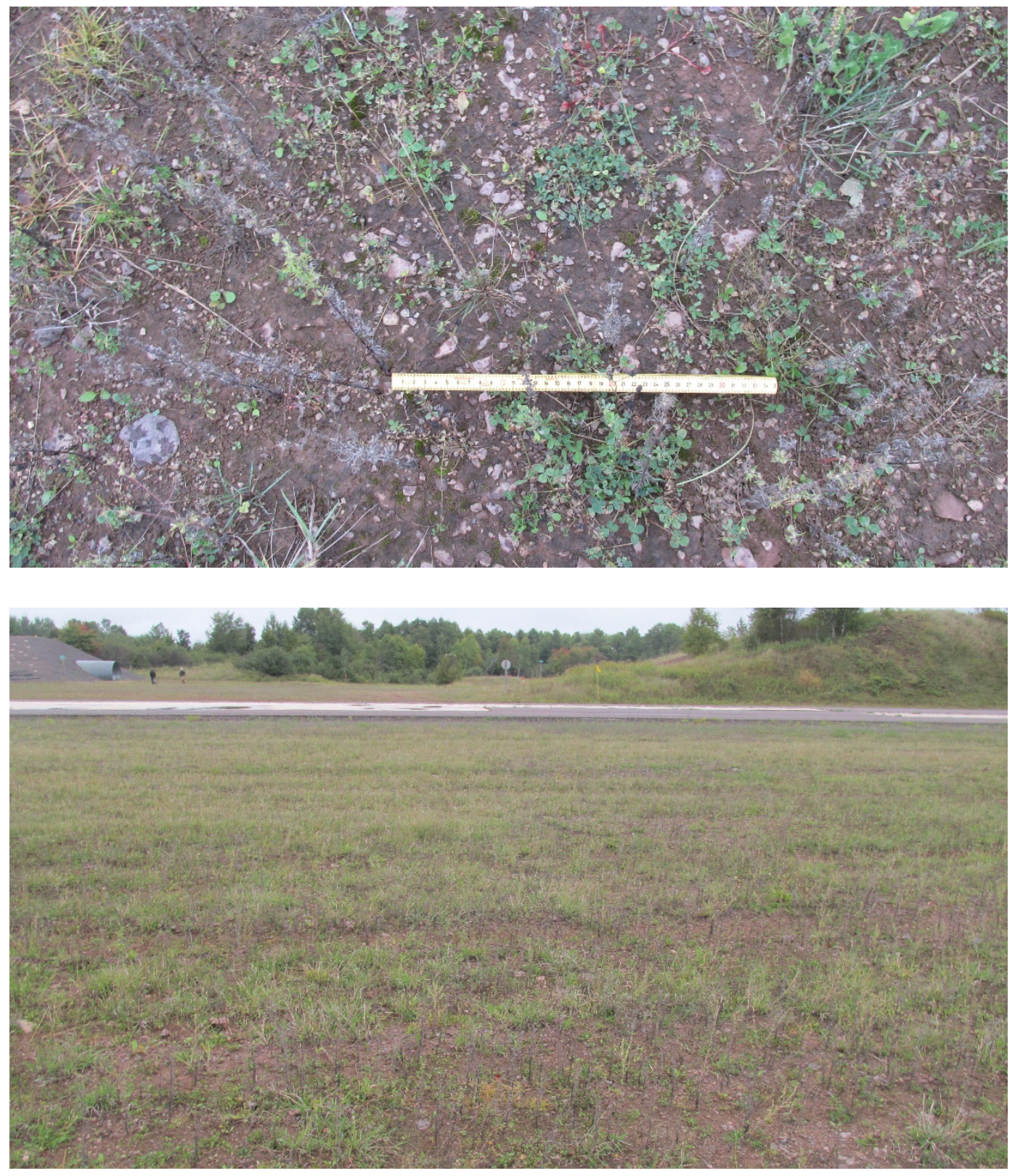
Figure B-12. Stability Test Area (points 22STAB_S and 22SATB_GI).
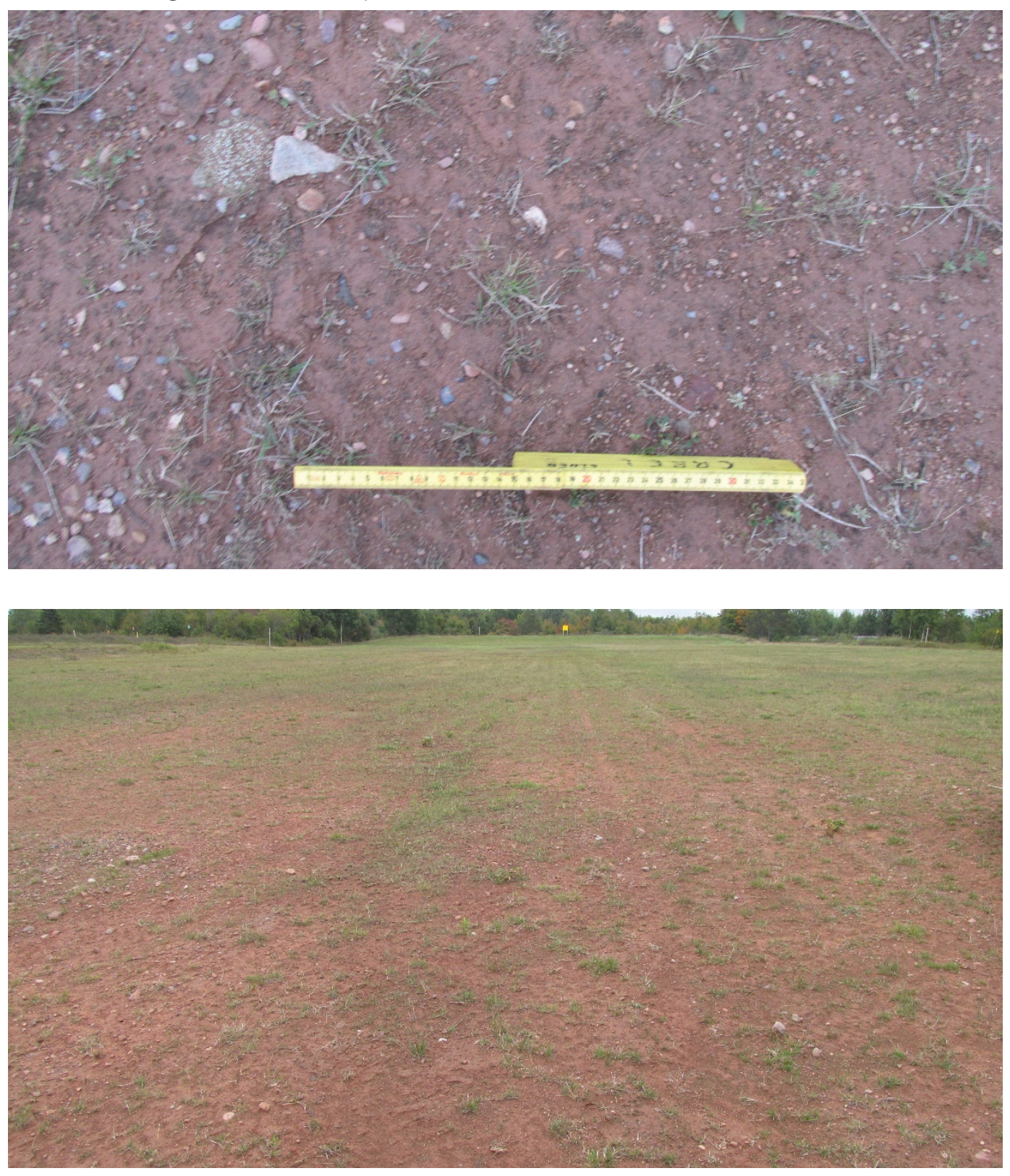
Figure B-13. Vehicle Dynamics Area 2 (points 22VDA2_1 and 2).
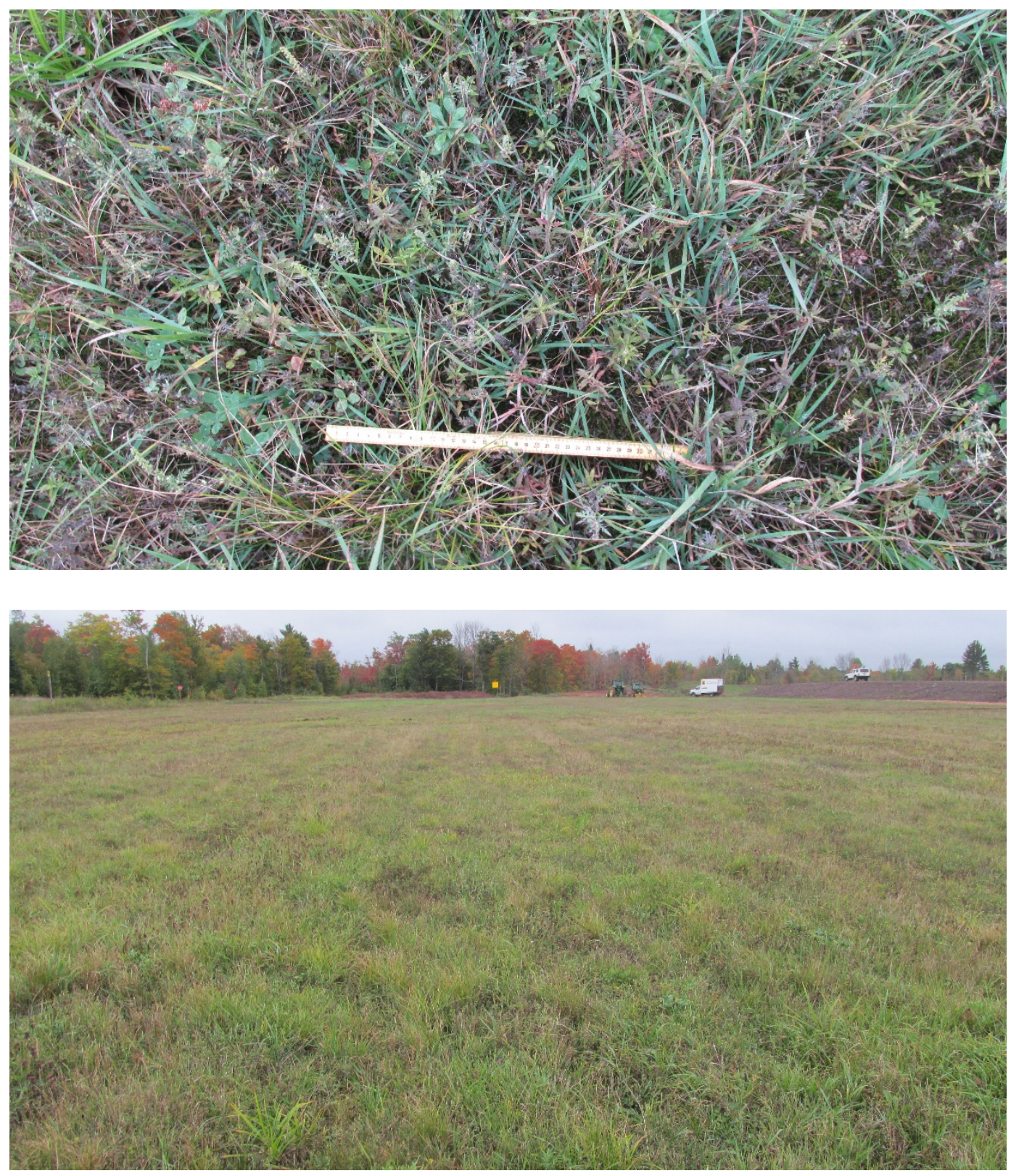
Figure B-14. Loop 4 (point 22LP4).
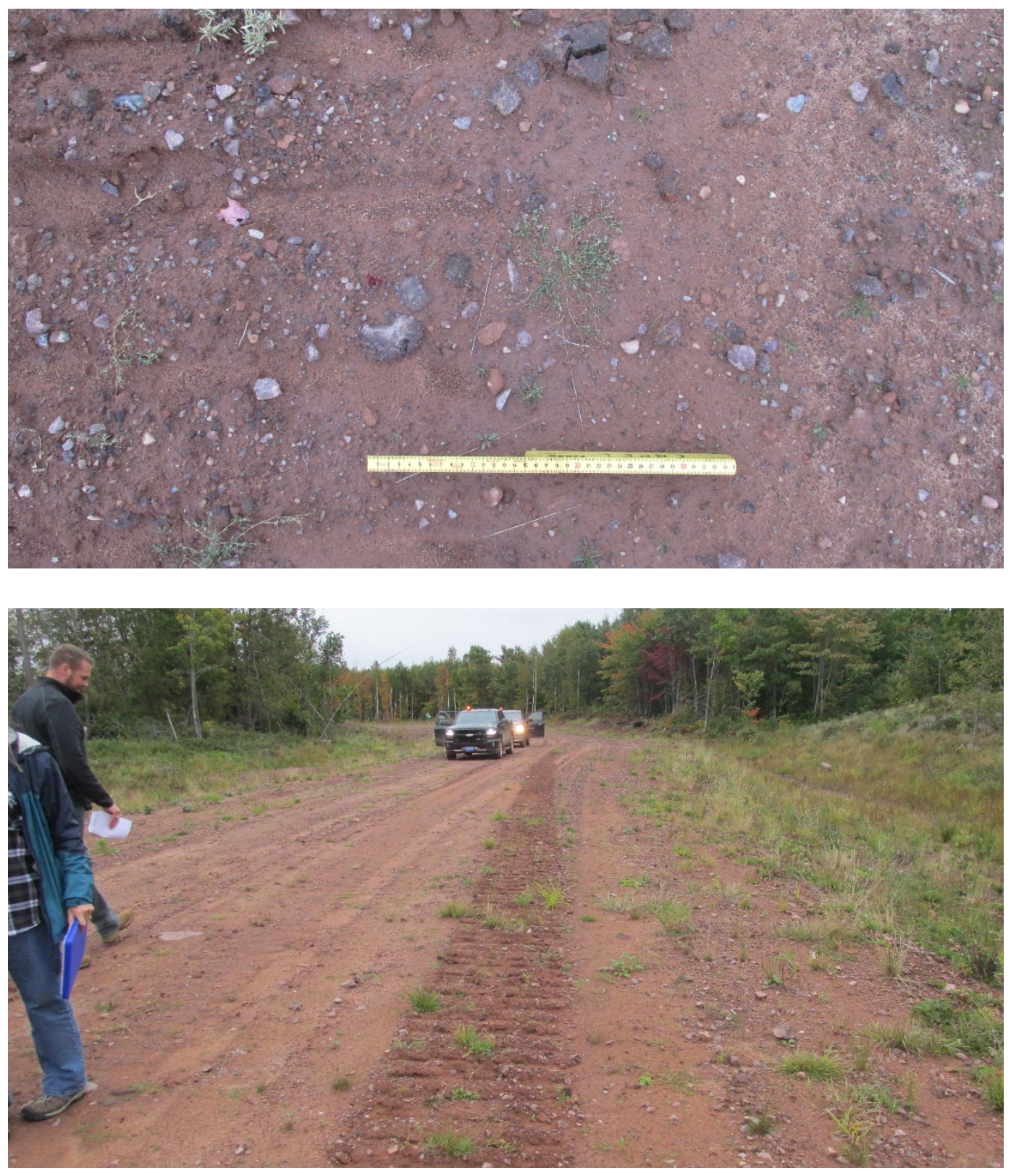
Figure B-15. Terrain off Loop 4 (point 22LP4VS).

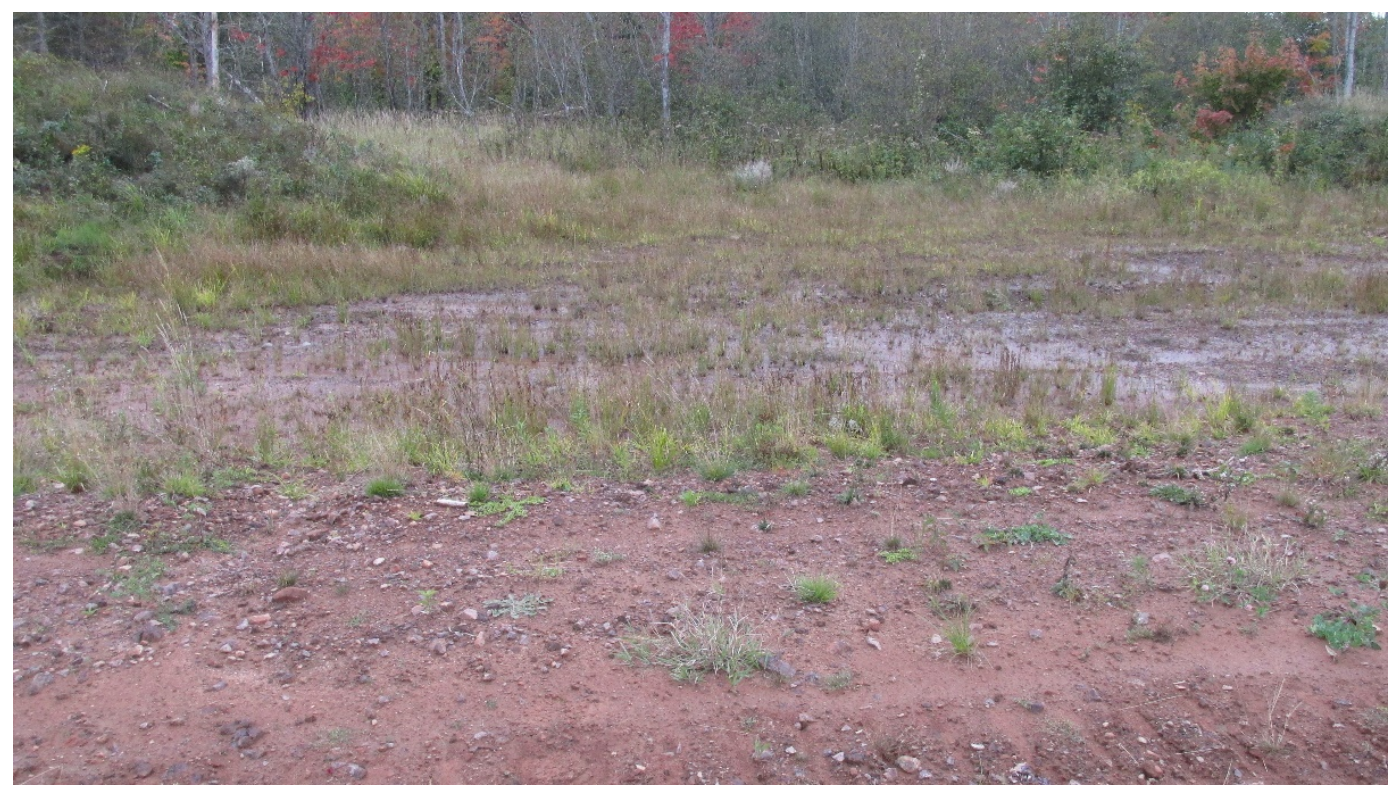




\section{Appendix C: Snow Pit and Weather Data}

Figures $\mathrm{C}-1$ through $\mathrm{C}-15$ show plots of snow densities, snow and air temperatures, and snow moisture. The data are from the snow pits prepared at both the Montana and Michigan sites. Section 3 details the procedures for these measurements. Snow density measurements for these figures were made by both direct volume sampling (in green and labeled "Pit") and with the Finnish fork (in blue and labeled "Fork"). The black dotted line in the plots represents the calculated average between these measurements, with a shaded area in between. Temperature measurements were made with a handheld type-T thermocouple. Dashed lines and the shaded area (pink) represent a \pm 1.0 degree standard error (typical for a type- $T$ thermocouple). Black diamonds shows air temperature as measured $15 \mathrm{~cm}$ (6 in.) above the ground using the thermocouple. Snow moisture measurements were made using one or two Denoth meters. In cases where two Denoth meters were used, the results were averaged and are shown as a black dotted line with a shaded area in between. In cases where only one meter was used, those data are plotted with a standard $\pm 0.3 \%$ vol error (shaded area). For any depths where a measurement was missing, data were linearly interpolated.

Figures $\mathrm{C}-16$ through $\mathrm{C}-29$ provide the meteorological data (temperature, humidity, and wind) for each day as recorded during the Montana and Michigan field campaigns by the local Automated Weather Stations (AWS). The Montana AWS is located at the West Yellowstone Airport itself, where NATC operates. The Michigan AWS is located at the Houghton County Airpark, $9.5 \mathrm{~km}$ (6 miles) south of Calumet, Michigan, which is adjacent to KRC. All data are shown with a second-order locally weighted smoothing (black line with bin-width of 15 minutes). 
Figure C-1. Snow-pit density, temperature, and snow moisture profiles for the two snow pits at Montana test point 27RWYS, 27 January 2018.

27-JAN-HMMWV - VIRGIN SNOW 1

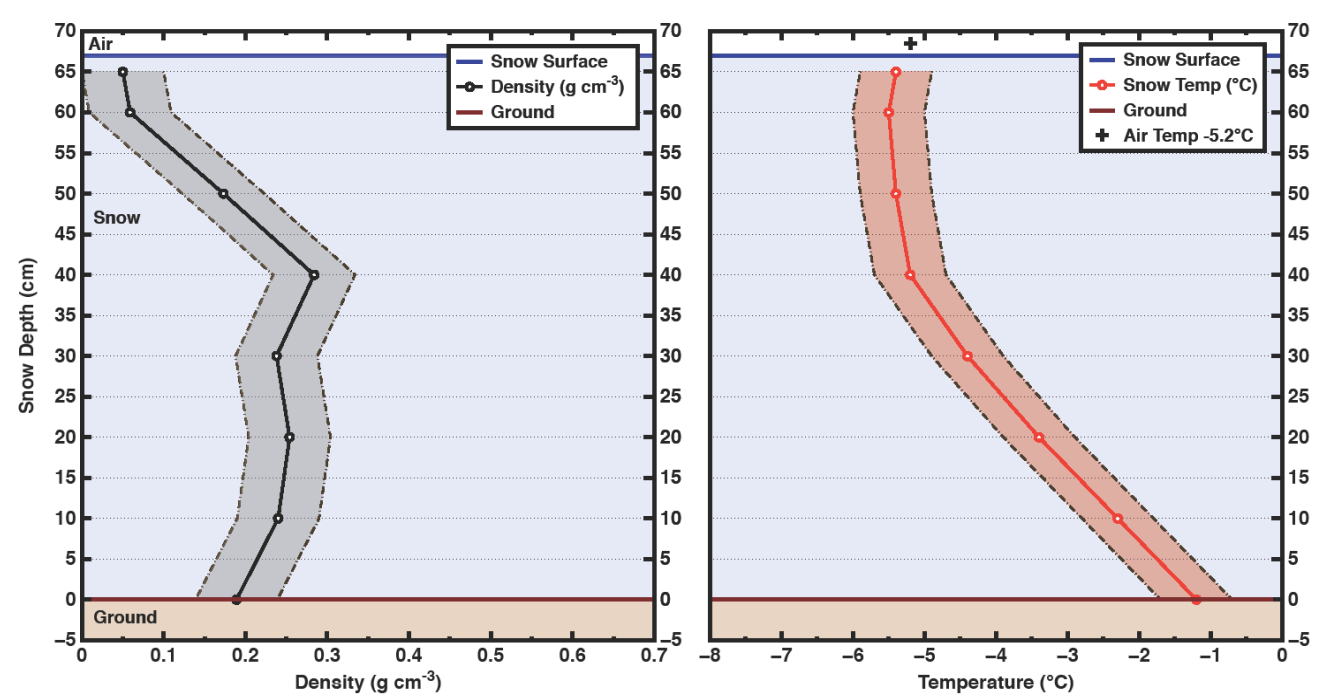

27-JAN-HMMWV - VIRGIN SNOW 2 - 18:30

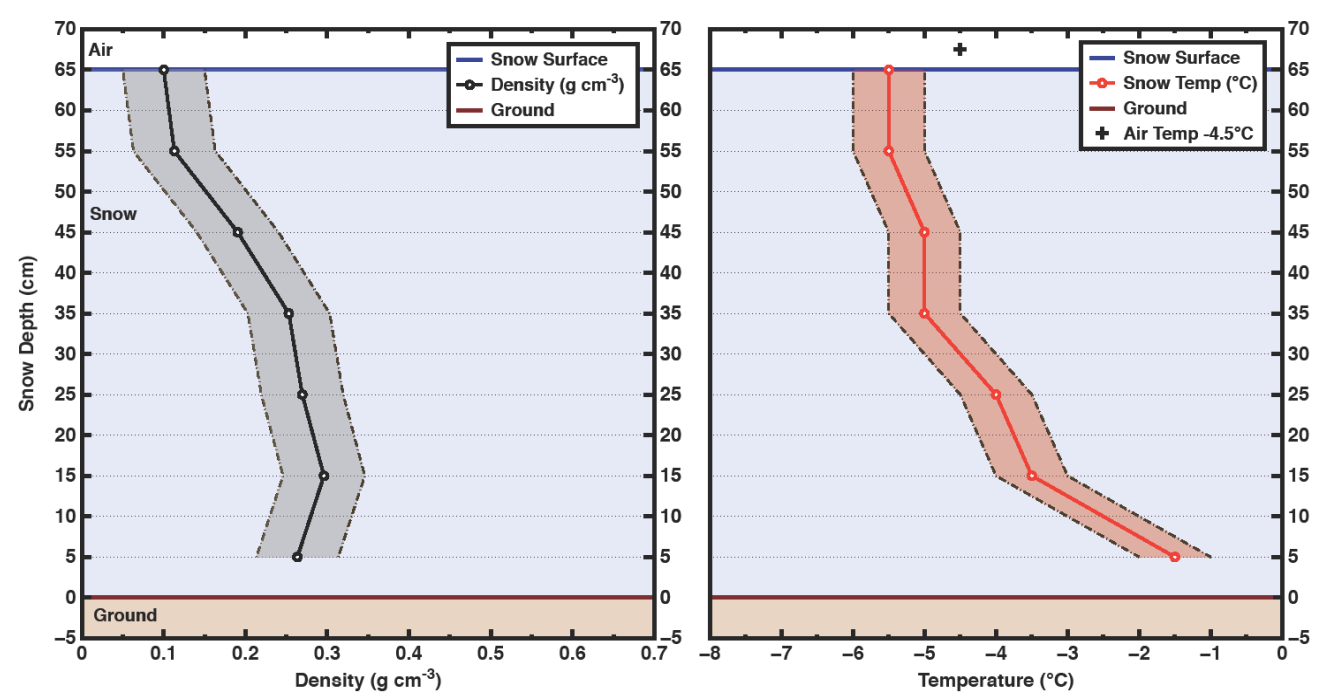


Figure C-2. Snow-pit density, temperature, and snow moisture profiles for the snow pit at Montana test point 27TWYS, 27 January 2018.

27-JAN-MRZR - Coast Down - VIRGIN SNOW - 19:00
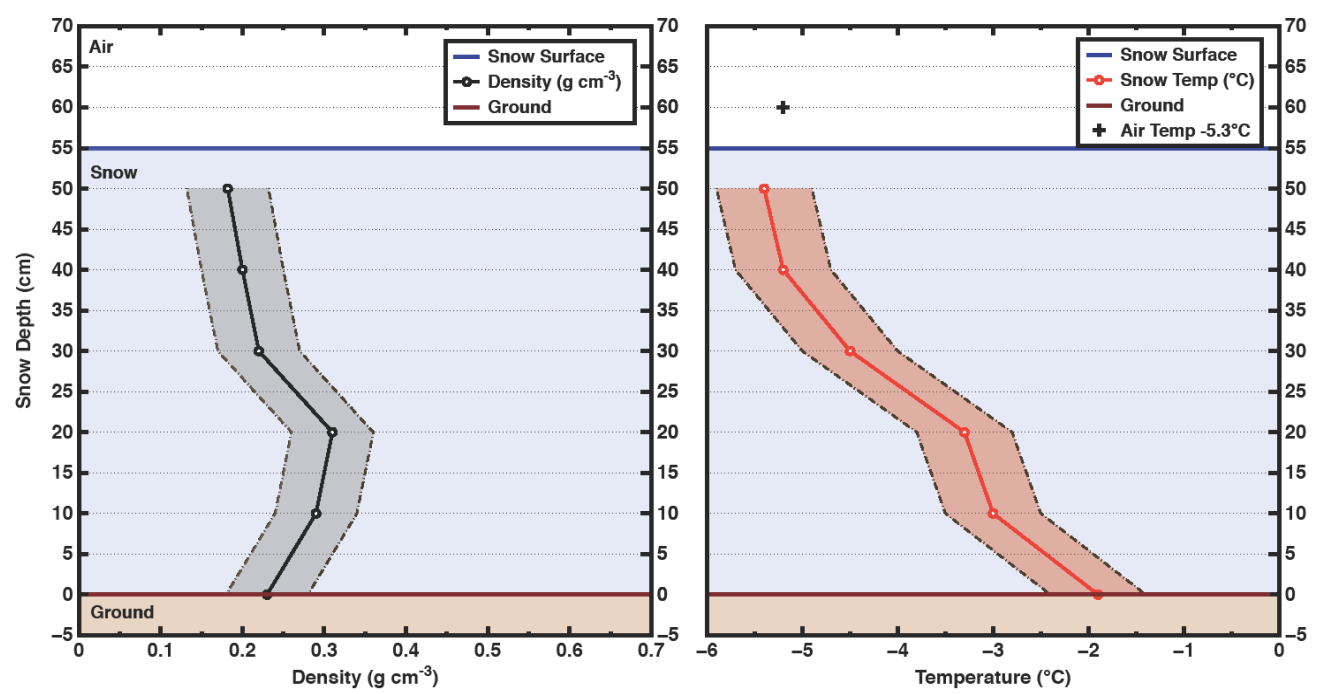

Figure C-3. Snow-pit density, temperature, and snow moisture profiles for the snow pit at Montana test point 28MLPW, 28 January 2018.

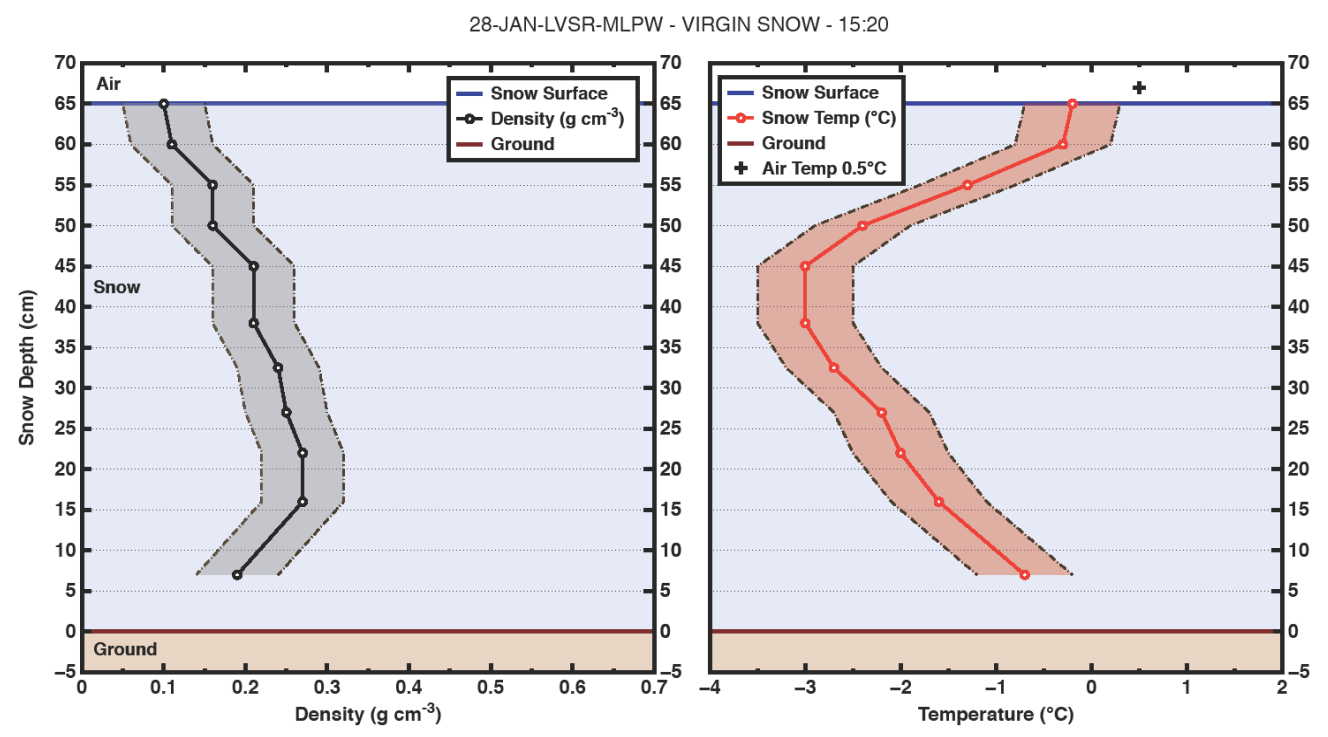


Figure C-4. Snow-pit density, temperature, and snow moisture profiles for the snow pit at Montana test point 27TWYS, 29 January 2018.

29-JAN-LVSR-Coast Down Test - VIRGIN SNOW - 12:00
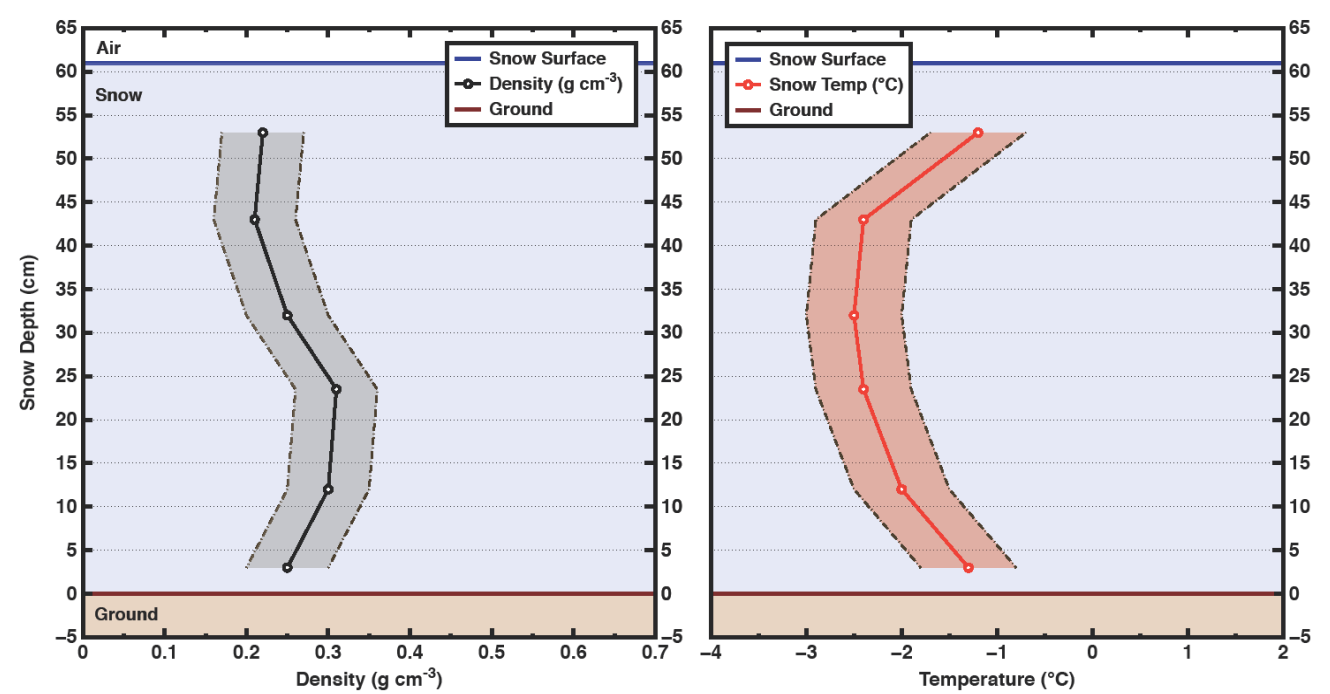

Figure C-5. Snow-pit density, temperature, and snow moisture profiles for the snow pit at Montana test point 27RWYS, 29 January 2018.

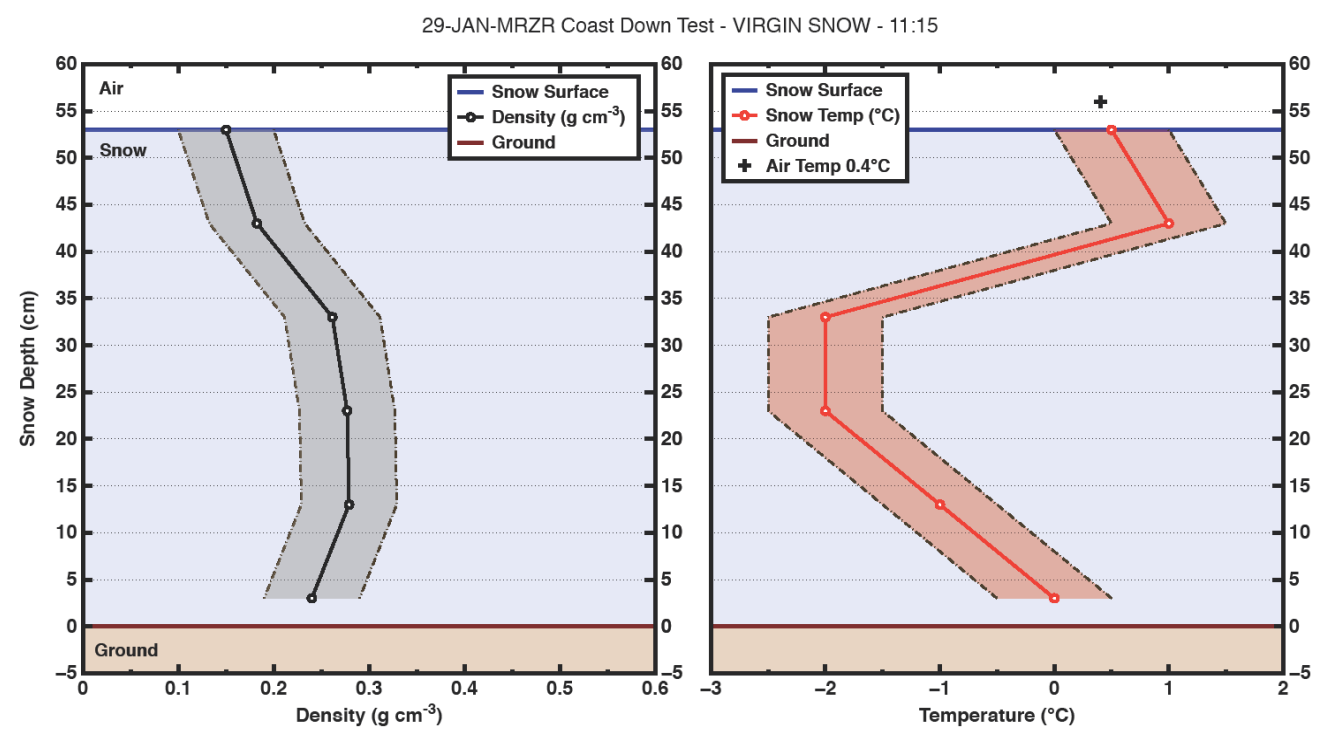


Figure C-6. Snow-pit density, temperature, and snow moisture profiles for the snow pit at Montana test point 27RWYS, 30 January 2018.

30-JAN-MTVR - COAST DOWN TEST - VIRGIN SNOW - 12:20
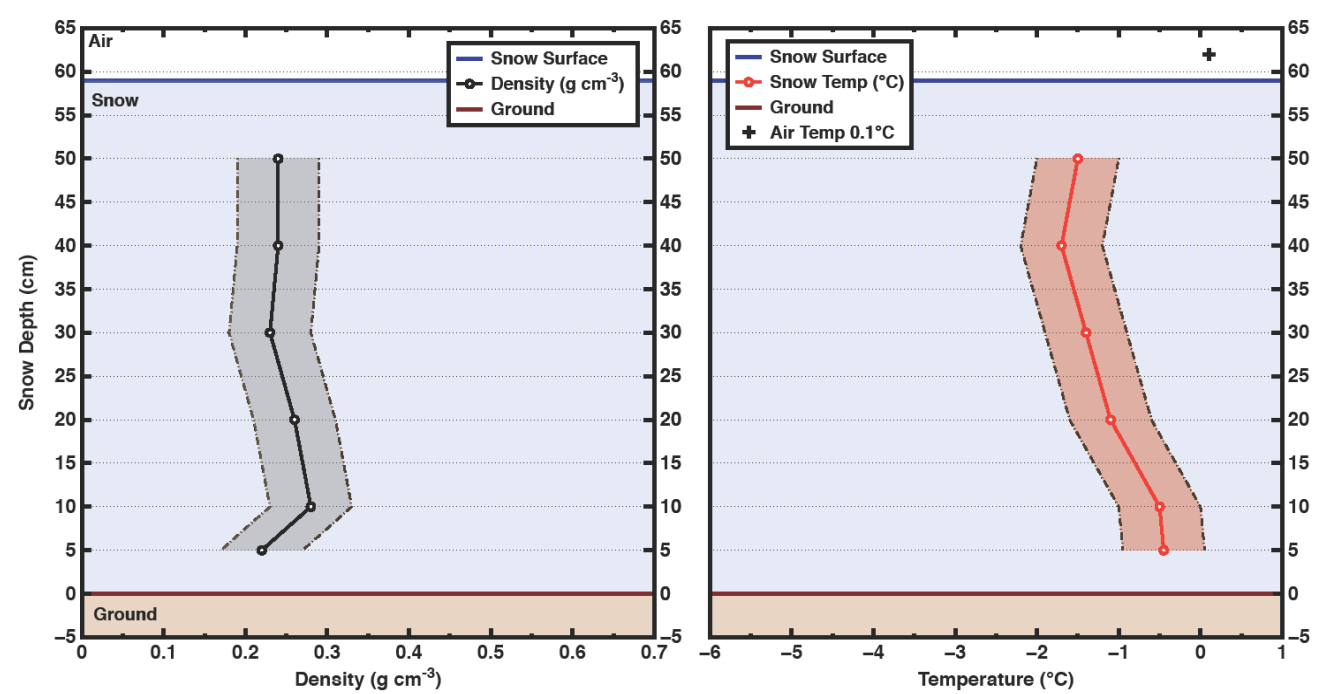

Figure C-7. Snow-pit density, temperature, and snow moisture profiles for the snow pit at Montana test point 30MLPN, 30 January 2018.

30-JAN-MTVR - MOBILITY LOOP TEST - VIRGIN SNOW - 07:00
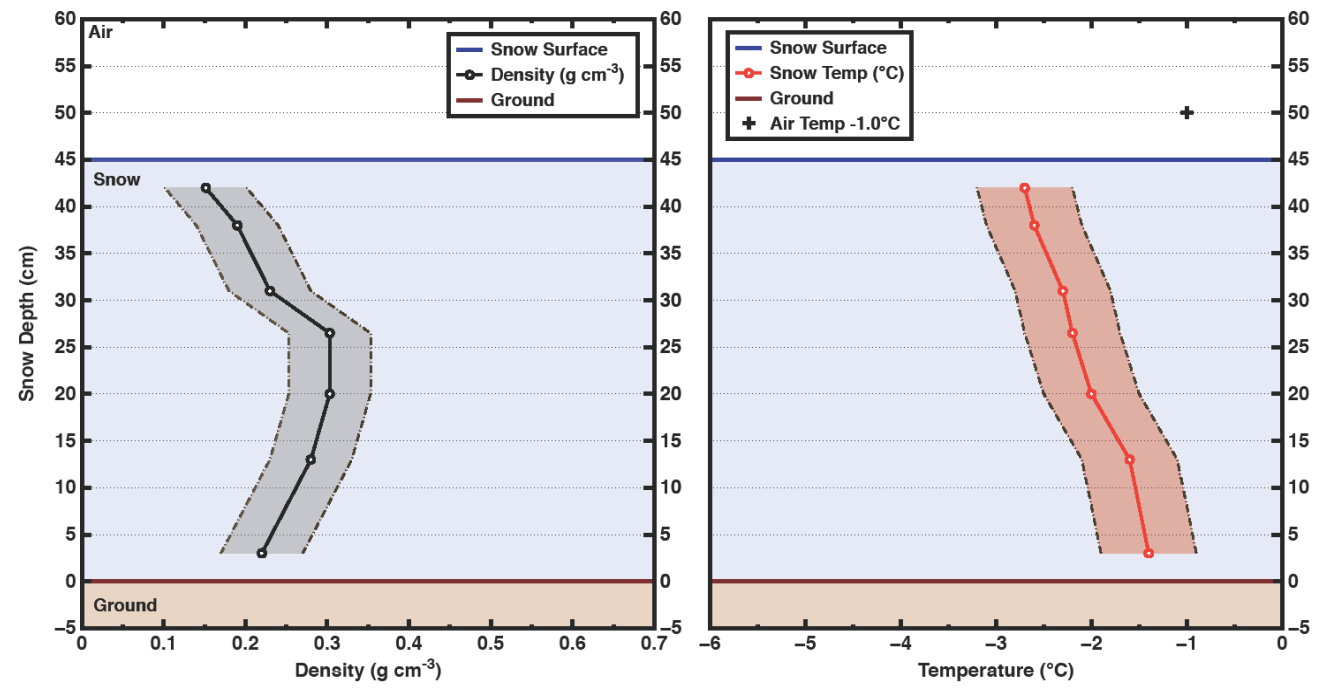
Figure C-8. Snow-pit density, temperature, and snow moisture profiles for the snow pit at Montana test point 27RWYS, 31 January 2018.

31-JAN-MTVR - COAST DOWN TEST - VIRGIN SNOW - 07:00

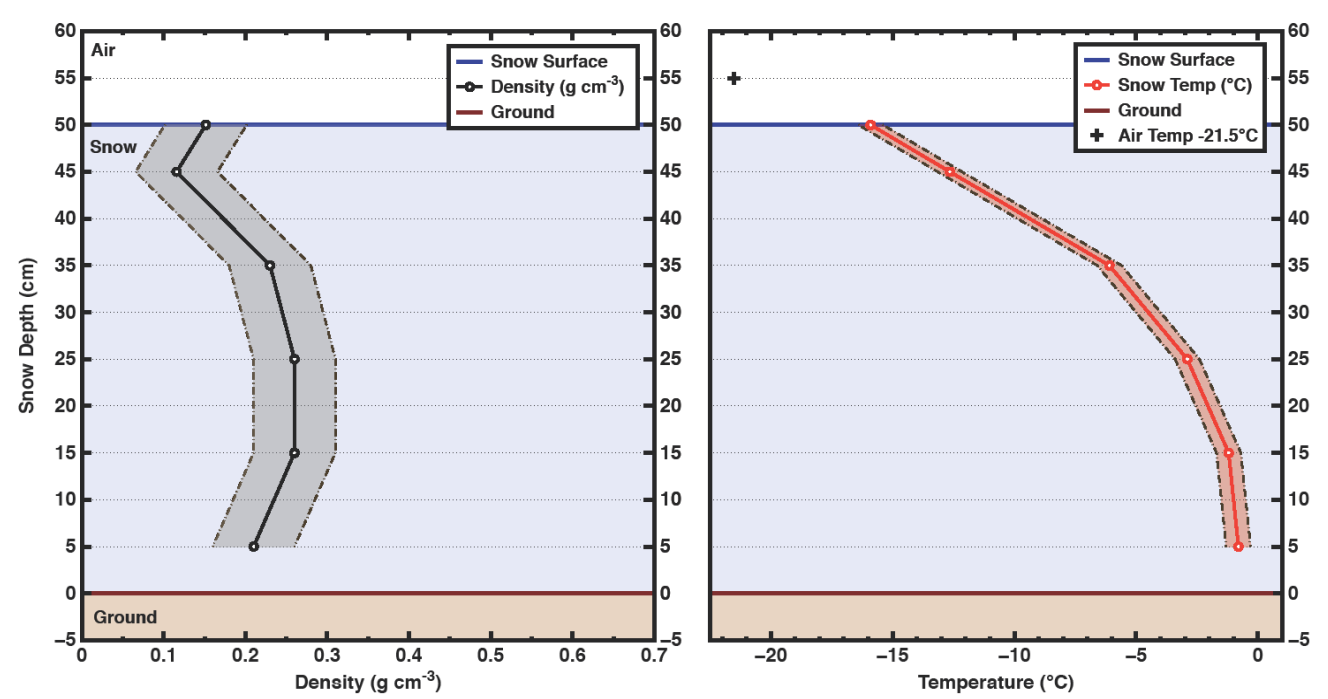

Figure C-9. Snow-pit density, temperature, and snow moisture profiles for the snow pit at Michigan test point 19SU2VS_A, 19 February 2018.
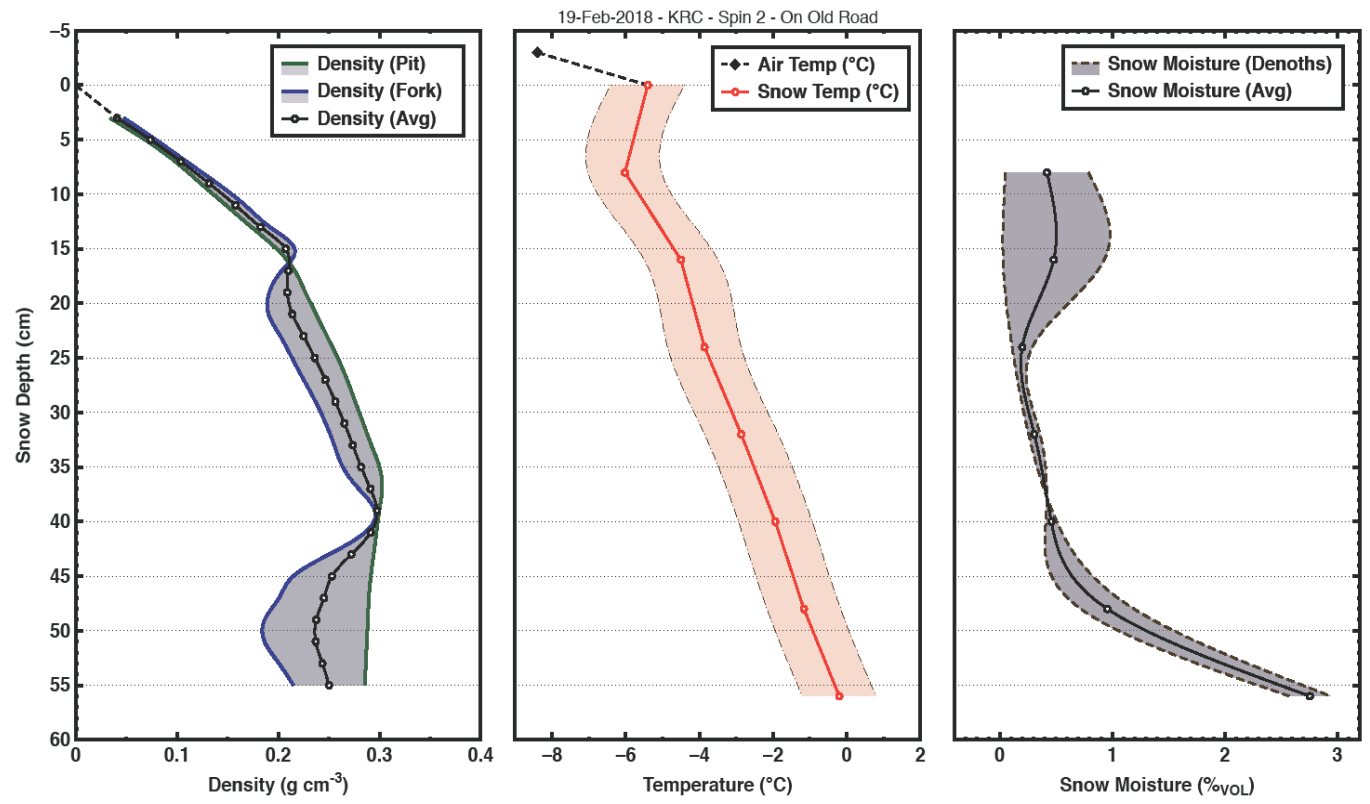
Figure C-10. Snow-pit density, temperature, and snow moisture profiles for the snow pit at Michigan test point 19SU2VS_E, 19 February 2018.
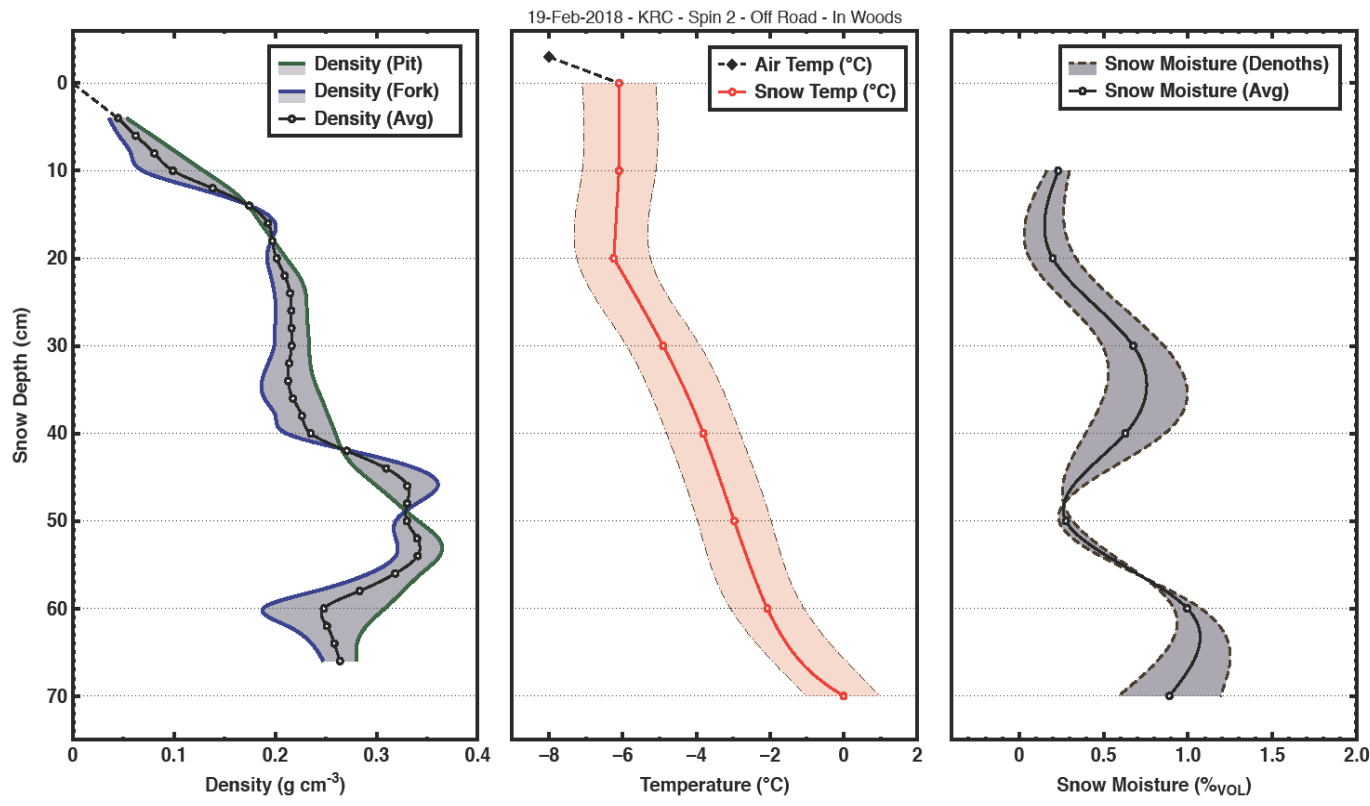

Figure C-11. Snow-pit density, temperature, and snow moisture profiles for the snow pit at Michigan test point 20GPVS, 20 February 2018.
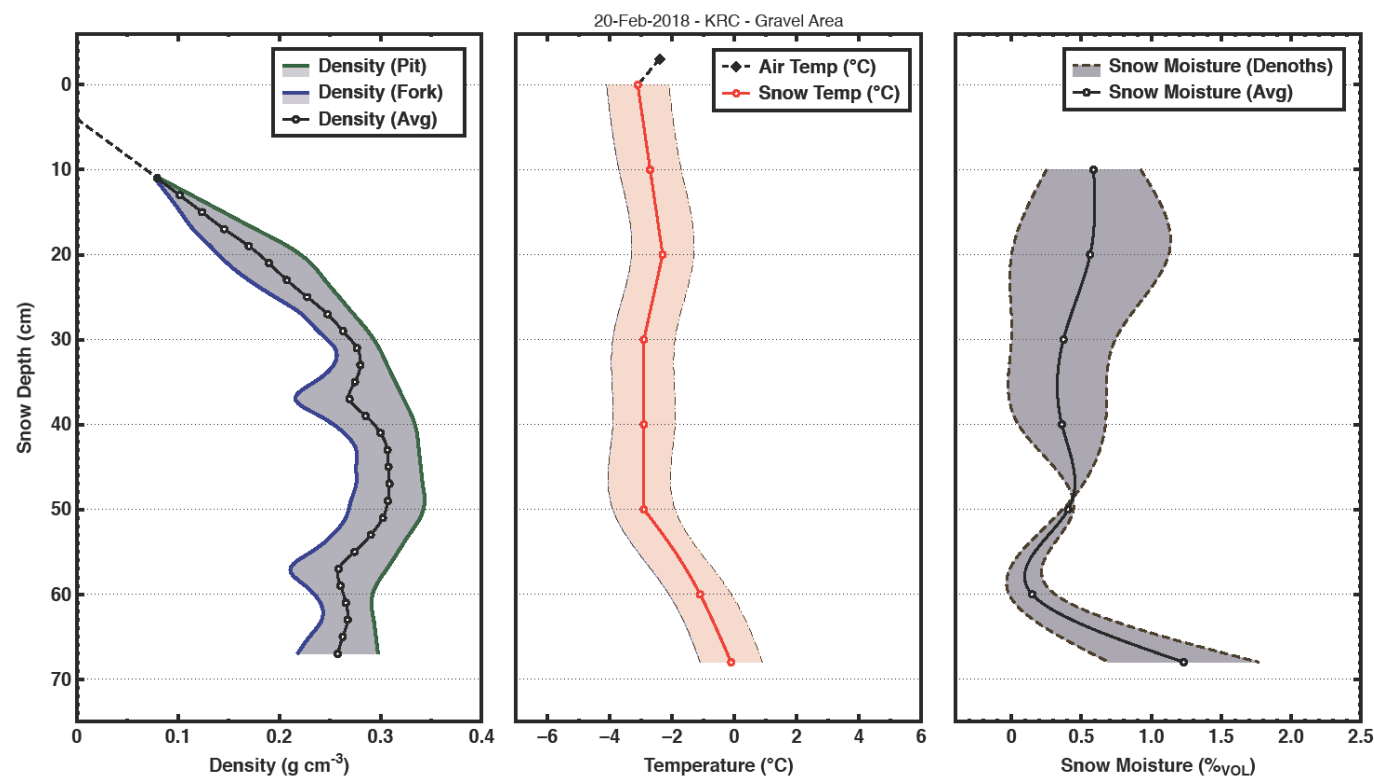
Figure C-12. Snow-pit density, temperature, and snow moisture profiles for the snow pit at Michigan test point 21IS_S, 21 February 2018.
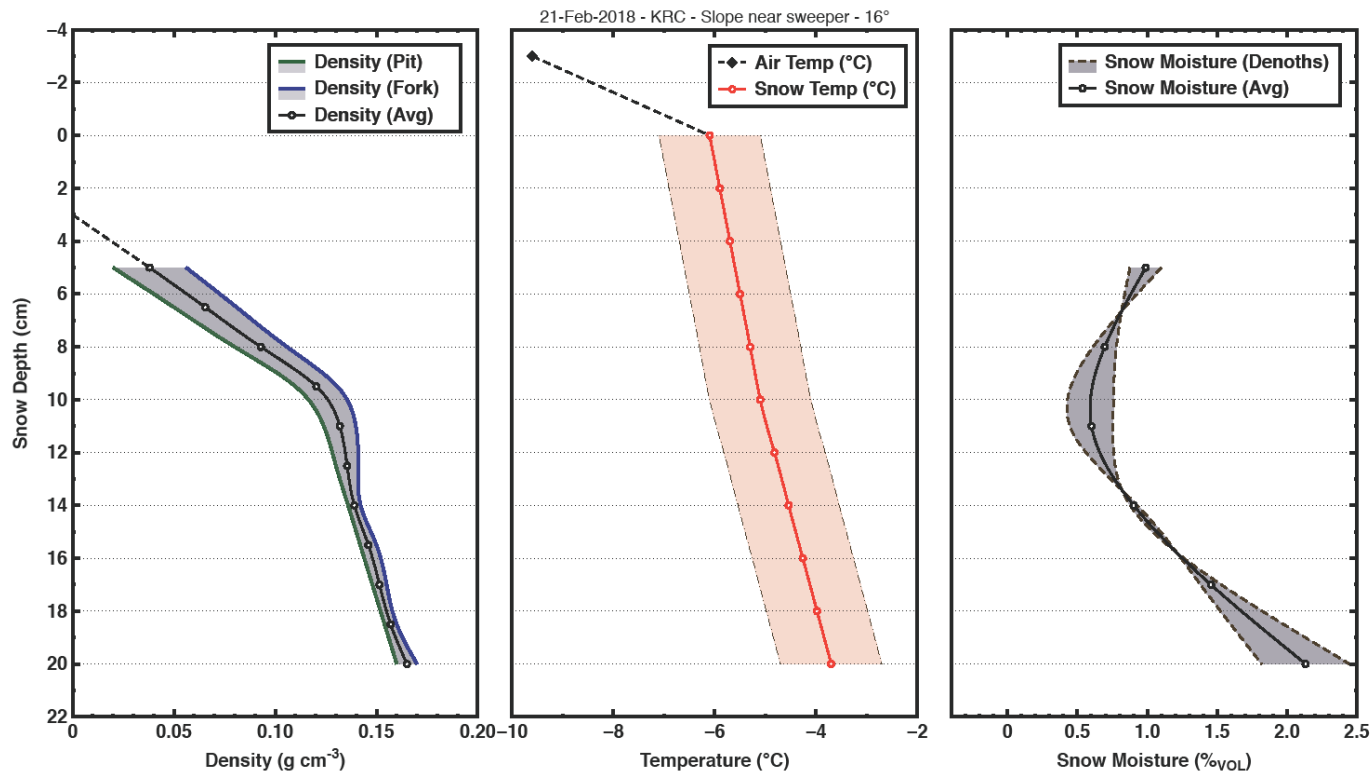

Figure C-13. Snow-pit density, temperature, and snow moisture profiles for the snow pit at Michigan test point 21IS_L, 21 February 2018.
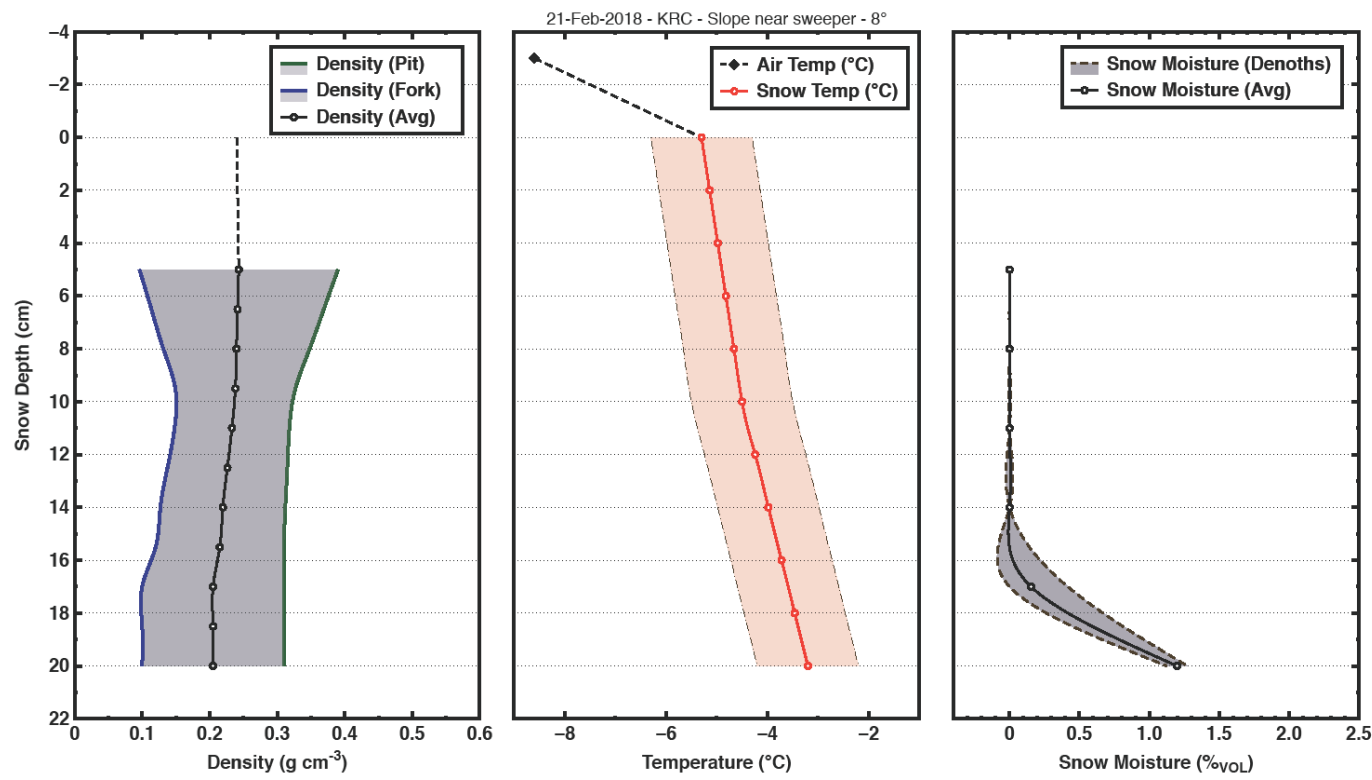
Figure C-14. Snow-pit density, temperature, and snow moisture profiles for the snow pit at Michigan test point 22SU3VS, 21 February 2018.
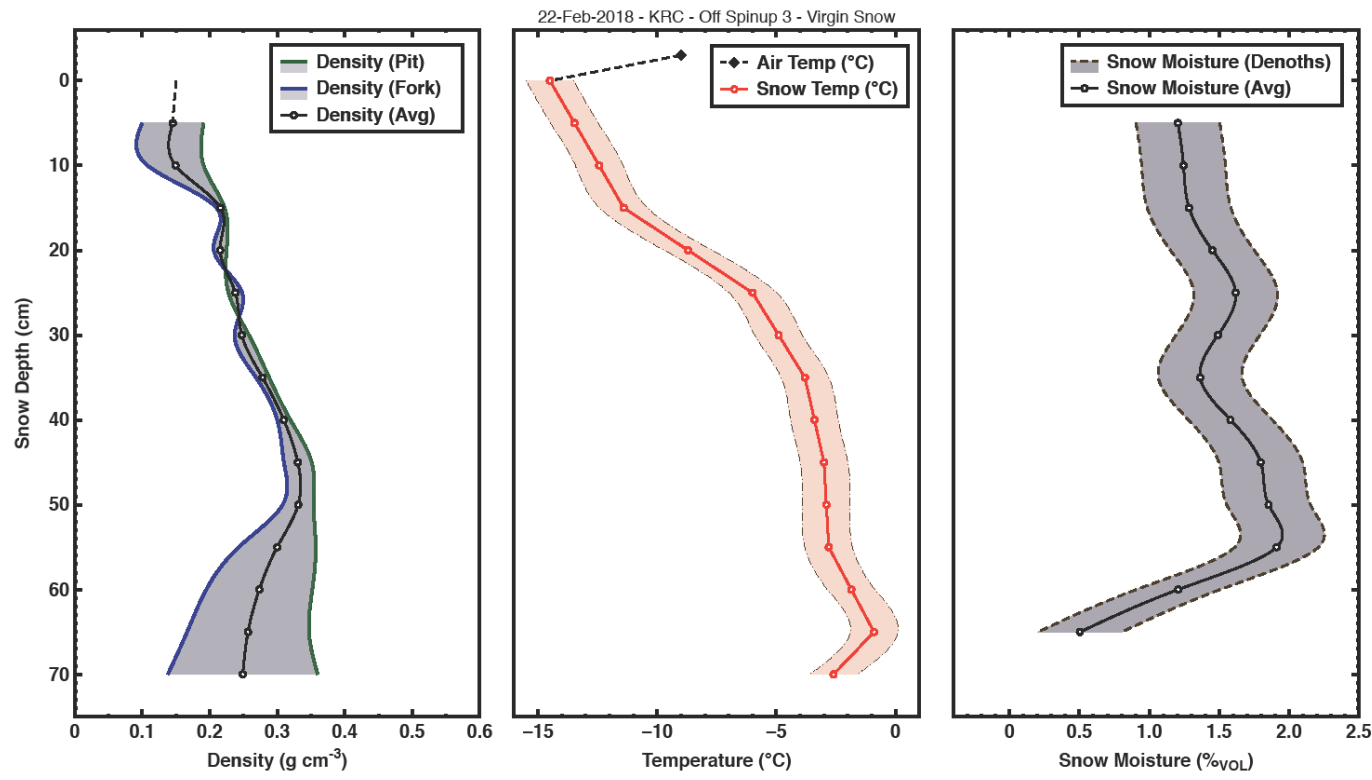

Figure C-15. Snow-pit density, temperature, and snow moisture profiles for the snow pit at Michigan test point 23HQP, 23 February 2018.
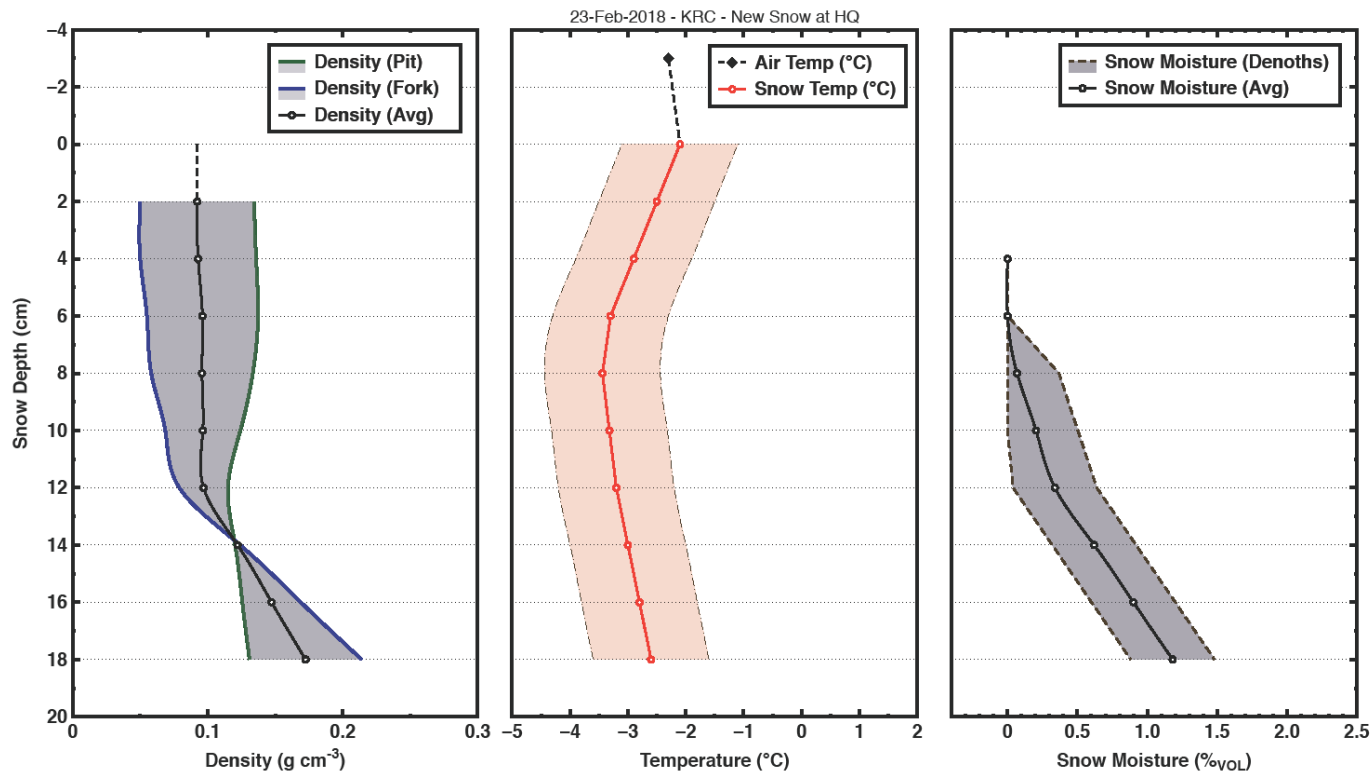
Figure C-16. Montana meteorological data for 24 January 2018.

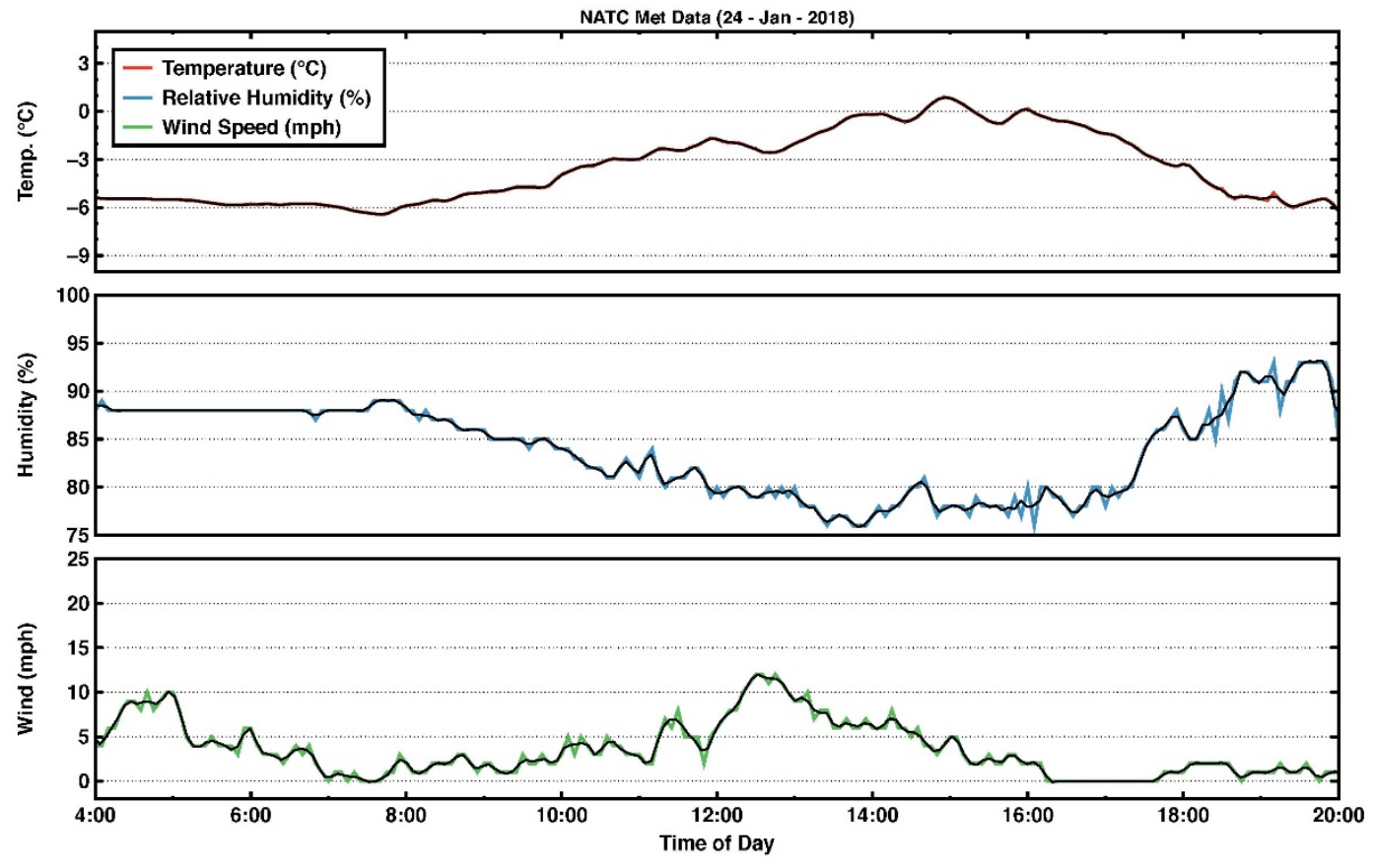

Figure C-17. Montana meteorological data for 25 January 2018.

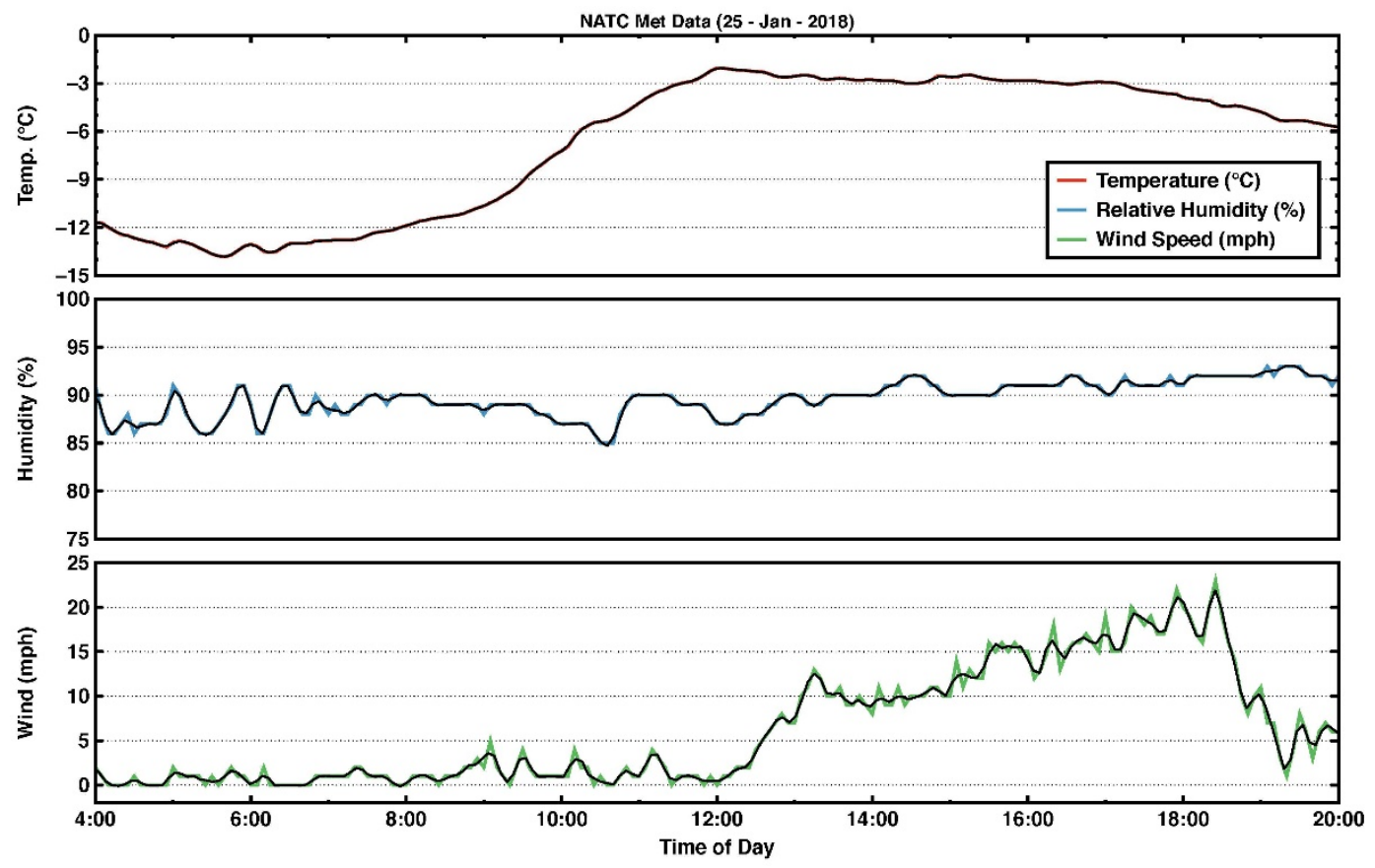


Figure C-18. Montana meteorological data for 26 January 2018.

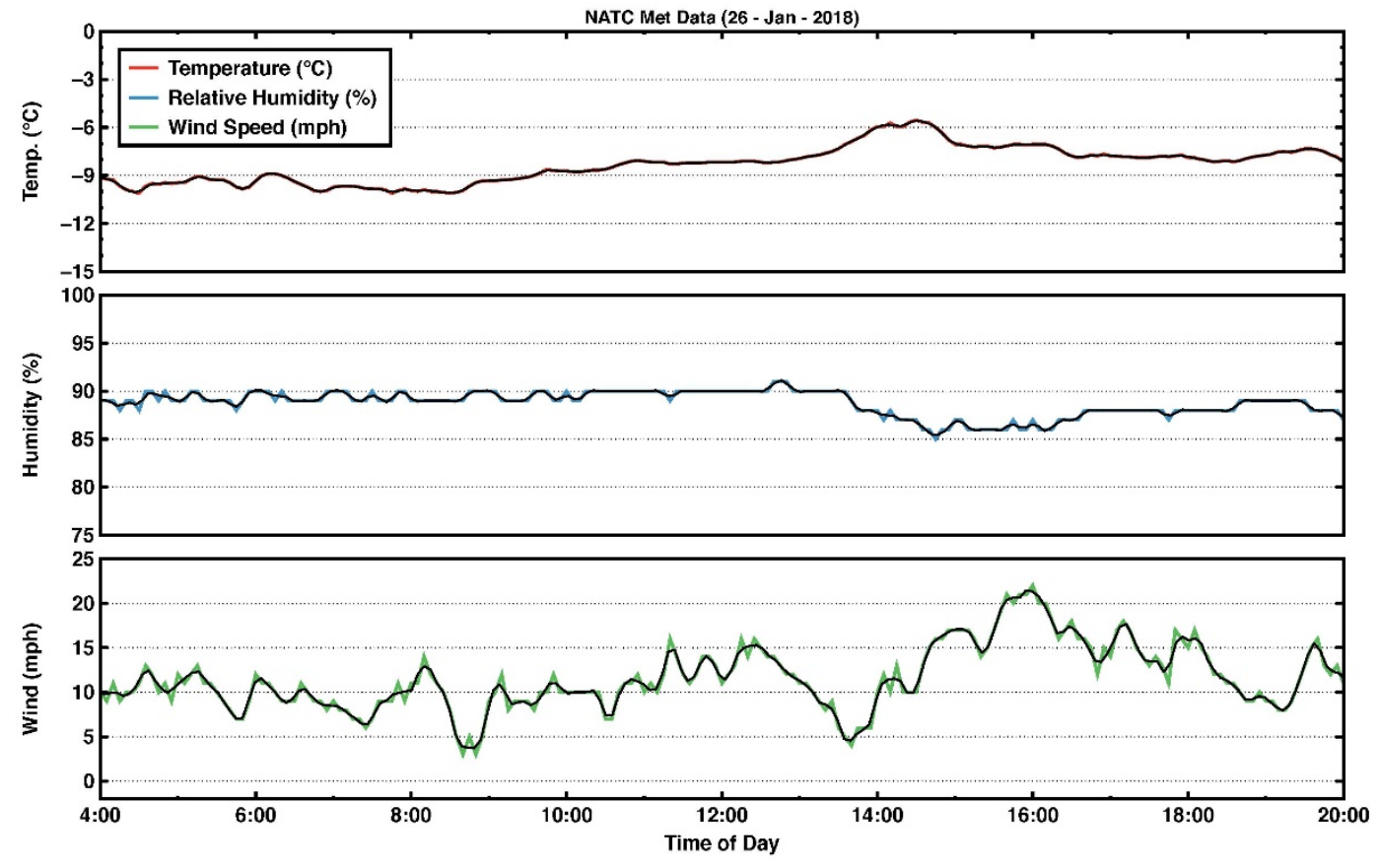

Figure C-19. Montana meteorological data for 27 January 2018.

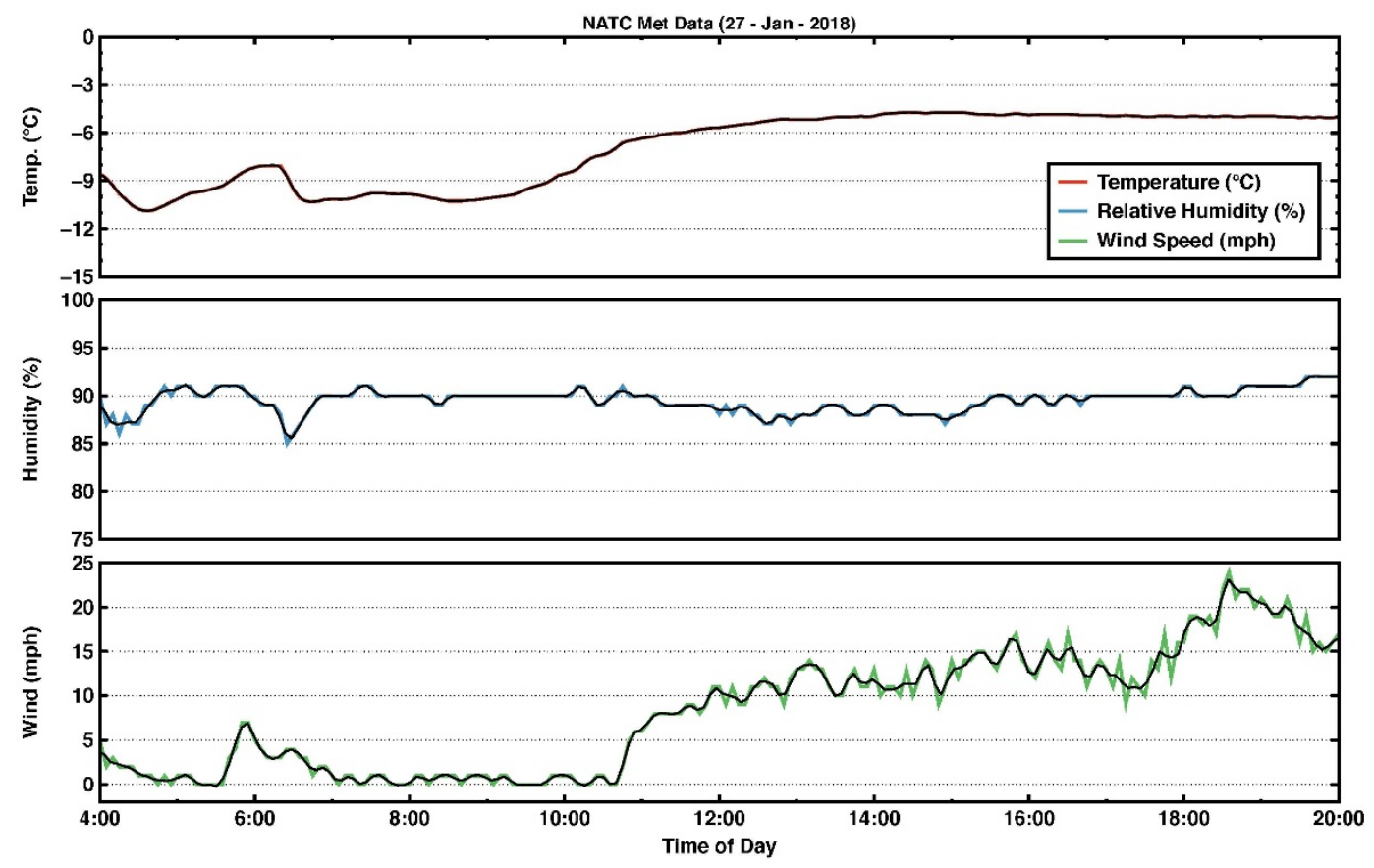


Figure C-20. Montana meteorological data for 28 January 2018.

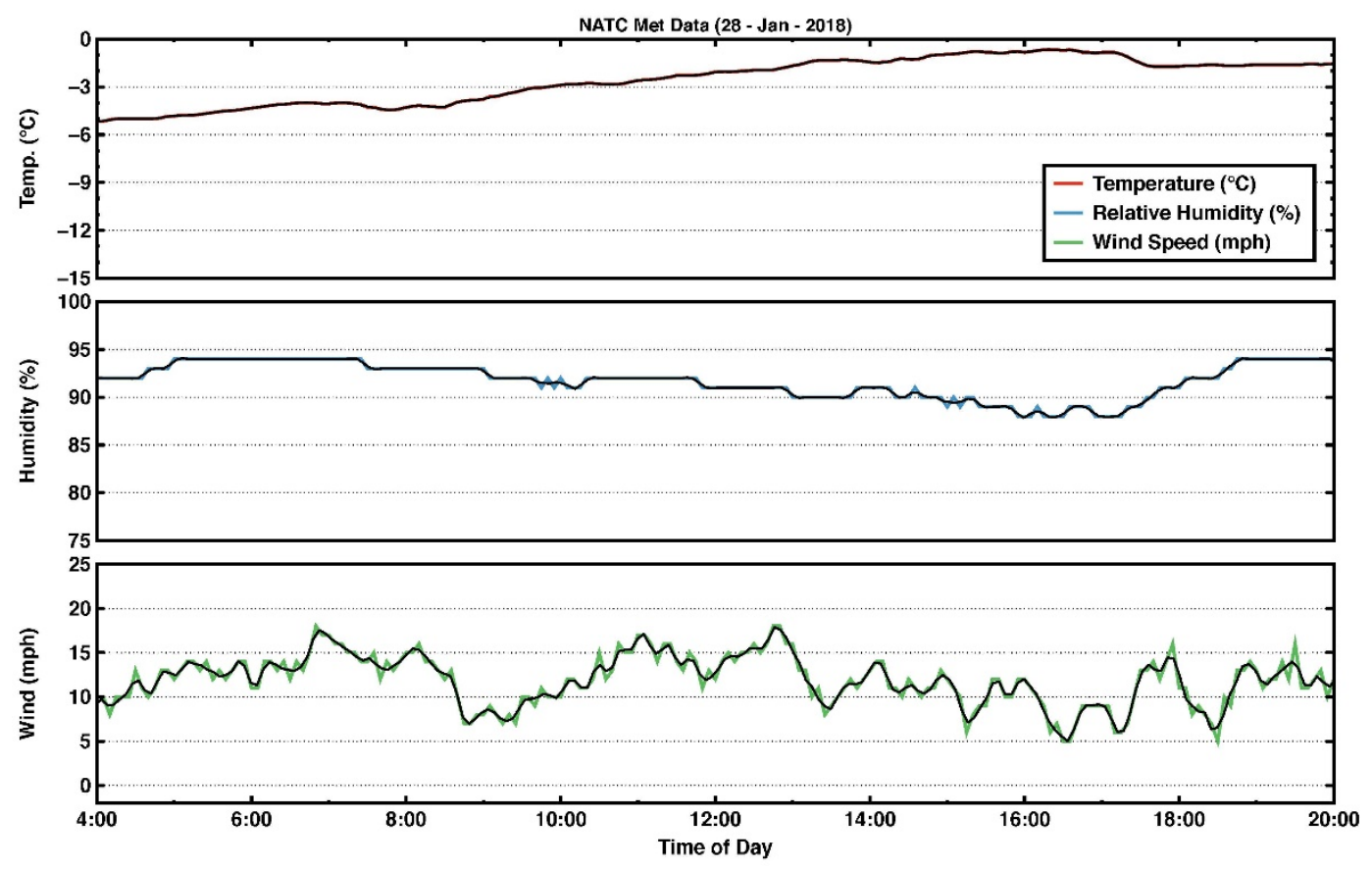

Figure C-21. Montana meteorological data for 29 January 2018.
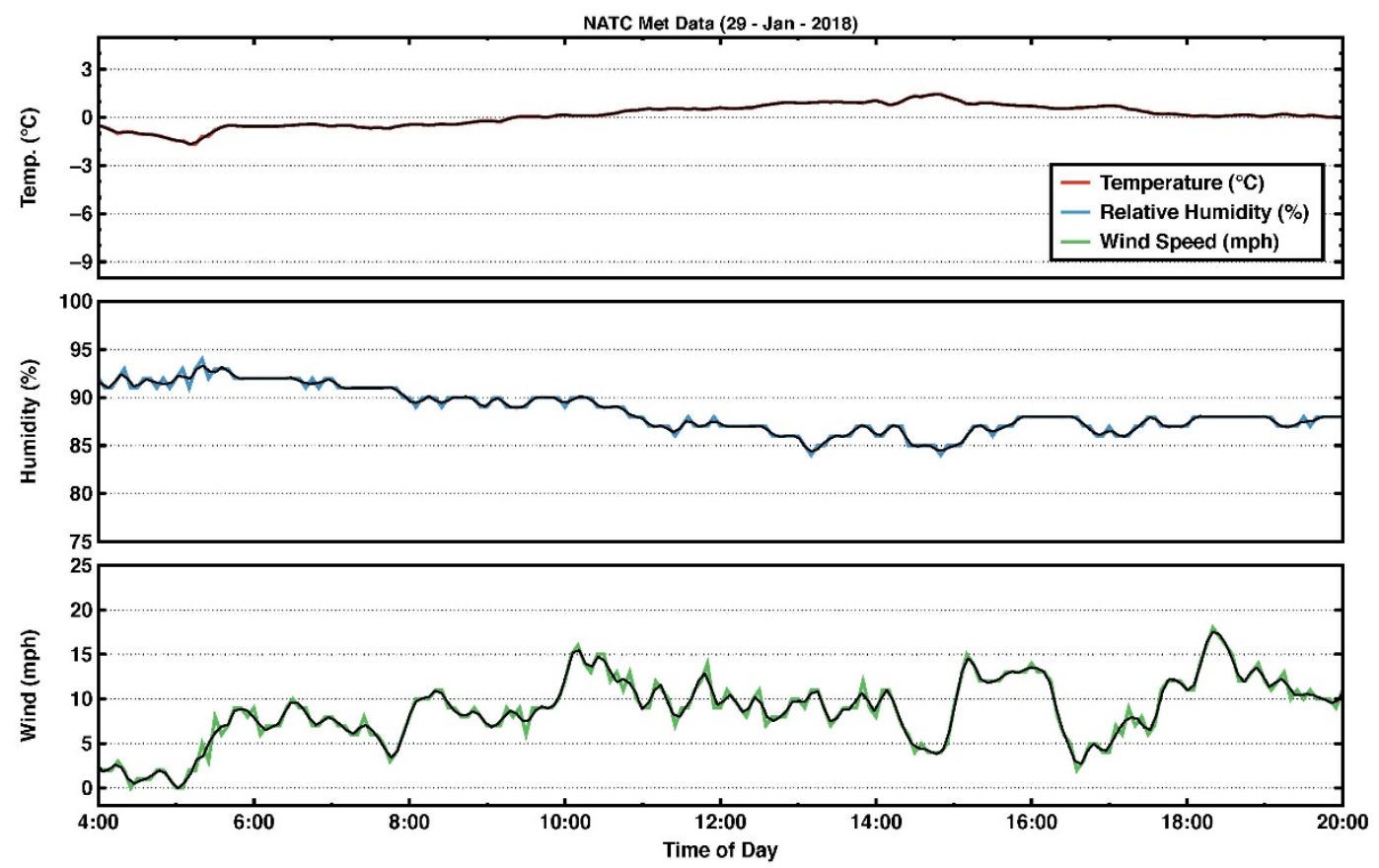
Figure C-22. Montana meteorological data for 30 January 2018.
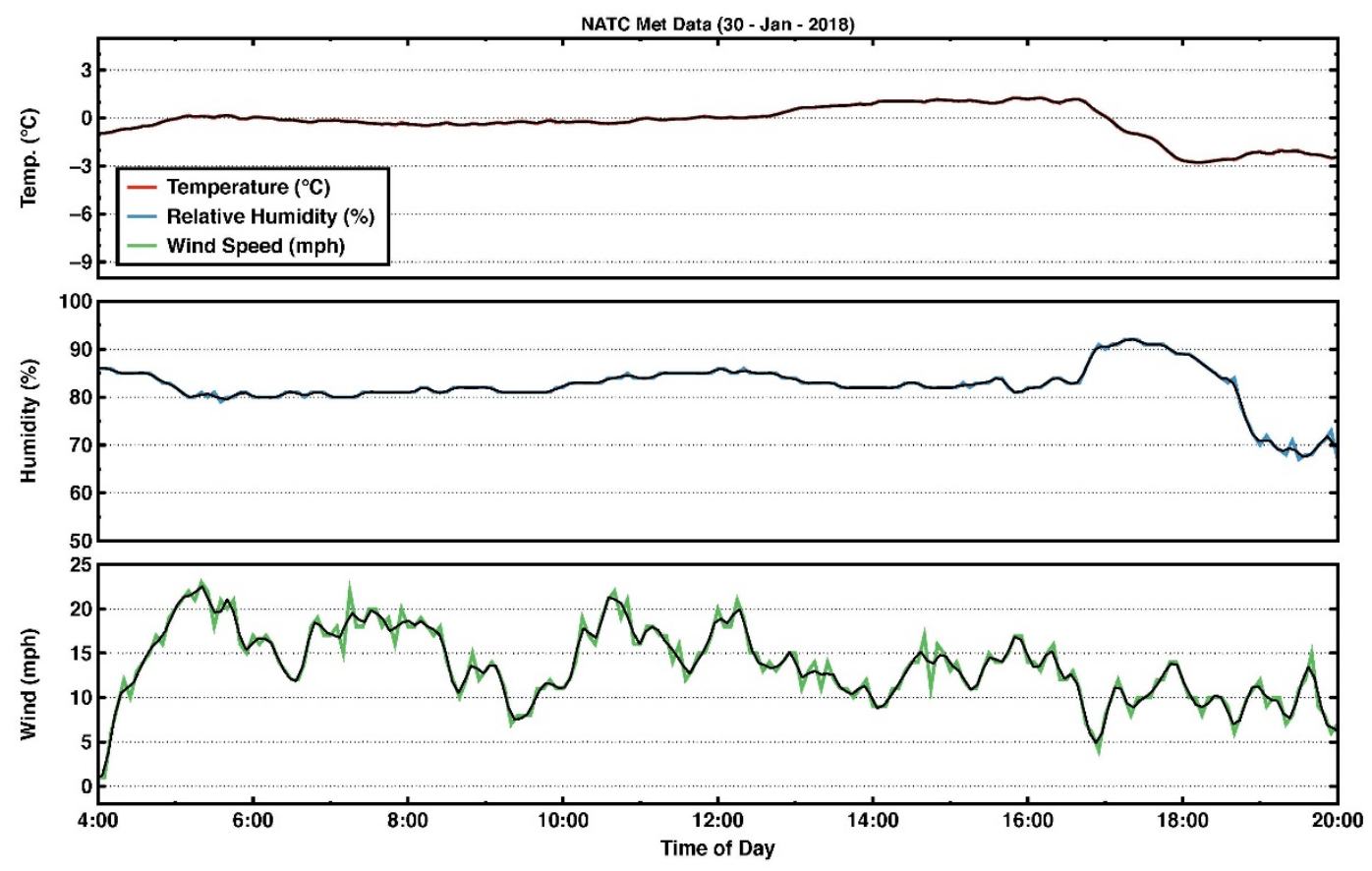

Figure C-23. Montana meteorological data for 31 January 2018.

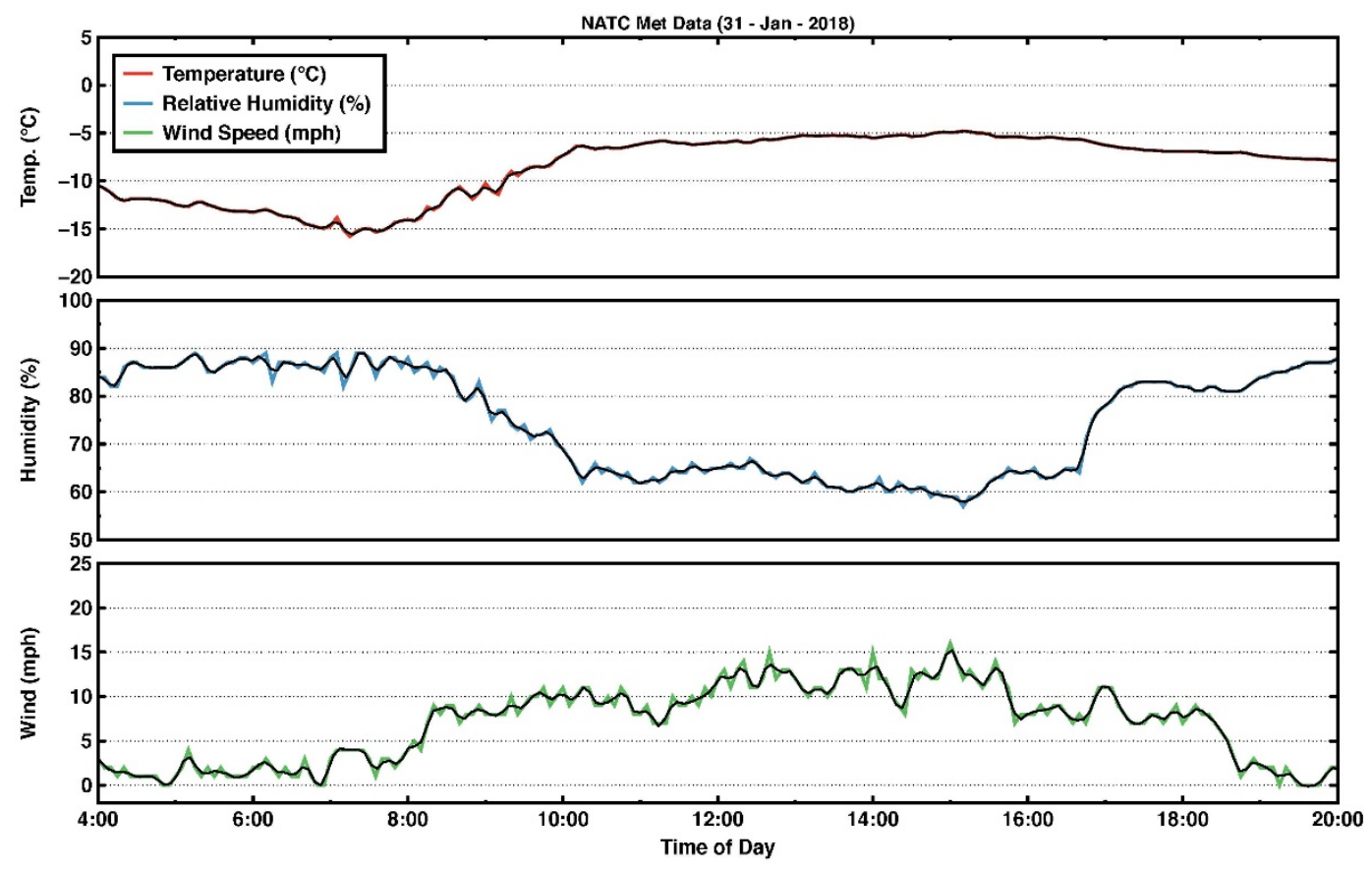


Figure C-24. Michigan meteorological data for 18 February 2018.
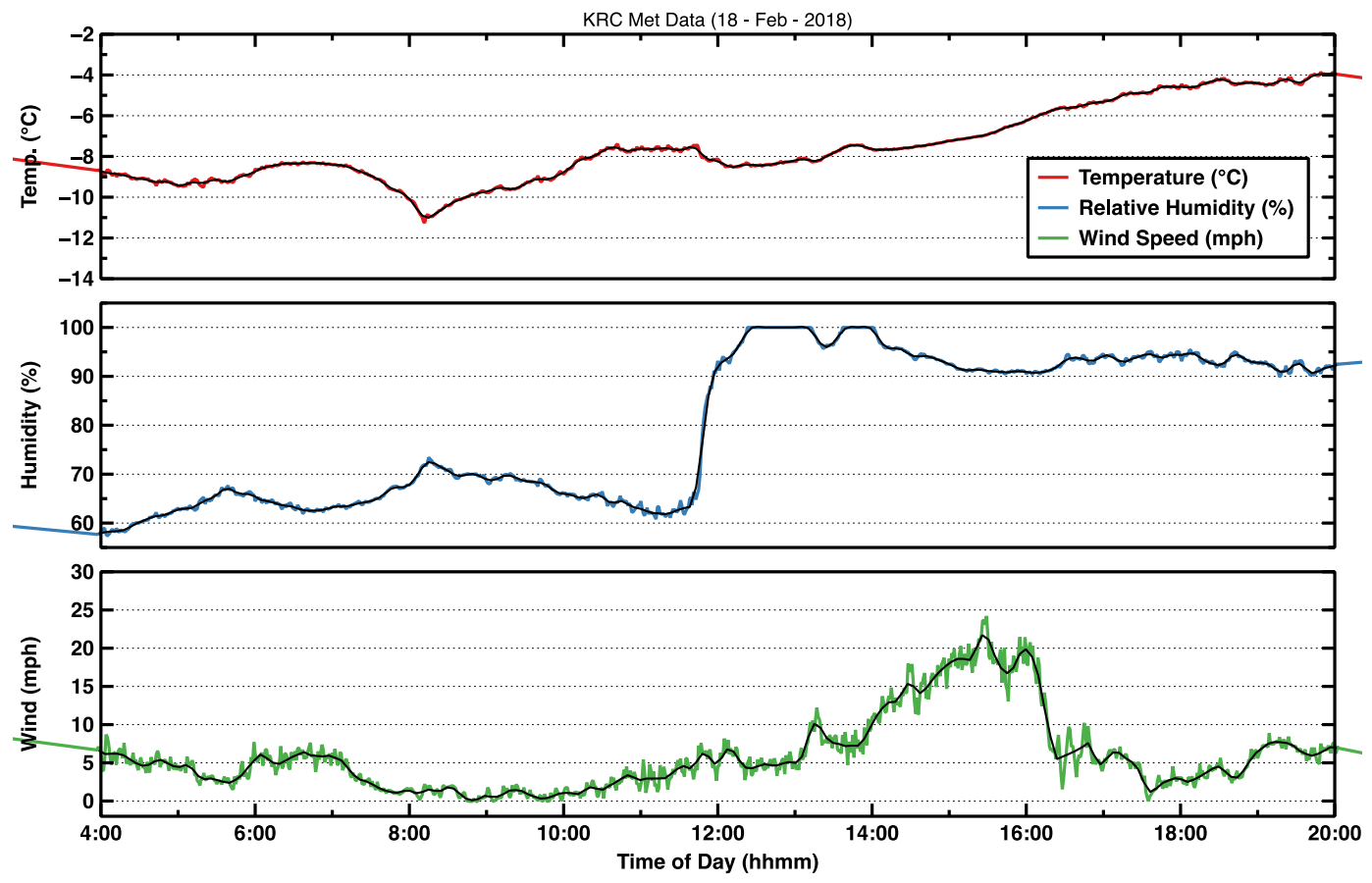

Figure C-25. Michigan meteorological data for 19 February 2018.
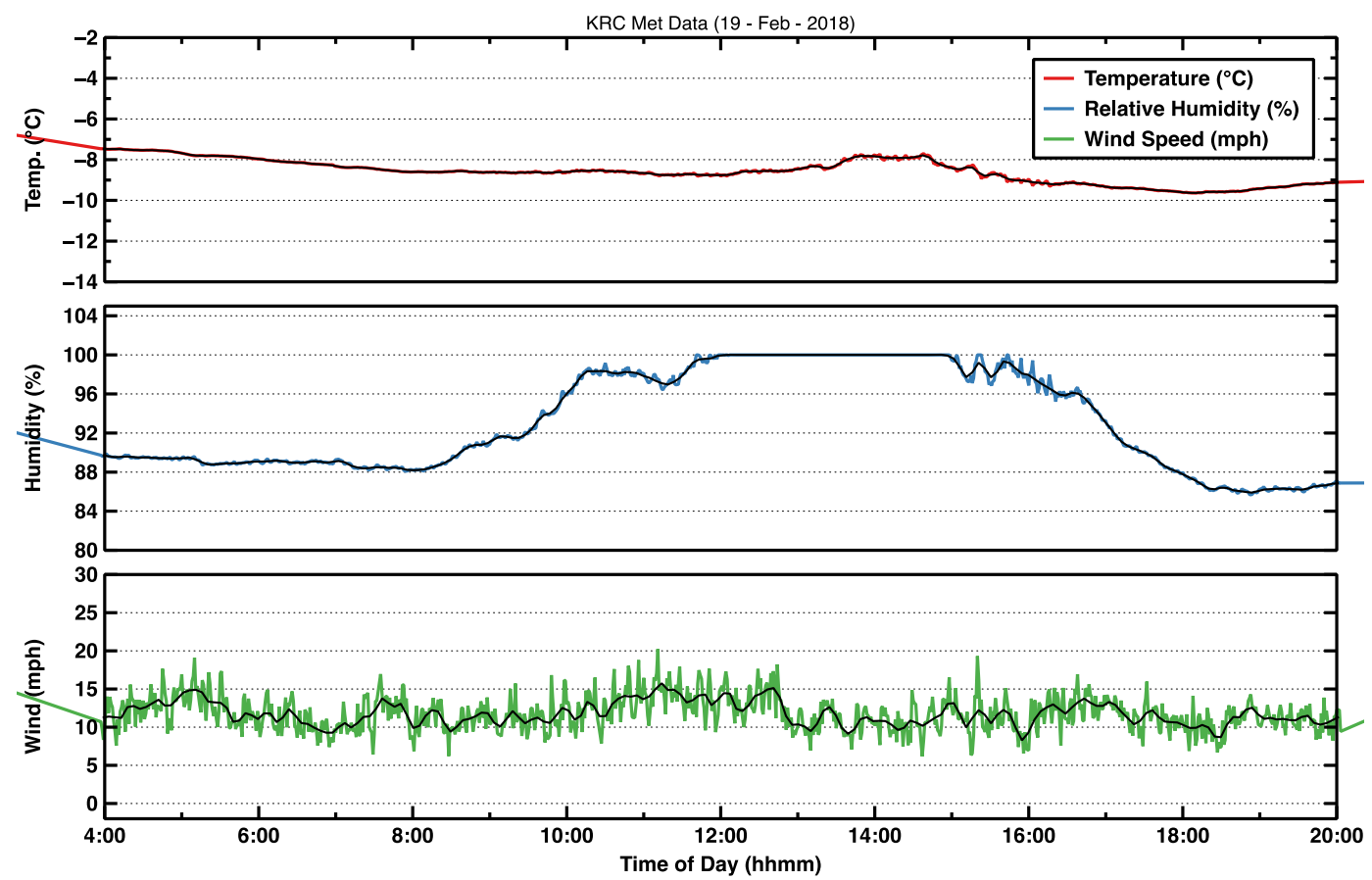
Figure C-26. Michigan meteorological data for 20 February 2018.

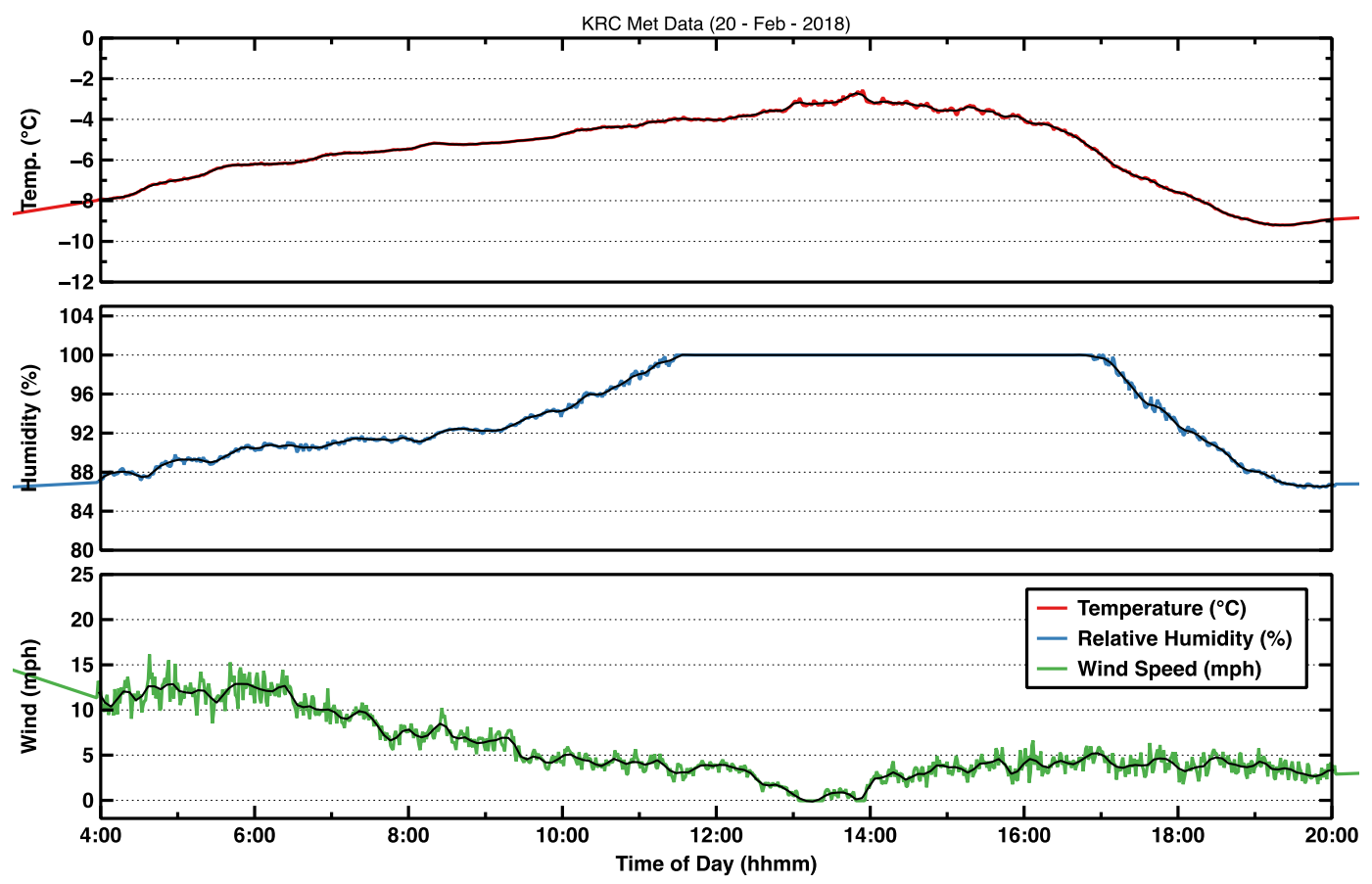

Figure C-27. Michigan meteorological data for 21 February 2018.
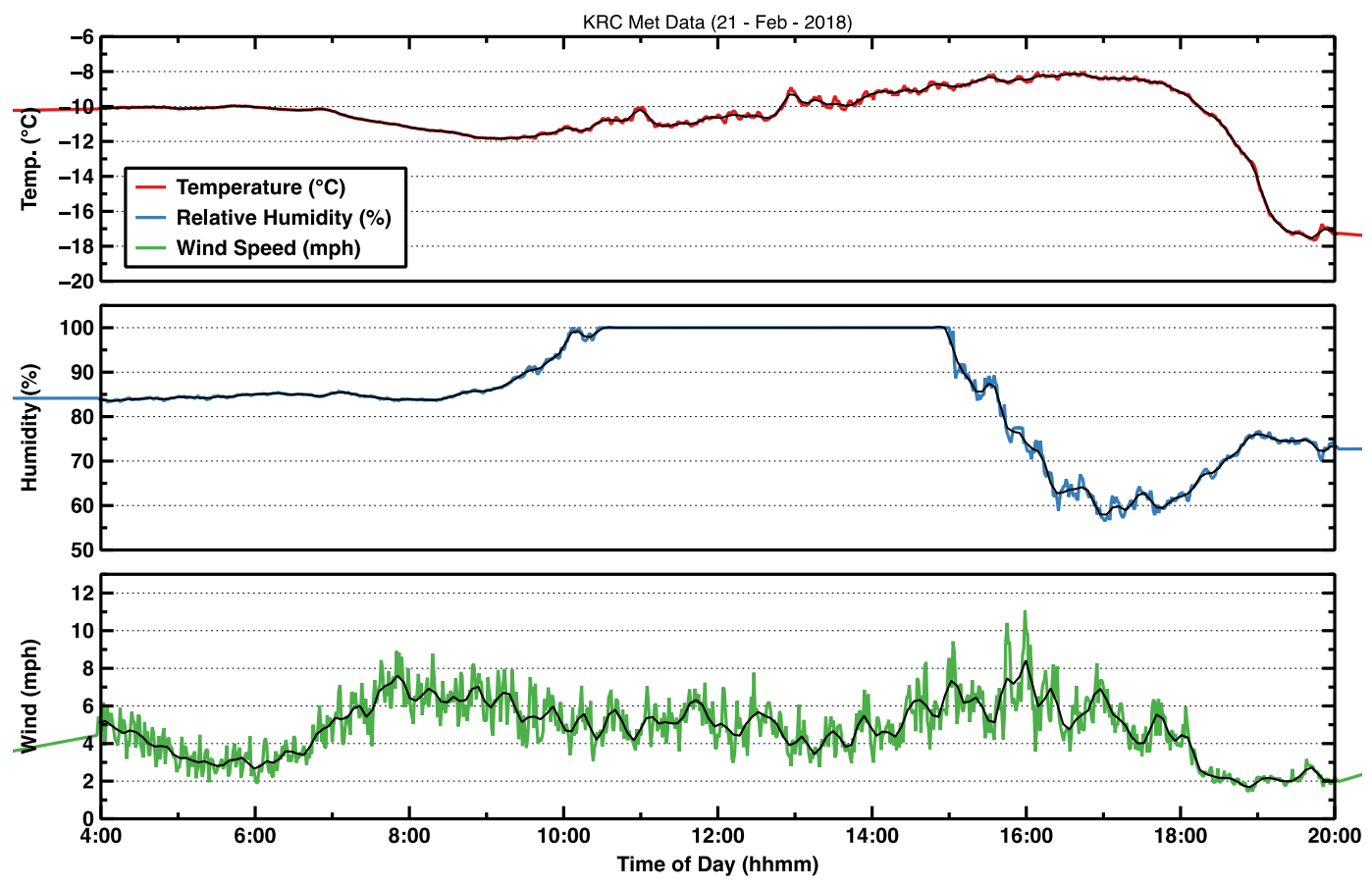
Figure C-28. Michigan meteorological data for 22 February 2018.
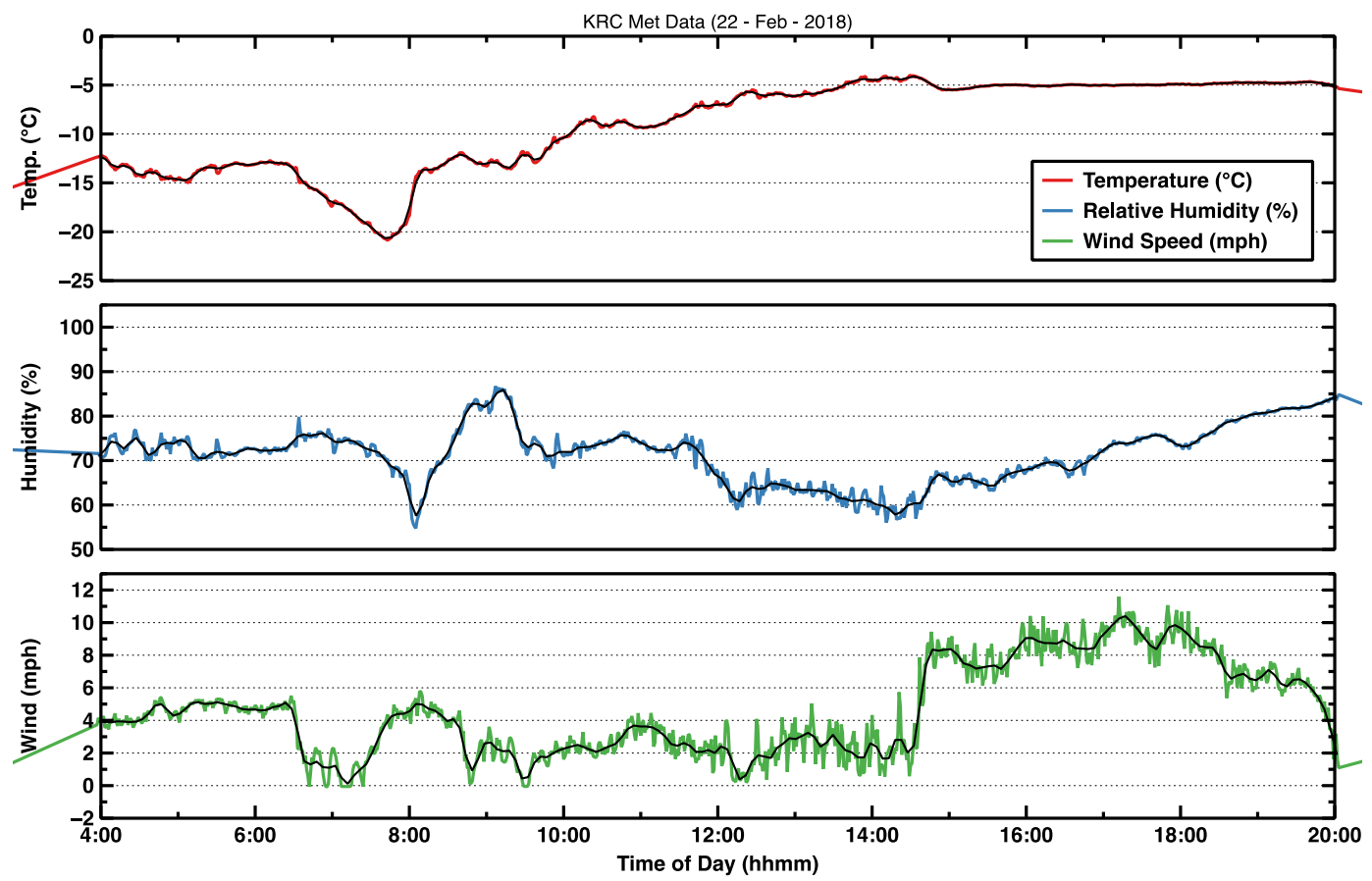

Figure C-29. Michigan meteorological data for 23 February 2018.

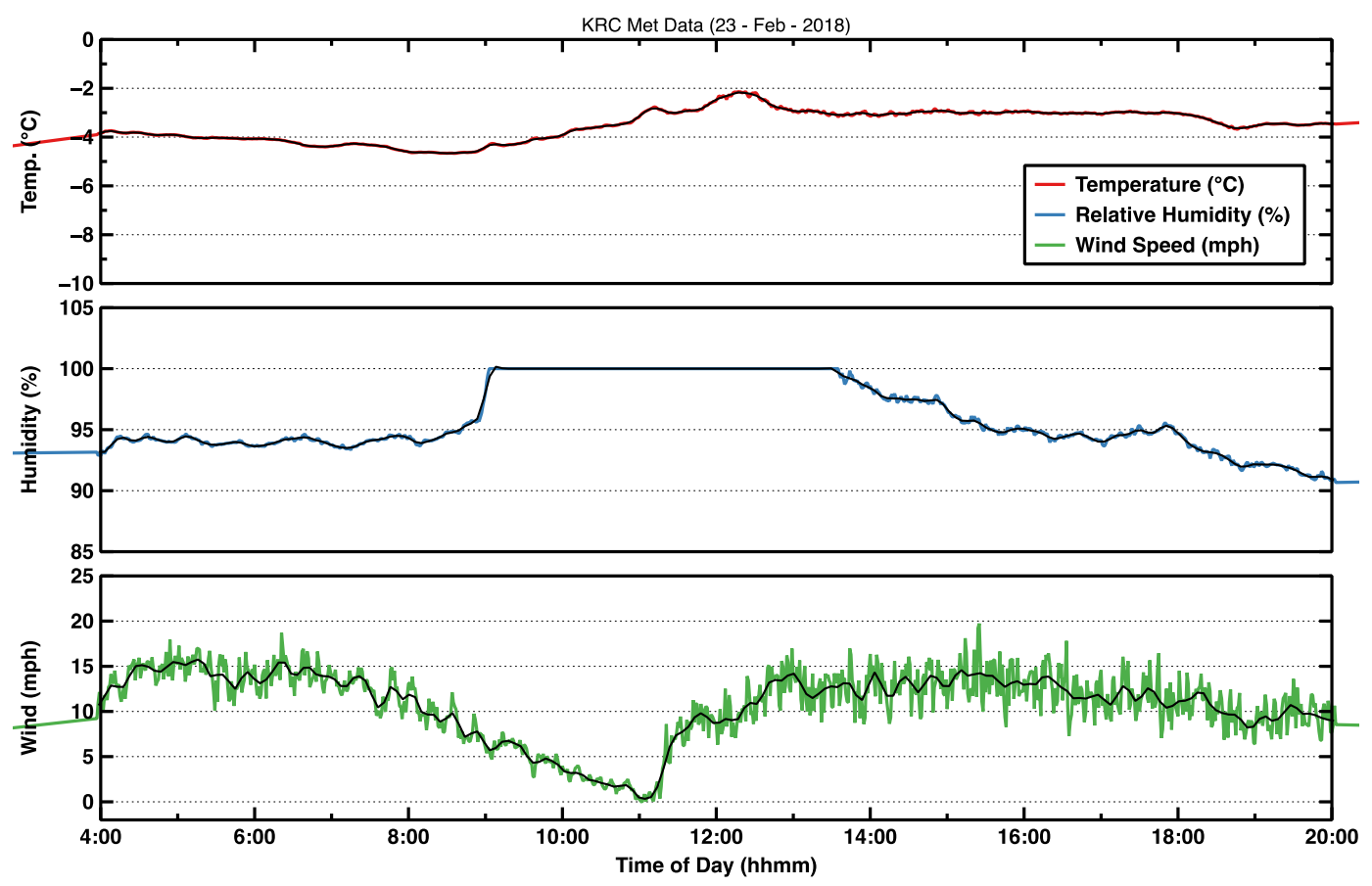




\section{Appendix D: Summary of Snow Measurements by Site}


Table D-1. Montana snow data summary.

\begin{tabular}{|c|c|c|c|c|c|c|c|c|c|c|c|c|c|c|c|c|c|c|c|c|}
\hline \multirow[b]{2}{*}{$\begin{array}{l}\text { Program } \\
\text { Title }\end{array}$} & \multirow[b]{2}{*}{$\begin{array}{c}\text { Air } \\
\text { Temp } \\
\left({ }^{\circ} \mathrm{C}\right)\end{array}$} & \multirow[b]{2}{*}{$\begin{array}{l}\text { Snow } \\
\text { Temp } \\
\left({ }^{\circ} \mathrm{C}\right)\end{array}$} & \multirow[b]{2}{*}{$\begin{array}{l}\text { Snow } \\
\text { Depth } \\
(\mathrm{cm})\end{array}$} & \multicolumn{2}{|c|}{ Snow Density } & \multirow{2}{*}{$\begin{array}{c}\text { Yamaha } \\
\text { Drop } \\
\text { Cone } \\
\text { (cm) }\end{array}$} & \multirow[b]{2}{*}{ CTI } & \multirow[b]{2}{*}{$\begin{array}{l}\text { Shear } \\
\text { Vane } \\
(\mathrm{kPa})\end{array}$} & \multirow[b]{2}{*}{$\begin{array}{l}\text { LWD } \\
\text { ISM }\end{array}$} & \multirow[b]{2}{*}{$\begin{array}{c}0.5 \\
\text { Clegg } 1\end{array}$} & \multirow[b]{2}{*}{$\begin{array}{c}0.5 \\
\text { Clegg2 }\end{array}$} & \multirow[b]{2}{*}{$\begin{array}{c}2.25 \\
\text { Clegg1 }\end{array}$} & \multirow[b]{2}{*}{$\begin{array}{c}2.25 \\
\text { Clegg } 2\end{array}$} & \multirow[b]{2}{*}{ CBR } & \multicolumn{3}{|c|}{ Ram Index } & \multicolumn{3}{|c|}{ RSP Index } \\
\hline & & & & $\begin{array}{c}\text { Top } \\
5 \mathrm{~cm} \\
\left(\mathrm{~g} / \mathrm{cm}^{3}\right)\end{array}$ & $\begin{array}{l}\text { Average } \\
\left(\mathrm{g} / \mathrm{cm}^{3}\right)\end{array}$ & & & & & & & & & & $\begin{array}{c}0- \\
150 \\
\mathrm{~mm}\end{array}$ & $\begin{array}{c}150+ \\
\mathrm{mm}\end{array}$ & $\begin{array}{c}\text { Full } \\
\text { Depth }\end{array}$ & $\begin{array}{c}0- \\
150 \\
\mathrm{~mm}\end{array}$ & $\begin{array}{c}150+ \\
\mathrm{mm}\end{array}$ & $\begin{array}{c}\text { Full } \\
\text { Depth }\end{array}$ \\
\hline 25RWYO & $\begin{array}{ll}-7.7 \\
\end{array}$ & -8.7 & & & & & & 82 & & 4.7 & 30.2 & 11 & 13.5 & 9.4 & & & & & & 410 \\
\hline 25RWY50 & & & & & & & & 64 & & 3.8 & 24.5 & 9.6 & 22.1 & & & & & & & 330 \\
\hline 25RWY100 & & & & & & & & 91 & & 7.4 & 27.5 & 11.9 & 14.1 & & & & & & & 156 \\
\hline 25TWYO & & & & & & & & 42 & & 4.4 & & 8.3 & 8.5 & & & & & & & \\
\hline 25 TWY50 & & & & & & & & & & 9.8 & & 7.8 & 18 & & & & & & & \\
\hline 25TWY100 & -9.7 & -11.8 & 30 & & & & & 55 & & 5 & & 3 & 12.8 & 19 & & & & & & \\
\hline 26MLPN & -14 & -17 & 40 & 0.18 & 0.22 & & & & & & & & & & & & & & & \\
\hline 27TWYSVS & -5.3 & -5.4 & 53 & 0.18 & 0.24 & & & & & & & & & & & & 2 & & & \\
\hline 27RWYSVS & -5.2 & -5.4 & 68 & 0.05 & 0.19 & & & & & & & & & & & & & & & \\
\hline 28MLPW & 0.5 & -0.2 & 62 & 0.11 & 0.21 & & & & & & & & & & & & 19 & & & \\
\hline \multicolumn{21}{|l|}{$28 \mathrm{MLPN}$} \\
\hline 28TWYS & 1.5 & 0.5 & 55 & 0.15 & 0.19 & & & & & & & & & & & & & & & \\
\hline 29RWYC & 0.3 & -1.1 & & & & & & & & & 28.0 & & 10.9 & 6.7 & & & & & & \\
\hline 30MLPN & & & & & & & & & & & & & & & & & 15 & & & \\
\hline 31RWYC & & & & & & & & & & & & & & & & & & & & \\
\hline
\end{tabular}

${ }_{1}^{1}$ Measurement taken on fresh snow over a groomed snow surface.

2 Measurement taken on groomed snow (fresh snow brushed off). 
Table D-2. Michigan snow data summary.

\begin{tabular}{|c|c|c|c|c|c|c|c|c|c|c|c|c|c|c|c|c|c|c|c|c|}
\hline \multirow[b]{2}{*}{$\begin{array}{c}\text { Program } \\
\text { Title }\end{array}$} & \multirow{2}{*}{$\begin{array}{c}\text { Air } \\
\text { Temp } \\
\left({ }^{\circ} \mathrm{C}\right)\end{array}$} & \multirow{2}{*}{$\begin{array}{l}\text { Snow } \\
\text { Temp } \\
\left({ }^{\circ} \mathrm{C}\right)\end{array}$} & \multirow{2}{*}{$\begin{array}{c}\text { Snow } \\
\text { Depth } \\
(\mathrm{cm})\end{array}$} & \multicolumn{2}{|c|}{ Snow Density } & \multirow{2}{*}{$\begin{array}{c}\text { Yamaha } \\
\text { Cone } \\
(\mathrm{cm})\end{array}$} & \multirow[b]{2}{*}{ CTI } & \multirow{2}{*}{$\begin{array}{l}\text { Shear } \\
\text { Vane } \\
(\mathrm{kPa})\end{array}$} & \multirow[b]{2}{*}{$\begin{array}{l}\text { LWD } \\
\text { ISM }\end{array}$} & \multirow[b]{2}{*}{$\begin{array}{c}0.5 \\
\text { Clegg1 }\end{array}$} & \multirow[b]{2}{*}{$\begin{array}{c}0.5 \\
\text { Clegg2 }\end{array}$} & \multirow[b]{2}{*}{$\begin{array}{c}2.25 \\
\text { Clegg1 }\end{array}$} & \multirow[b]{2}{*}{$\begin{array}{c}2.25 \\
\text { Clegg } 2\end{array}$} & \multirow[b]{2}{*}{ CBR } & \multicolumn{3}{|c|}{ Ram Index } & \multicolumn{3}{|c|}{ RSP Index } \\
\hline & & & & $\begin{array}{c}\text { Top } 5 \mathrm{~cm} \\
\left(\mathrm{~g} / \mathrm{cm}^{3}\right)\end{array}$ & $\begin{array}{l}\text { Average } \\
\left(\mathrm{g} / \mathrm{cm}^{3}\right)\end{array}$ & & & & & & & & & & $\begin{array}{c}\text { 0-150 } \\
\mathrm{mm}\end{array}$ & $\begin{array}{c}150+ \\
\mathrm{mm}\end{array}$ & \begin{tabular}{|c|} 
Full \\
Depth
\end{tabular} & \begin{tabular}{|c|}
$0-150$ \\
$\mathrm{~mm}$
\end{tabular} & \begin{tabular}{|c|}
$150+$ \\
$\mathrm{mm}$
\end{tabular} & \begin{tabular}{|c|} 
Full \\
Depth
\end{tabular} \\
\hline 19SU2_A & -7.8 & -7.6 & 35 & & & & 84.0 & 73 & & 36.7 & 49.3 & 22.7 & & & 720 & 338 & 593 & 93 & 361 & 258 \\
\hline 19SU2_B & & & 25 & & & & 78.7 & 55 & & 28.4 & 44.3 & 13.6 & & 20.9 & 453 & 194 & 393 & 36 & 54 & 44 \\
\hline 19SU2_C & & & 27.5 & 0.59 & & & 77.0 & $\max$ & & 19.7 & 37.7 & 15.1 & & 20.4 & 372 & 228 & 345 & 19 & 17 & 18 \\
\hline 19SU2_D & & & 26.5 & & & & 77.0 & 103 & & 22.9 & 37.6 & 15.3 & & & 344 & 147 & 330 & 49 & 32 & 44 \\
\hline 19SU2_E & & & 23 & & & & 75.3 & 80 & & 17.9 & 35.3 & 12.3 & & & 216 & 136 & 201 & 34 & 72 & 54 \\
\hline 19SU2_F & & & 31.5 & & & & 77.0 & 63 & & 21.9 & 42.3 & 22.3 & & & 417 & 223 & 360 & 50 & 67 & 59 \\
\hline 19SU2VS_A & -8.4 & -5.4 & 56 & 0.06 & 0.21 & 4.7 & & & & & & & & & & & & & & \\
\hline 19SU2VS_B & & & & & & 4.7 & & & & & & & & & & & & & & \\
\hline 19SU2VS_C & & & & & & 9.0 & & & & & & & & & & & & & & \\
\hline 19SU2VS_D & & & & & & 6.7 & & & & & & & & & & & & & & \\
\hline 19SU2VS_E & -8 & -6.1 & 70 & 0.04 & 0.23 & 5.4 & & & & & & & & & & & & & & \\
\hline 20LP1WG_1 & & & 21 & & & & 83.7 & $\max$ & & 23.9 & 55.1 & 16.9 & 37.9 & 14.7 & & & & 85 & 64 & 76 \\
\hline 20LP1WG_2 & & & 24.5 & & & & 79.3 & $\max$ & & 29.3 & 43.5 & 18.6 & 22.6 & 18.7 & & & & 64 & 154 & 111 \\
\hline 20LP1WG_3 & & & & & & & 82.7 & $\max$ & & 27.3 & 55.5 & 15.7 & 21.6 & & & & & 98 & 116 & 105 \\
\hline 20LP1GS_4 & & & 31 & & & & 81.7 & & & 21.2 & 45.9 & 15.6 & 18.2 & 18.2 & & & 762 & 61 & 40 & 53 \\
\hline 20LP1GS_5 & -0.4 & -2.4 & 29 & 0.55 & & & 80.7 & & & 32.6 & 49.7 & 19.8 & 20.4 & 17.8 & & & & 106 & 55 & 89 \\
\hline 20LP1GS_6 & & & 29.5 & & & & 83.7 & & & 19.0 & 43.9 & 18.1 & 21.2 & & & & & 104 & 70 & 91 \\
\hline 20GPVS & -2.4 & -3.1 & 68 & 0.07 & 0.26 & 4.2 & & & & & & & & & & & & & & \\
\hline 21SWP_1 & & & 19 & & & & 80.7 & $\max$ & & 24.0 & 51.1 & 21.8 & 19.8 & & & & 1032 & 118 & 150 & 123 \\
\hline 21SWP_2 & & & 22 & 0.34 & 0.28 & & 85.3 & 100 & & 32.9 & 45.4 & 20.2 & 25.0 & 24.6 & & & 878 & 158 & 33 & 148 \\
\hline 21SWP_3 & & & 21.5 & & & & 85.7 & 100 & & 46.6 & 39.5 & 19.5 & 13.1 & 13.0 & & & 760 & 119 & 132 & 121 \\
\hline 21IS_S & -9.6 & -6.1 & 17 & & & 3.6 & & $\max$ & & & & & & & & & & & & \\
\hline 21IS_L & -8.6 & -5.3 & 17 & & & 3.5 & & & & & & & & & & & & & & \\
\hline 21SU1_1 & & & 28 & & & & 74.2 & & & & 27.2 & & 15.4 & 14.5 & & & & 82 & 92 & 86 \\
\hline 21SU1_2 & & & 29 & & & & 75.7 & & & & 25.6 & & 12.3 & 16.2 & & & & 64 & 182 & 64 \\
\hline 21GPRD_1 & & & & & & & 75.7 & & & & & & 31.9 & & & & & & & \\
\hline 21GPRD_2 & & & 67 & & & & 75.7 & & & & & & & & & & & & & \\
\hline 21GPVS & & & & & & 4.7 & & & & & & & & & & & & & & \\
\hline 21SU2_A2 & & & & & & & 74.0 & 77 & & & & & 15.2 & & & & & & & \\
\hline 21SU2_B2 & & & & & & & 74.3 & DNP & & & & & & & & & & & & \\
\hline 22SU3_1 & & & 24 & & & & 78.0 & & & & 49.9 & & 27.1 & & & & & 86 & 160 & 121 \\
\hline
\end{tabular}


Table D-2 (cont.). Michigan snow data summary.

\begin{tabular}{|c|c|c|c|c|c|c|c|c|c|c|c|c|c|c|c|c|c|c|c|c|}
\hline \multirow[b]{2}{*}{$\begin{array}{c}\text { Program } \\
\text { Title }\end{array}$} & \multirow{2}{*}{$\begin{array}{c}\text { Air } \\
\text { Temp } \\
\left({ }^{\circ} \mathrm{C}\right)\end{array}$} & \multirow{2}{*}{$\begin{array}{c}\text { Snow } \\
\text { Temp } \\
\left({ }^{\circ} \mathrm{C}\right)\end{array}$} & \multirow{2}{*}{$\begin{array}{c}\text { Snow } \\
\text { Depth } \\
(\mathrm{cm})\end{array}$} & \multicolumn{2}{|c|}{ Snow Density } & \multirow{2}{*}{$\begin{array}{c}\text { Yamaha } \\
\text { Cone } \\
(\mathrm{cm})\end{array}$} & \multirow[b]{2}{*}{ CTI } & \multirow{2}{*}{$\begin{array}{l}\text { Shear } \\
\text { Vane } \\
\text { (kPa) }\end{array}$} & \multirow[b]{2}{*}{$\begin{array}{l}\text { LWD } \\
\text { ISM }\end{array}$} & \multirow[b]{2}{*}{$\begin{array}{c}0.5 \\
\text { Clegg }^{1}\end{array}$} & \multirow[b]{2}{*}{$\begin{array}{c}0.5 \\
\text { Clegg } 2\end{array}$} & \multirow[b]{2}{*}{$\begin{array}{c}2.25 \\
\text { Clegg1 }\end{array}$} & \multirow[b]{2}{*}{$\begin{array}{c}2.25 \\
\text { Clegg } 2\end{array}$} & \multirow[b]{2}{*}{ CBR } & \multicolumn{3}{|c|}{ Ram Index } & \multicolumn{3}{|c|}{ RSP Index } \\
\hline & & & & $\begin{array}{c}\text { Top } 5 \mathrm{~cm} \\
\left(\mathrm{~g} / \mathrm{cm}^{3}\right)\end{array}$ & $\begin{array}{l}\text { Average } \\
\left(\mathrm{g} / \mathrm{cm}^{3}\right)\end{array}$ & & & & & & & & & & $\begin{array}{c}0-150 \\
\mathrm{~mm}\end{array}$ & $\begin{array}{c}150+ \\
\mathrm{mm}\end{array}$ & $\begin{array}{l}\text { Full } \\
\text { Depth }\end{array}$ & $\begin{array}{c}0-150 \\
\mathrm{~mm}\end{array}$ & $\begin{array}{c}150+ \\
\mathrm{mm}\end{array}$ & $\begin{array}{c}\text { Full } \\
\text { Depth }\end{array}$ \\
\hline 22SU3_2 & -13.6 & -15 & 22 & & & & 84.0 & & & & 49.1 & & 27.2 & 13.4 & & & & 114 & 80 & 101 \\
\hline 22SU3_3 & & & 23.5 & & & & 82.7 & & & & 57.3 & & 23.2 & 34.8 & & & & 110 & 157 & 123 \\
\hline 22SU3VS & -9 & -14.5 & $65-91$ & 0.19 & 0.28 & & & & & & & & & & & & & & & \\
\hline 22SU3VS_1 & & & 76 & & & 1.9 & & & & & & & & & & & & & & \\
\hline 22SU3VS_6 & & & 74 & & & & & & & & & & & & & & & & & \\
\hline 22SU3VS_5 & & & 79 & & & & & & & & & & & & & & & & & \\
\hline 22SU3VS_3 & & & 83 & & & & & & & & & & & & & & & & & \\
\hline 22SU3VS_4 & & & 76 & & & & & & & & & & & & & & & & & \\
\hline 22SU2 & -7 & -9.2 & & & & & & DNP & & & & & 17.0 & & & & & & & \\
\hline $22 \mathrm{SU} 3$ & -6 & -11.1 & & & & & & & & & & & & & & & & & & \\
\hline 22SU3_2OD & -4.8 & -10.1 & & & & & & & & & & & & & & & & & & \\
\hline \multicolumn{21}{|l|}{ 22SU3_15D } \\
\hline 22SU3_10D & -11.4 & -5 & & & & & & & & & & & & & & & & & & \\
\hline \multicolumn{21}{|l|}{ 22SU3_7D } \\
\hline 22LP3E & -6 & -11.2 & & & & & 75.7 & DNP & & & & & 22.3 & & & & & & & \\
\hline 22LP3EVS & -5.3 & -7.4 & & & & 1.1 & $x$ & & & & & & & & & & & & & \\
\hline 22IR_I & -8.6 & -5.3 & & 0.19 & 0.21 & & 95.3 & DNP & & & & & & & & & & & & \\
\hline 22IR_S & -9.6 & -6.1 & & 0.02 & 0.10 & & 87.3 & DNP & & & & & 34.4 & & & & & & & \\
\hline 22IR_AC & & & & & & & & DNP & & & & & & & & & & & & \\
\hline 22STAB_S & -6.5 & -8.7 & & & & & 87.3 & & & & & & 34.2 & & & & & & & \\
\hline 22STAB_GI & & & & & & & & DNP & & & & & & & & & & & & \\
\hline 22VDA2_1 & -6.9 & -8.2 & & & & & 82.0 & DNP & & & & & 26.3 & & & & & & & \\
\hline $22900 \mathrm{C}$ & -5.3 & -8.1 & & & & & 87.3 & DNP & & & & & 37.8 & & & & & & & \\
\hline $22300 \mathrm{C}$ & -6 & -8 & & & & & 82.7 & DNP & & & & & 16.1 & & & & & & & \\
\hline $22300 \mathrm{CVS}$ & -6 & -4.6 & & & & & & & & & & & & & & & & & & \\
\hline 22LP4 & -5 & -7 & & & & & 85.3 & DNP & & & & & 30.8 & & & & & & & \\
\hline 22LP4VS & -4.8 & -1.8 & & & & 0.6 & & & & & & & & & & & & & & \\
\hline 22LP3NW & -4 & -7 & & & & & 82.0 & DNP & & & & & 25.6 & & & & & & & \\
\hline 22LP3NWVS & -2.6 & -2.3 & & & & 1.9 & & & & & & & & & & & & & & \\
\hline 22STAB_GI2 & & & & & & & & DNP & & & & & & & & & & & & \\
\hline $23 \mathrm{HQP}$ & -2.3 & -2.1 & 16 & 0.13 & 0.13 & 3.6 & & & & & & & & & & & & & & \\
\hline
\end{tabular}

${ }^{1}$ Measurement taken on fresh snow over a groomed snow surface.

2 Measurement taken on groomed snow (fresh snow brushed off). 
Table D-3. Montana Clegg data.

\begin{tabular}{|c|c|c|c|c|c|c|c|c|c|c|}
\hline \multirow[b]{2}{*}{ Site } & \multirow[b]{2}{*}{ Snow surface } & \multirow[b]{2}{*}{ Test } & \multicolumn{4}{|c|}{0.5 kg Clegg } & \multicolumn{4}{|c|}{2.25 kg Clegg } \\
\hline & & & Drop 1 & Drop 2 & Drop 3 & Drop 4 & Drop 1 & Drop 2 & Drop 3 & Drop 4 \\
\hline 25RWYO & Fresh snow over groomed & 1 & 1 & 2.5 & 3.5 & 4.7 & 0 & 6 & 11 & 17.1 \\
\hline 25RWY50 & Fresh snow over groomed & 1 & 0.8 & 1.8 & 2.7 & 3.8 & 3.9 & 9.1 & 9.6 & 14.4 \\
\hline 25RWY100 & Fresh snow over groomed & 1 & 1.4 & 3.6 & 6 & 7.4 & 5.5 & 9.9 & 11.9 & 14 \\
\hline 25RWYO & Groomed & 1 & 13.4 & 16.3 & 23.5 & 30.2 & 6.6 & 10.5 & 13.5 & 13.5 \\
\hline 25RWY50 & Groomed & 1 & 6.4 & 12 & 17.4 & 24.5 & 10.7 & 17.6 & 22.1 & 22.6 \\
\hline 25RWY100 & Groomed & 1 & 10.1 & 17.5 & 24.6 & 27.5 & 6.6 & 11.4 & 14.1 & 13.9 \\
\hline 25TWYO & Fresh snow over Groomed & 1 & 0.7 & 2 & 3.4 & 4.4 & 2.4 & 5.7 & 8.3 & 11.2 \\
\hline 25TWY50 & Fresh snow over Groomed & 1 & 1.7 & 2.2 & 6.7 & 9.8 & 2.4 & 6.2 & 7.8 & 10.3 \\
\hline 25TWY100 & Fresh snow over Groomed & 1 & 0 & 2.2 & 3.2 & 5 & 0 & 0 & 3 & 8.9 \\
\hline 25TWYO & Groomed & 1 & & & & & 5.5 & 7.4 & 8.5 & 11.2 \\
\hline 25TWY50 & Groomed & 1 & & & & & 19.1 & 19.9 & 18 & 21 \\
\hline 25TWY100 & Groomed & 1 & & & & & 7.4 & 10.3 & 12.8 & 15.7 \\
\hline 29CRWY & Groomed & 1 & 6.2 & 7.3 & 6.8 & 10.2 & 5.1 & 7.1 & 8.8 & 14.1 \\
\hline 29CRWY & Groomed & 2 & 8.5 & 14.4 & 16.6 & 21 & 8.8 & 13.7 & 17 & 19.2 \\
\hline 29CRWY & Groomed & 3 & 6.6 & 12.2 & 17.6 & 17.3 & 4 & 5.7 & 6.9 & 9.3 \\
\hline 30CRWY_1 & Groomed & 1 & 6.8 & 16.6 & 20.9 & 35.2 & & & & \\
\hline 30CRWY_1 & Groomed & 2 & 3.4 & 6.5 & 17.5 & 22.6 & & & & \\
\hline 30CRWY_1 & Groomed & 3 & 4.7 & 11.6 & 19.6 & 30.5 & & & & \\
\hline 30CRWY_2 & Groomed & 1 & 34.8 & 36.9 & 33.8 & 45 & & & & \\
\hline 30CRWY_2 & Groomed & 2 & 14.3 & 23.4 & 28.5 & 33.3 & & & & \\
\hline 30CRWY_2 & Groomed & 3 & 14.9 & 24 & 30.8 & 36.8 & & & & \\
\hline
\end{tabular}


Table D-4. Michigan Clegg data.

\begin{tabular}{|c|c|c|c|c|c|c|c|c|c|c|}
\hline \multirow[b]{2}{*}{ Site } & \multirow[b]{2}{*}{ Snow surface } & \multirow[b]{2}{*}{ Test } & \multicolumn{4}{|c|}{0.5 kg Clegg } & \multicolumn{4}{|c|}{2.25 kg Clegg } \\
\hline & & & Drop 1 & Drop 2 & Drop 3 & Drop 4 & Drop 1 & Drop 2 & Drop 3 & Drop 4 \\
\hline 19SU2_A & Fresh snow over Groomed & 1 & 13 & 23.7 & 29 & 35.3 & 13 & 23.7 & 29 & 35.3 \\
\hline 19SU2_A & Fresh snow over Groomed & 2 & 18.9 & 22.1 & 24.6 & 29 & 18.9 & 22.1 & 24.6 & 29 \\
\hline 19SU2_A & Fresh snow over Groomed & 3 & 8.3 & 11.2 & 14.4 & 19.6 & 8.3 & 11.2 & 14.4 & 19.6 \\
\hline 19SU2_B & Fresh snow over Groomed & 1 & 11.2 & 14.4 & 11.4 & 13.5 & 11.2 & 14.4 & 11.4 & 13.5 \\
\hline 19SU2_B & Fresh snow over Groomed & 2 & 8.2 & 11.4 & 12.1 & 15.1 & 8.2 & 11.4 & 12.1 & 15.1 \\
\hline 19SU2_B & Fresh snow over Groomed & 3 & 6.6 & 11.6 & 17.4 & 15.7 & 6.6 & 11.6 & 17.4 & 15.7 \\
\hline 19SU2_C & Fresh snow over Groomed & 1 & 9.9 & 13.2 & 15.8 & 18.3 & 9.9 & 13.2 & 15.8 & 18.3 \\
\hline 19SU2_C & Fresh snow over Groomed & 2 & 6.2 & 14.8 & 17.3 & 21.2 & 6.2 & 14.8 & 17.3 & 21.2 \\
\hline 19SU2_C & Fresh snow over Groomed & 3 & 5.5 & 12.6 & 12.1 & 12.3 & 5.5 & 12.6 & 12.1 & 12.3 \\
\hline 19SU2_D & Fresh snow over Groomed & 1 & 13.9 & 16 & 16.9 & 17.1 & 13.9 & 16 & 16.9 & 17.1 \\
\hline 19SU2_D & Fresh snow over Groomed & 2 & 8.5 & 13.2 & 14.4 & 14.1 & 8.5 & 13.2 & 14.4 & 14.1 \\
\hline 19SU2_D & Fresh snow over Groomed & 3 & 9.8 & 13.5 & 14.6 & 15.3 & 9.8 & 13.5 & 14.6 & 15.3 \\
\hline 19SU2_E & Fresh snow over Groomed & 1 & 6.6 & 11.2 & 11.2 & 13.5 & 6.6 & 11.2 & 11.2 & 13.5 \\
\hline 19SU2_E & Fresh snow over Groomed & 2 & 4.1 & 8.2 & 9.9 & 13.7 & 4.1 & 8.2 & 9.9 & 13.7 \\
\hline 19SU2_E & Fresh snow over Groomed & 3 & 5.8 & 11.4 & 15.8 & 17.4 & 5.8 & 11.4 & 15.8 & 17.4 \\
\hline 19SU2_F & Fresh snow over Groomed & 1 & 11.7 & 18.7 & 21.2 & 22.4 & 11.7 & 18.7 & 21.2 & 22.4 \\
\hline 19SU2_F & Fresh snow over Groomed & 2 & 14.4 & 18.9 & 23 & 24.9 & 14.4 & 18.9 & 23 & 24.9 \\
\hline 19SU2_F & Fresh snow over Groomed & 3 & 15.1 & 19.4 & 22.6 & 24.4 & 15.1 & 19.4 & 22.6 & 24.4 \\
\hline 20LP1WG_1 & Fresh snow over Groomed & 1 & 29 & 18.5 & 24.4 & 29.6 & 29 & 18.5 & 24.4 & 29.6 \\
\hline 20LP1WG_1 & Fresh snow over Groomed & 2 & 8.3 & 10.1 & 13.3 & 18.2 & 8.3 & 10.1 & 13.3 & 18.2 \\
\hline 20LP1WG_1 & Fresh snow over Groomed & 3 & 9.4 & 13.9 & 13 & 18.9 & 9.4 & 13.9 & 13 & 18.9 \\
\hline 20LP1WG_1 & Groomed & 1 & 19.2 & 24.2 & 31.2 & 35.7 & 19.2 & 24.2 & 31.2 & 35.7 \\
\hline 20LP1WG_1 & Groomed & 2 & 30.1 & 40.8 & 46.5 & 38.2 & 30.1 & 40.8 & 46.5 & 38.2 \\
\hline 20LP1WG_1 & Groomed & 3 & 32.4 & 54.1 & 36 & 57.6 & 32.4 & 54.1 & 36 & 57.6 \\
\hline 20LP1WG_2 & Fresh snow over Groomed & 1 & 2.6 & 12.4 & 17.1 & 24.2 & 2.6 & 12.4 & 17.1 & 24.2 \\
\hline 20LP1WG_2 & Fresh snow over Groomed & 2 & 8.2 & 18.3 & 17.4 & 29.6 & 8.2 & 18.3 & 17.4 & 29.6 \\
\hline 20LP1WG_2 & Fresh snow over Groomed & 3 & 11.2 & 17.1 & 21.4 & 26.5 & 11.2 & 17.1 & 21.4 & 26.5 \\
\hline 20LP1WG_2 & Groomed & 1 & 15.1 & 18.9 & 20.1 & 22.3 & 15.1 & 18.9 & 20.1 & 22.3 \\
\hline 20LP1WG_2 & Groomed & 2 & 21.2 & 21.7 & 22.3 & 21.2 & 21.2 & 21.7 & 22.3 & 21.2 \\
\hline 20LP1WG_2 & Groomed & 3 & 17.4 & 20.3 & 25.5 & 29.4 & 17.4 & 20.3 & 25.5 & 29.4 \\
\hline 20LP1WG_3 & Fresh snow over Groomed & 1 & 8.3 & 16.2 & 13.5 & 16.4 & 8.3 & 16.2 & 13.5 & 16.4 \\
\hline 20LP1WG_3 & Fresh snow over Groomed & 2 & 0 & 13.2 & 15.3 & 19.6 & 0 & 13.2 & 15.3 & 19.6 \\
\hline 20LP1WG_3 & Fresh snow over Groomed & 3 & 6 & 11.2 & 18.2 & 23 & 6 & 11.2 & 18.2 & 23 \\
\hline 20LP1WG_3 & Groomed & 1 & 12.8 & 15.5 & 21.4 & 21.6 & 12.8 & 15.5 & 21.4 & 21.6 \\
\hline 20LP1WG_3 & Groomed & 2 & 18.7 & 18.9 & 23.5 & 23.9 & 18.7 & 18.9 & 23.5 & 23.9 \\
\hline 20LP1WG_3 & Groomed & 3 & 14.4 & 13.9 & 19.9 & 26.7 & 14.4 & 13.9 & 19.9 & 26.7 \\
\hline 20LP1GS_4 & Fresh snow over Groomed & 1 & 3.3 & 7.8 & 10.8 & 14.4 & 3.3 & 7.8 & 10.8 & 14.4 \\
\hline 20LP1GS_4 & Fresh snow over Groomed & 2 & 7.8 & 16 & 20.3 & 21.6 & 7.8 & 16 & 20.3 & 21.6 \\
\hline 20LP1GS_4 & Fresh snow over Groomed & 3 & 9.1 & 14.2 & 15.7 & 19.4 & 9.1 & 14.2 & 15.7 & 19.4 \\
\hline 20LP1GS_4 & Groomed & 1 & 10.5 & 13.7 & 15.8 & 16 & 10.5 & 13.7 & 15.8 & 16 \\
\hline 20LP1GS_4 & Groomed & 2 & 5.5 & 11.4 & 18.7 & 20.7 & 5.5 & 11.4 & 18.7 & 20.7 \\
\hline
\end{tabular}


Table D-4 (cont.). Michigan Clegg data.

\begin{tabular}{|c|c|c|c|c|c|c|c|c|c|c|}
\hline \multirow[b]{2}{*}{ Site } & \multirow[b]{2}{*}{ Snow surface } & \multirow[b]{2}{*}{ Test } & \multicolumn{4}{|c|}{0.5 kg Clegg } & \multicolumn{4}{|c|}{$2.25 \mathrm{~kg}$ Clegg } \\
\hline & & & Drop 1 & Drop 2 & Drop 3 & Drop 4 & Drop 1 & Drop 2 & Drop 3 & Drop 4 \\
\hline 20LP1GS_4 & Groomed & 3 & 15.5 & 18.3 & 20.1 & 25.8 & 15.5 & 18.3 & 20.1 & 25.8 \\
\hline 20LP1GS_5 & Fresh snow over Groomed & 1 & 8.7 & 14.2 & 14.4 & 18.7 & 8.7 & 14.2 & 14.4 & 18.7 \\
\hline 20LP1GS_5 & Fresh snow over Groomed & 2 & 11.4 & 18.3 & 23.7 & 28.3 & 11.4 & 18.3 & 23.7 & 28.3 \\
\hline 20LP1GS_5 & Fresh snow over Groomed & 3 & 8.5 & 16.4 & 21.4 & 22.1 & 8.5 & 16.4 & 21.4 & 22.1 \\
\hline 20LP1GS_5 & Groomed & 1 & 13.3 & 17.8 & 16.2 & 18.5 & 13.3 & 17.8 & 16.2 & 18.5 \\
\hline 20LP1GS_5 & Groomed & 2 & 11.9 & 13.7 & 18.9 & 21.4 & 11.9 & 13.7 & 18.9 & 21.4 \\
\hline 20LP1GS_5 & Groomed & 3 & 16.7 & 21.4 & 26.2 & 26.4 & 16.7 & 21.4 & 26.2 & 26.4 \\
\hline 20LP1GS_6 & Fresh snow over Groomed & 1 & 9.1 & 14.9 & 20.3 & 22.8 & 9.1 & 14.9 & 20.3 & 22.8 \\
\hline 20LP1GS_6 & Fresh snow over Groomed & 2 & 4.6 & 10.5 & 11.6 & 17.8 & 4.6 & 10.5 & 11.6 & 17.8 \\
\hline 20LP1GS_6 & Fresh snow over Groomed & 3 & 7.6 & 18.3 & 22.4 & 21.9 & 7.6 & 18.3 & 22.4 & 21.9 \\
\hline 20LP1GS_6 & Groomed & 1 & 22.6 & 20.3 & 24.4 & 27.3 & 22.6 & 20.3 & 24.4 & 27.3 \\
\hline 20LP1GS_6 & Groomed & 2 & 11.2 & 16.4 & 20.1 & 24.1 & 11.2 & 16.4 & 20.1 & 24.1 \\
\hline 20LP1GS_6 & Groomed & 3 & 14.8 & 14.2 & 19.2 & 23 & 14.8 & 14.2 & 19.2 & 23 \\
\hline 21SWP_1 & Fresh snow over Groomed & 1 & 10.3 & 19.8 & 26.4 & 30.3 & 10.3 & 19.8 & 26.4 & 30.3 \\
\hline 21SWP_1 & Fresh snow over Groomed & 2 & 16.7 & 18.5 & 22.4 & 25.3 & 16.7 & 18.5 & 22.4 & 25.3 \\
\hline 21SWP_1 & Fresh snow over Groomed & 3 & 5.3 & 14.1 & 16.6 & 21 & 5.3 & 14.1 & 16.6 & 21 \\
\hline 21SWP_1 & Groomed & 1 & 20.1 & 22.6 & 26.7 & 29.6 & 20.1 & 22.6 & 26.7 & 29.6 \\
\hline 21SWP_1 & Groomed & 2 & 3.5 & 9.1 & 14.6 & 18.7 & 3.5 & 9.1 & 14.6 & 18.7 \\
\hline 21SWP_1 & Groomed & 3 & 9.9 & 16.2 & 18.2 & 20.7 & 9.9 & 16.2 & 18.2 & 20.7 \\
\hline 21SWP_2 & Fresh snow over Groomed & 1 & 9.1 & 15.3 & 19.4 & 19.6 & 9.1 & 15.3 & 19.4 & 19.6 \\
\hline 21SWP_2 & Fresh snow over Groomed & 2 & 9.2 & 14.6 & 19.1 & 21.6 & 9.2 & 14.6 & 19.1 & 21.6 \\
\hline 21SWP_2 & Fresh snow over Groomed & 3 & 17.4 & 23.5 & 22.1 & 14.8 & 17.4 & 23.5 & 22.1 & 14.8 \\
\hline 21SWP_2 & Groomed & 1 & 20.7 & 25.8 & 28.5 & 33 & 20.7 & 25.8 & 28.5 & 33 \\
\hline 21SWP_2 & Groomed & 2 & 20.1 & 19.4 & 25.3 & 24.4 & 20.1 & 19.4 & 25.3 & 24.4 \\
\hline 21SWP_2 & Groomed & 3 & 13.3 & 20.8 & 21.2 & 26 & 13.3 & 20.8 & 21.2 & 26 \\
\hline 21SWP_3 & Fresh snow over Groomed & 1 & 11.2 & 18.9 & 19.4 & 22.3 & 11.2 & 18.9 & 19.4 & 22.3 \\
\hline 21SWP_3 & Fresh snow over Groomed & 2 & 9.1 & 18.5 & 20.7 & 21.6 & 9.1 & 18.5 & 20.7 & 21.6 \\
\hline 21SWP_3 & Fresh snow over Groomed & 3 & 7.4 & 14.4 & 18.5 & 18.5 & 7.4 & 14.4 & 18.5 & 18.5 \\
\hline 21SWP_3 & Groomed & 1 & 12.1 & 12.6 & 15.3 & 20.7 & 12.1 & 12.6 & 15.3 & 20.7 \\
\hline 21SWP_3 & Groomed & 2 & 7.8 & 7.6 & 12.3 & 16.9 & 7.8 & 7.6 & 12.3 & 16.9 \\
\hline 21SWP_3 & Groomed & 3 & 6 & 9.4 & 11.6 & 16.4 & 6 & 9.4 & 11.6 & 16.4 \\
\hline 21SU1_1 & Groomed & 1 & 8.9 & 14.2 & 15.5 & 19.4 & 8.9 & 14.2 & 15.5 & 19.4 \\
\hline 21SU1_1 & Groomed & 2 & 6.9 & 13.7 & 17.8 & 19.8 & 6.9 & 13.7 & 17.8 & 19.8 \\
\hline 21SU1_1 & Groomed & 3 & 8.3 & 10.1 & 13 & 18.2 & 8.3 & 10.1 & 13 & 18.2 \\
\hline 21SU1_2 & Groomed & 1 & 7.6 & 11.7 & 13.2 & 18 & 7.6 & 11.7 & 13.2 & 18 \\
\hline 21SU1_2 & Groomed & 2 & 7.6 & 9.8 & 12.1 & 15.1 & 7.6 & 9.8 & 12.1 & 15.1 \\
\hline 21SU1_2 & Groomed & 3 & 7.6 & 8.3 & 11.7 & 14.4 & 7.6 & 8.3 & 11.7 & 14.4 \\
\hline 21GPRD_1 & Groomed & 1 & 31.4 & 29.6 & 26 & 27.3 & 31.4 & 29.6 & 26 & 27.3 \\
\hline 21GPRD_1 & Groomed & 2 & 28.2 & 37.4 & 36.4 & 22.4 & 28.2 & 37.4 & 36.4 & 22.4 \\
\hline 21GPRD_1 & Groomed & 3 & 20.7 & 31 & 33.3 & 31.7 & 20.7 & 31 & 33.3 & 31.7 \\
\hline 21SU2_A2 & Groomed & 1 & 10.5 & 17.6 & 11.9 & 16.1 & 10.5 & 17.6 & 11.9 & 16.1 \\
\hline
\end{tabular}


Table D-4 (cont.). Michigan Clegg data.

\begin{tabular}{|c|c|c|c|c|c|c|c|c|c|c|}
\hline \multirow[b]{2}{*}{ Site } & \multirow[b]{2}{*}{ Snow surface } & \multirow[b]{2}{*}{ Test } & \multicolumn{4}{|c|}{0.5 kg Clegg } & \multicolumn{4}{|c|}{$2.25 \mathrm{~kg}$ Clegg } \\
\hline & & & Drop 1 & Drop 2 & Drop 3 & Drop 4 & Drop 1 & Drop 2 & Drop 3 & Drop 4 \\
\hline 21SU2_A2 & Groomed & 2 & 13 & 15.8 & 18.7 & 21.6 & 13 & 15.8 & 18.7 & 21.6 \\
\hline 21SU2_A2 & Groomed & 3 & 8.5 & 13 & 15.1 & 17.8 & 8.5 & 13 & 15.1 & 17.8 \\
\hline 22SU3_1 & Groomed & 1 & 19.8 & 23.9 & 30.8 & 32.6 & 19.8 & 23.9 & 30.8 & 32.6 \\
\hline 22SU3_1 & Groomed & 2 & 12.8 & 22.3 & 28.7 & 33 & 12.8 & 22.3 & 28.7 & 33 \\
\hline 22SU3_1 & Groomed & 3 & 11.7 & 13.3 & 21.7 & 28 & 11.7 & 13.3 & 21.7 & 28 \\
\hline 22SU3_2 & Groomed & 1 & 22.8 & 26 & 31.9 & 38.5 & 22.8 & 26 & 31.9 & 38.5 \\
\hline 22SU3_2 & Groomed & 2 & 16.9 & 22.6 & 25.5 & 29.2 & 16.9 & 22.6 & 25.5 & 29.2 \\
\hline 22SU3_2 & Groomed & 3 & 14.9 & 18.3 & 24.2 & 32.3 & 14.9 & 18.3 & 24.2 & 32.3 \\
\hline 22SU3_3 & Groomed & 1 & 19.6 & 19.4 & 22.4 & 24.4 & 19.6 & 19.4 & 22.4 & 24.4 \\
\hline 22SU3_3 & Groomed & 2 & 21.6 & 25.8 & 32.8 & 39.2 & 21.6 & 25.8 & 32.8 & 39.2 \\
\hline 22SU3_3 & Groomed & 3 & 17.8 & 21.4 & 14.4 & 27.4 & 17.8 & 21.4 & 14.4 & 27.4 \\
\hline 22SU2 & Groomed & 1 & 14.2 & 16.2 & 18.2 & 22.6 & 14.2 & 16.2 & 18.2 & 22.6 \\
\hline 22SU2 & Groomed & 2 & 10.3 & 11.2 & 16 & 19.8 & 10.3 & 11.2 & 16 & 19.8 \\
\hline 22SU2 & Groomed & 3 & 14.1 & 13 & 16.8 & 21 & 14.1 & 13 & 16.8 & 21 \\
\hline 22LP3E & Groomed & 1 & 16.2 & 26.7 & 28.7 & 36.4 & 16.2 & 26.7 & 28.7 & 36.4 \\
\hline 22LP3E & Groomed & 2 & 7.3 & 16.6 & 23.7 & 29.2 & 7.3 & 16.6 & 23.7 & 29.2 \\
\hline 22LP3E & Groomed & 3 & 11.6 & 13.3 & 14.6 & 20.3 & 11.6 & 13.3 & 14.6 & 20.3 \\
\hline 22IR_S & Groomed & 1 & 34.8 & 32.3 & 35.1 & 36.4 & 34.8 & 32.3 & 35.1 & 36.4 \\
\hline 22IR_S & Groomed & 2 & 29.9 & 32.1 & 33.2 & & 29.9 & 32.1 & 33.2 & \\
\hline 22IR_S & Groomed & 3 & 30.5 & 30.1 & 34.9 & 34 & 30.5 & 30.1 & 34.9 & 34 \\
\hline 22STAB_S & Groomed & 1 & 26 & 30.1 & 26.9 & 28.7 & 26 & 30.1 & 26.9 & 28.7 \\
\hline 22STAB_S & Groomed & 2 & 34.8 & 44.8 & 46.2 & 46.7 & 34.8 & 44.8 & 46.2 & 46.7 \\
\hline 22STAB_S & Groomed & 3 & 33.2 & 30.8 & 29.4 & 27.1 & 33.2 & 30.8 & 29.4 & 27.1 \\
\hline 22STAB_S & Rutted groomed & 1 & 27.3 & 31.5 & 30.7 & 23.9 & 27.3 & 31.5 & 30.7 & 23.9 \\
\hline 22STAB_S & Rutted groomed & 2 & 30.1 & 37.3 & 34.2 & 35.8 & 30.1 & 37.3 & 34.2 & 35.8 \\
\hline 22STAB_S & Rutted groomed & 3 & 36 & 43.2 & 48.7 & 51.9 & 36 & 43.2 & 48.7 & 51.9 \\
\hline 22VDA2 & Groomed & 1 & 13.7 & 15.8 & 17.6 & 16.2 & 13.7 & 15.8 & 17.6 & 16.2 \\
\hline 22VDA2 & Groomed & 2 & 17.1 & 21.7 & 21.7 & 25.1 & 17.1 & 21.7 & 21.7 & 25.1 \\
\hline 22VDA2 & Groomed & 3 & 22.1 & 28 & 39.6 & 37.3 & 22.1 & 28 & 39.6 & 37.3 \\
\hline $22900 C$ & Rutted groomed & 1 & 32.3 & 32.4 & 37.4 & 43.2 & 32.3 & 32.4 & 37.4 & 43.2 \\
\hline $22900 C$ & Rutted groomed & 2 & 28.2 & 35.7 & 38 & 43.2 & 28.2 & 35.7 & 38 & 43.2 \\
\hline $22900 C$ & Rutted groomed & 3 & 35.8 & 34.4 & 38 & 43 & 35.8 & 34.4 & 38 & 43 \\
\hline $22300 \mathrm{C}$ & Rutted groomed & 1 & 14.2 & 23.3 & 19.2 & 20.5 & 14.2 & 23.3 & 19.2 & 20.5 \\
\hline $22300 \mathrm{C}$ & Rutted groomed & 2 & 11.6 & 16.7 & 13.2 & 18.9 & 11.6 & 16.7 & 13.2 & 18.9 \\
\hline $22300 \mathrm{C}$ & Rutted groomed & 3 & 13.7 & 15.7 & 16 & 18 & 13.7 & 15.7 & 16 & 18 \\
\hline 22LP4 & Groomed & 1 & 25.8 & 24.2 & 26.9 & 34.2 & 25.8 & 24.2 & 26.9 & 34.2 \\
\hline 22LP4 & Groomed & 2 & 21 & 26.4 & 32.4 & 36.2 & 21 & 26.4 & 32.4 & 36.2 \\
\hline 22LP4 & Groomed & 3 & 20.3 & 25.5 & 33.2 & 37.4 & 20.3 & 25.5 & 33.2 & 37.4 \\
\hline 22LP3NW & Groomed & 1 & 19.1 & 21.6 & 26.9 & 34.4 & 19.1 & 21.6 & 26.9 & 34.4 \\
\hline 22LP3NW & Groomed & 2 & 10.7 & 21.7 & 29 & 31.4 & 10.7 & 21.7 & 29 & 31.4 \\
\hline 22LP3NW & Groomed & 3 & 0 & 16.7 & 20.8 & 17.8 & 0 & 16.7 & 20.8 & 17.8 \\
\hline
\end{tabular}


Table D-5. Montana Rammsonde data.

\begin{tabular}{|c|c|c|c|c|c|c|c|c|c|}
\hline \multicolumn{2}{|c|}{ 27TWYSVS } & \multicolumn{2}{|c|}{ 27TWYSVS } & \multicolumn{2}{|c|}{ 28MLPW } & \multicolumn{2}{|c|}{ 28MLPW } & \multicolumn{2}{|c|}{ 30MLPN } \\
\hline $\begin{array}{c}\text { Depth } \\
\text { (cm) }\end{array}$ & Index & $\begin{array}{c}\text { Depth } \\
\text { (cm) }\end{array}$ & Index & $\begin{array}{c}\text { Depth } \\
\text { (cm) }\end{array}$ & Index & $\begin{array}{c}\text { Depth } \\
\text { (cm) }\end{array}$ & Index & $\begin{array}{c}\text { Depth } \\
\text { (cm) }\end{array}$ & Index \\
\hline 19 & & 17 & & 47.5 & 3 & 55 & & 23 & \\
\hline 57 & 2 & 55 & 2 & 48 & 5 & 56 & 5 & 23 & \\
\hline \multirow[t]{16}{*}{57} & & & & 49 & 6 & 57 & 10 & 24 & 10 \\
\hline & & & & 51 & 4 & 58 & 18 & 25 & 10 \\
\hline & & & & 53 & 4 & 59 & 18 & 25 & \\
\hline & & & & 53.5 & 10 & 60 & 34 & 27 & 10 \\
\hline & & & & 54 & 18 & 60.5 & 49 & 27.5 & 34 \\
\hline & & & & 54.5 & 18 & 61 & 65 & 28 & 49 \\
\hline & & & & 55 & 34 & 61.5 & 23 & 29 & 18 \\
\hline & & & & 55 & & & & 31 & 11 \\
\hline & & & & & & & & 35 & 8 \\
\hline & & & & & & & & 40 & 6 \\
\hline & & & & & & & & 42 & 6 \\
\hline & & & & & & & & 43 & 7 \\
\hline & & & & & & & & 44 & 12 \\
\hline & & & & & & & & 46 & 12 \\
\hline & & & & & & & & 47 & 12 \\
\hline & & & & & & & & 48 & 12 \\
\hline
\end{tabular}


Table D-6. Michigan Rammsonde data.

\begin{tabular}{|c|c|c|c|c|c|c|c|c|c|}
\hline \multicolumn{2}{|c|}{ 19SU2_A } & \multicolumn{2}{c|}{ 19SU2_B } & \multicolumn{2}{c|}{ 19SU2_C } & \multicolumn{2}{c|}{ 19SU2_D } & \multicolumn{2}{c|}{ 19SU2_E } \\
\hline $\begin{array}{c}\text { Depth } \\
\text { (cm) }\end{array}$ & Index & $\begin{array}{c}\text { Depth } \\
\text { (cm) }\end{array}$ & Index & $\begin{array}{c}\text { Depth } \\
\text { (cm) }\end{array}$ & Index & $\begin{array}{c}\text { Depth } \\
\text { (cm) }\end{array}$ & $\begin{array}{c}\text { Depth } \\
\text { Index }\end{array}$ & Index \\
\hline-2 & 119 & 19 & 119 & 0 & 119 & 0 & 119 & 1 & 119 \\
\hline 0 & 119 & 34 & 213 & 1 & 213 & 0.5 & 400 & 2 & 213 \\
\hline 0 & & & & 2 & 400 & 3 & 325 & 2 & NA \\
\hline 1 & 400 & 34 & 213 & 2 & NA & 4 & 775 & 3 & 213 \\
\hline 1.5 & 1150 & 124 & 775 & 4 & 400 & 5.5 & 410 & 4 & 400 \\
\hline 2 & 1525 & 244 & 1525 & 5 & 775 & 7 & 310 & 6 & 160 \\
\hline 4 & 1431 & 184 & 460 & 6 & 310 & 9 & 235 & 7 & 310 \\
\hline 7 & 510 & 184 & 460 & 7 & 460 & 10 & 460 & 8.5 & 210 \\
\hline 10 & 510 & 124 & 194 & 8 & 460 & 11 & 287 & 10 & 210 \\
\hline 16 & 162 & 244 & 381 & 8 & NA & 12 & 287 & 11 & 194 \\
\hline 18 & 241 & 124 & 194 & 10 & 310 & 13 & 287 & 12 & 194 \\
\hline 19 & 475 & 124 & 194 & 11 & 381 & 14 & 287 & 13 & 194 \\
\hline 20 & 475 & 124 & 194 & 12 & 381 & 15 & 287 & 14 & 194 \\
\hline & & 124 & 194 & 13 & 381 & 17 & 147 & 15 & 194 \\
\hline & & & & 15 & 241 & & & 16 & 194 \\
\hline & & & & 16 & 45 & & & 17 & 21 \\
\hline & & & & 17 & 475 & & & 18 & 194 \\
\hline
\end{tabular}


Table D-7. Additional Michigan Rammsonde data.

\begin{tabular}{|c|c|c|c|c|c|c|c|c|c|c|c|}
\hline \multicolumn{2}{|c|}{ 19SU2_F } & \multicolumn{2}{|c|}{ 22SU3VS } & \multicolumn{2}{|c|}{ 21SWP_1 } & \multicolumn{2}{|c|}{ 21SWP_2 } & \multicolumn{2}{|c|}{ 21SWP_3 } & \multicolumn{2}{|c|}{ 20LP1GS_4 } \\
\hline $\begin{array}{l}\text { Depth } \\
\text { (cm) }\end{array}$ & Index & $\begin{array}{l}\text { Depth } \\
\text { (cm) }\end{array}$ & Index & $\begin{array}{l}\text { Depth } \\
\text { (cm) }\end{array}$ & Index & $\begin{array}{l}\text { Depth } \\
\text { (cm) }\end{array}$ & Index & $\begin{array}{l}\text { Depth } \\
\text { (cm) }\end{array}$ & Index & $\begin{array}{l}\text { Depth } \\
\text { (cm) }\end{array}$ & Index \\
\hline 2 & 119 & 29.5 & 7 & 34 & 213 & -1.5 & 213 & 2 & 119 & -1.5 & 150 \\
\hline 3 & 213 & 30 & 6 & 34 & 213 & -1 & 400 & 3 & 400 & 0 & 275 \\
\hline 3 & NA & 30 & NA & 64 & 400 & 0 & 400 & 4 & 400 & 1 & 400 \\
\hline 4 & 775 & 30 & NA & 124 & 775 & 1 & 400 & 4.5 & 775 & 2 & 400 \\
\hline 5 & 775 & 30 & NA & 184 & 1150 & 1.25 & 1525 & 4.75 & 2275 & 2 & NA \\
\hline 6 & 310 & 30 & NA & 184 & 1150 & 2 & 1525 & 6 & 370 & 2.5 & 1900 \\
\hline 6.5 & 610 & 31 & 26 & 244 & 1525 & 3 & 1150 & 7 & 460 & 4 & 1275 \\
\hline 7 & 910 & 31 & NA & 124 & 775 & 4 & 775 & 8 & 910 & 5 & 2837 \\
\hline 8.5 & 310 & 31.5 & 34 & 244 & 1525 & 5 & 1525 & 9 & 760 & 6 & 760 \\
\hline 10 & 310 & 32 & 34 & 304 & 1900 & 6 & 610 & 10 & 1135 & 7 & 760 \\
\hline 11 & 287 & 32.5 & 34 & 304 & 1900 & 7 & 1135 & & & 8 & 760 \\
\hline 13 & 194 & 33 & 42 & 304 & 760 & & & & & 9 & 760 \\
\hline 15 & 194 & 33.5 & 50 & 455 & 1135 & & & & & 10 & 760 \\
\hline 16 & 381 & 34 & 50 & & & & & & & 11.5 & 319 \\
\hline 19 & 131 & 49 & 4 & & & & & & & 13 & 319 \\
\hline 22 & 28 & 50 & 3 & & & & & & & 14 & 45 \\
\hline 24 & 194 & 52 & 14 & & & & & & & 15 & 475 \\
\hline \multirow[t]{20}{*}{25} & 381 & 54.5 & 21 & & & & & & & & \\
\hline & & 56 & 23 & & & & & & & & \\
\hline & & 57.5 & 13 & & & & & & & & \\
\hline & & 59 & 13 & & & & & & & & \\
\hline & & 60 & 18 & & & & & & & & \\
\hline & & 61 & 18 & & & & & & & & \\
\hline & & 62 & 18 & & & & & & & & \\
\hline & & 63 & 18 & & & & & & & & \\
\hline & & 64 & 18 & & & & & & & & \\
\hline & & 65.5 & 13 & & & & & & & & \\
\hline & & 67.5 & 10 & & & & & & & & \\
\hline & & 69 & 13 & & & & & & & & \\
\hline & & 70 & 18 & & & & & & & & \\
\hline & & 71 & 18 & & & & & & & & \\
\hline & & 72 & 26 & & & & & & & & \\
\hline & & 74 & 14 & & & & & & & & \\
\hline & & 75 & 26 & & & & & & & & \\
\hline & & 77 & 14 & & & & & & & & \\
\hline & & 78.5 & 18 & & & & & & & & \\
\hline & & 86 & 6 & & & & & & & & \\
\hline
\end{tabular}


Table D-8. Montana Russian Snow Penetrometer data.

\begin{tabular}{|c|c|c|c|c|c|}
\hline \multicolumn{2}{|c|}{ 25RWY0 } & \multicolumn{2}{c|}{ 25RWY50 } & \multicolumn{2}{c|}{ 25RWY100 } \\
\hline $\begin{array}{c}\text { Depth } \\
(\mathrm{mm})\end{array}$ & Index & $\begin{array}{c}\text { Depth } \\
(\mathrm{mm})\end{array}$ & Index & $\begin{array}{c}\text { Depth } \\
(\mathrm{mm})\end{array}$ & Index \\
\hline 20 & 2 & 30 & 59 & 15 & 2 \\
\hline 70 & 19 & 50 & 44 & 25 & 87 \\
\hline 90 & 44 & 70 & 87 & 40 & 59 \\
\hline 100 & 87 & 75 & 514 & 60 & 44 \\
\hline 105 & 1708 & 90 & 229 & 75 & 59 \\
\hline 115 & 599 & 100 & 428 & 90 & 59 \\
\hline & & 110 & 428 & 100 & 87 \\
\hline & & 115 & 855 & 105 & 855 \\
\hline
\end{tabular}

Table D-9. Michigan Russian Snow Penetrometer data.

\begin{tabular}{|c|c|c|c|c|c|c|c|c|c|c|c|c|c|c|}
\hline \multicolumn{2}{|c|}{ 19SU2_A } & \multicolumn{2}{|c|}{ 19SU2_B } & \multicolumn{2}{c|}{ 19SU2_C } & \multicolumn{2}{c|}{ 19SU2_D } & \multicolumn{2}{|c|}{ 19SU2EE } & \multicolumn{2}{|c|}{ 19SU2_F } & \multicolumn{2}{c|}{ 20LP1WG_1 } \\
\hline $\begin{array}{c}\text { Depth } \\
(\mathbf{m m})\end{array}$ & Index & $\begin{array}{c}\text { Depth } \\
(\mathbf{m m})\end{array}$ & Index & $\begin{array}{c}\text { Depth } \\
(\mathbf{m m})\end{array}$ & Index & $\begin{array}{c}\text { Depth } \\
(\mathbf{m m})\end{array}$ & $\begin{array}{c}\text { Depth } \\
\text { Index }\end{array}$ & $\begin{array}{c}\text { Depth } \\
(\mathbf{m m})\end{array}$ & $\begin{array}{c}\text { Depth } \\
\text { Index }\end{array}$ & $\begin{array}{c}\text { Index } \\
\text { (mm) }\end{array}$ & Index \\
\hline 20 & 3 & 50 & 21 & 45 & 45 & 20 & 3 & 20 & 3 & 20 & 3 & 20 & 3 \\
\hline 23 & 297 & 60 & 18 & 60 & 60 & 55 & 19 & 55 & 19 & 50 & 21 & 45 & 23 \\
\hline 40 & 55 & 75 & 62 & 75 & 75 & 70 & 62 & 75 & 47 & 55 & 179 & 55 & 91 \\
\hline 49 & 101 & 105 & 33 & 85 & 85 & 80 & 91 & 100 & 38 & 100 & 23 & 60 & 179 \\
\hline 70 & 45 & 125 & 47 & 105 & 105 & 95 & 62 & 120 & 47 & 125 & 38 & 70 & 91 \\
\hline 75 & 179 & 150 & 38 & 120 & 120 & 110 & 62 & 140 & 47 & 150 & 38 & 80 & 179 \\
\hline 90 & 62 & 175 & 38 & 130 & 130 & 130 & 47 & 155 & 62 & 170 & 47 & 90 & 91 \\
\hline 115 & 38 & 200 & 38 & 150 & 150 & 170 & 25 & 175 & 47 & 200 & 33 & 105 & 62 \\
\hline 130 & 62 & 225 & 38 & 165 & 165 & 200 & 33 & 200 & 38 & 230 & 33 & 115 & 91 \\
\hline 140 & 91 & 240 & 62 & 180 & 180 & 225 & 38 & 220 & 47 & 250 & 47 & 140 & 38 \\
\hline 155 & 62 & 250 & 91 & 205 & 205 & & & 230 & 91 & 265 & 62 & 165 & 38 \\
\hline 175 & 47 & & & 225 & 225 & & & 255 & 38 & 270 & 179 & 180 & 62 \\
\hline 200 & 38 & & & 235 & 235 & & & 260 & 179 & & & 195 & 62 \\
\hline 225 & 38 & & & & & & & & & & & 215 & 47 \\
\hline 230 & 179 & & & & & & & & & & & 250 & 28 \\
\hline 232 & 443 & & & & & & & & & & & 280 & 33 \\
\hline 235 & 297 & & & & & & & & & & & 285 & 179 \\
\hline 236 & 883 & & & & & & & & & & & & \\
\hline 240 & 443 & & & & & & & & & & & & \\
\hline 251 & 163 & & & & & & & & & & & & \\
\hline 260 & 492 & & & & & & & & & & & & \\
\hline 275 & 297 & & & & & & & & & & & & \\
\hline 280 & 883 & & & & & & & & & & & & \\
\hline 290 & 443 & & & & & & & & & & & & \\
\hline 315 & 179 & & & & & & & & & & & & \\
\hline 320 & 883 & & & & & & & & & & & \\
\hline
\end{tabular}


Table D-10. Additional Michigan Russian Snow Penetrometer data.

\begin{tabular}{|c|c|c|c|c|c|c|c|c|c|c|c|c|c|c|c|c|c|c|c|}
\hline \multicolumn{2}{|c|}{ 20LP1WG_2 } & \multicolumn{2}{|c|}{ 20LP1WG_3 } & \multicolumn{2}{|c|}{ 20LP1GS_4 } & \multicolumn{2}{|c|}{ 20LP1GS_5 } & \multicolumn{2}{|c|}{ 20LP1GS_6 } & \multicolumn{2}{|c|}{ 21SWP_1 } & \multicolumn{2}{|c|}{ 21SWP_2 } & \multicolumn{2}{|c|}{ 21SWP_3 } & \multicolumn{2}{|c|}{ 21SU1_1 } & \multicolumn{2}{|c|}{ 21SU1_2 } \\
\hline $\begin{array}{l}\text { Depth } \\
(\mathrm{mm})\end{array}$ & Index & $\begin{array}{c}\text { Depth } \\
(\mathrm{mm})\end{array}$ & index & $\begin{array}{c}\text { Depth } \\
(\mathrm{mm})\end{array}$ & Index & $\begin{array}{c}\text { Depth } \\
(\mathrm{mm})\end{array}$ & Index & $\begin{array}{l}\text { Depth } \\
(\mathrm{mm})\end{array}$ & Index & $\begin{array}{c}\text { Depth } \\
(\mathrm{mm})\end{array}$ & Index & $\begin{array}{l}\text { Depth } \\
(\mathrm{mm})\end{array}$ & Index & $\begin{array}{l}\text { Depth } \\
(\mathrm{mm})\end{array}$ & Index & $\begin{array}{c}\text { Depth } \\
(\mathrm{mm})\end{array}$ & Index & $\begin{array}{l}\text { Depth } \\
(\mathrm{mm})\end{array}$ & Index \\
\hline 30 & 33 & 10 & 3 & 20 & 3 & 25 & 38 & 35 & 28 & 20 & 47 & 25 & 38 & 25 & 38 & 40 & 25 & 20 & 47 \\
\hline 50 & 47 & 25 & 38 & 50 & 21 & 40 & 62 & 40 & 179 & 30 & 91 & 40 & 62 & 40 & 62 & 50 & 91 & 30 & 91 \\
\hline 60 & 91 & 45 & 47 & 55 & 179 & 50 & 91 & 50 & 91 & 40 & 91 & 50 & 91 & 50 & 91 & 55 & 179 & 75 & 23 \\
\hline 75 & 62 & 50 & 179 & 100 & 23 & 55 & 179 & 55 & 179 & 50 & 91 & 55 & 179 & 65 & 62 & 75 & 47 & 85 & 91 \\
\hline 95 & 47 & 60 & 91 & 125 & 38 & 60 & 179 & 60 & 179 & 55 & 179 & 60 & 355 & 70 & 179 & 80 & 179 & 100 & 62 \\
\hline 105 & 91 & 75 & 62 & 150 & 38 & 70 & 91 & 70 & 91 & 60 & 179 & 65 & 355 & 75 & 179 & 100 & 47 & 120 & 47 \\
\hline 125 & 47 & 80 & 179 & 170 & 47 & 75 & 179 & 75 & 179 & 65 & 179 & 70 & 355 & 80 & 179 & 120 & 47 & 135 & 62 \\
\hline 135 & 91 & 85 & 179 & 200 & 33 & 80 & 179 & 100 & 38 & 75 & 91 & 80 & 179 & 85 & 179 & 145 & 38 & 145 & 91 \\
\hline 160 & 38 & 90 & 179 & 230 & 33 & 90 & 91 & 125 & 38 & 85 & 91 & 100 & 47 & 90 & 179 & 160 & 62 & 155 & 91 \\
\hline 170 & 91 & 100 & 91 & 250 & 47 & 100 & 91 & 150 & 38 & 100 & 62 & 120 & 47 & 100 & 91 & 190 & 33 & 170 & 62 \\
\hline 175 & 179 & 115 & 62 & 265 & 62 & 120 & 47 & 170 & 47 & 105 & 179 & 150 & 33 & 110 & 91 & 215 & 38 & 185 & 62 \\
\hline 180 & 179 & 130 & 62 & 270 & 179 & 145 & 38 & 185 & 62 & 120 & 62 & 180 & 33 & 115 & 179 & 230 & 62 & 205 & 47 \\
\hline 185 & 179 & 155 & 38 & & & 165 & 47 & 205 & 47 & 125 & 179 & & & 125 & 91 & 235 & 179 & 230 & 38 \\
\hline 190 & 179 & 170 & 62 & & & 180 & 62 & 230 & 38 & 135 & 91 & & & 140 & 62 & 240 & 179 & 240 & 91 \\
\hline 195 & 179 & 180 & 91 & & & 205 & 38 & 250 & 47 & 145 & 91 & & & 165 & 38 & & & 245 & 179 \\
\hline 200 & 179 & 190 & 91 & & & 220 & 62 & 255 & 179 & 150 & 179 & & & 170 & 179 & & & 246 & 883 \\
\hline 205 & 179 & 205 & 62 & & & 235 & 62 & & & 160 & 91 & & & 175 & 179 & & & & \\
\hline & & 225 & 47 & & & 250 & 62 & & & 165 & 179 & & & & & & & & \\
\hline & & 235 & 91 & & & & & & & 170 & 179 & & & & & & & & \\
\hline & & 237 & 443 & & & & & & & & & & & & & & & & \\
\hline
\end{tabular}


Table D-11. Further Michigan Russian Snow Penetrometer data.

\begin{tabular}{|c|c|c|c|c|c|c|c|}
\hline \multicolumn{2}{|c|}{ 21SU1_3 } & \multicolumn{2}{c|}{ 22SU3_1 } & \multicolumn{2}{c|}{ 22SU3_2 } & \multicolumn{2}{c|}{ 22SU3_3 } \\
\hline $\begin{array}{c}\text { Depth } \\
(\mathrm{mm})\end{array}$ & Index & $\begin{array}{c}\text { Depth } \\
(\mathrm{mm})\end{array}$ & Index & $\begin{array}{c}\text { Depth } \\
(\mathrm{mm})\end{array}$ & $\begin{array}{c}\text { Depth } \\
\text { Index }\end{array}$ & Index \\
\hline 40 & 25 & 25 & 74 & 25 & 38 & 20 & 47 \\
\hline 50 & 91 & 40 & 121 & 30 & 355 & 25 & 179 \\
\hline 60 & 91 & 50 & 91 & 35 & 179 & 30 & 179 \\
\hline 75 & 62 & 60 & 179 & 50 & 62 & 35 & 179 \\
\hline 110 & 28 & 80 & 91 & 60 & 91 & 45 & 91 \\
\hline 135 & 38 & 110 & 33 & 80 & 47 & 50 & 179 \\
\hline 150 & 62 & 125 & 62 & 110 & 33 & 55 & 179 \\
\hline 155 & 179 & 150 & 38 & 125 & 62 & 75 & 47 \\
\hline 165 & 91 & 170 & 47 & 130 & 179 & 95 & 47 \\
\hline 175 & 91 & 175 & 179 & 140 & 91 & 115 & 47 \\
\hline 180 & 179 & 180 & 179 & 155 & 62 & 140 & 38 \\
\hline 200 & 47 & 185 & 179 & 175 & 47 & 155 & 62 \\
\hline 215 & 62 & 190 & 179 & 200 & 38 & 185 & 33 \\
\hline 230 & 62 & 195 & 179 & 215 & 62 & 190 & 179 \\
\hline 240 & 91 & 200 & 179 & 225 & 91 & 195 & 355 \\
\hline 248 & 113 & & & 230 & 179 & & \\
\hline 250 & 443 & & & & & & \\
\hline
\end{tabular}




\section{Appendix E: Comparison of Snow Moisture and Density Measurement Techniques (Student Intern Poster)}




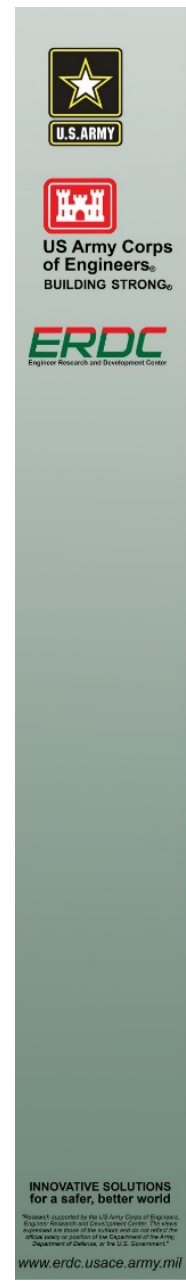

\section{Methods for Measuring Snow Moisture and Density}

Mary Feyrer, Jackie Balch, Bruce Elder, and Sally Shoop

Objective

Determine the accuracy and reliability of the Finnish Snowfork by comparing the density and moisture

data it collects to moisture data from Denoth

Compare different Denoth meters

sed by CRREL to each other in order to ensure that they are

Comparison of Moisture and Density

Measurement Methods from the Field

Moisture and density profiles were measured in snowpits usin
the Finnish Fork and LaChappelle cutters to measure density

Conclusion

Author contact information: Mary Feyrer / mcf85@cornell.edu
Aurm.mil

The Finnish fork is a reliable tool for measuring the moisture content of snow

Denoths can sometimes prod

particular in dry snow

Wensistently reports densities that are

lower than the recorded sample density

Finnish fork densities are generally $r$ but become inaccurate in wet snow
but

Statistics

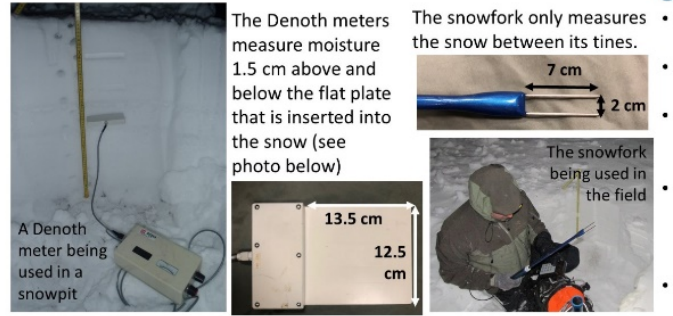

Sample density and snowfork density are not statistically equivalent (T-Test, $p=0.00043$ Sample density is on average $0.0368 \mathrm{~g} / \mathrm{cc}$ greater than the snowfork density the denoth are not statistically equivalent Wilcoxon rank test, $p=0.001$ )

Denoth moisture values are on average higher than the Finnish fork $0.236 \%$ Vol higher when nuss's and Sally's values are rounded to 0 equivalent (Wilcoxon rank test, $\mathrm{p}=0.73$ )

Average Finnish Fork Density and Moisture Compared to Average Sample Density and Average Denoth

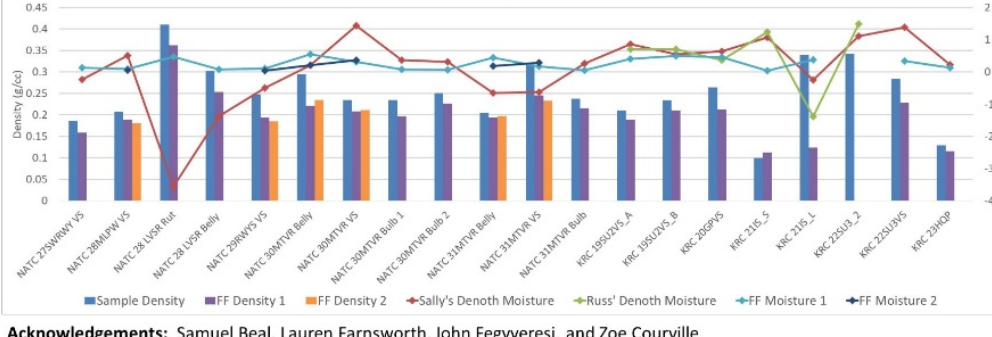

Acknowledgements: Samuel Beal, Lauren Farnsworth, John Fegyveresi, and Zoe Courville

Funding was provided by ERDC Military Engineering Program on Remote Assessment of Infrastructure for Ensured Maneuver
Denoth and Snowfork Comparison Test in Melting Snow

Objective: Test the calibration of CRREL's five Denoths by comparing them to each other and to the Finnish Snowfork at varying moisture levels

Setup: Denoth and snowfork sensors were tested in a snowbox of sieved snow which was placed outside and le Daled: Tempert

Deters, Moisture and Density, Moisture from 5 Denoth Sample Density, Data from 3 De Roo Snow Sensors 3 MircoCT Scans

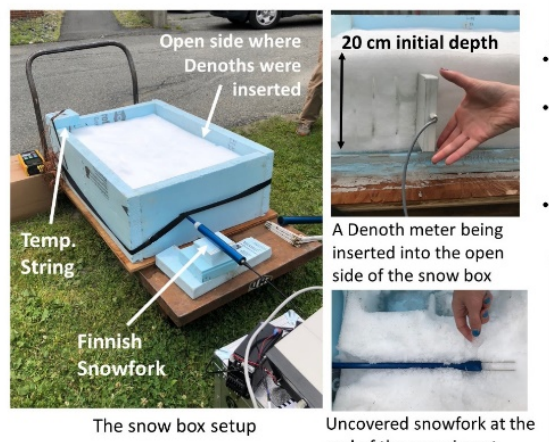

The snow box setup end of the experiment

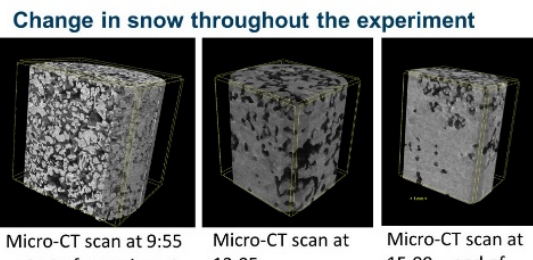

Micro-CT scan at 9:55

Micro-cr

Micro-CT scan
15:00- end of $15: 00-$ end
experiment
Results of Comparison Test

A Comparison of Moisture Contents Measured

The spike in snowfork

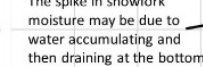

at the bottom
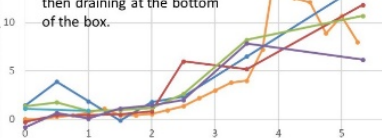

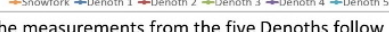
each other relatively closely

- The snowfork moisture my lower than the Denoths', most likely due to the snowfork being position in the middle of the box and the Denoth measurements being taken at the edge The last measurement with Denoth 4 was taken in different location in the box the other Denoths

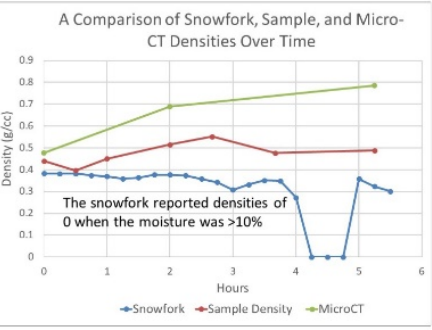

Densities measured by the Micro-CT are - significantly greater hen the sample densities - Densities measured by the Snowfork are The accuracy of the Snowfork density measurements went down considerably in wet snow conditions. 


\section{Appendix F: WV2 and WV3 Data Concurrent with Michigan Field Campaign}

Figure F-1. WorldView-2 reflectance spectra averaged by study area.

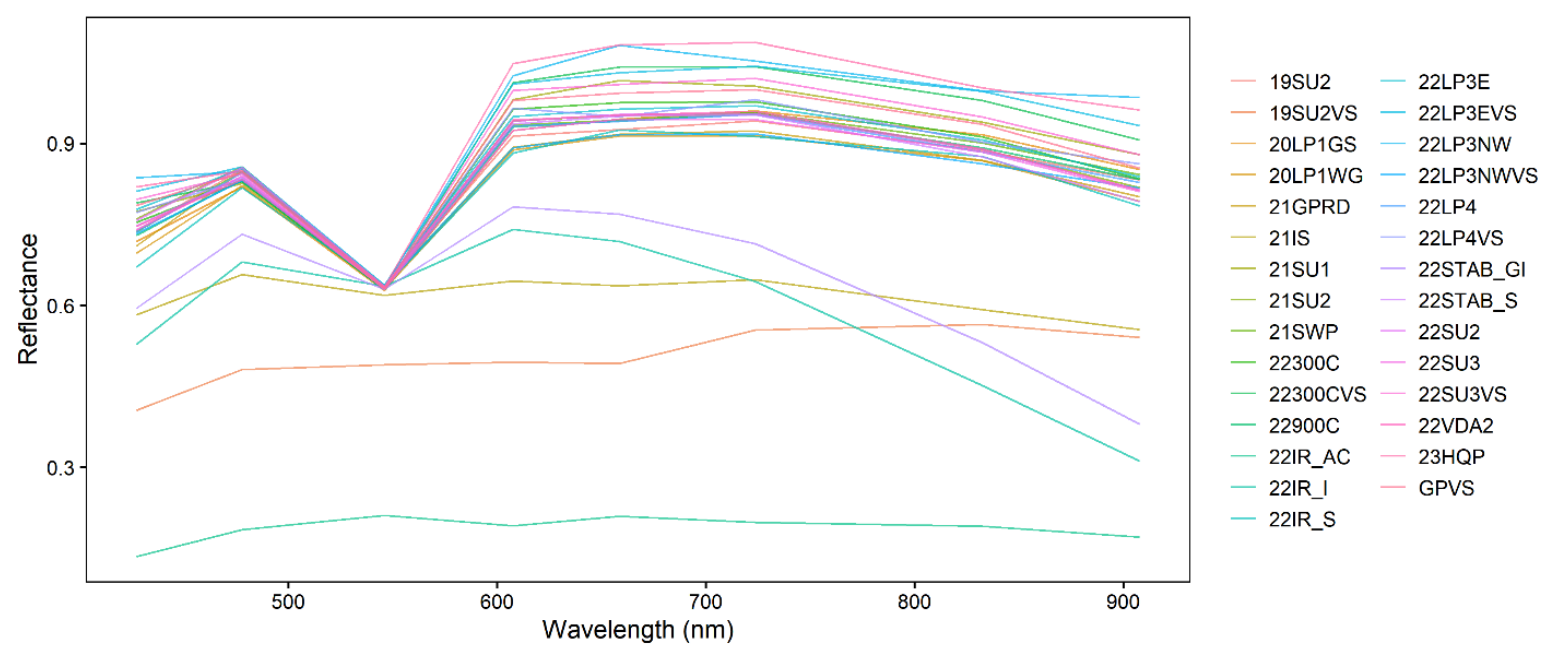

Figure F-2. WorldView-2 reflectance spectra averaged by subgrade. 
Figure F-3. WorldView-3 reflectance spectra averaged by study area.

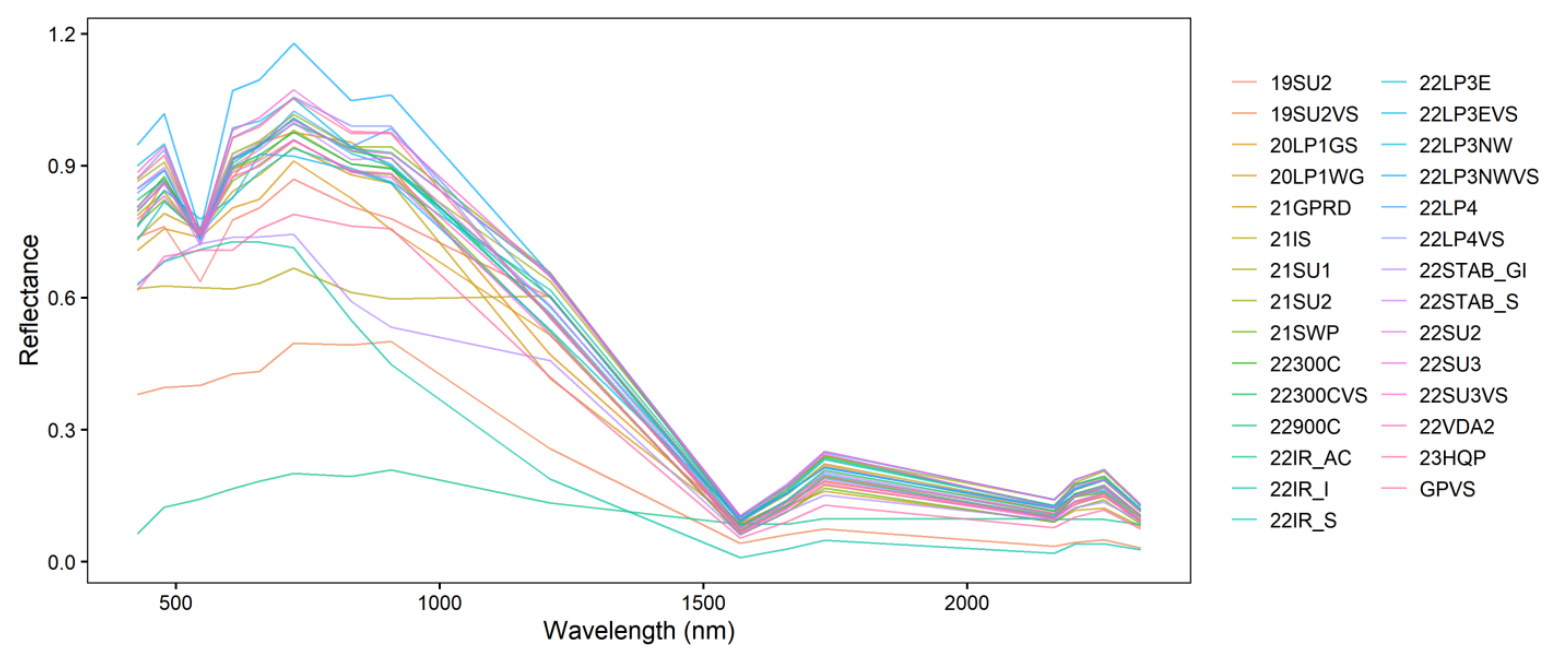

Figure F-4. WorldView-3 reflectance spectra averaged by snow surface type.

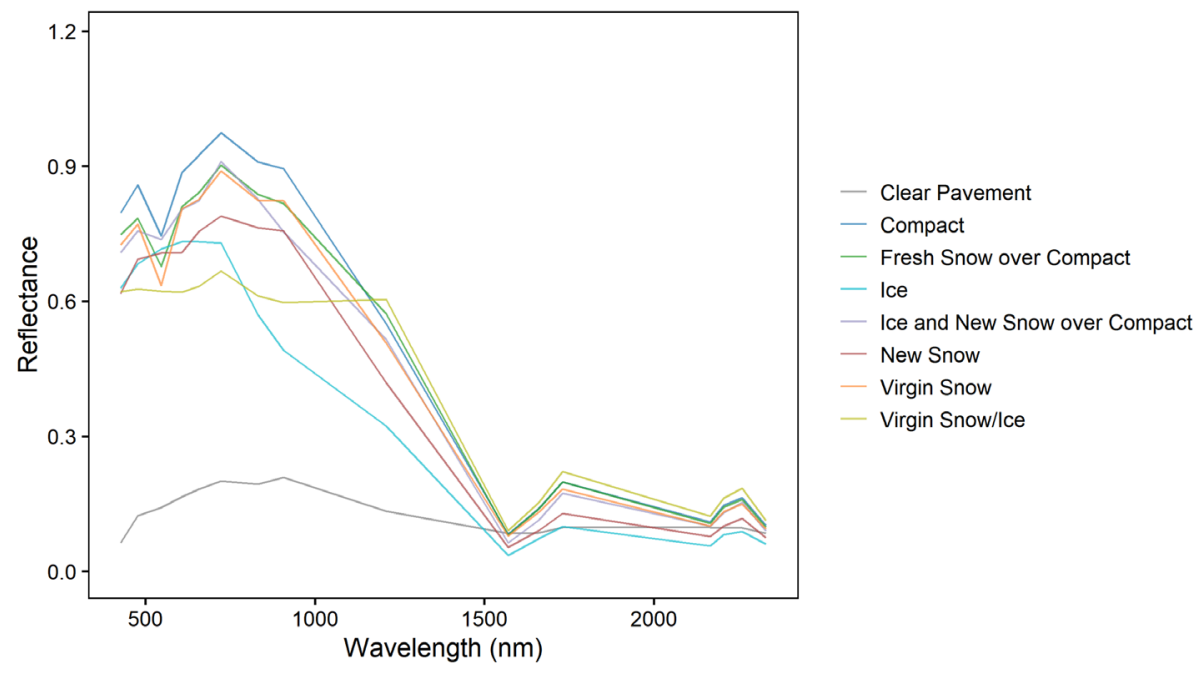

Figure F-5. WorldView-3 reflectance spectra averaged by subgrade. 
Table F-1. Spearman correlations between WorldView-2 multispectral bands and snow mechanical measurements (Michigan). The $p$-values are indicated as $*<0.05, * *<0.01$, and $* * *<0.001$.

\begin{tabular}{|c|c|c|c|c|c|c|c|c|}
\hline \multirow{3}{*}{$\begin{array}{l}\text { Mechanical } \\
\text { Measurement }\end{array}$} & \multicolumn{8}{|c|}{ Spearman's Rho } \\
\hline & \multicolumn{8}{|c|}{ WorldView-2 Band } \\
\hline & MS1 & MS2 & MS3 & MS4 & MS5 & MS6 & MS7 & MS8 \\
\hline CTI & $-0.453 * *$ & -0.211 & 0.136 & $-0.382 *$ & -0.311 & -0.342 & -0.237 & -0.251 \\
\hline Ram 0-15 cm & 0.133 & 0.133 & -0.183 & 0.517 & 0.617 & 0.600 & 0.533 & 0.650 \\
\hline Ram $15+\mathrm{cm}$ & -0.029 & 0.714 & 0.486 & 0.086 & 0.086 & 0.029 & 0.029 & 0.029 \\
\hline Ram Full & -0.176 & 0.248 & 0.115 & 0.103 & 0.176 & 0.164 & 0.115 & 0.200 \\
\hline RSP 0-15 cm & 0.014 & 0.020 & 0.028 & 0.141 & 0.058 & 0.084 & 0.061 & 0.086 \\
\hline RSP $15+\mathrm{cm}$ & 0.204 & 0.045 & -0.044 & 0.220 & 0.195 & 0.130 & 0.068 & -0.081 \\
\hline RSP Full & 0.179 & 0.157 & 0.056 & 0.316 & 0.247 & 0.235 & 0.170 & 0.077 \\
\hline $0.5 \mathrm{~kg}$ Clegg & 0.193 & 0.142 & 0.039 & 0.027 & -0.142 & 0.011 & -0.161 & -0.204 \\
\hline 2.25 kg Clegg & -0.213 & -0.101 & 0.011 & -0.194 & -0.218 & -0.223 & -0.317 & -0.329 \\
\hline Yamaha & $-0.711 * *$ & $-0.683 *$ & -0.449 & $-0.667 *$ & $-0.623 *$ & $-0.631 *$ & $-0.601 *$ & $-0.634 *$ \\
\hline Shear Vane & -0.036 & -0.649 & $-0.714 *$ & -0.429 & -0.429 & -0.571 & -0.571 & -0.714 \\
\hline CBR & 0.189 & 0.291 & 0.273 & 0.154 & 0.238 & 0.210 & 0.112 & 0.112 \\
\hline LWD LL1 Average & 0.293 & 0.015 & -0.017 & $0.321 *$ & $0.307 *$ & 0.120 & -0.006 & -0.127 \\
\hline LWD LL2 Average & 0.253 & 0.034 & 0.020 & 0.267 & 0.245 & 0.055 & -0.078 & -0.186 \\
\hline LWD LL3 Average & 0.317 & 0.088 & 0.026 & 0.255 & 0.245 & 0.040 & -0.044 & -0.138 \\
\hline LWD LL4 Average & $0.408^{*}$ & 0.156 & 0.093 & $0.364 *$ & 0.338 & 0.145 & 0.055 & -0.034 \\
\hline $\begin{array}{l}\text { LWD LL1 } \\
\text { Representative }\end{array}$ & 0.275 & 0.021 & -0.022 & 0.291 & 0.265 & 0.102 & -0.036 & -0.103 \\
\hline $\begin{array}{l}\text { LWD LL2 } \\
\text { Representative }\end{array}$ & 0.263 & 0.010 & -0.056 & 0.267 & 0.244 & 0.075 & -0.058 & -0.127 \\
\hline $\begin{array}{l}\text { LWD LL3 } \\
\text { Representative }\end{array}$ & 0.358 & 0.114 & 0.050 & 0.307 & 0.295 & 0.099 & 0.026 & -0.036 \\
\hline $\begin{array}{l}\text { LWD LL4 } \\
\text { Representative }\end{array}$ & 0.353 & 0.069 & -0.030 & 0.299 & 0.281 & 0.114 & 0.024 & -0.026 \\
\hline Density $0-5 \mathrm{~cm}$ & 0.430 & 0.467 & 0.236 & 0.430 & 0.321 & 0.430 & 0.345 & 0.406 \\
\hline Density Average & 0.167 & 0.119 & -0.500 & 0.190 & 0.190 & 0.167 & 0.238 & 0.238 \\
\hline Snow Depth & $0.444 * *$ & 0.245 & -0.080 & $0.426 * *$ & $0.402 *$ & $0.428 * *$ & $0.424 * *$ & $0.461 * *$ \\
\hline Air Temp & $0.462 *$ & $0.356 *$ & 0.058 & $0.527 * *$ & $0.418 *$ & $0.578 * *$ & $0.515 * *$ & $0.608 * * *$ \\
\hline Snow Temp & -0.119 & $-0.417 *$ & -0.086 & -0.032 & -0.188 & 0.014 & -0.046 & 0.075 \\
\hline
\end{tabular}


Figure F-6. Plots of significant $(p<0.01)$ Spearman correlations between WorldView-2 multispectral bands (MS1-MS8) and snow strength measurements, with linear regression models (Michigan data set).
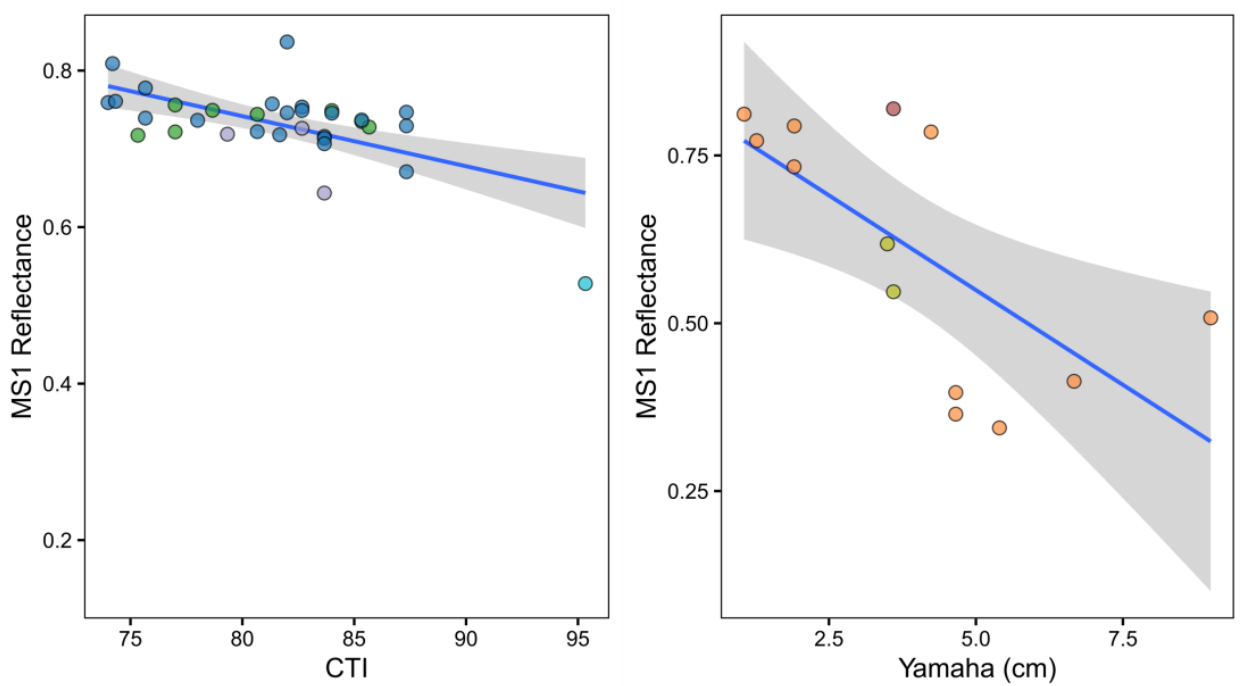

- Clear Pavement

- Compact

- Fresh Snow over Compact

O Ice

- Ice and New Snow over Compact

- New Snow

- Virgin Snow

- Virgin Snow/lce

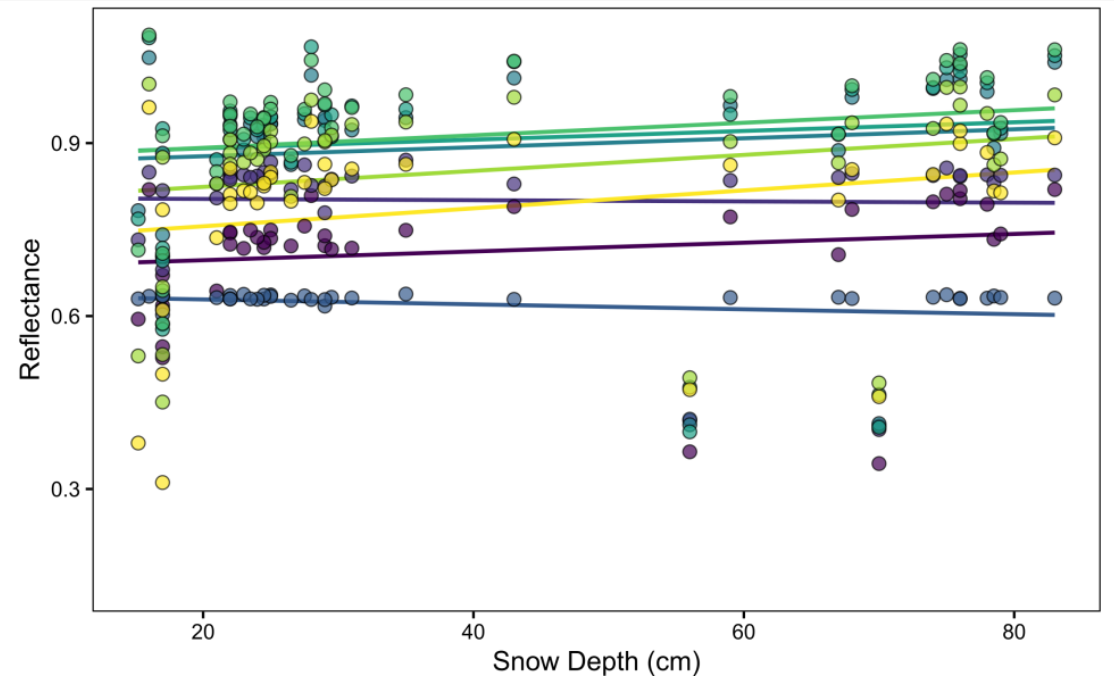

- MS1

- MS2

- MS3

- MS4

- MS5

- MS6

- $\quad$ MS7

O MS8 


\section{Appendix G: Surface-Condition Photos and Michigan Cloud-Cover Photos for Field Spectrometer (ASD) Data Collection}

Photos G-1 through G-6 depict examples of the surfaces at the ASD measurement points. The five general surfaces sampled were asphalt concrete, groomed snow, ice, groomed snow with ruts and tracks, and virgin snow, as plotted in Figure 39 for the Michigan sites. ASD testing in Montana was limited due to weather and other factors.

Figure G-1. Montana ice lane (Montana point 28IL).

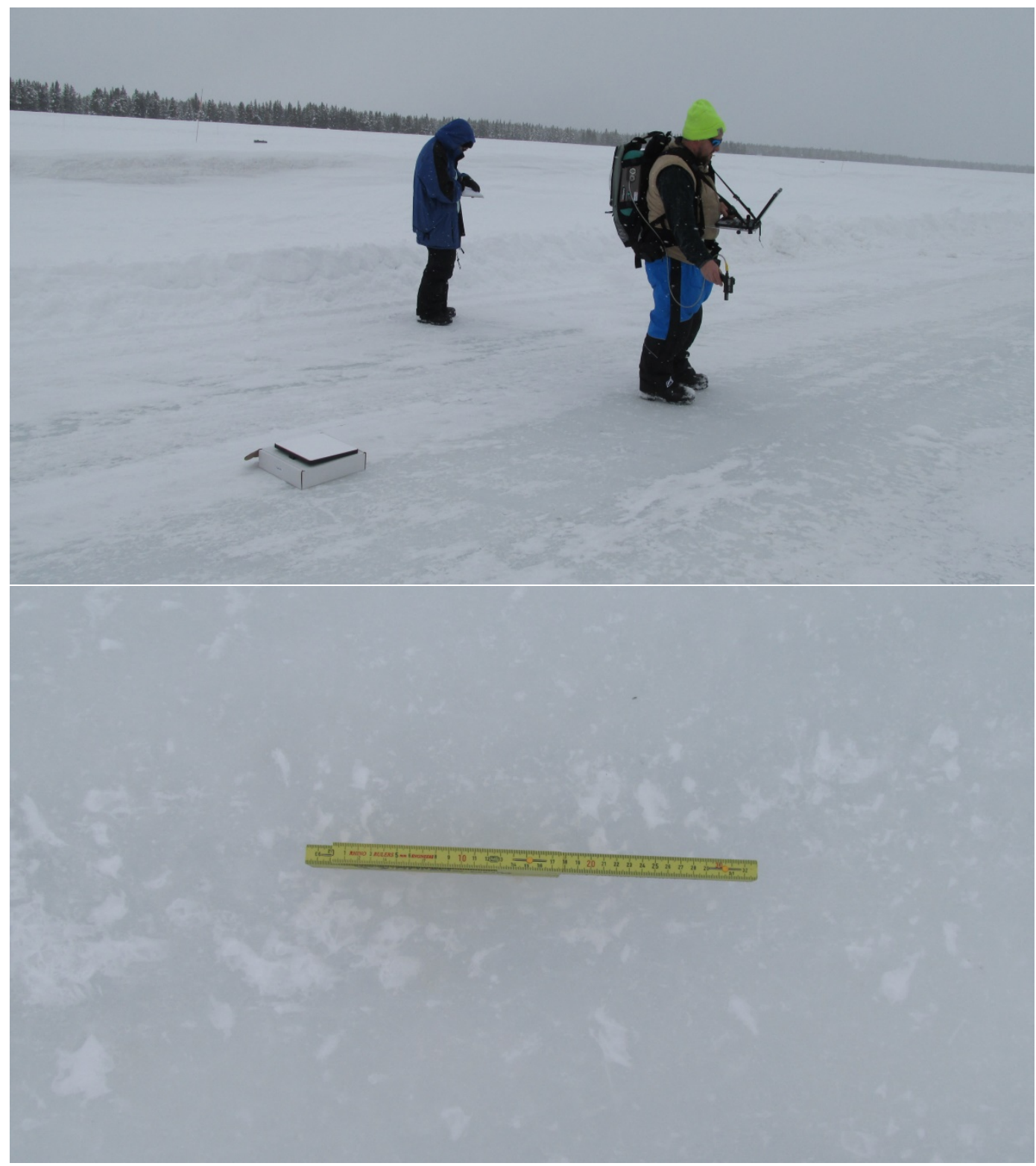


Figure G-2. Asphalt concrete pavement at Ice Rink (Michigan point 22IR_AC) both wet and dry conditions.

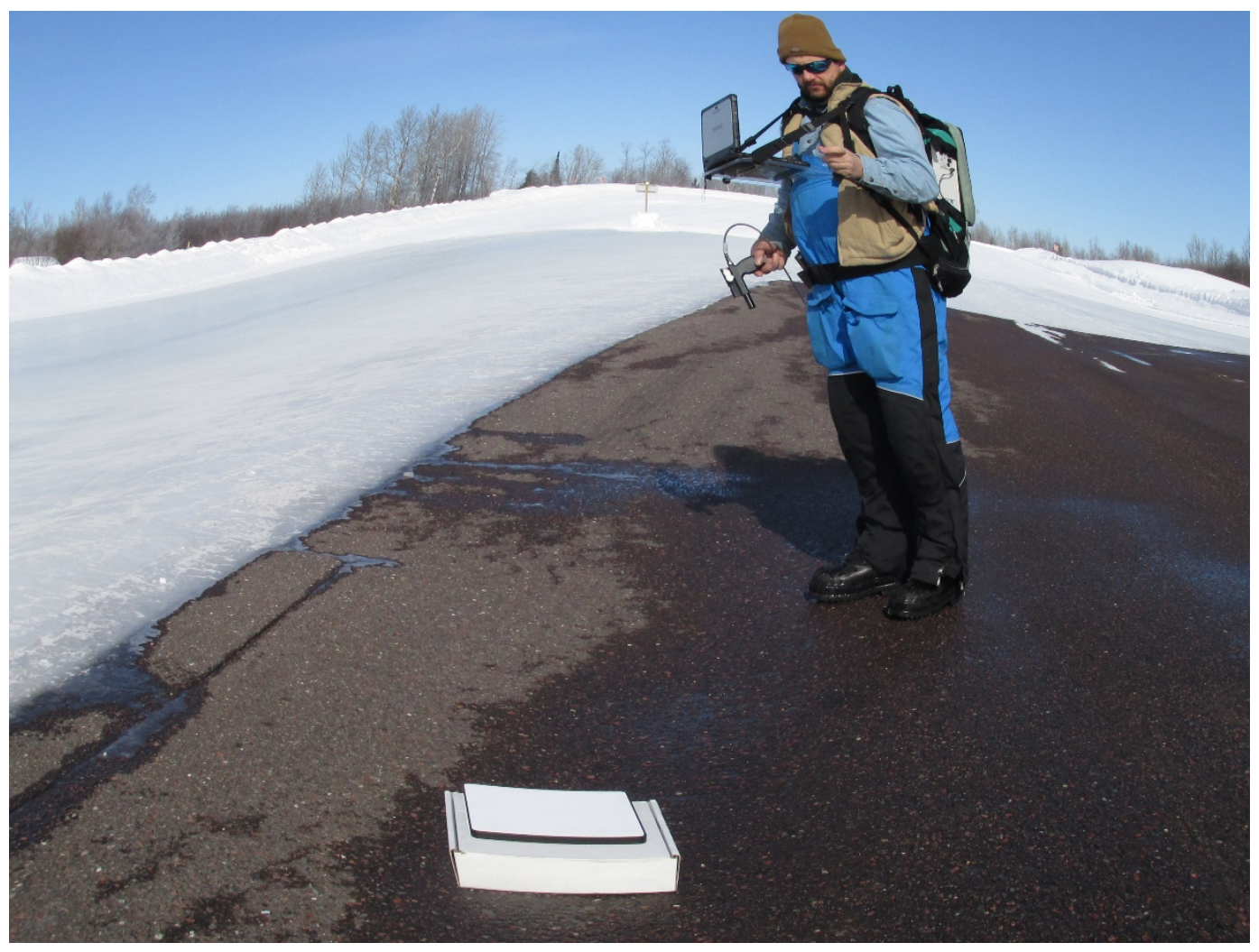


Figure G-3. Michigan groomed snow points 22SU3 (top) and 22SU2 (bottom).
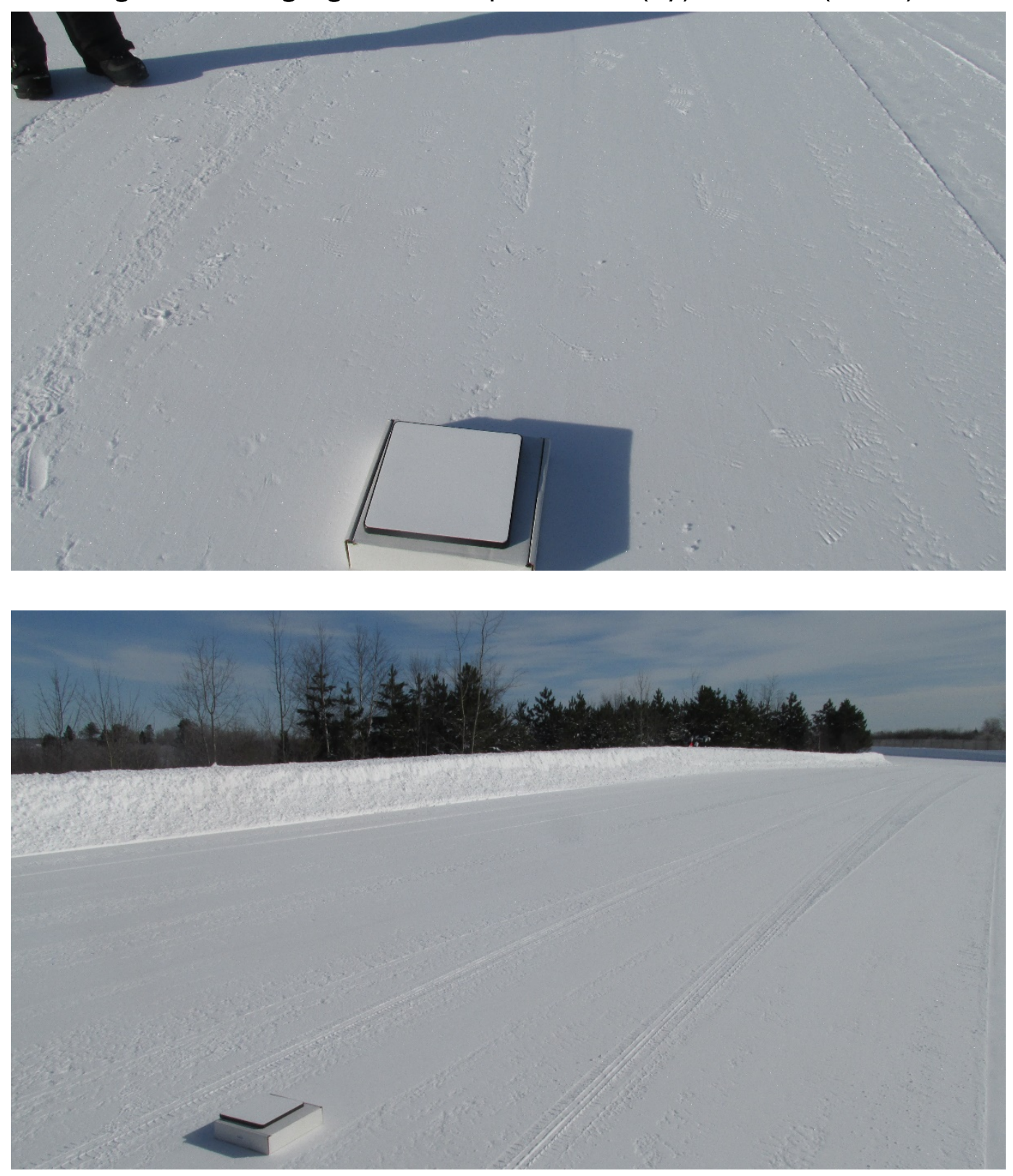
Figure G-4. Michigan smooth ice surface point 22IR_I (top) and grooved ice surface point 22STAB_Gl (bottom).
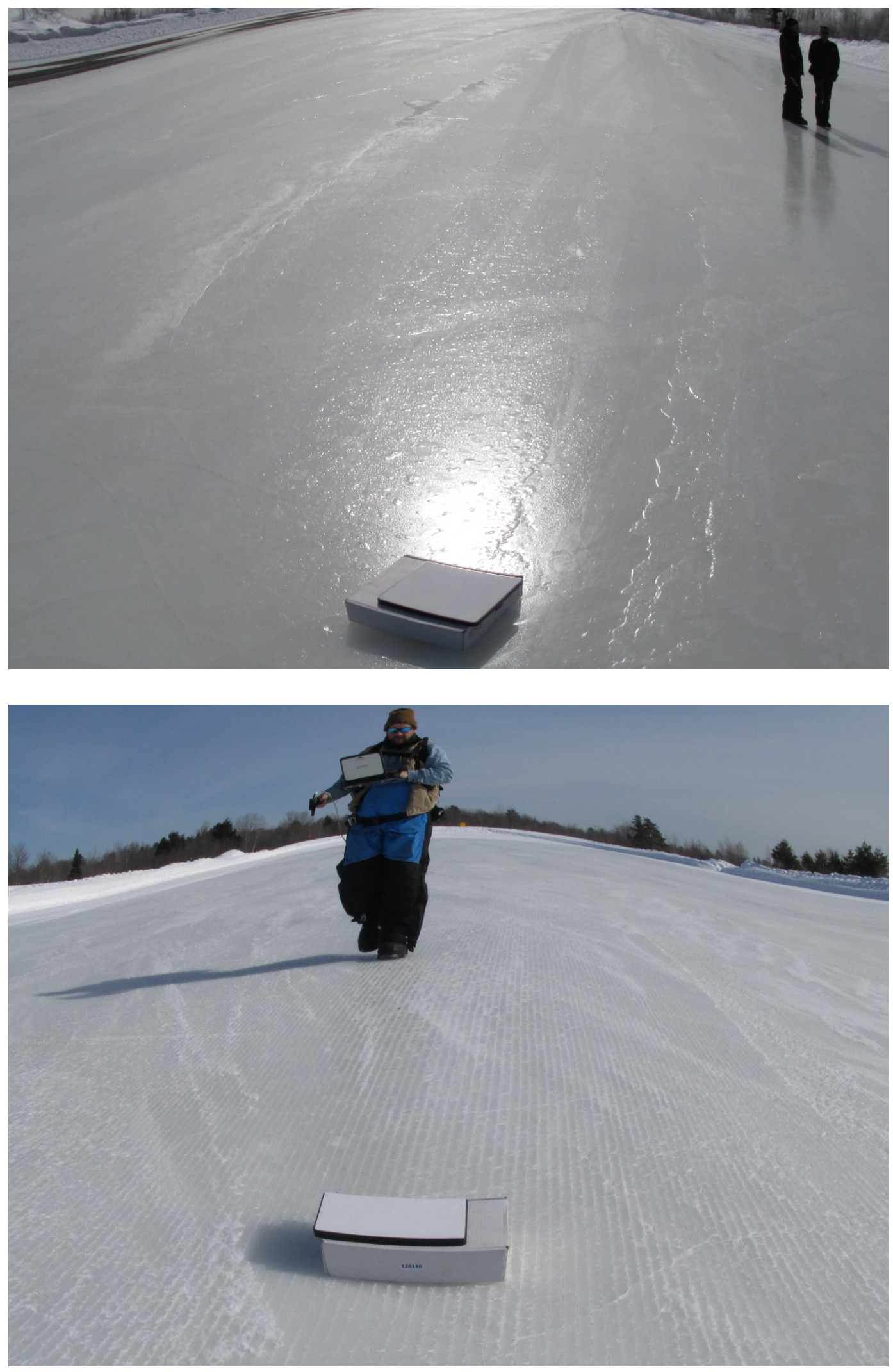
Figure G-5. Michigan rutted snow surface point $22900 \mathrm{C}$ (top) and tracked snow surface point 22LP3NW (bottom).
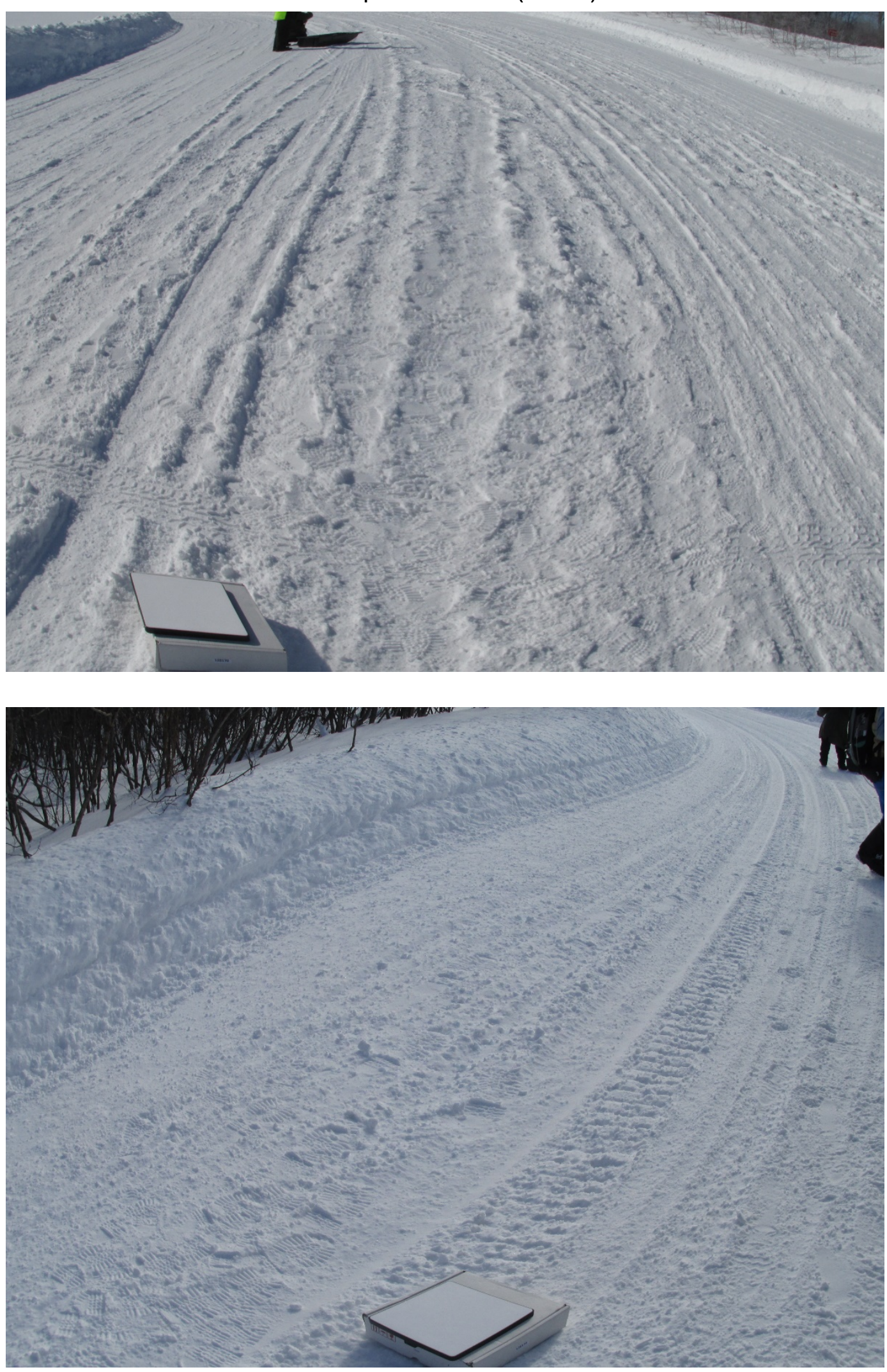
Figure G-6. Michigan virgin snow points 22SU3VS (top) and 22300CVS (bottom).
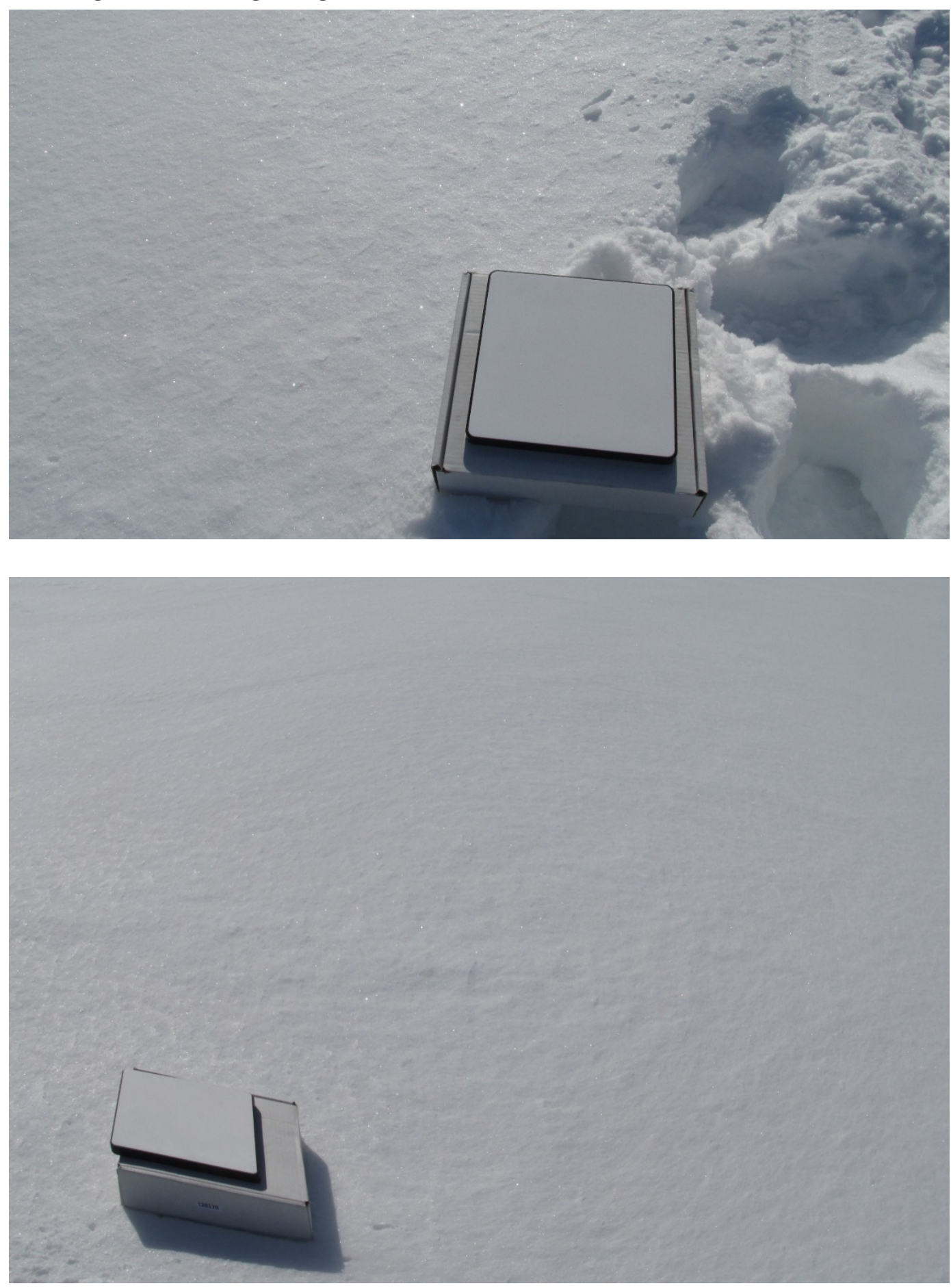
Photos G-7 through G-9 depict the changing cloud cover during the ASD testing on 22 February 2018 in Michigan.

Figure G-7. Cirrostratus cloud cover at the beginning of ASD testing (9:43 local time).

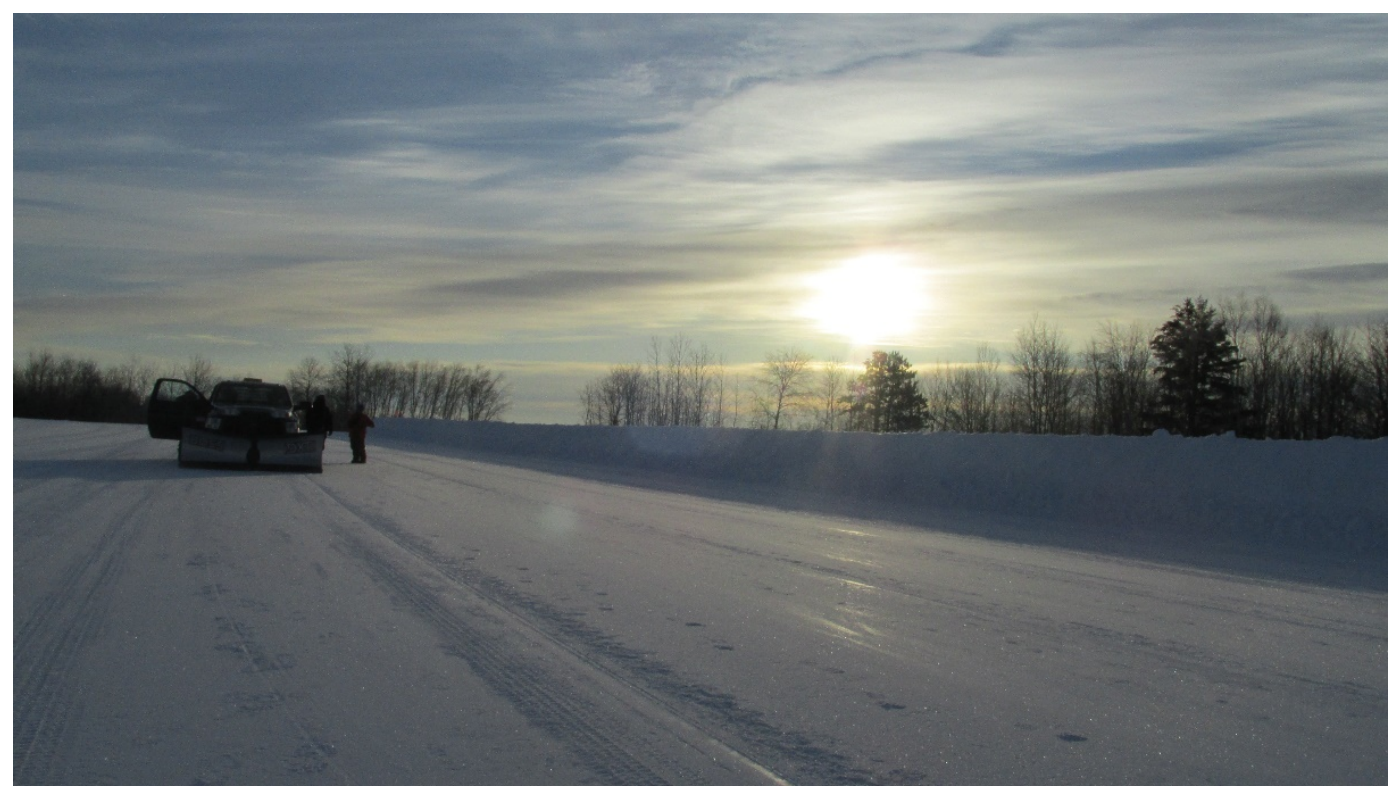

Figure G-8. Cirrostratus and altostratus cloud cover at noon during ASD testing.

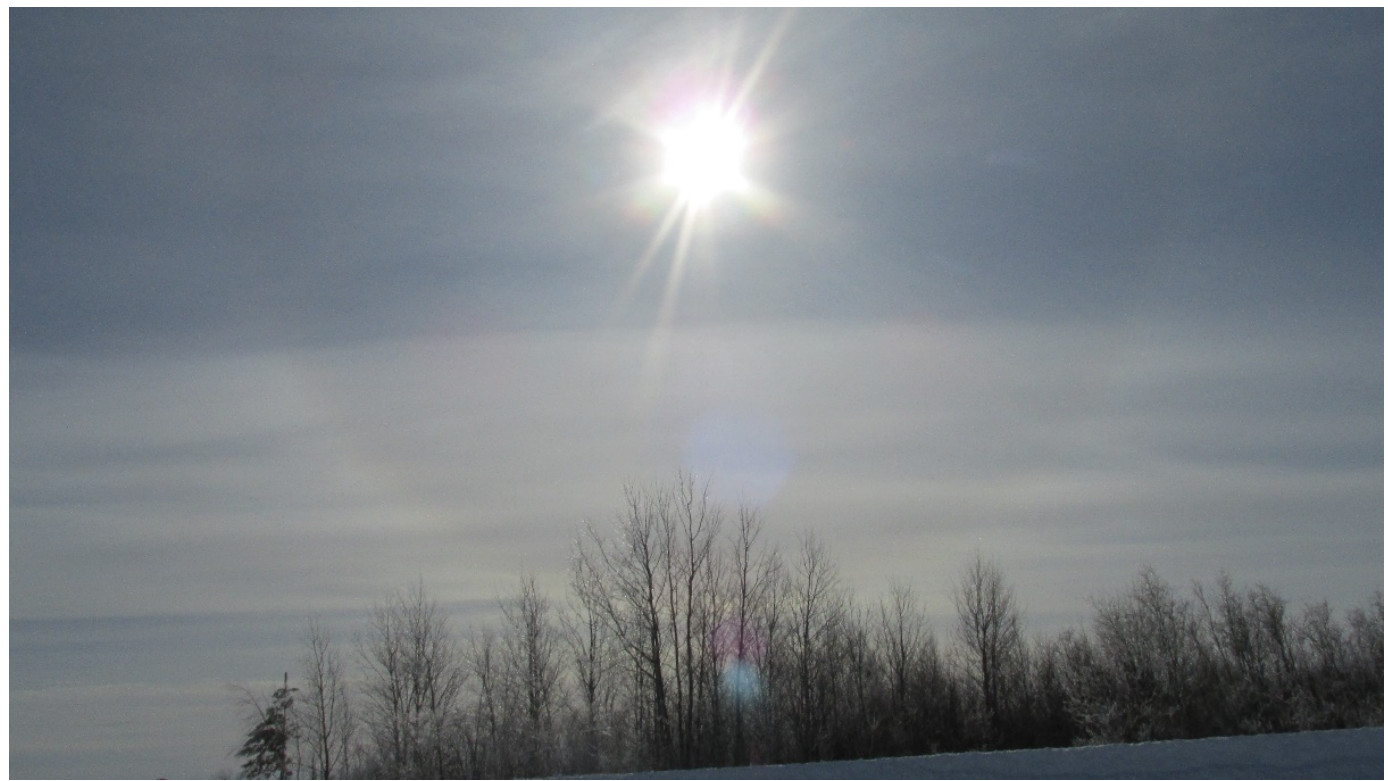


Figure G-9. Altocumulus cloud cover at the end ASD testing ( 16:30 local time). 


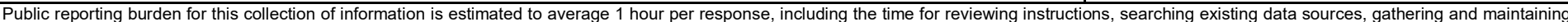

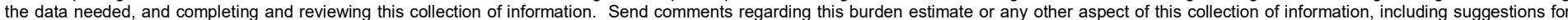

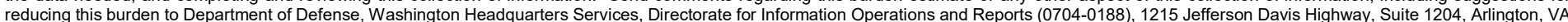

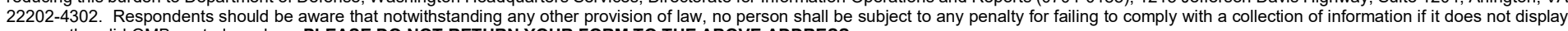
a currently valid OMB control number. PLEASE DO NOT RETURN YOUR FORM TO THE ABOVE ADDRESS.
1. REPORT DATE (DD-MM-YYYY)
2. REPORT TYPE
August 2019
Technical Report/Final

\section{TITLE AND SUBTITLE}

Assessment of Field Methods for Measuring Mechanical Properties of Snow

3. DATES COVERED (From - To)

\section{5a. CONTRACT NUMBER}

5b. GRANT NUMBER

5c. PROGRAM ELEMENT NUMBER

\section{AUTHOR(S)}

Sally A. Shoop, Wendy L. Wieder, Bruce C. Elder, Samuel A. Beal, and Elias J. Deeb

\section{5d. PROJECT NUMBER}

$465395 \& 471941$

5e. TASK NUMBER

5f. WORK UNIT NUMBER

\section{PERFORMING ORGANIZATION NAME(S) AND ADDRESS(ES)}

8. PERFORMING ORGANIZATION REPORT NUMBER

U.S. Army Engineer Research and Development Center (ERDC)

Cold Regions Research and Engineering Laboratory (CRREL)

ERDC/CRREL TR-19-17

72 Lyme Road

Hanover, NH 03755-1290

\section{SPONSORING / MONITORING AGENCY NAME(S) AND ADDRESS(ES)}

Assistant Secretary of the Army for Acquisition, Logistics, and Technology

103 Army Pentagon

Washington, DC 20314-1000

10. SPONSOR/MONITOR'S ACRONYM(S)

ASA(ALT)

11. SPONSOR/MONITOR'S REPORT NUMBER(S)

\section{DISTRIBUTION / AVAILABILITY STATEMENT}

Approved for public release; distribution is unlimited.

\section{SUPPLEMENTARY NOTES}

ERDC 6.2 Boreal Aspects of Ensured Maneuver (BAEM)

\section{ABSTRACT}

Winter climates present a variety of surfaces that challenge vehicle mobility. Surfaces range from soft, virgin snow, to groomed snow and ice. This study evaluated the capabilities of various testing devices to measure the mechanical properties of winter surfaces. Concurrent satellite imagery supplemented in situ physical testing. The goals were (1) to find tests that most practically evaluate these winter surfaces for vehicle mobility and (2) to determine if imagery analysis correlates with mechanical properties, thus potentially allowing remote assessment of snow physical and mechanical characteristics.

The test methods were typically useful for either virgin snow or groomed snow; no method worked well on all surfaces. Correlations between test devices were generally poor, but there were some important trends identified between (1) tests that measure the nearsurface snow strength, (2) tests best suited for stronger snow, (3) the Clegg Impact Hammers and California Bearing Ratio, and (4) the optical imagery and surface drop cones. This study provides a rich dataset for assessing the current state of the art and future research needs for measurement and remote assessment of snow mechanical properties for vehicle mobility prediction.

\section{SUBJECT TERMS}

Bearing capacity, Mechanical properties, Remote sensing, Snow, Snow mechanics, Snow--Testing, Strength, Trafficability, Vehicle mobility

\section{SECURITY CLASSIFICATION OF:}

\section{a. REPORT}

Unclassified

\section{b. ABSTRACT}

Unclassified

\section{c. THIS PAGE}

Unclassified
17. LIMITATION OF ABSTRACT

SAR
18. NUMBER OF PAGES

148 19a. NAME OF RESPONSIBLE PERSON

19b. TELEPHONE NUMBER (include area code) 